

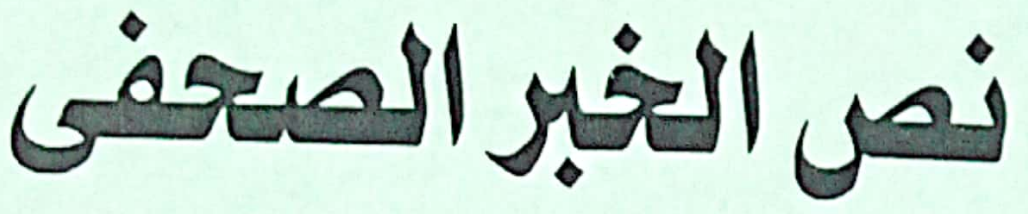 \\ دراسة في ضوء نحو النص
}

\author{
כكتور \\ ربيع عبلد السلام عبل السلام خلف \\ الأستاذ المساعد - قسم علم اللغة \\ كلية دار العلوم- جامهة الفيوم
}




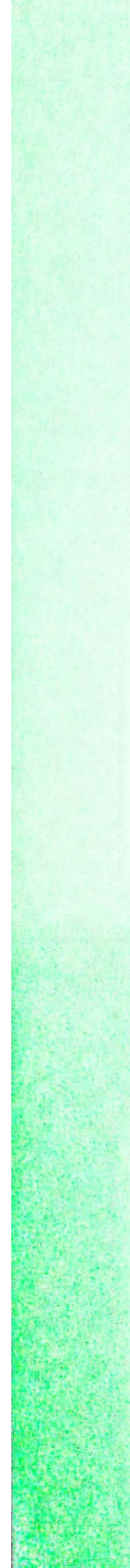


1- التعريف بلغة الصحافة و النص الصحفي:

تعد وظيفةً الاتصال بالجماهير و القراء الوظيفة الأساسية لوســائل الإعــلام

المكتبة و المسمو عة و المرئية، وتهذف - من ور اء هذا الاتصال تزويدهم بالحقـائق

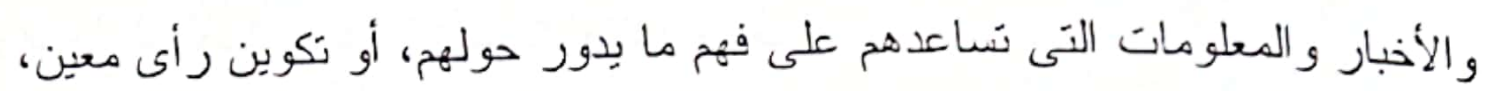
أو اتخاذ موقف محدد تجاه موضو ع من الموضو عات أو مشكلة من المشكلات. و عملية الاتصال هذه تَم من خلال عناصر ثناثثة هى:

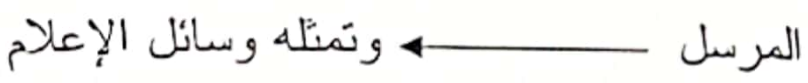
وتمثله الجماهير و القز اء المستقبل وهى الحقائق و الأخبار و المعلومات الرسالة

و اللغة بوصفها هى أداة الاتصسال فلا يمكن تصور وسائل الإعلام المختلفــة دون لغنَ تستخدمها لتوصبل رسالتها إلى المتلقين.

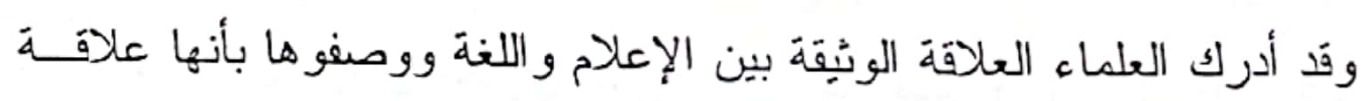
عضوية؛ حيث إن اللغنة بالنسبة للإعلام بمثابة التربة الخصبة التـى ينمــو فيهـا، و المجال الذى يمارس فيه نشاطه وينقل عبره الأفكار (1). اللغة إذن هى المرتكز الذى يعتمد عليه الإعلام في أداء رسالته ووظيفتـه،

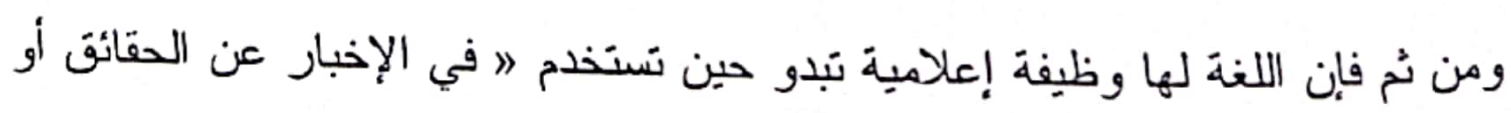
أحداث معينة أو عن نوع من المعرفة أو في شرح معين أو تقديم تقرير عن موضوع إعلئ

(1) انظر هادى نهر: اللسانية والاعلام التأثير والتأثر صVY-rی. 
معين. كالتقارير و النشر ات الإخبارية. والمعلومات العلمية المنتلفـة، والمعلومسان

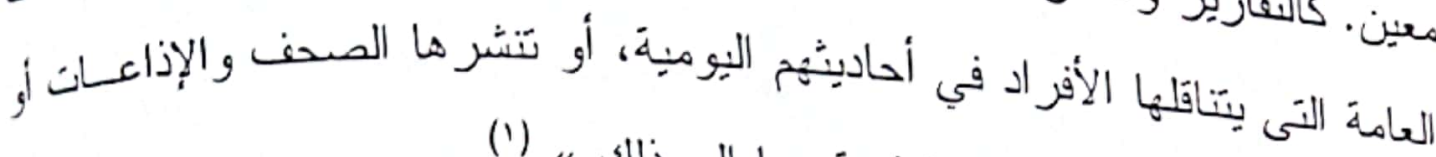

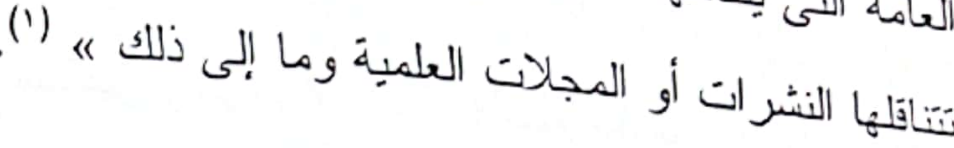
ولغة الصدافة هى اللغنة التى بِنخدمها الكتاب و الصدفيون فـي السصف

$$
\text { و المجلات الصادرة عن مؤسسات صحفية معينة. }
$$

ولا شك أن الصحافة تَفاعل مع غير ها من وسائل الإعلام في أداء وظبنتهبا

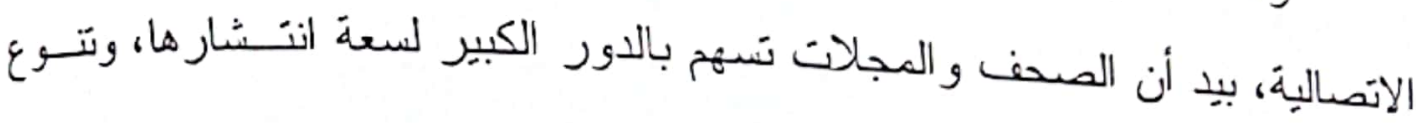
مصادر ها في الحصول على المعلومات. وتأخذ اللغة التى تودي بها الصحف و المجلات وظبنتها أثثكالا وألوانا لغوبة متتو عة؛ لعل أهمها النصوص بوصف النص وحدة كبرى من وحدات اللغة، لها بنبة

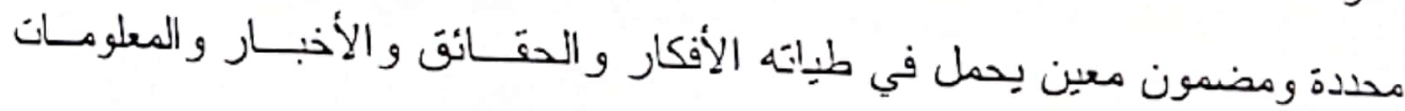
المراد توصبلها إلى المستقبلين أو المتلقين.

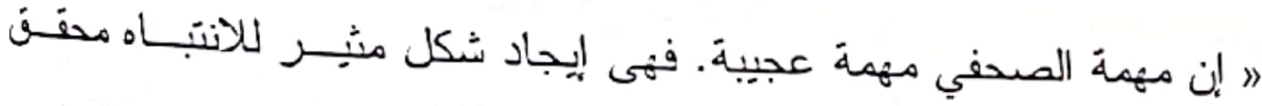

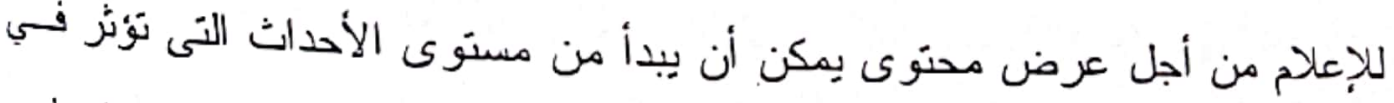
الوضع العالمى لتتنهى آخر الأمر بأقل الموضو عات أهمية و اتصالا بهموم النساس.

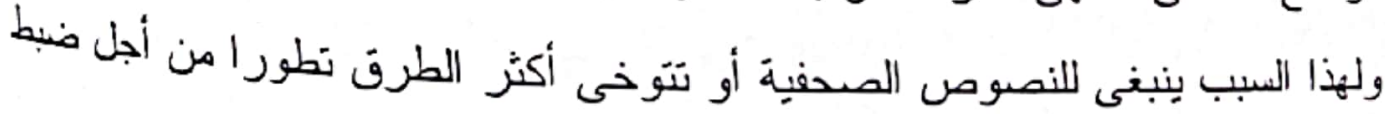

بؤزة الانتباه والإبقاء على الاهتمام و التأثيره (T).

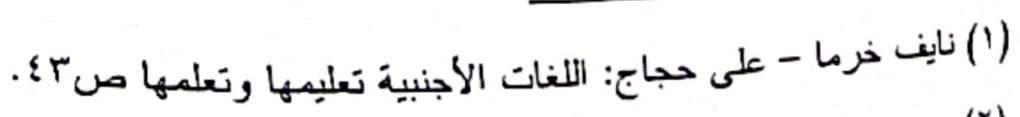

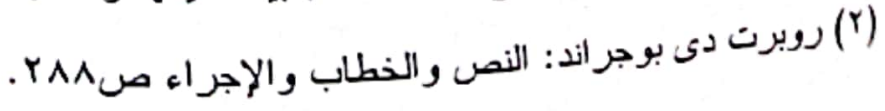


وتتَدد أنواع النص الصحفي بتعدد أشكال التحربر الصحفي التى تتَسم إلى

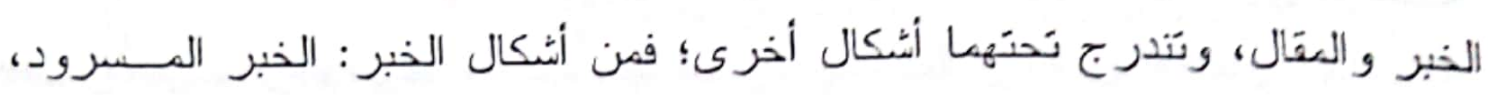
و القصة الخبزية، و التحقيق الصحفي، و الحديث الصحفي، و التقرير .

كLا أن الخبز وفقا لموضو عه ينقسم إلى أخبار سياسية و اقتصادية و اجنماعبة و عسكرية ورياضبة و أدبية وفنية و علمبة.

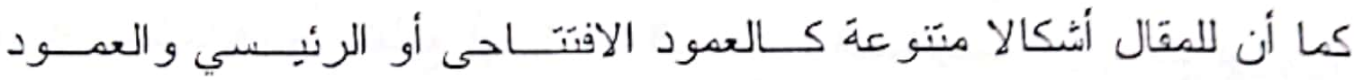

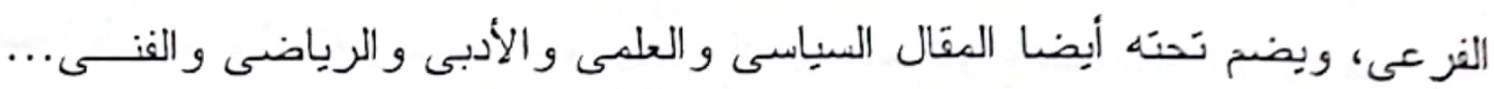

ومن ثُ فإنه بمكن أن نستتنج أن نصر ، الخبر الصحفى تتدرج تحنــه أنــواع

أخرى من النصوص كنص الخبر السياسي ونص الخبــر العلمـى ونــص الذبــر الاجنماعى ونص الخبر الفنى... إلخ

ويشنل الخبر بأشكاله المتنوعة حبزا كبيزلا من الاهنمام في كتابات الصحف و المجلات، لأن الخبر بما يَضمنه من معلومات يجذب اهنمام قطاع كبير من القزاء، وتَّوزع أشكال الخبر في كافة أجزاء الصحيفة، ومن ثم فإنه يشنل مساحة كبيرة في هذه الأجزاء.

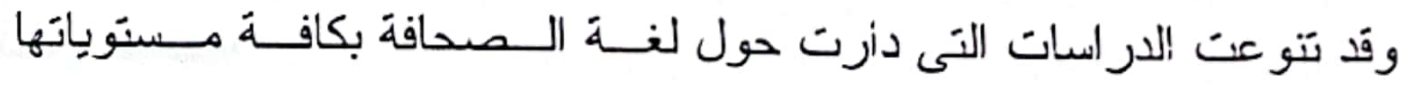
الصرفية و النحوية و المعجمية و الدلالية، ولكن هذه الدراسات لم تتعد مستوى الكلمــة و العبارة و التركيب و الجملة بوصفها الوحدات البنائية للغة التى ظلت مجالا للبحــوث العلمية واهنمام العلماء لفترات زمنية طويلة، ولكنها لم تصل إلى دراسة النـصوص الصحفية، ولعل ذلك يعود إلى أن مجال البحث في النص بصفة عامة مجال جديد بدأ

(1) انظر الدكتور فاروق أبو زيد: فن الخبر الصحفى صع ؛. 


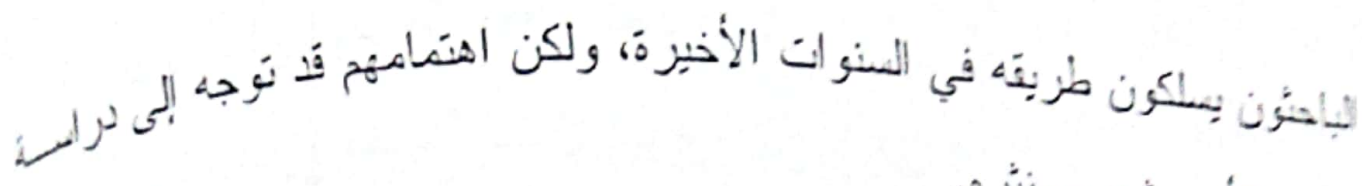

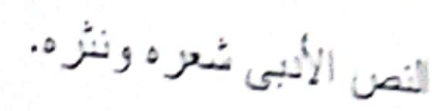

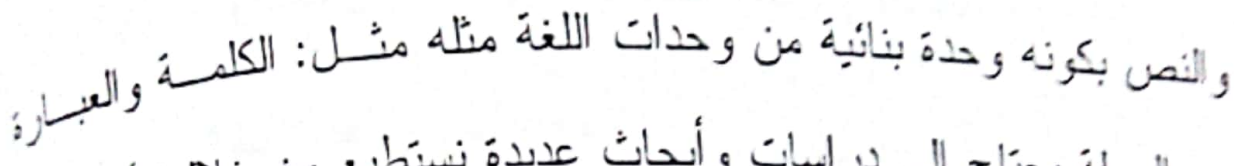

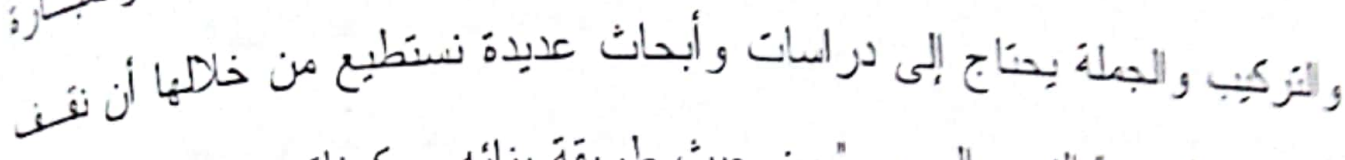

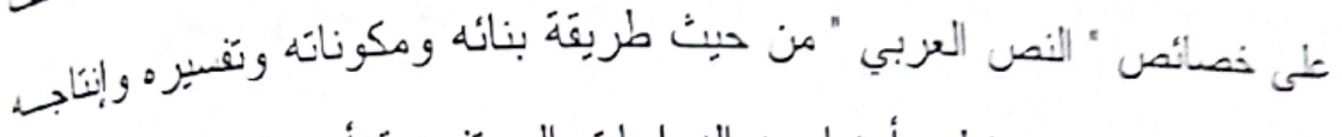

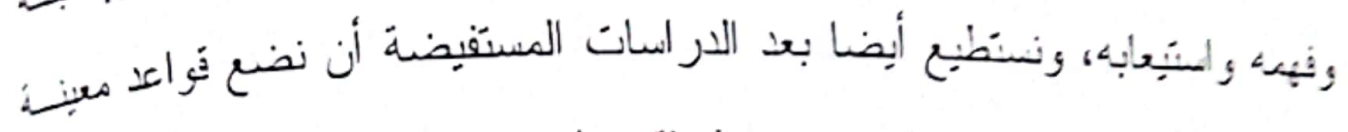

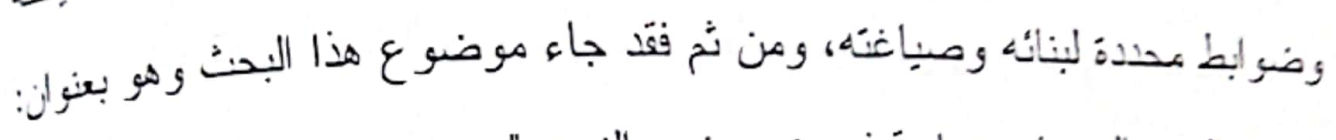
"نص الخبز الصدفي دزاسة في ضوء ندو النص " ويد "نحو النص" أحد فروع " علم لغة النص " الذي بعني بنراسة الجواثب

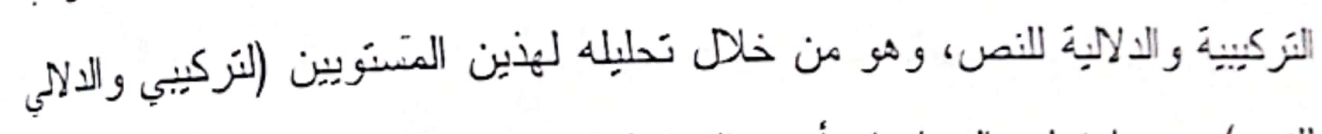

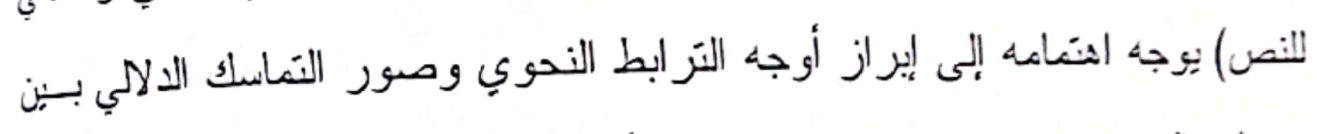

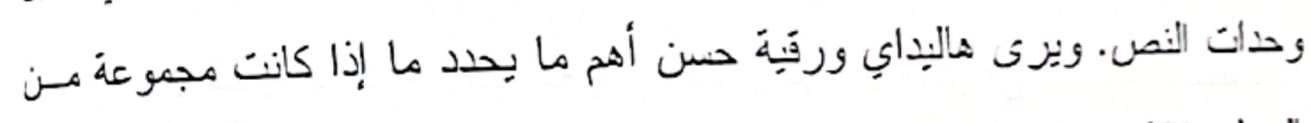

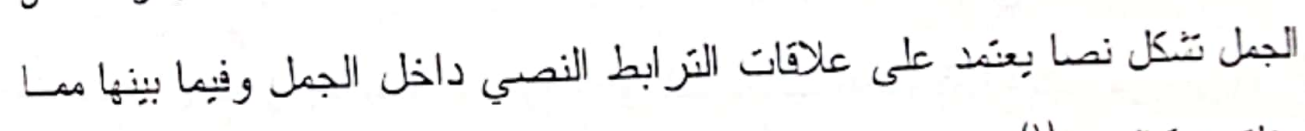

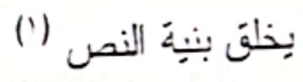

\section{هنهج البحث:}

بعتمد البحت على المنهج الوصفي، لمعرفة خصائص النص الصحفي هن

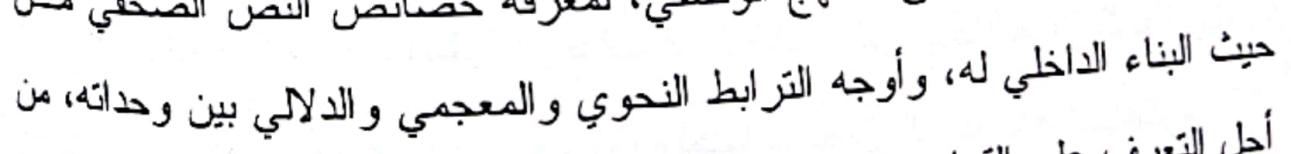

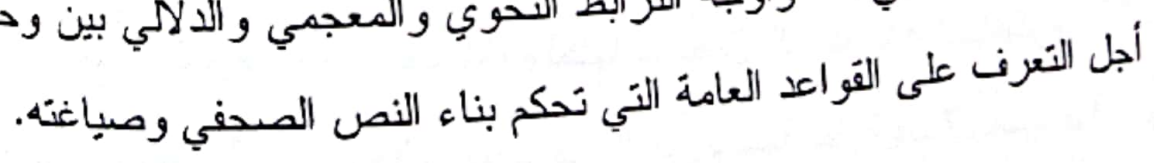

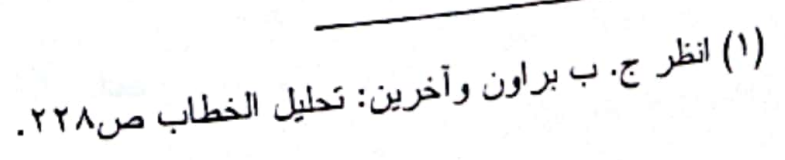


وقد اختار الباحث الصحف القومية وهي الأخبار والأهر ام و الجمهورية لسنة

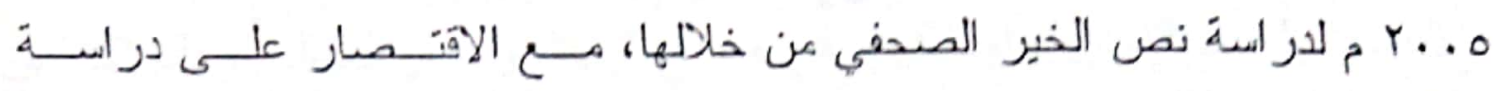
النصوص المكتوبة باللغة الفصدى، واستبعاد النصوص التي كتبت باللغة العامية. ولتحقيق هدف البحث فتّاء جاء تقسيمه في تمهيد وخمسة مباحث وخاتمة

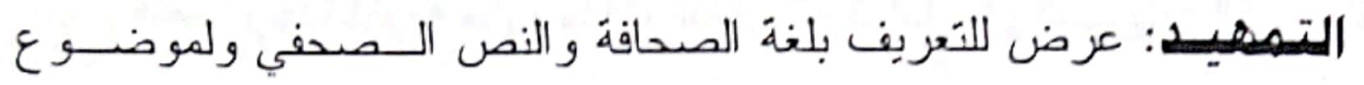

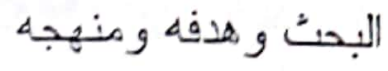
المبحث الأول: بعنو ان جو انب دراسة النص المبحث الثاني: بعنو ان البناء الداخلي لنص الخبر الصحفي المبحث الثُاليث: الترابط النحوي في نص الخبر الصحفي المبحث الرابع: التر ابط المعجمي في نص الخبر الصحفي المبحث الخاهي : التر ابط الدلالي في نص الخبر الصحفي الخاتمهة: وفيها نتائج البحث. 


\section{المبتث الثول}

\section{جوانب درانسة النص}

$$
\text { 1- التص كوحدة لنوبة }
$$

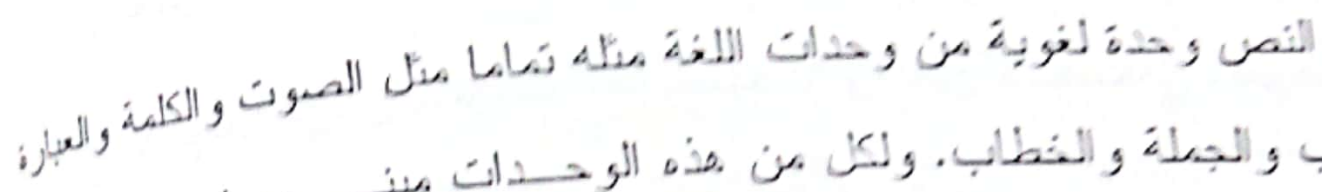

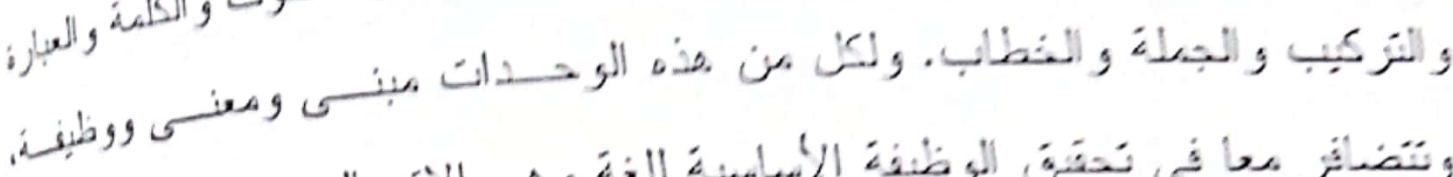

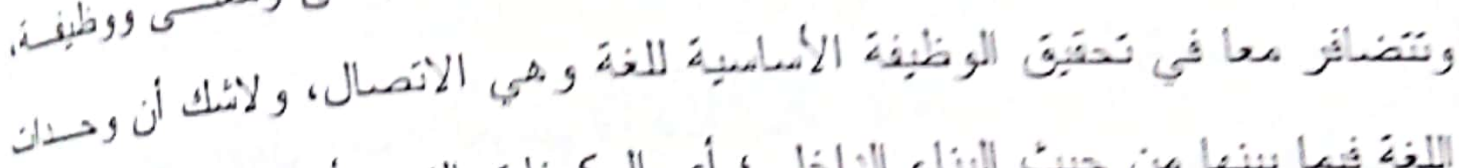

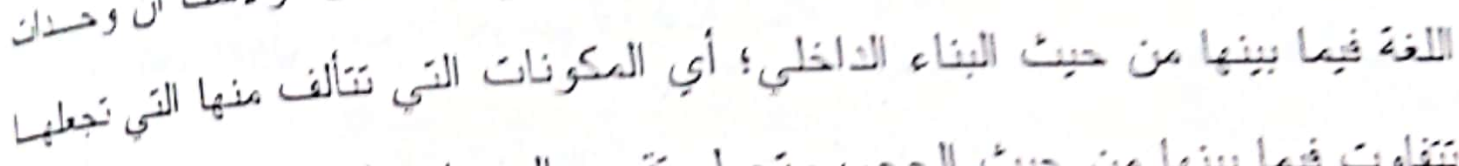

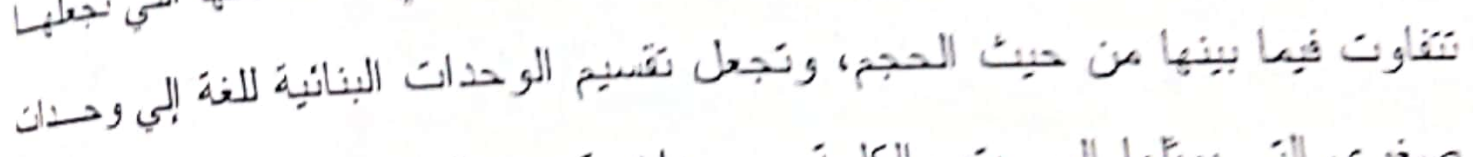

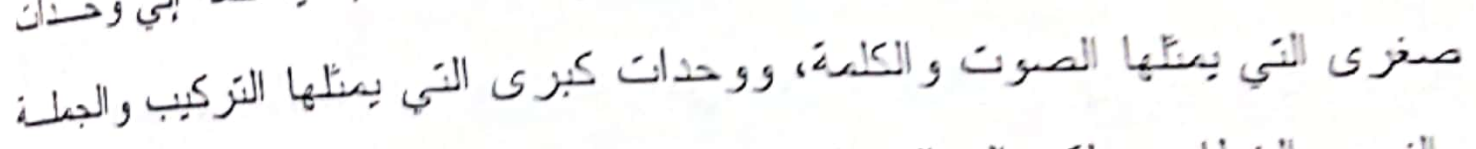

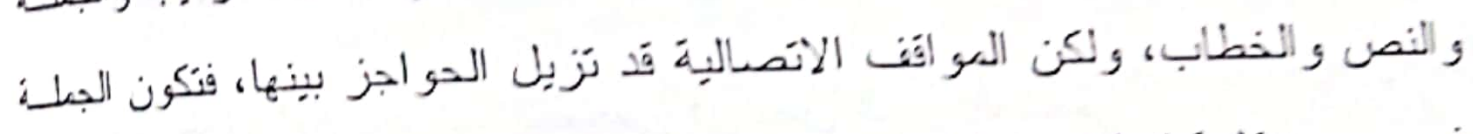

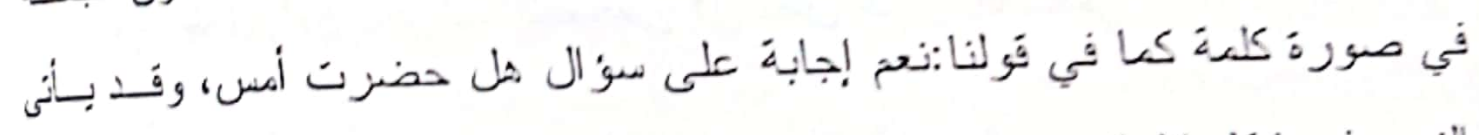

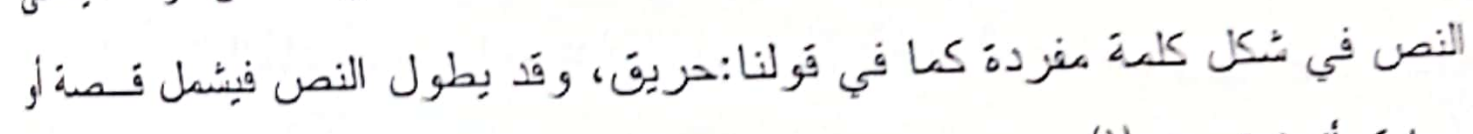

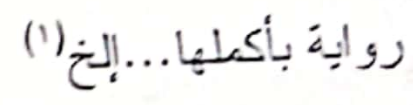

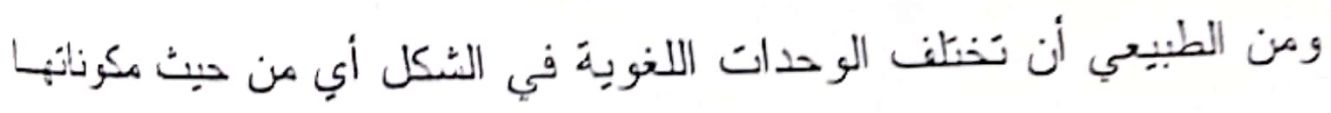
وبنائها الداخلي، فلكل منها أنثاله و أنماطه التي تُشكل هياكلها.

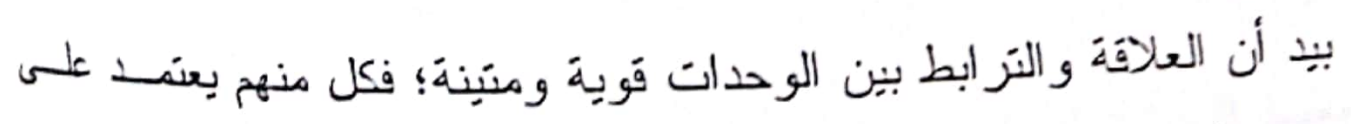

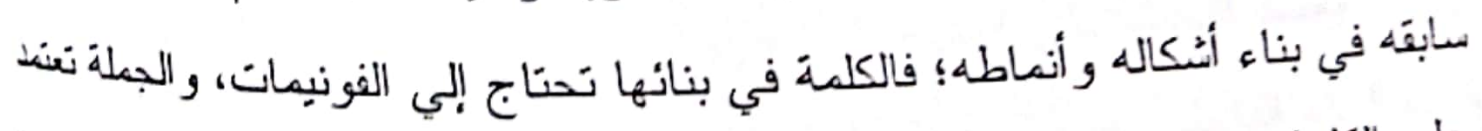

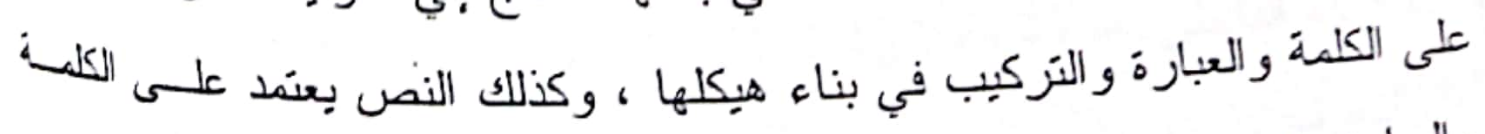

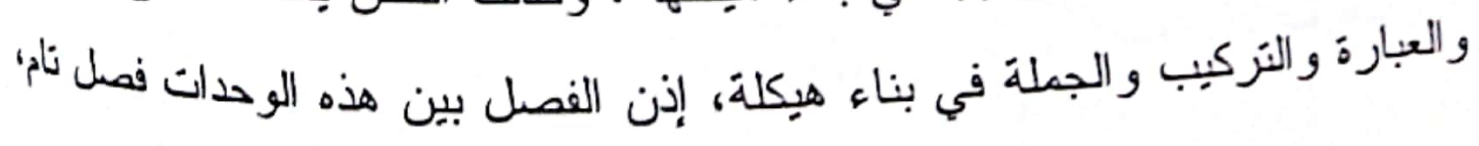

(') انظر روبرت دي بوجر اند: النص والخطاب والاجر اء ص VY. 


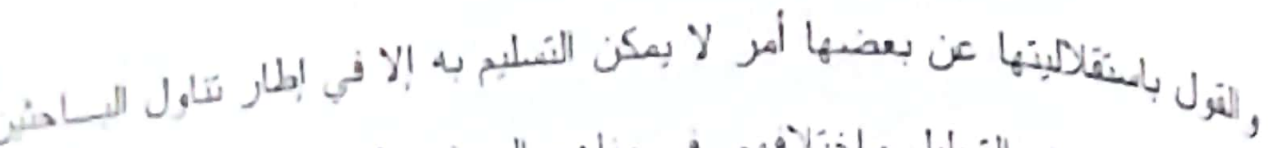

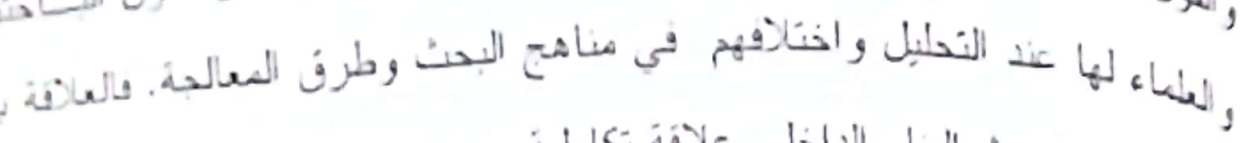

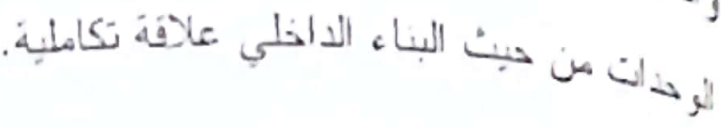

$$
\begin{aligned}
& \text { TEXT بريف النص }
\end{aligned}
$$

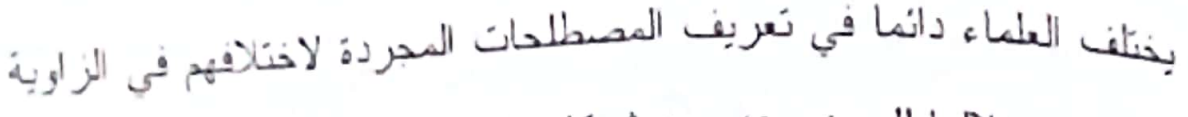

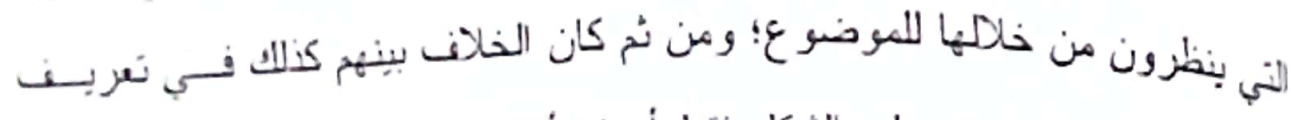

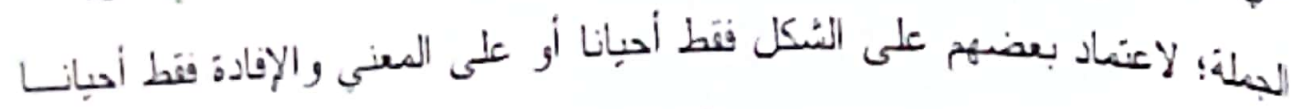

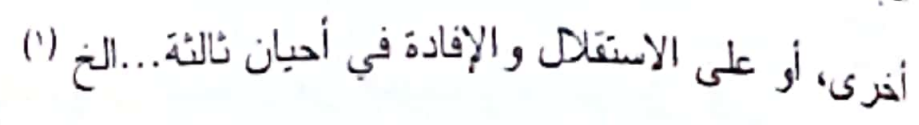

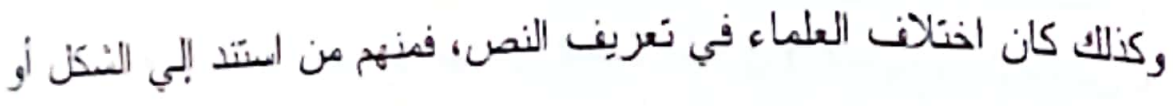

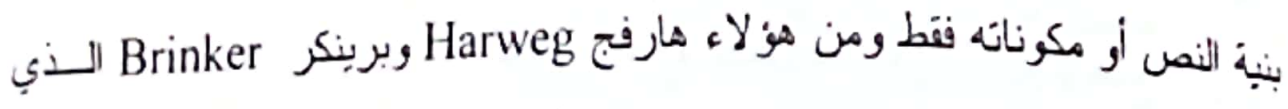

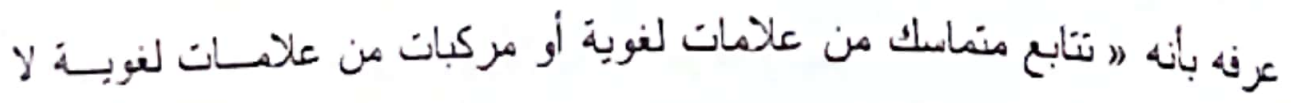

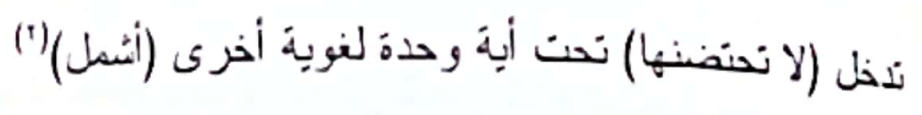

ومن العلماء من اعنمد على المعني أو المضمون فقط ومنهم برنبكر الذي

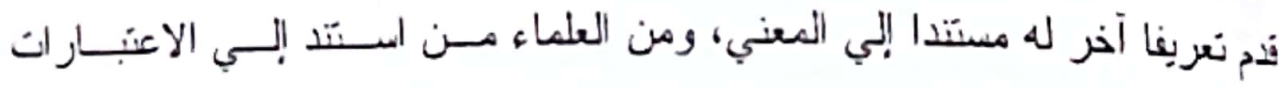

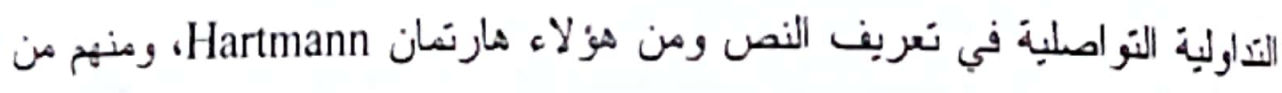

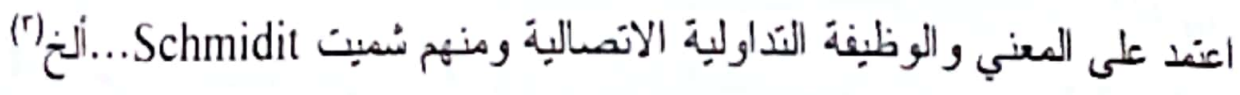
على أبة حال فابن أي نعريف للنص ينبني أن بنضمن ثُلاثة جوانب:

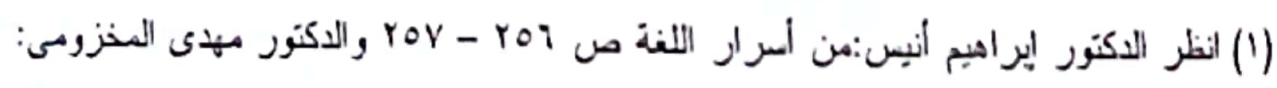

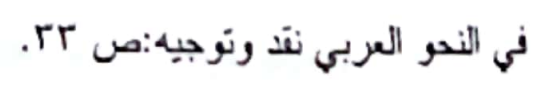

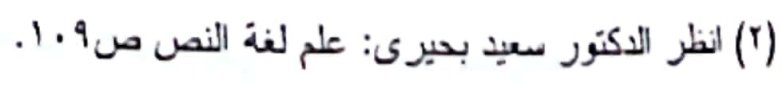

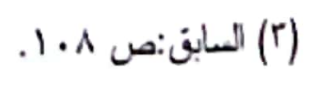




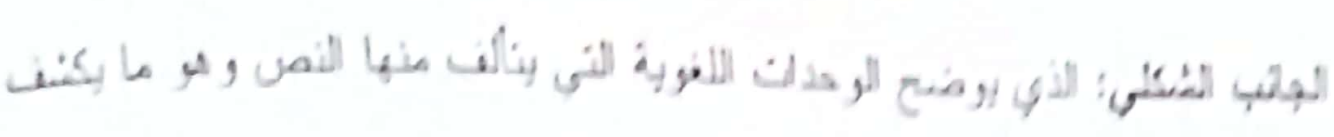

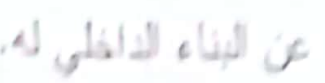

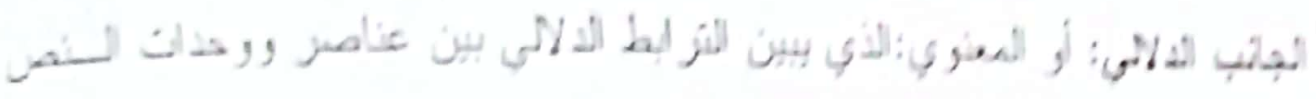

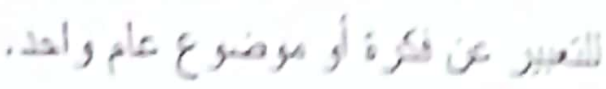

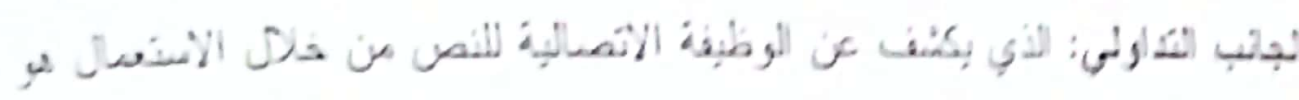

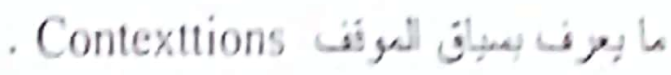

\section{ب- بين الجذة و النص:}

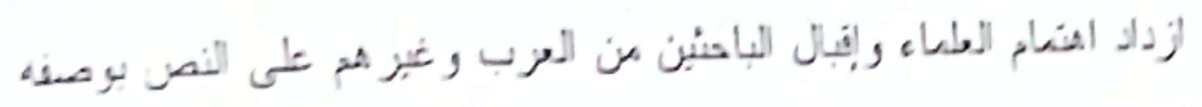

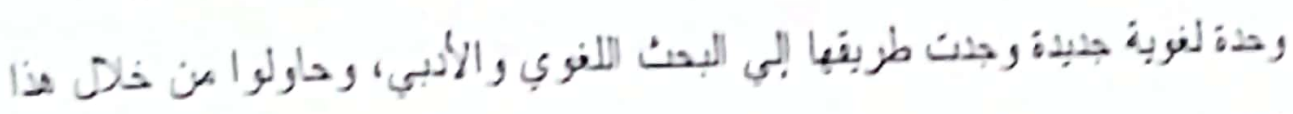

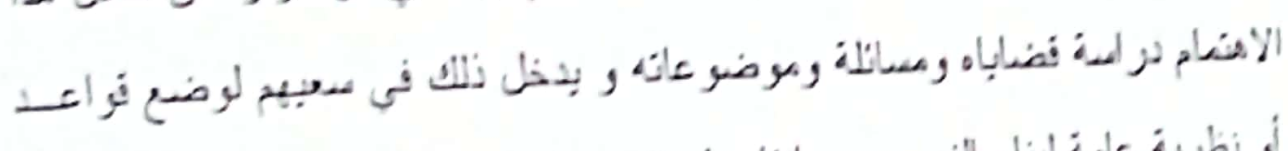

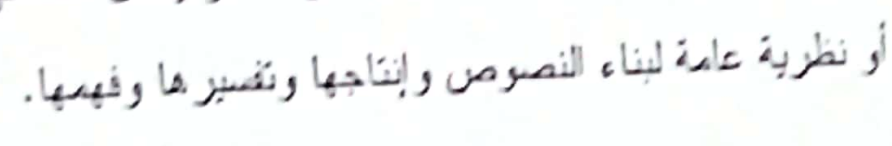

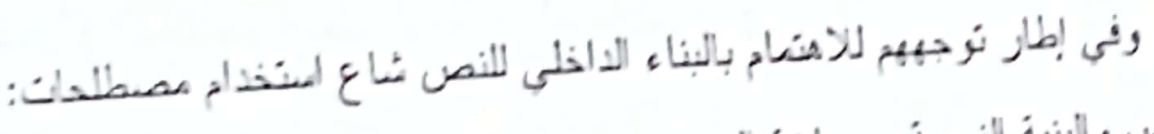

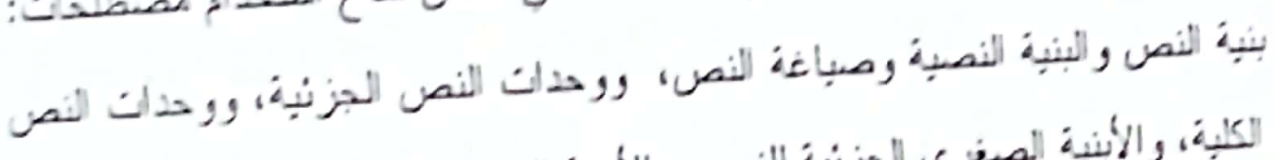

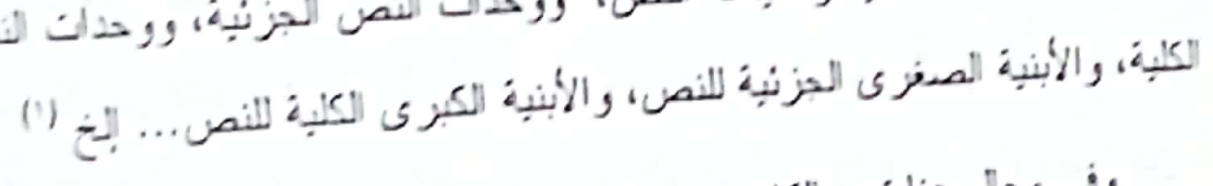

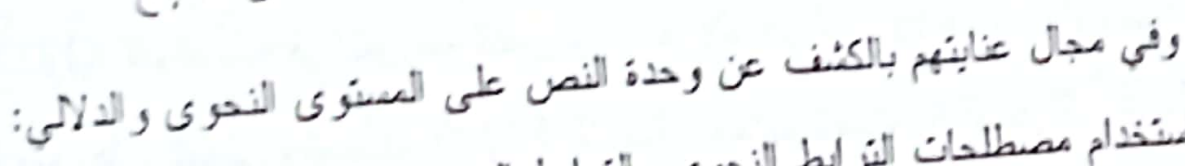

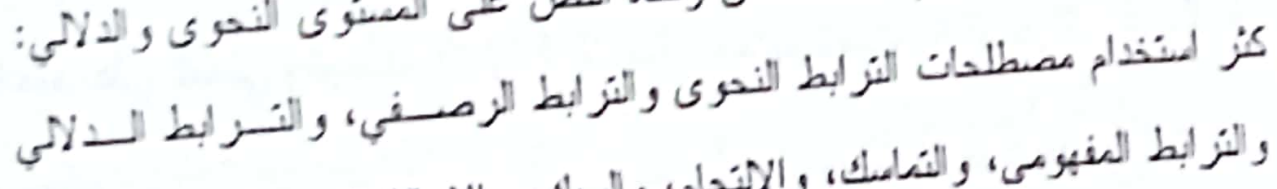

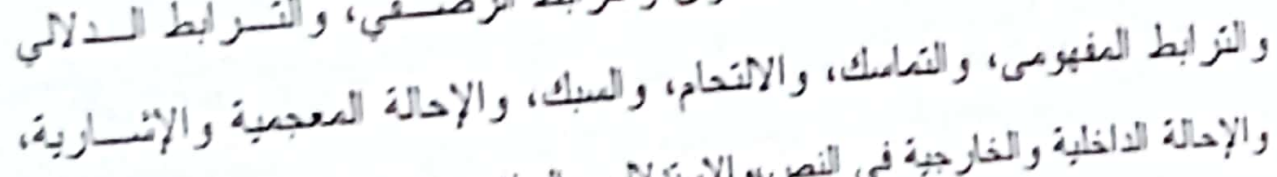

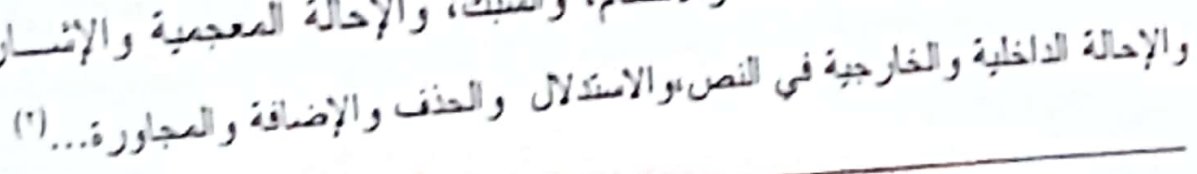

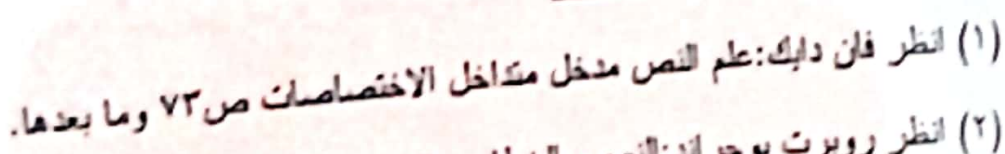

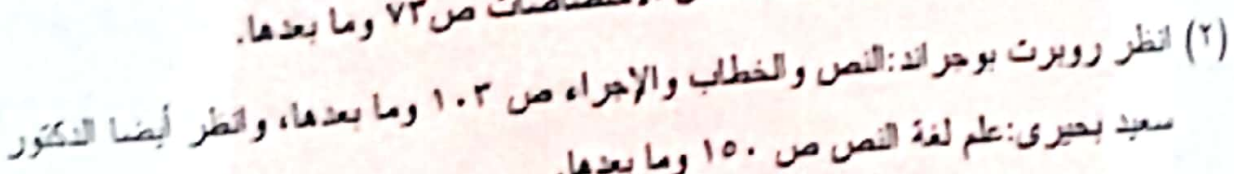

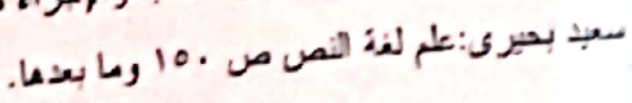




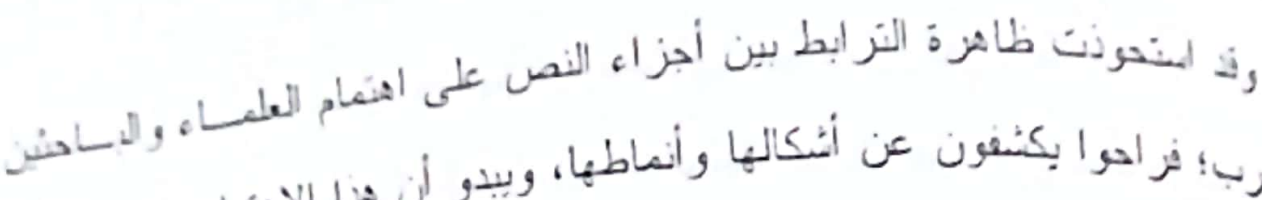

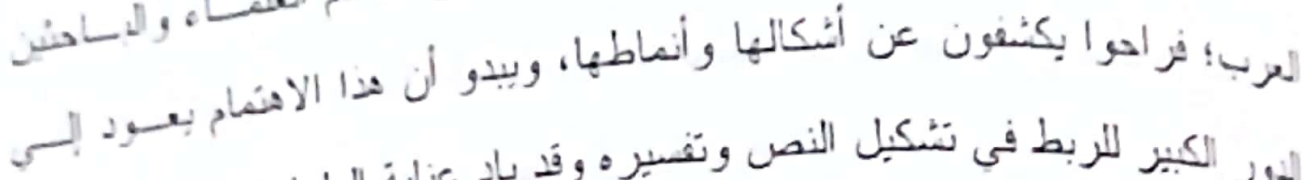

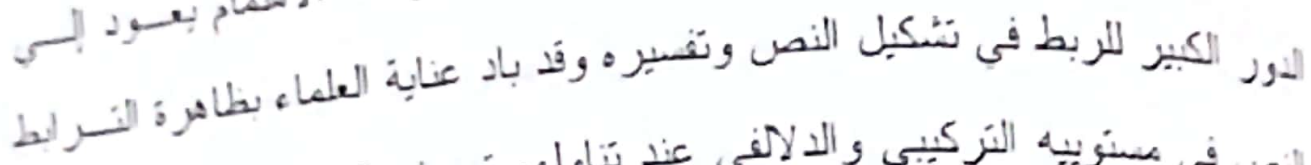

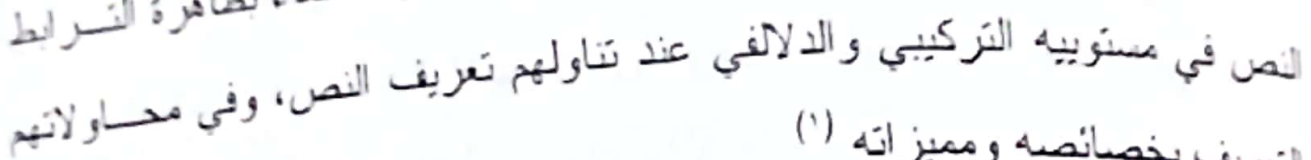

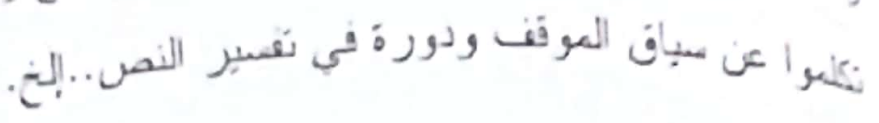
فهيا اختلف العلماء حول نَّديم تعريف جامع مانع للسنص إلا أن هنـاك قاسما مشنركا بين هذه التعريفات وهو أن النص يعد وحدة مكونة من عدة عناصسر لفوبة بينها تعاسك أو تر ابط.

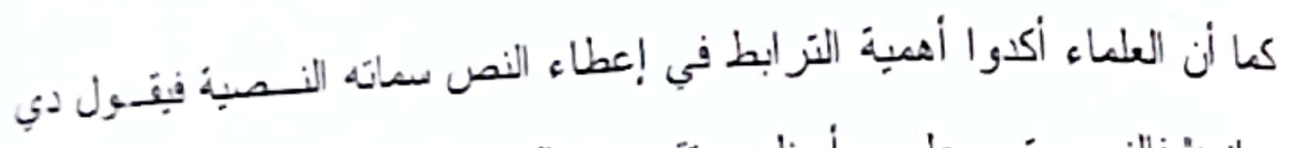

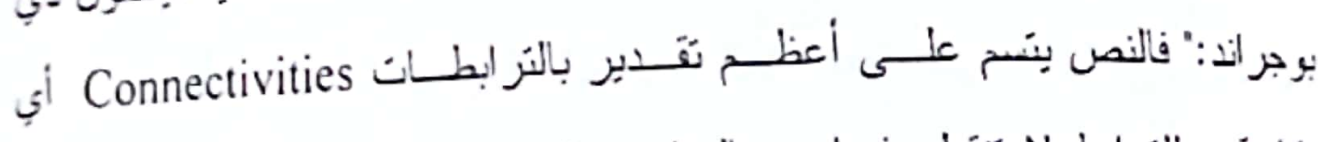
بانتادة... للنز ابط لا تنفطع فيما بين العناصر الو اردة من النظم اللغوبة المساهة...

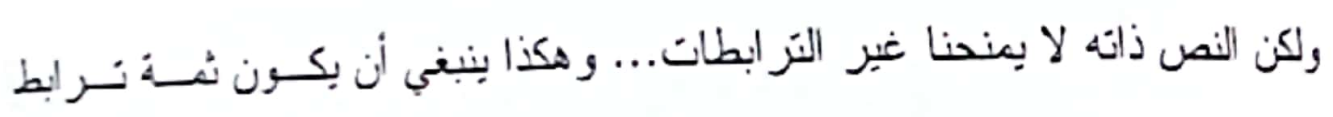

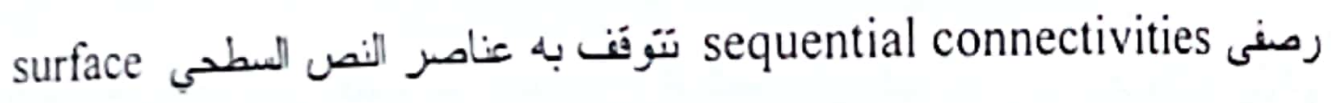

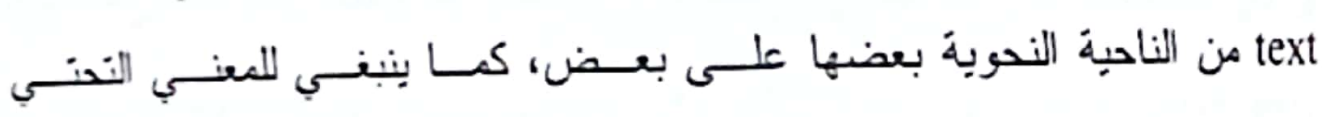




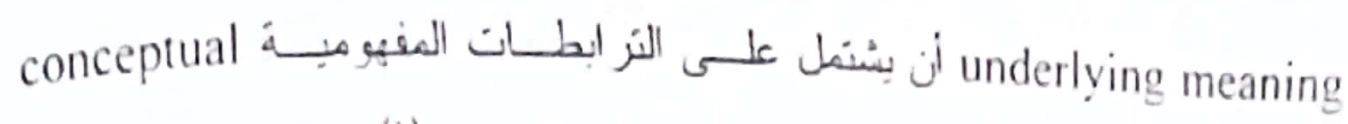

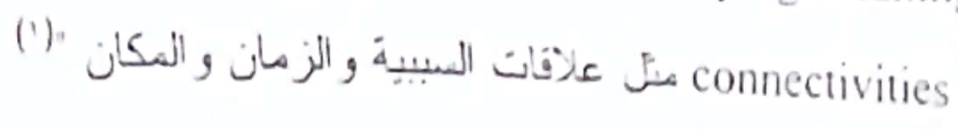

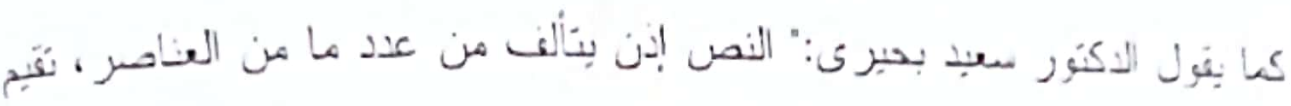

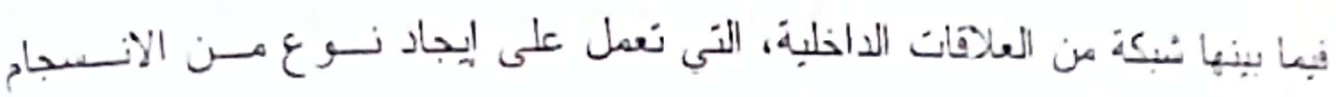

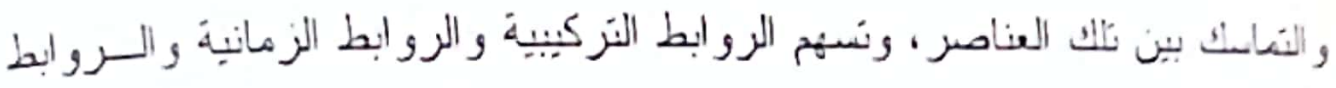

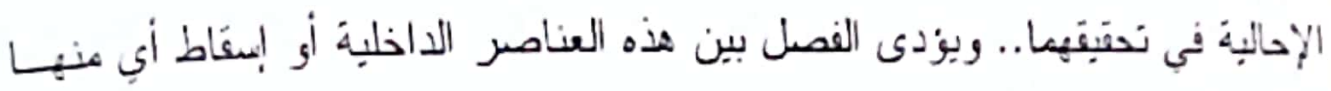

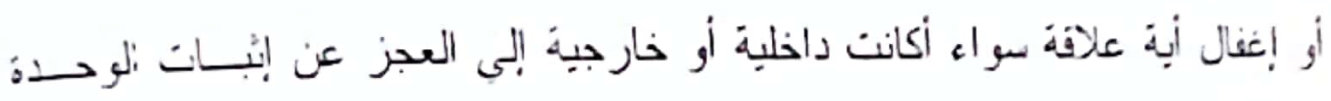

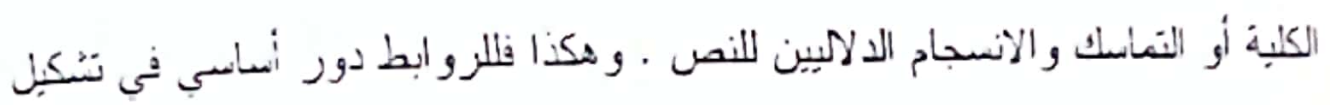
النص سواء كان ذلك ببن جملة أو مغرداته ه|(")

إن مجال البحت في النصوص العربية ماز ال بكزأ بحتَاج إلي جهـود منو اصـلـة

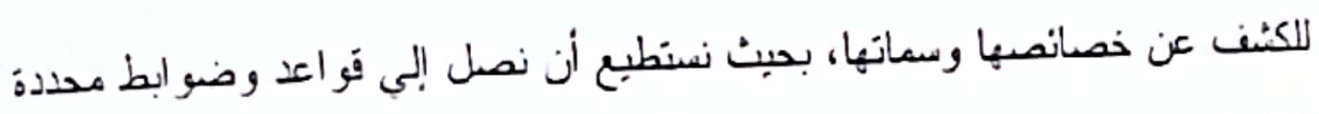

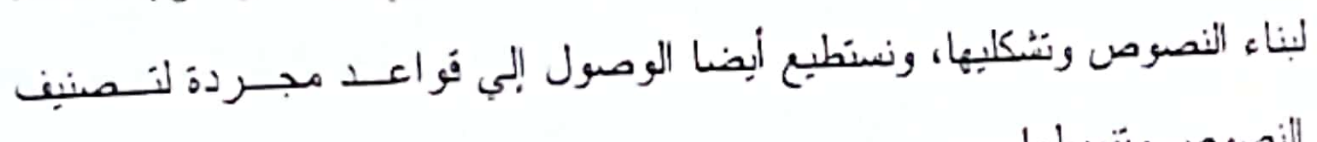
النصوص وتنميطها.

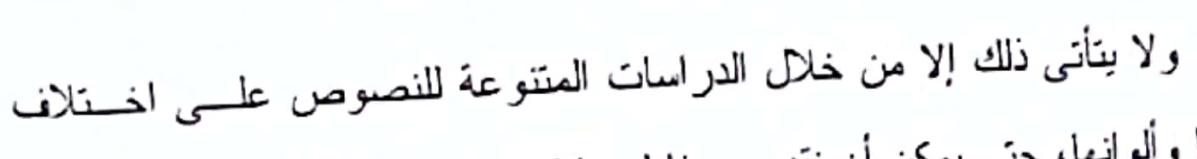

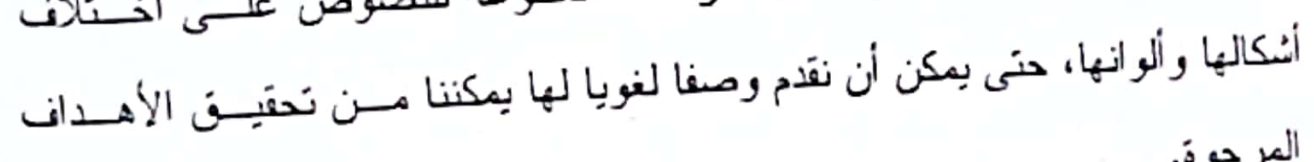

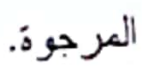

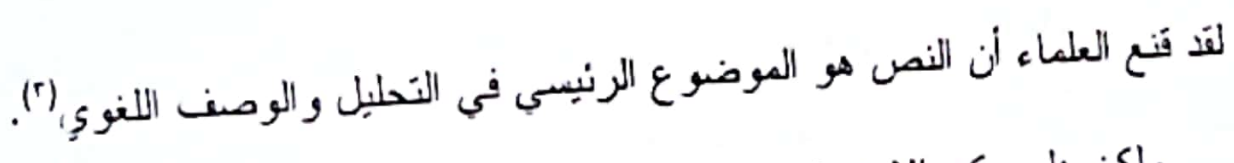

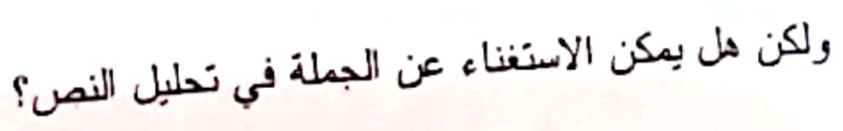
(1) (1) النص والخطاب والاجر اء: ص 99.

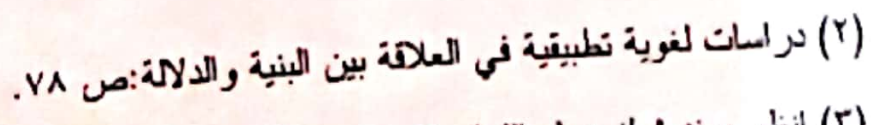

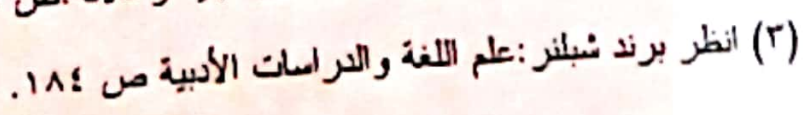




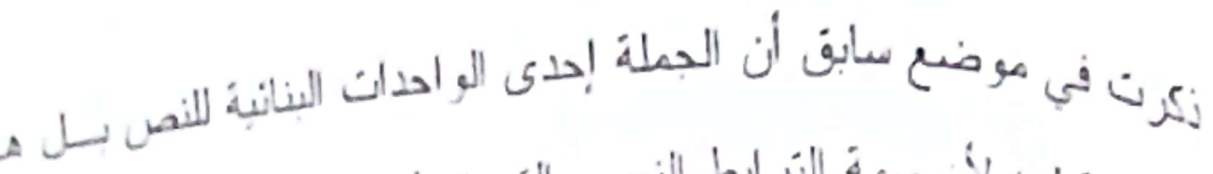

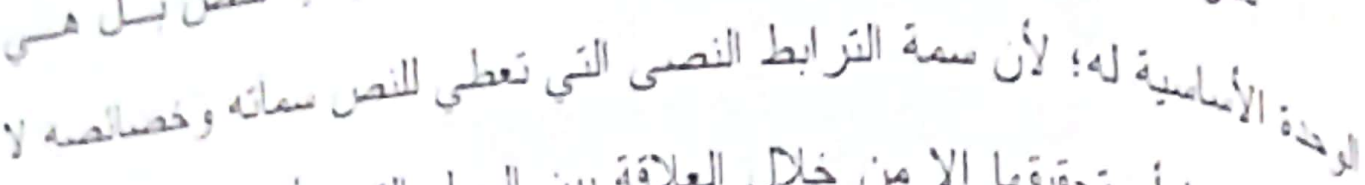

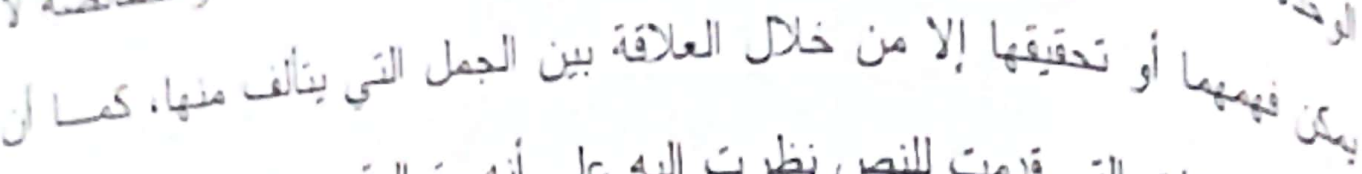

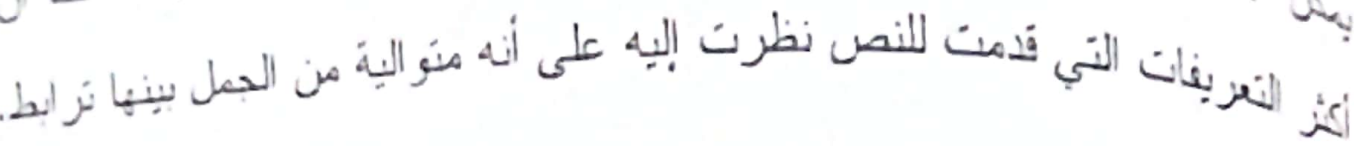

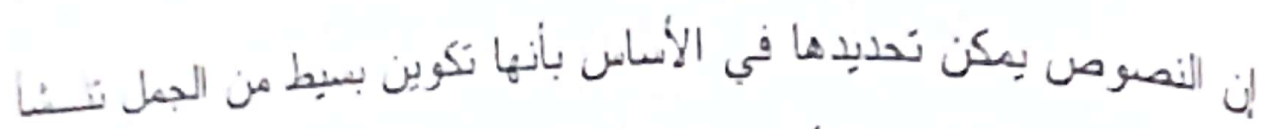

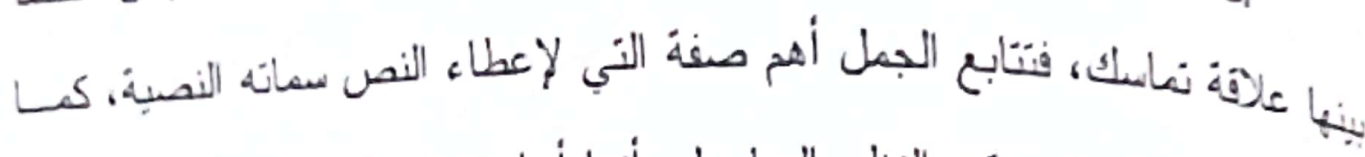
أن نزابط هذه البمل بمكن النظر البها على أنها أساس وشرط لإبضاح علبات ابتّاج und

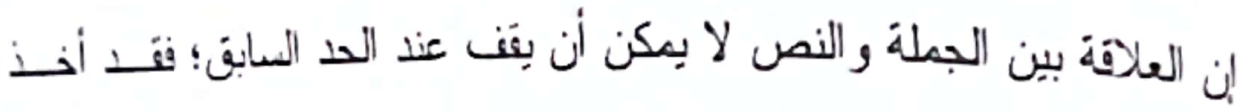

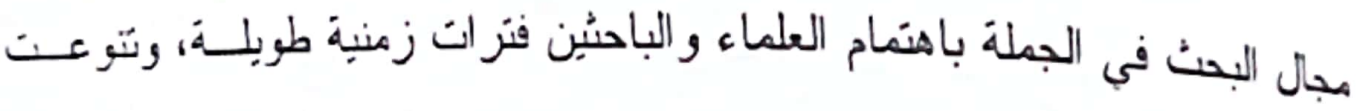
طر انقه و اتسعت أطر افه ونو احبه، كما تعددت مناهج البحث فيها وتتو عت النظربات هولها.

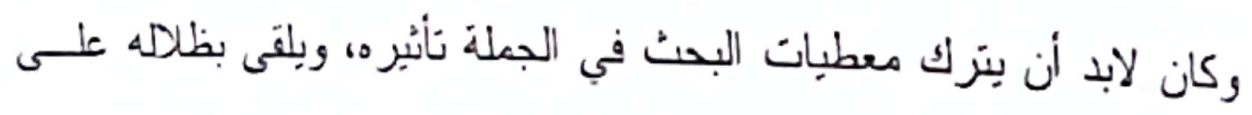

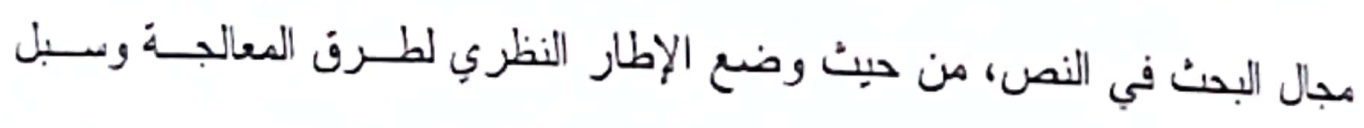
التتاول الخاصة بالنص. لا ينبغي أن نشك في وجود فرق في البناء الداخلي ومناهج البحث بين الجملة

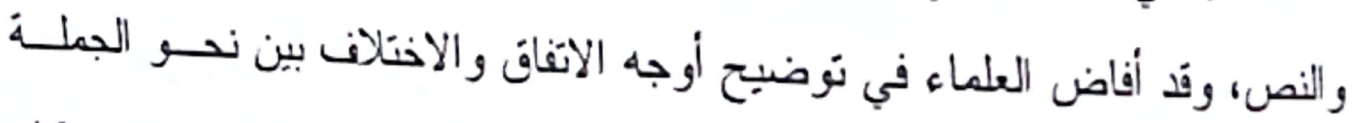

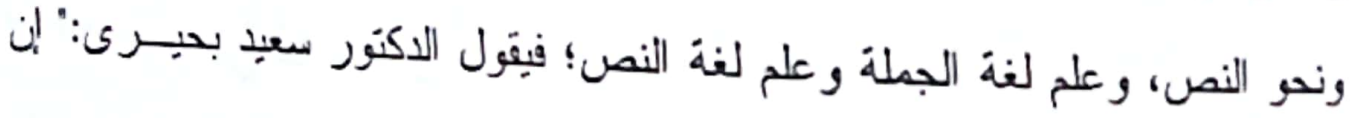

(1) النظر فولنجانيح هاينه مان وأخرين:مدذل إلى علم اللغة النص ص 19-T. 


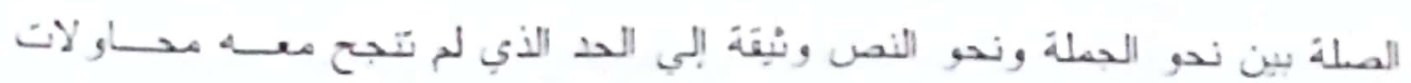

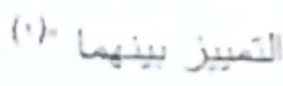

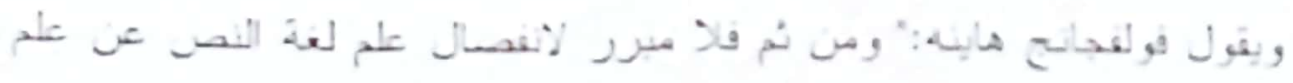

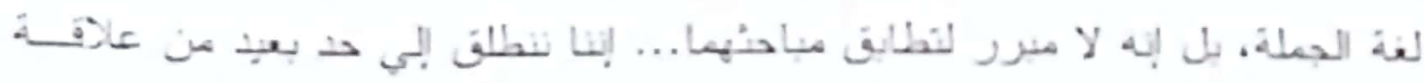
تكامبية بين على النص و الجملة، حبث بنظز إلى بحوث عم لعة الجملة على أنهب

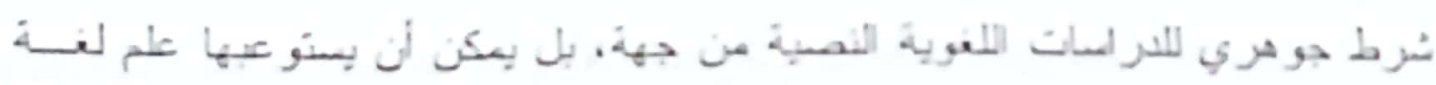
النص الفماسل سن جهة أخرى (1)

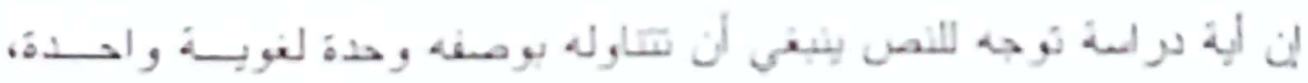

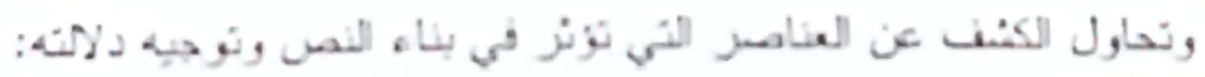

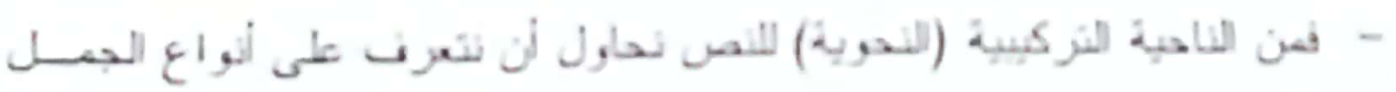

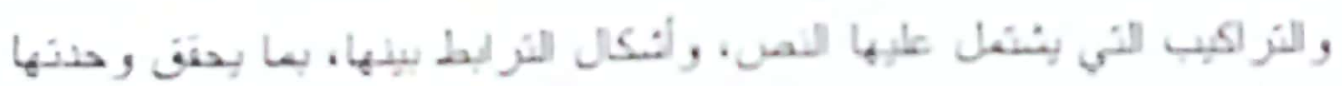

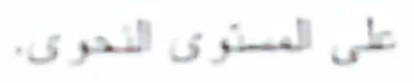

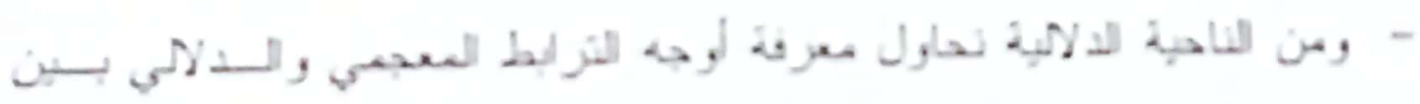

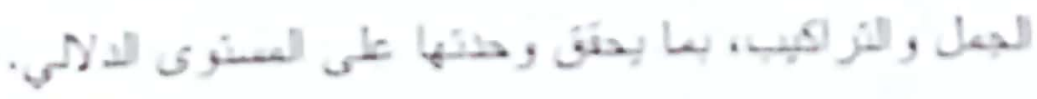

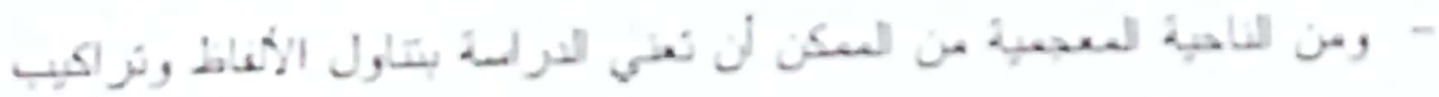

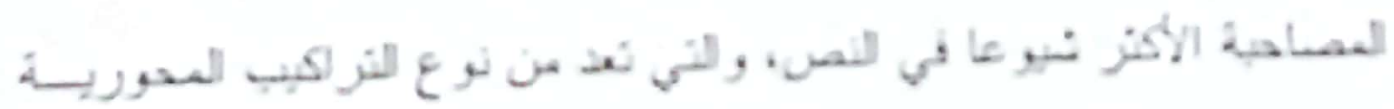

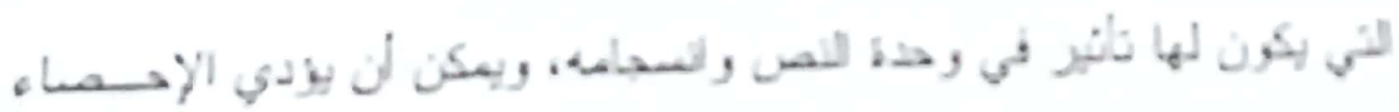
.

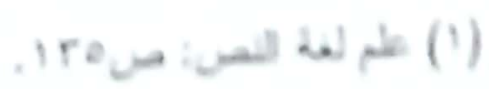

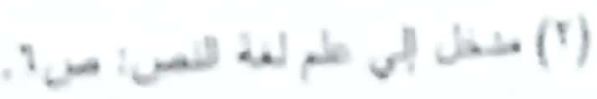




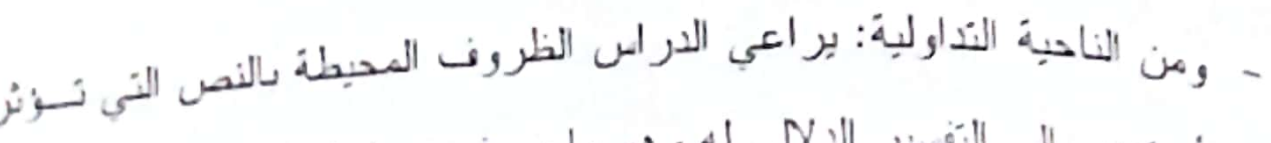

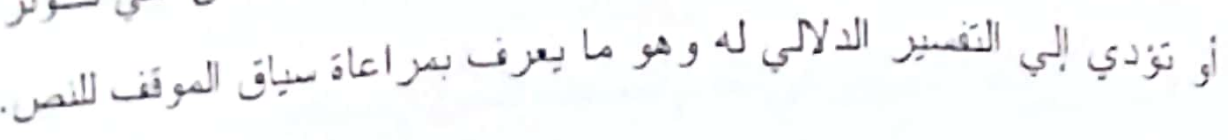
؛ - أنى اع النصوص:

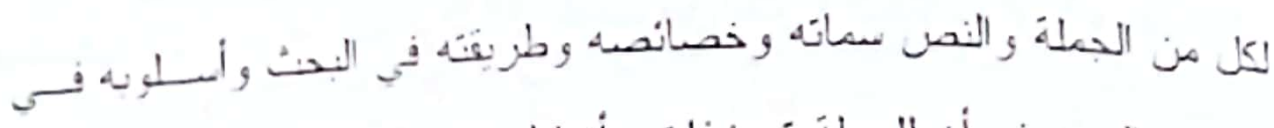

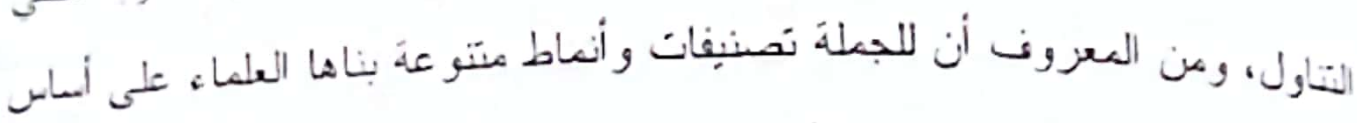

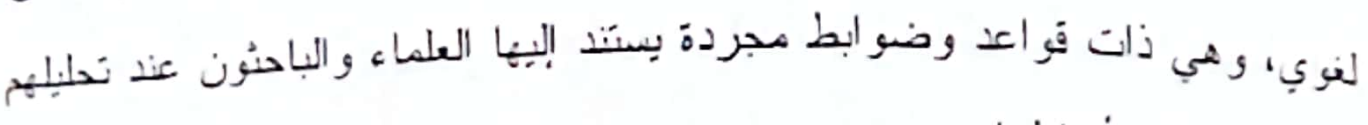

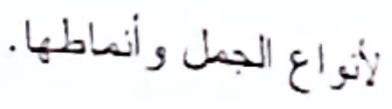

فهل يوجد نصنيفات للنصوص و أنو اع و أنماط؟ و إذا كان كذلك فما هي المعايير

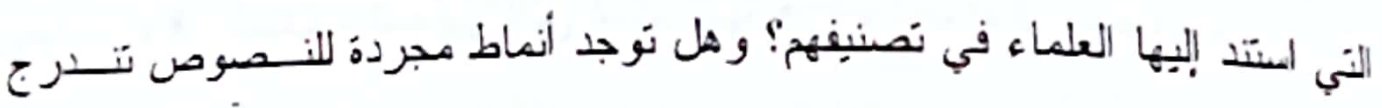
تحنها أشكال مختلة:

تختلف طريقة تصنيف النصوص عن طريقَة تصنيف الجمل، وفُ خـضعت

غالبية التصنيفات العقدة للنصوص لاعتبار ات تذاولية حبث تركز في نظرتها للنص على أنه حدث في سياق اتصالي معين، وقد تتعدد المعايير الخاصــة بتصنيف النصوص، ولكن ينبغى أن نفهم أن هناك فرفـا بــين أنـــواع النـصوص و أنعاطها، فانواع النص أو فناته تعد "قدرة، رصبدا محدذا من المعارن برجع إليـهـ أعضاء جماعة بُُرية في نشاطهم اللنوي. وتحدد حاجات الاتصال التي تتـنسأ فـي جماعة بشرية بنية ومدى هذا و القدرة الخاصة بأنو اع النص أو فئاته... أمــا نــط النص فعل العكس مما سبق يفهم على أنه مقولة مرتبطة بالنظريسـة فــي التــصنيف العلي للنصوص الذي يرتبط بصيغة ظاهرة في النصوص توصف وتعدد في إطار تتميط النص أو المحادئة - فلدي المتكلمين في الجماعة البُُرية تبعا لــللك معرفــة 


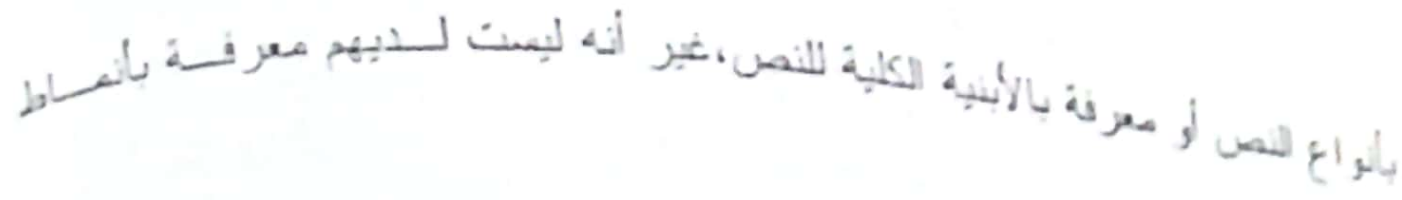

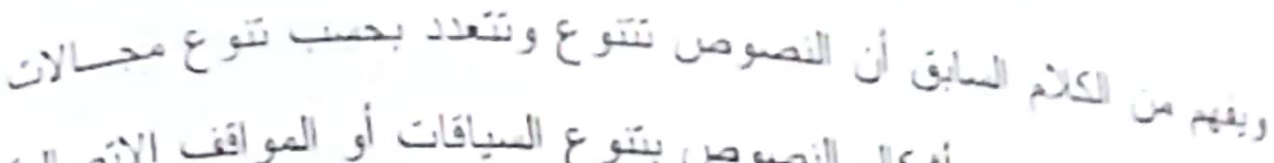

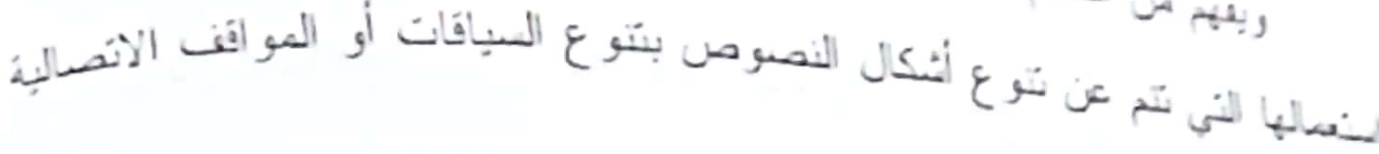

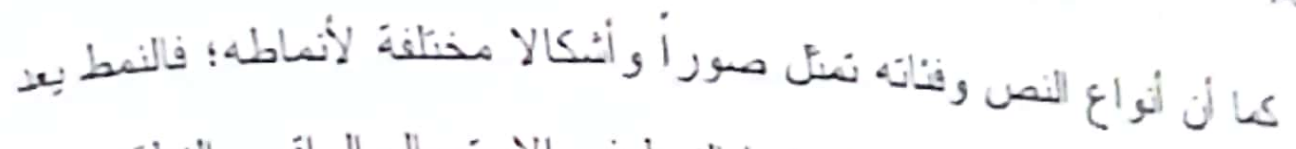

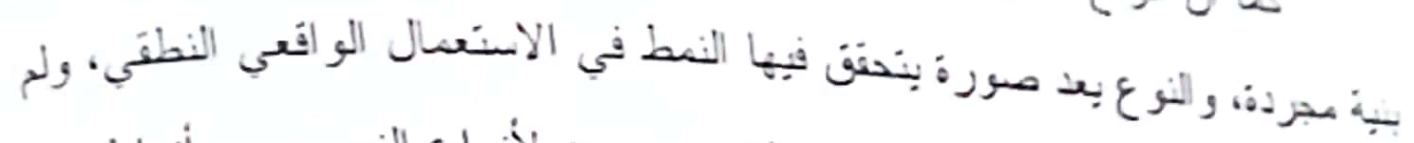
بنظع الفلاء خنى الآن وضع نصور و اضح وموحد لأنو اع النصوص و وانماطبهـا.

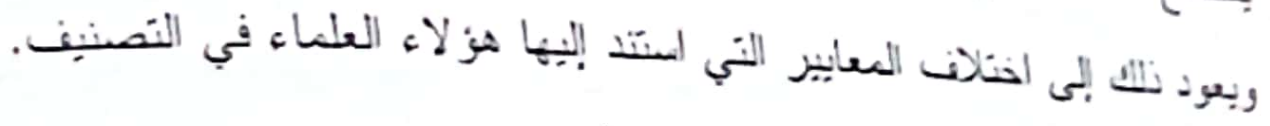

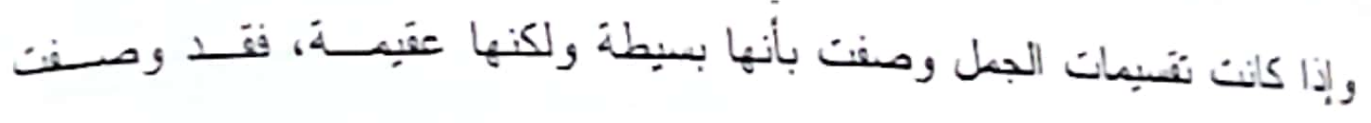

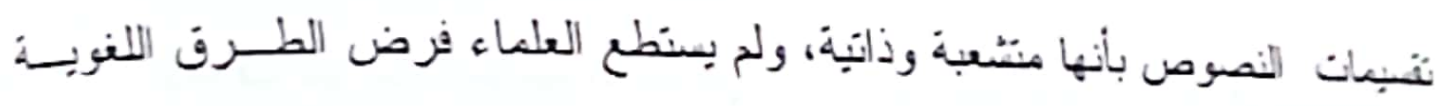

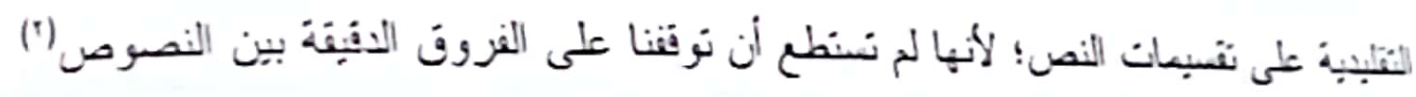

كا أن صعوبة الوصول إلي تصنيف محددة للنصوص يعود إلـي أن هـــه

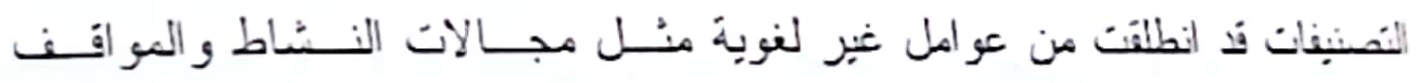

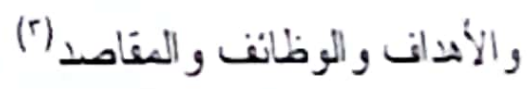

ومن المعايير الني استتد إلبها العلماء في تصنيف النصوص:

$$
\begin{aligned}
& \text { ب- الاعنبار ات الوظيفة } \\
& \text { أ- الاعتبارات النَاولية }
\end{aligned}
$$

ج-مضمون النص أو البنبة الكلية للنص د- اعنبار ات نشكلية.

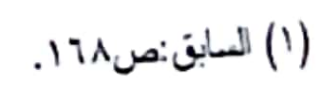

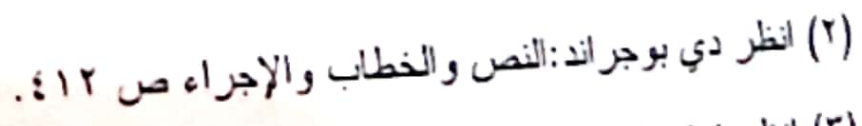

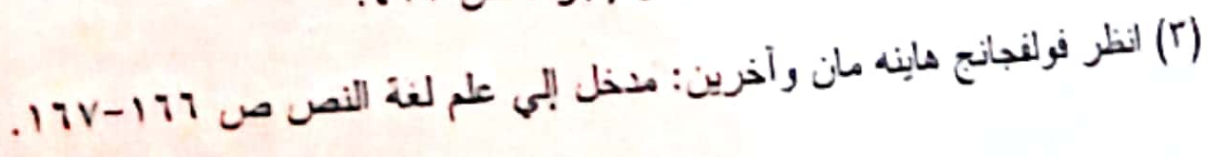





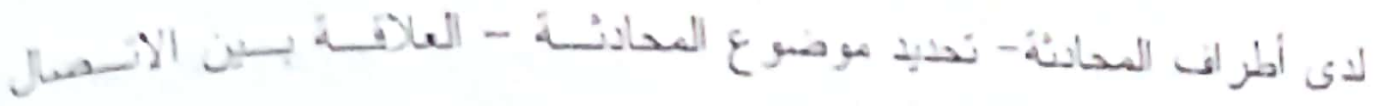

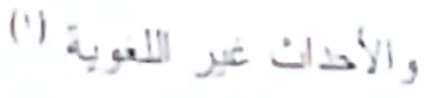

$$
\begin{aligned}
& \text { - وقد تسم بوحر الـ النحسوص إلى أنواع هي: }
\end{aligned}
$$

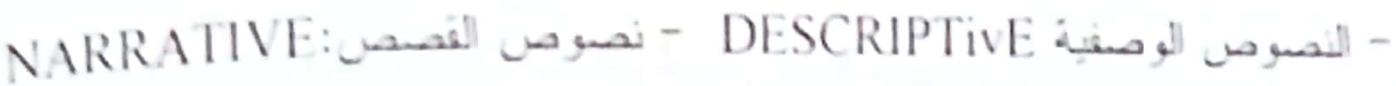

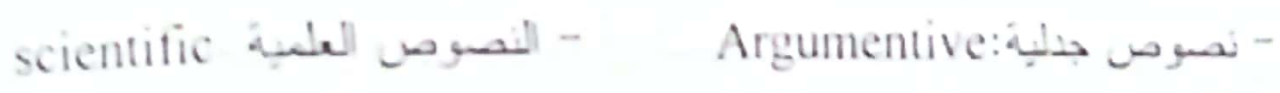

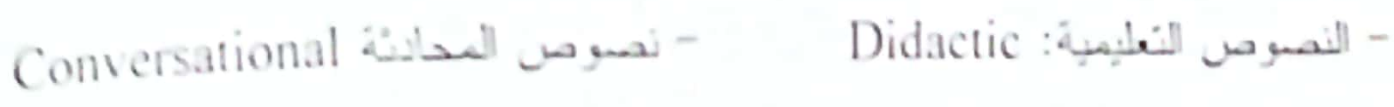

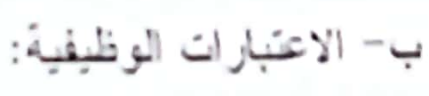

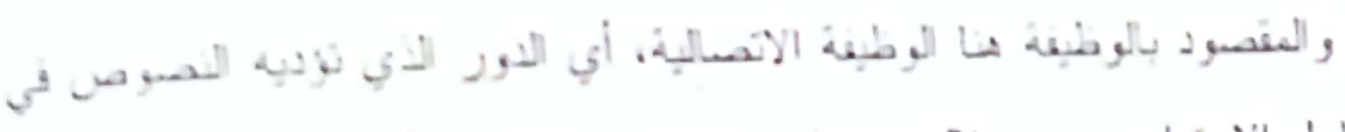

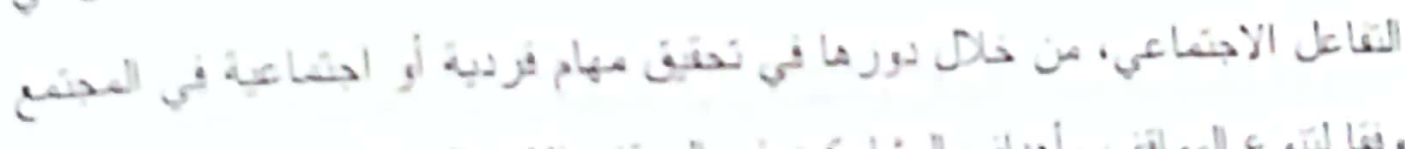

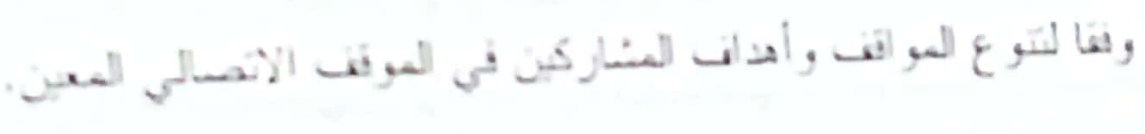

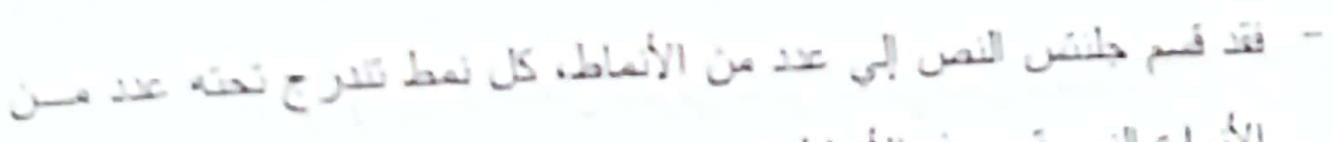

$$
\begin{aligned}
& \text { الأو اع النسبة، و هذه الألعاط هي: }
\end{aligned}
$$

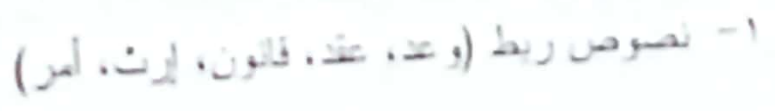

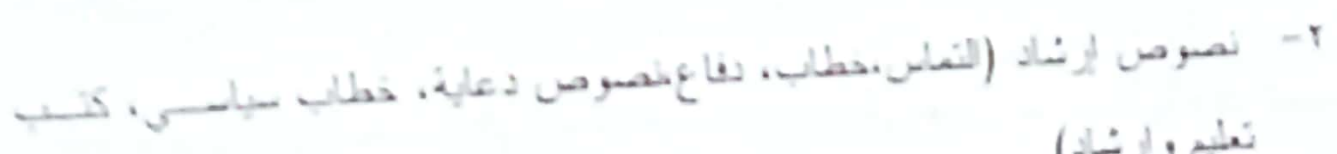

$$
\text { نئم }
$$

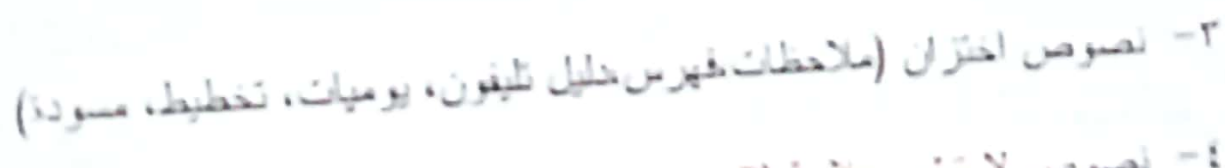

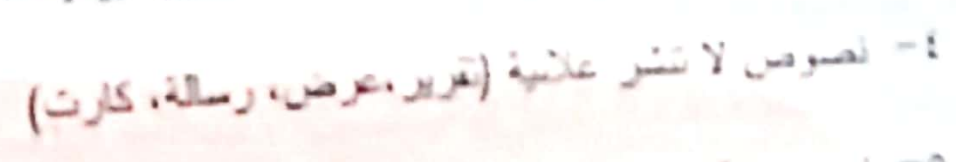

"0

$$
1110 \text { o (1) }
$$

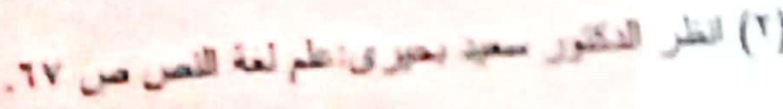




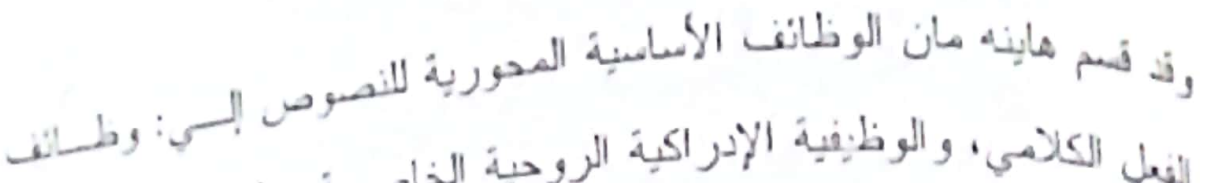

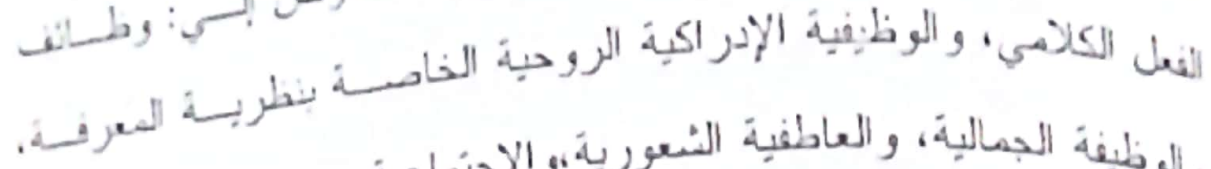

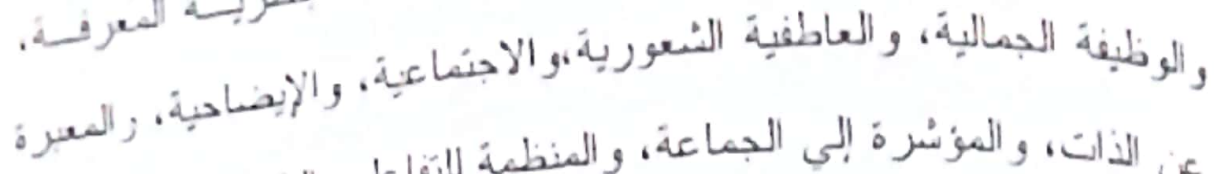

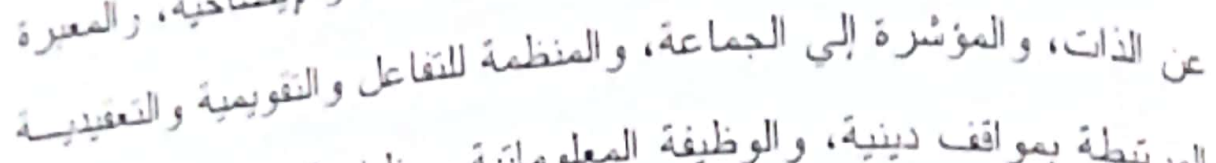

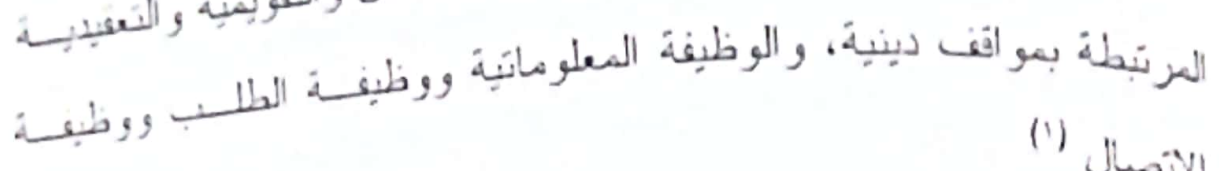

(1) the

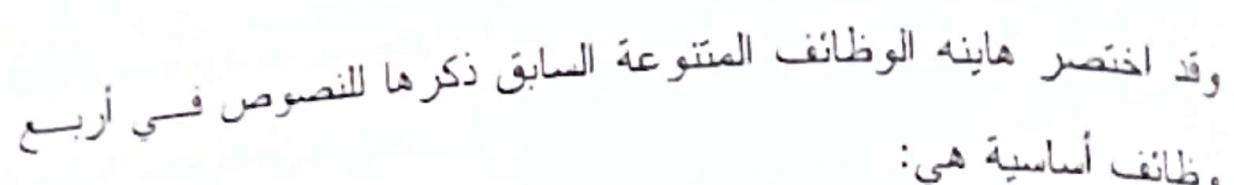
وظانف أساسية هي: وفئ - مظنية التعبير عن النفس - وظبية الاتصال
- وطنية النو جيه
- مظنيفة الإبلاغ

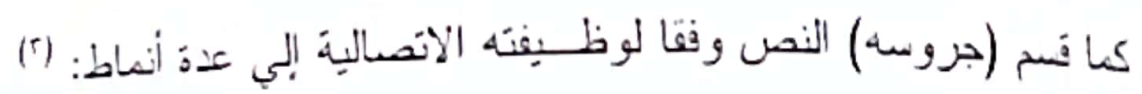
وظيفة النص

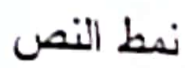

وظنيفة مبرِرية

1- نصوص معيارية

وظيفة انصلية

r- نصوص اتصال

وظنيفة مؤشرة إلب جماءة

r- نصوص مؤشرة إلي جماعة

وظبفة شعربة

؛- نصوص شعرية

وظيفة دالة على خصوصبة غالية

$$
\text { - م- نصوص ذات خصوصية }
$$

(') منل إلي علم لغة النص:ص IVr.

$$
\begin{aligned}
& \text { ("ا) السابن: ص1V0. }
\end{aligned}
$$

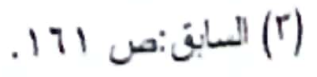


وظيفة طلب

T- نصوص دانة على طلب غالبا

(وظيفتان منساويتان في الغلبة)

V- فئة انتقالية

وظفيفة نَل معلومة

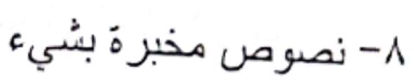

موضو عي غالبا

ج- مضون النص أو البنية الكلية للنص:

و المقصود هنا بمضمون النص الاعتماد على خصائص بلاغيةَ أسلوبية معينة

في بنيتهَه للكثّف عن نو عه.

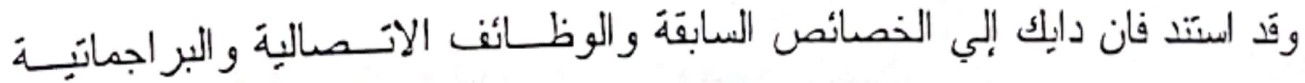
و الوظائف الاجنماعِة في تَسيمِ النصوص إلي عدة أنماط منها: نصوص سـسردية

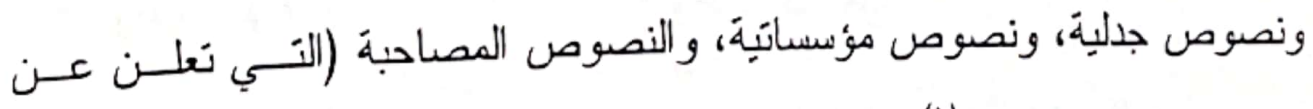

(') مضنون النص ونوعهد)

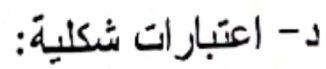

ونعني بها ما بشنتمل عليه النص من رموز أو علامات معجميــة، أو أبنيــة

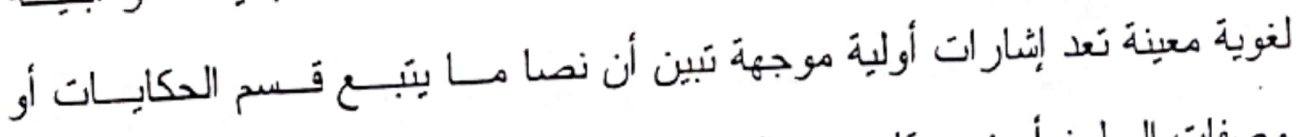
وصفات المطبخ أو نص قانوني...الخ.

" وقدعد فولفجانج هذه الأشار ات منطوقات نمطية أو مبــادئ نــنظم أو قو اعــــ أو توصيات تشكيل تشبر إلي نوع النص، ومن هذه الإشارات أبنية ممبزة في بداية

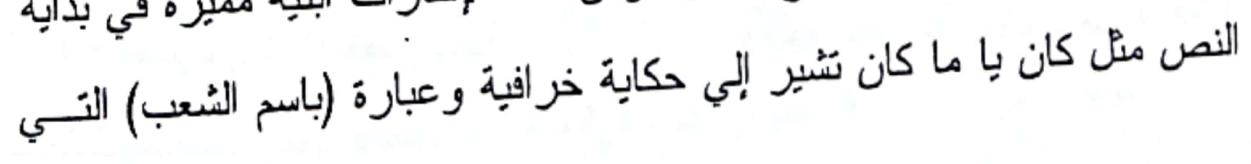




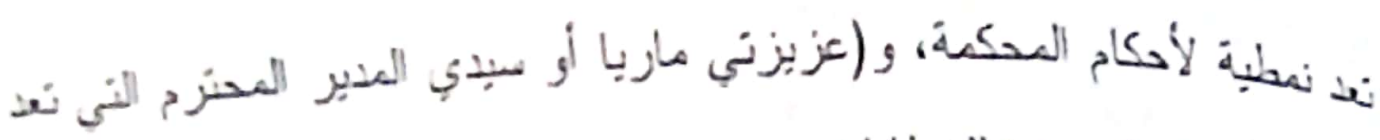
إنار ات افتتاحبة معبز ة للخطابات.

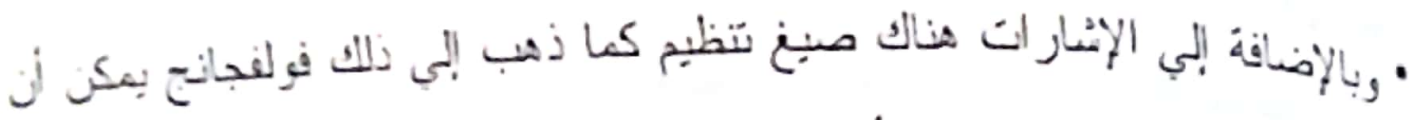

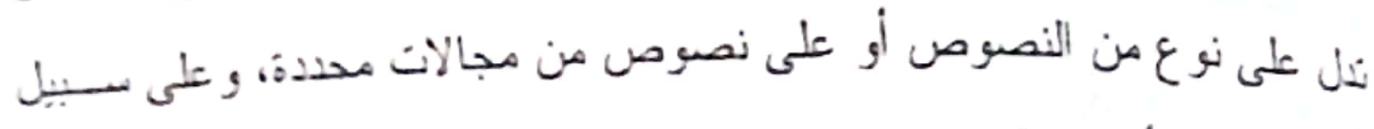

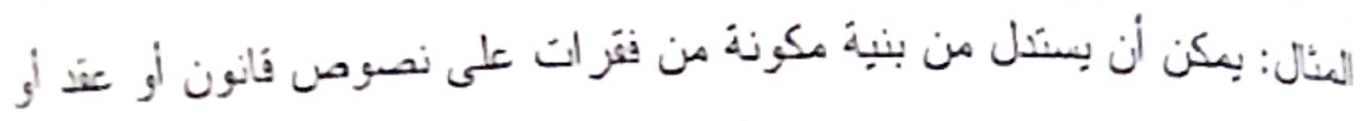
غنبر ذلك وكألك من بنبة مكونة من أشطر على نصوص شُعربة، ومن شانـات

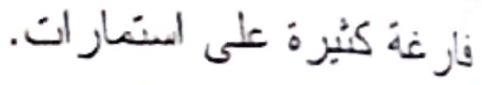

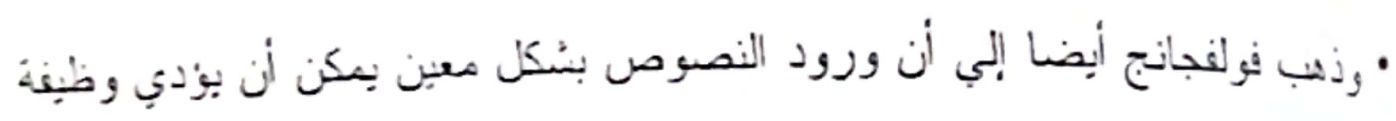

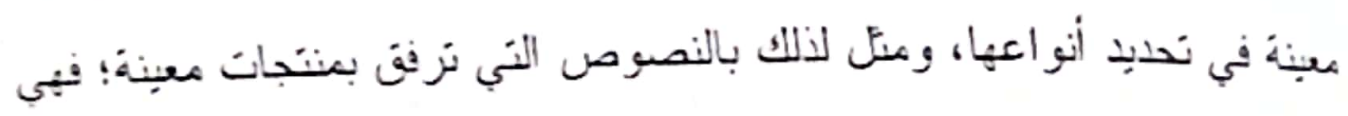

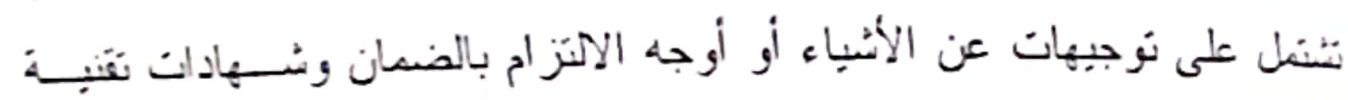
وغنير ذلك.

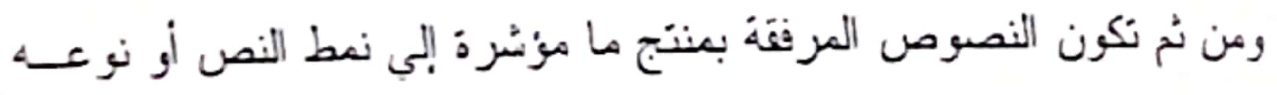

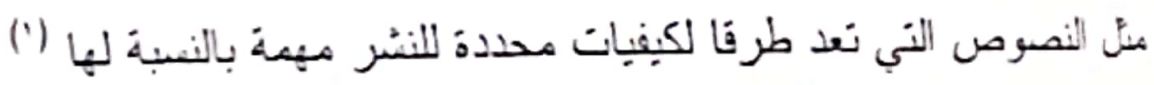

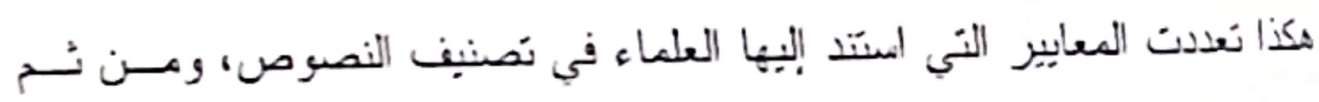

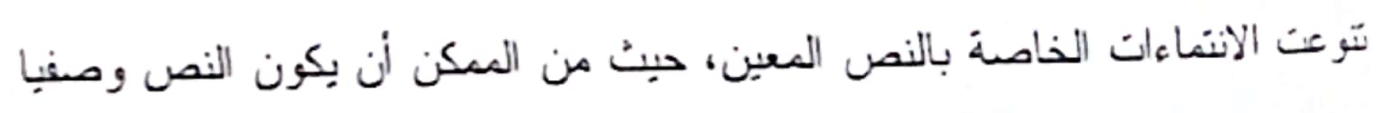

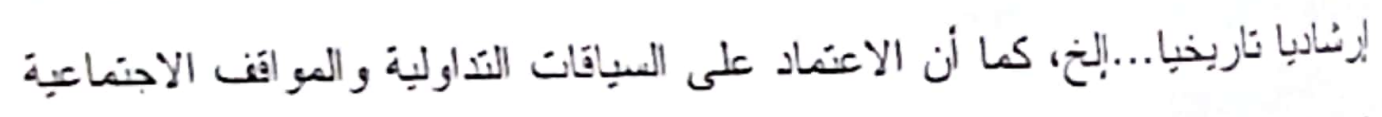

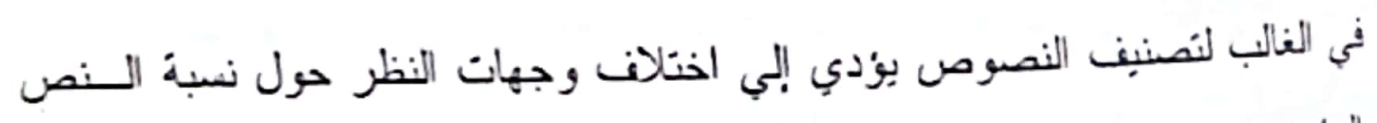

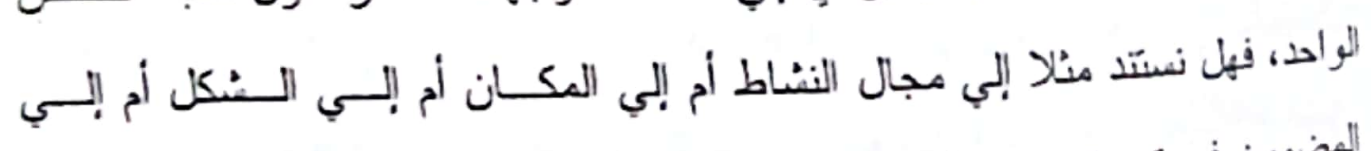

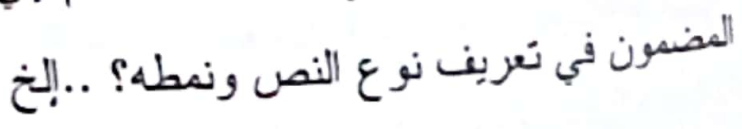




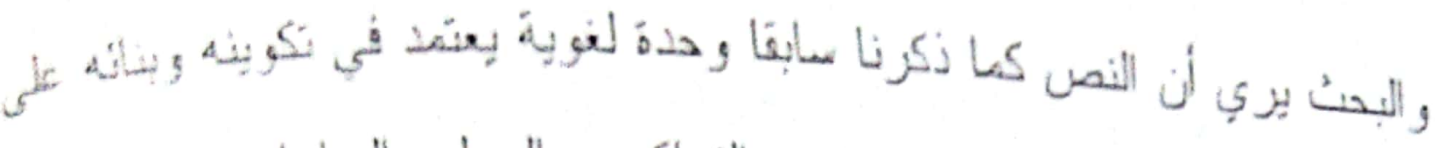

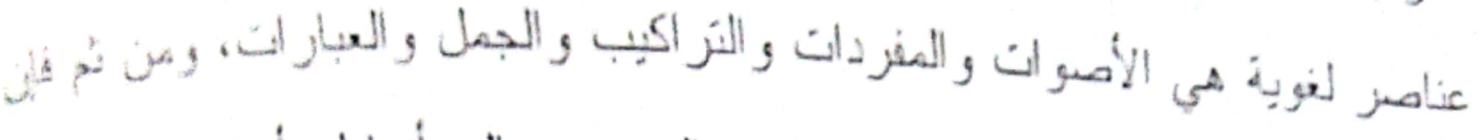

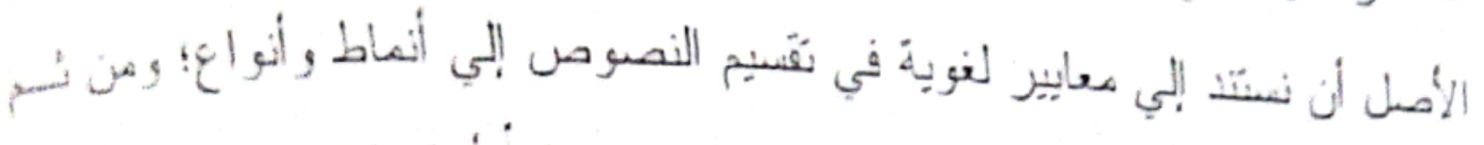

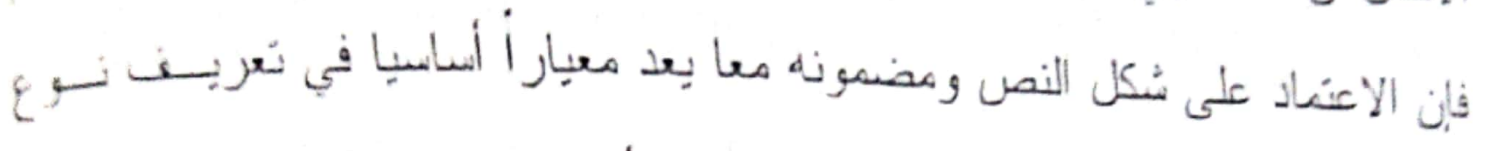

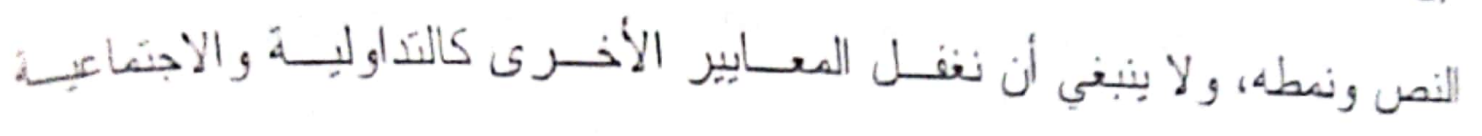

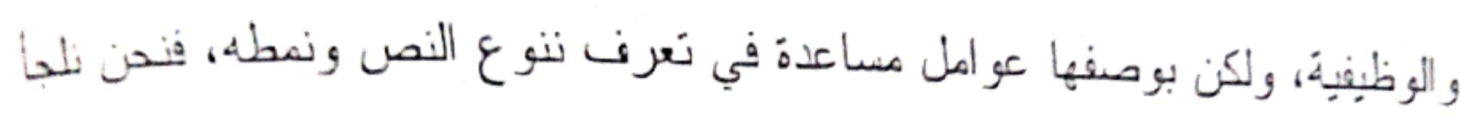

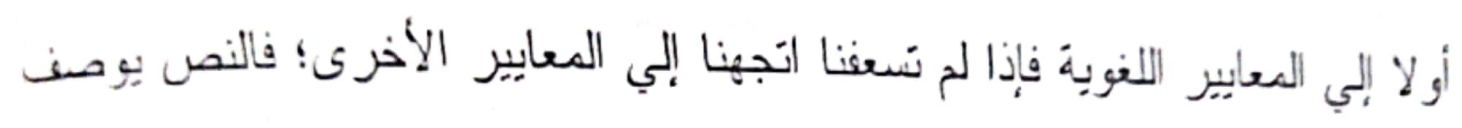

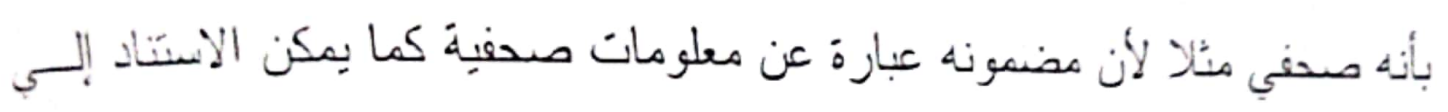
ككان النص في النعرن على أنه نص صدفي لأنه كتب في الصديفة مثّلا.

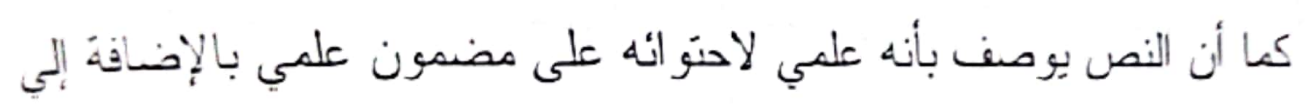
النتاء ألفاظه ومفرداته إلي معجم الألفاظ العلمية.

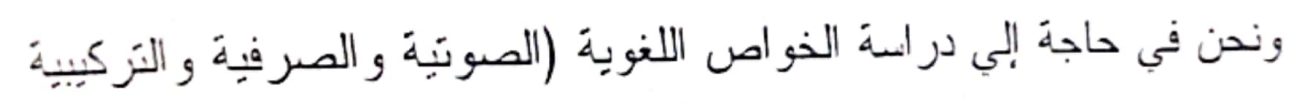

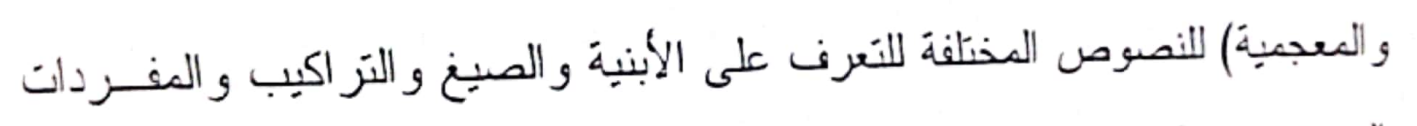

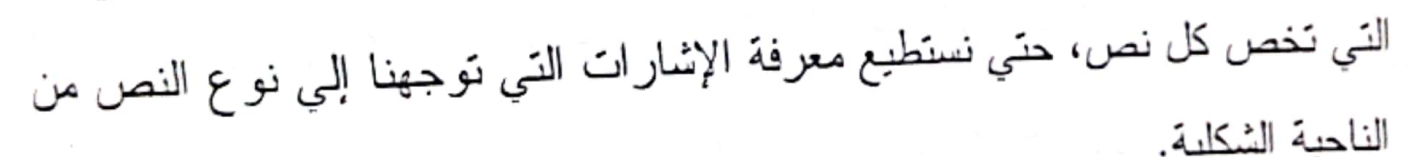
الناحية النكلية.

\section{ه- طرق التحليل اللغوي للنص:}

بيثل النص وحدة لغوبة عضوية بين أجز ائه أو وحداته تماسك وتر ابط، وللكثيف

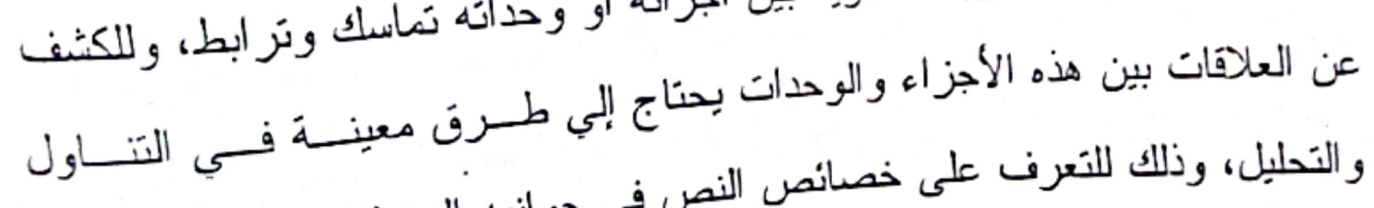

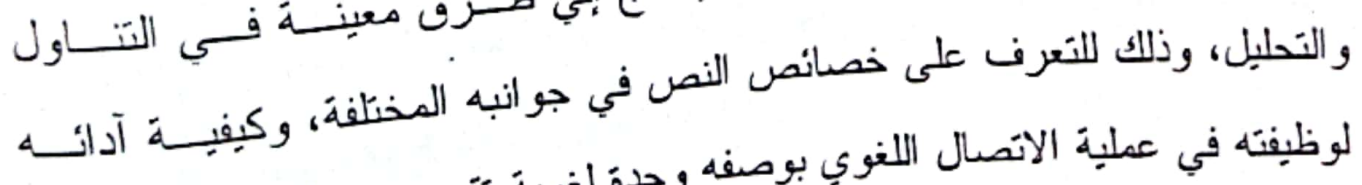

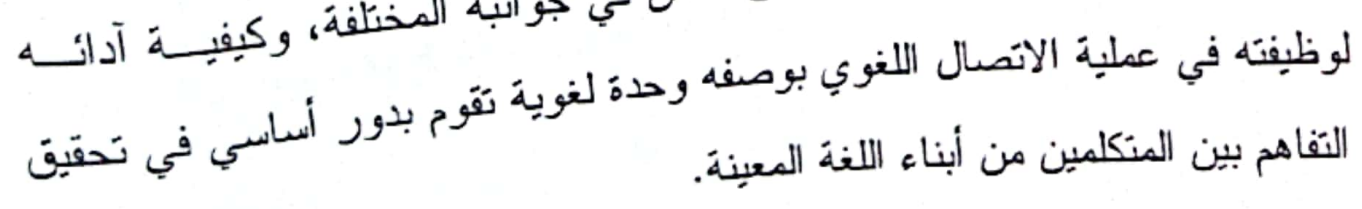
التفاهم بين المنكلمين من أبناء اللغة المعينة. 


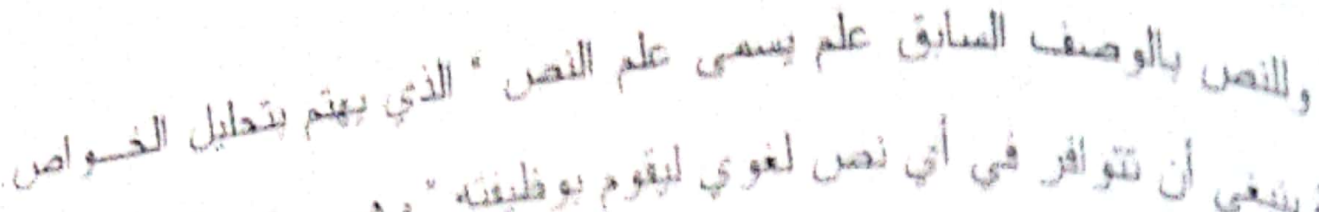

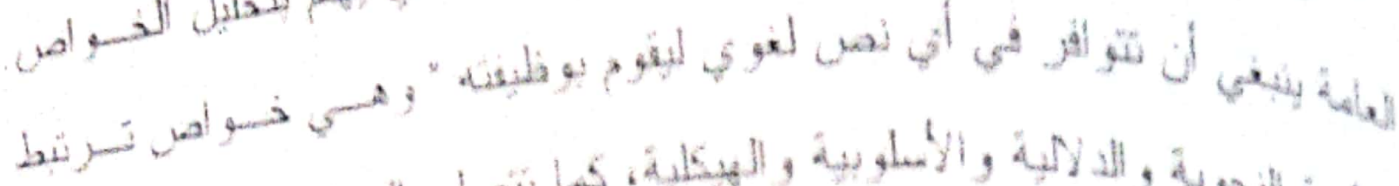

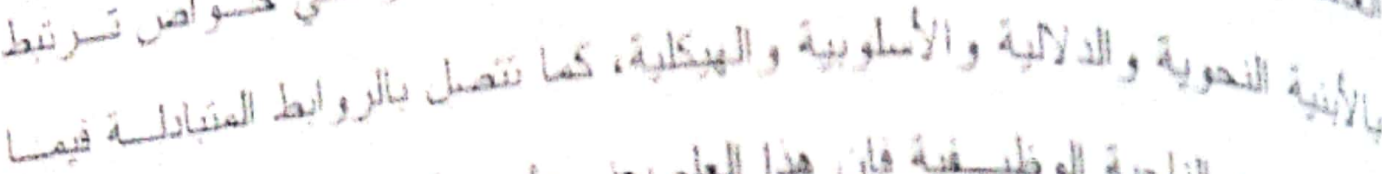

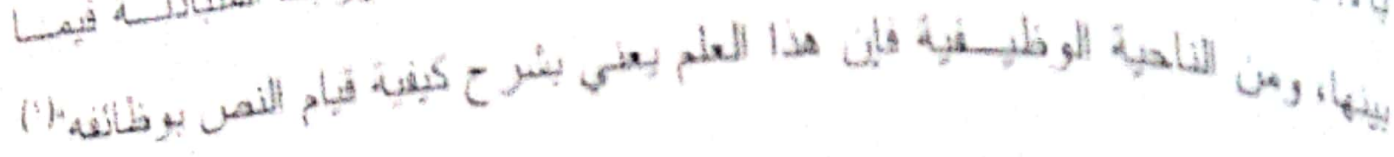

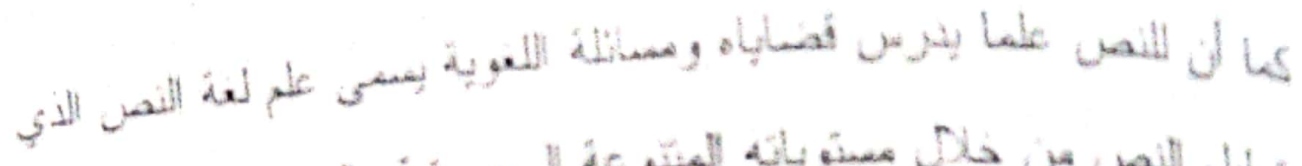

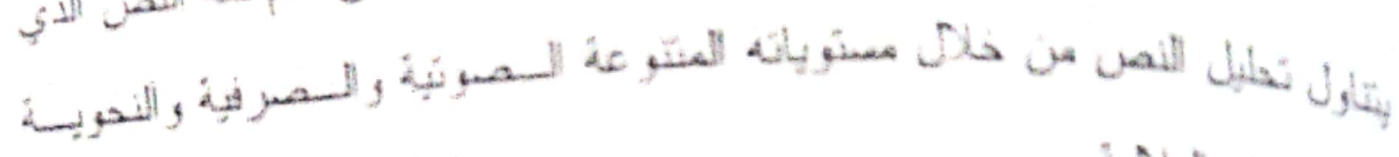

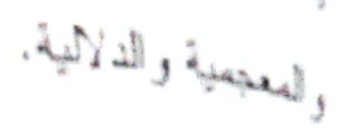

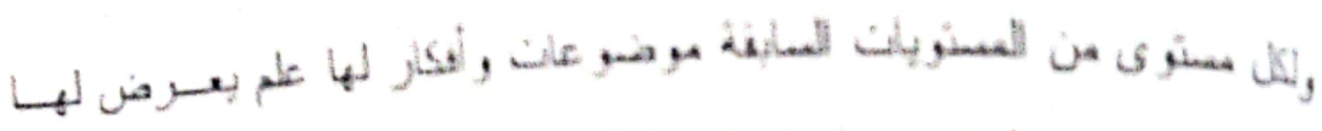

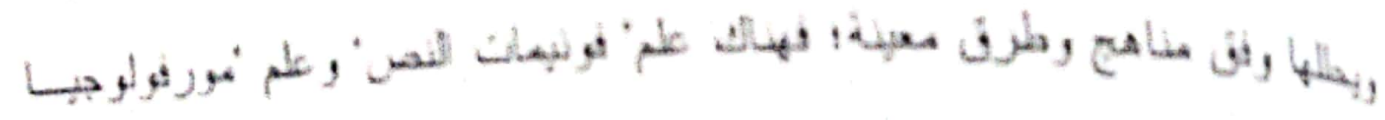

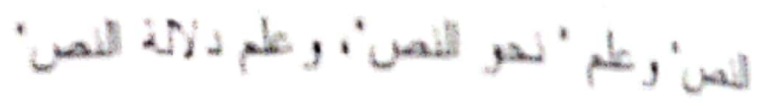

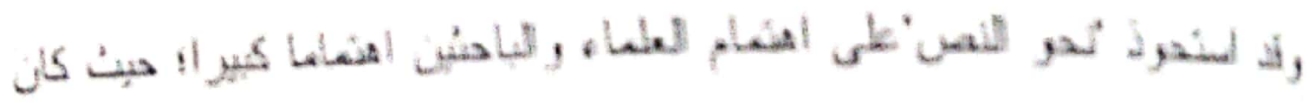

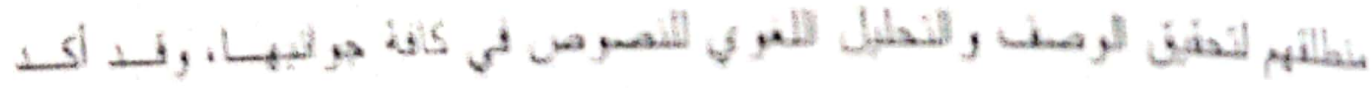

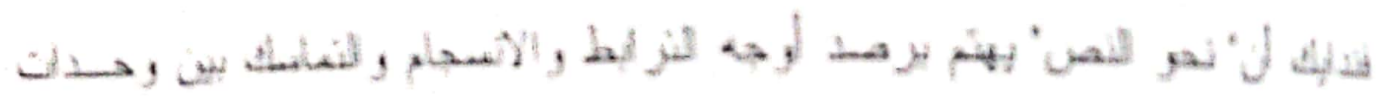

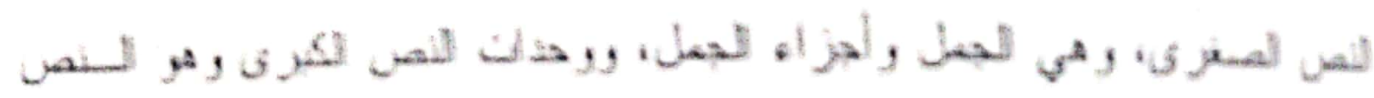

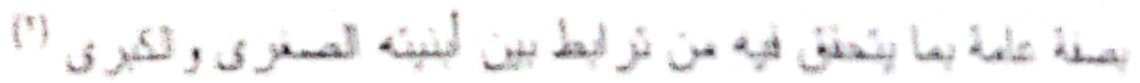

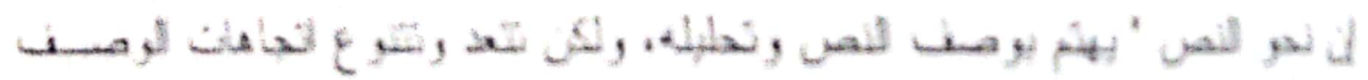
atis,

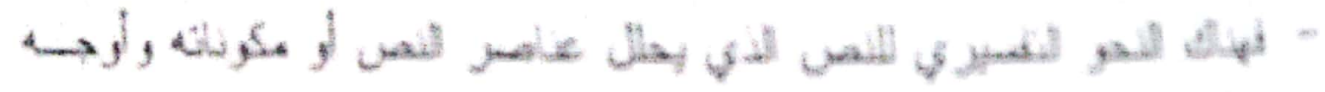

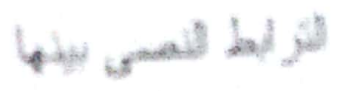

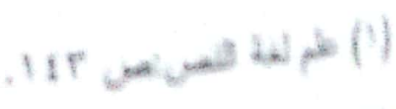

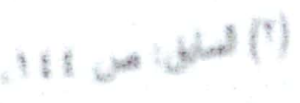




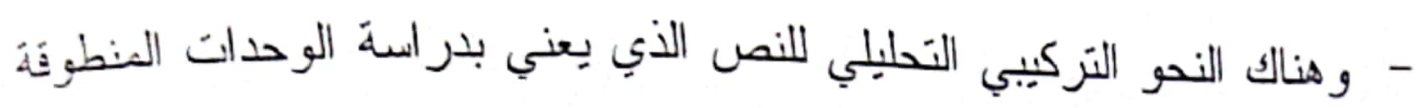

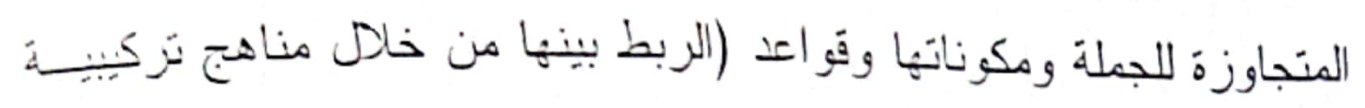

\section{(1) نحليلِية}

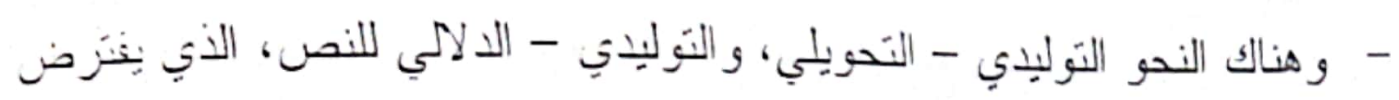

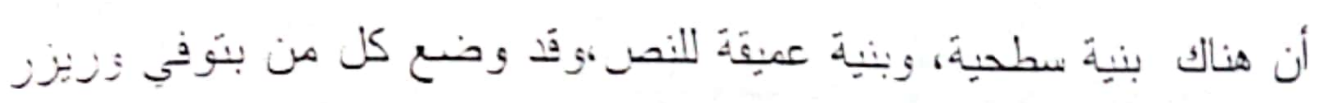

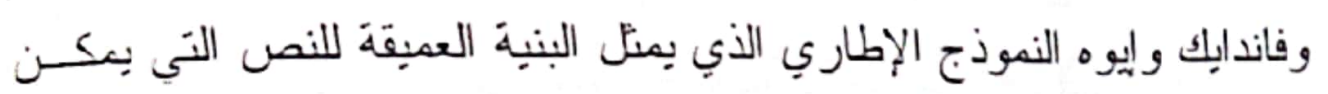
أن بِستق قَو اعد لبنائها

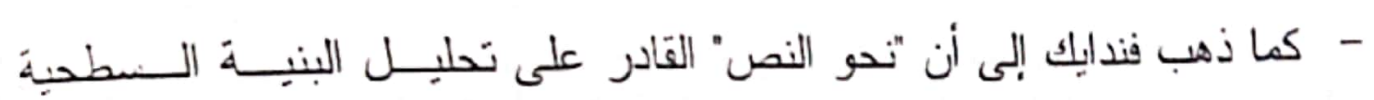

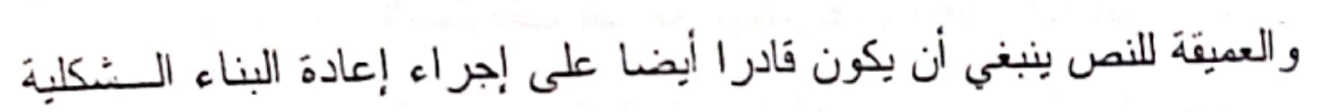

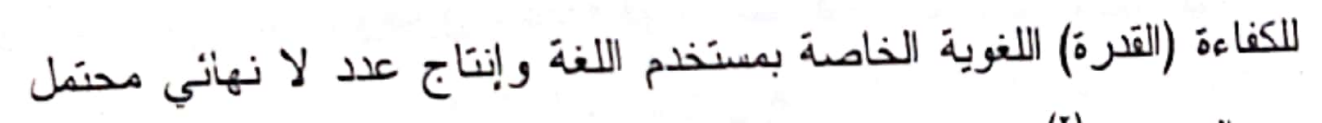
من النصوص(')

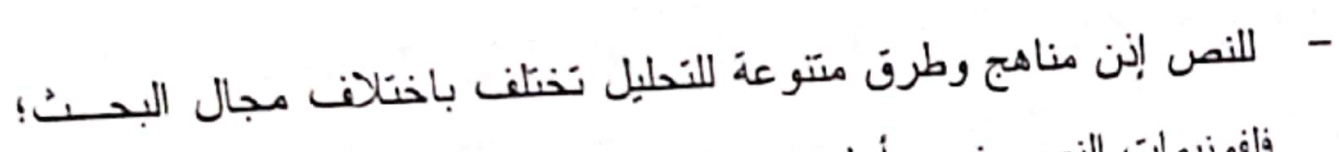

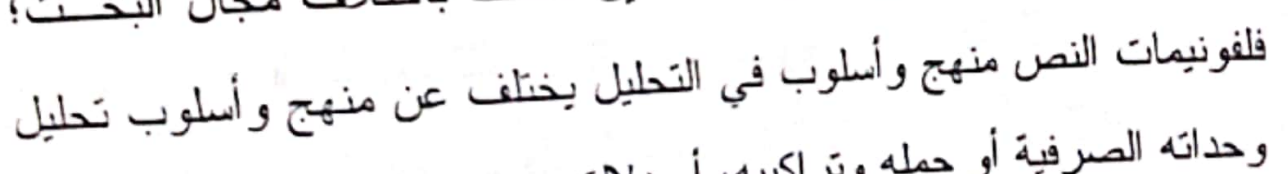
وحداته الصرفية أو جمله وتر اكيبه، أو دلاتله

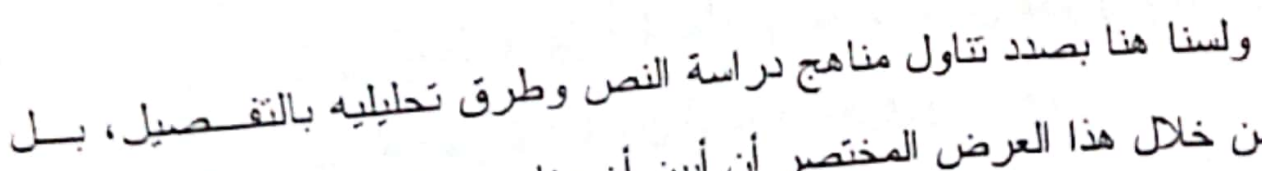

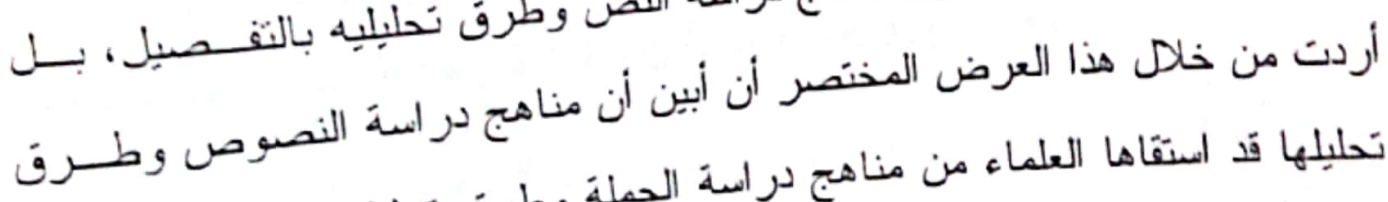

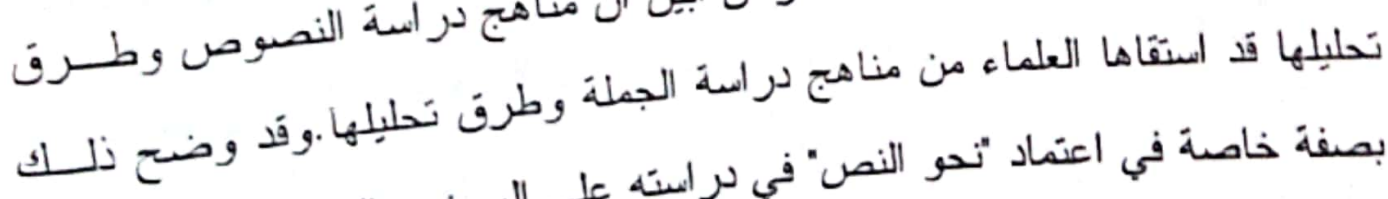

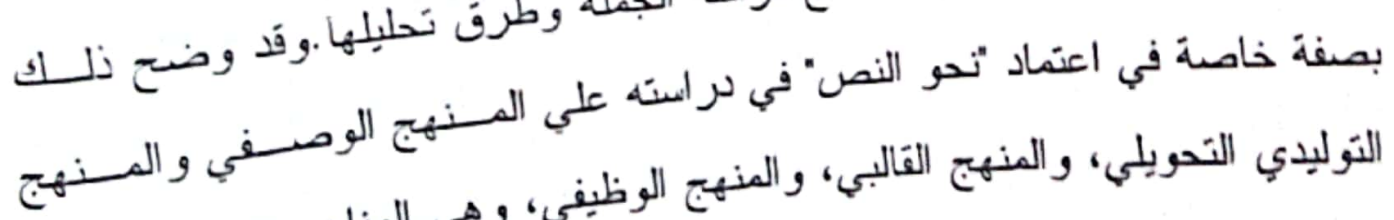

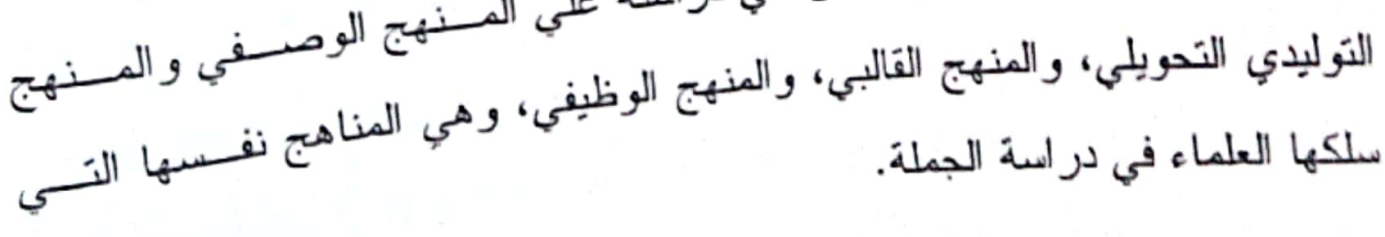
(1) السابق: ص .10 - 101.

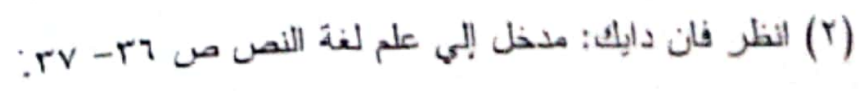




\section{المبند المانس}

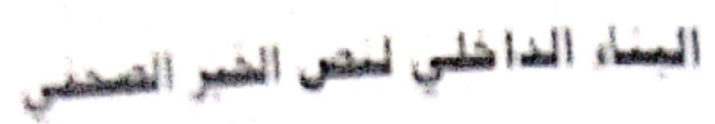

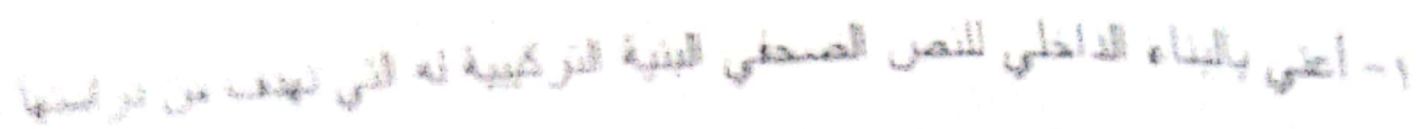

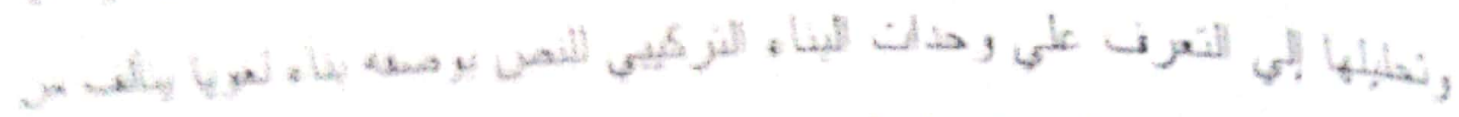

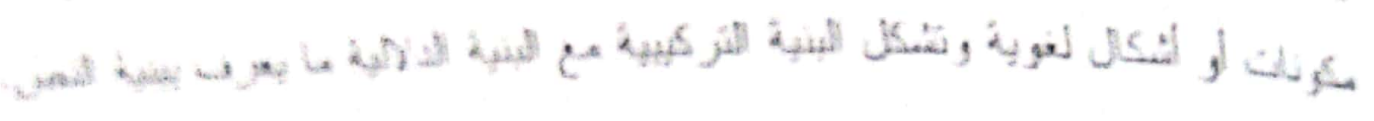

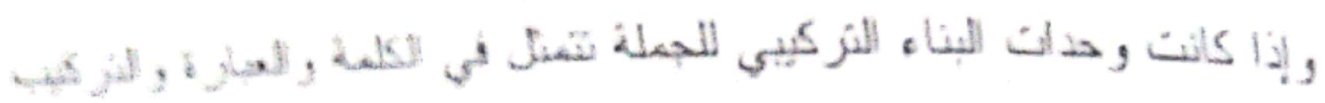

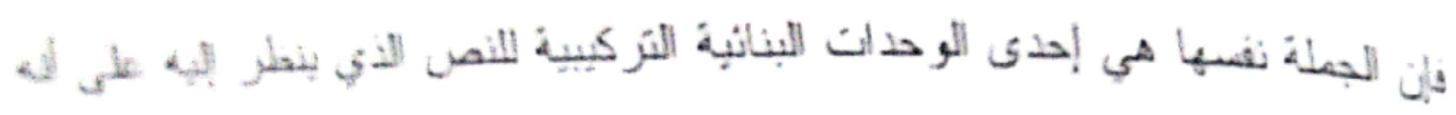
متالية جلية خطبة منصلة بين مكوناتها نماسك وئز ابط. ومن هذه المتو البة الجملية تتألف وحدة أخرى من وحدات البناء التز كينسي

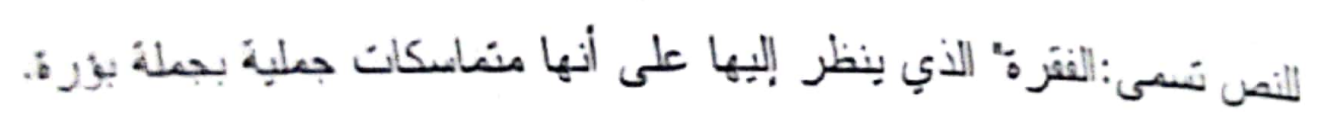

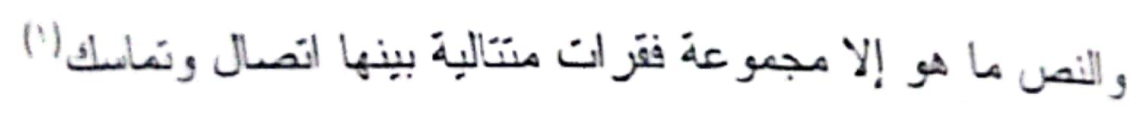
هذا التز ابط و التماسك والاتصال بين الفقرات هو الذب بجطنا ننظر إلبها على

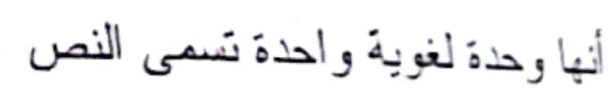

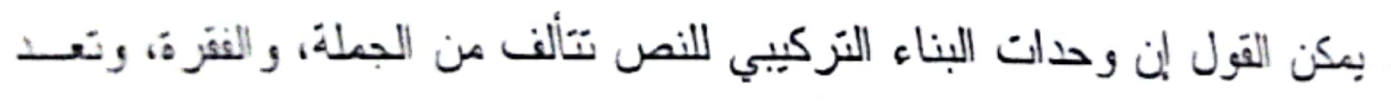

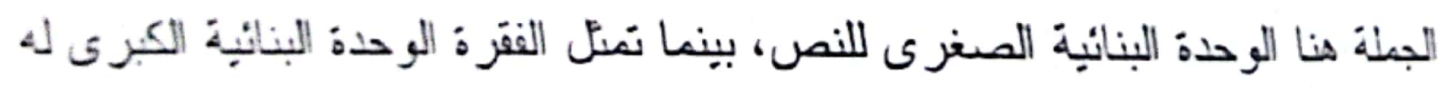
والعلافة بين الجملة والفقرة والنص علاقة وثيُقة؛ فمن الجملة تَألف الفقرة، ومن

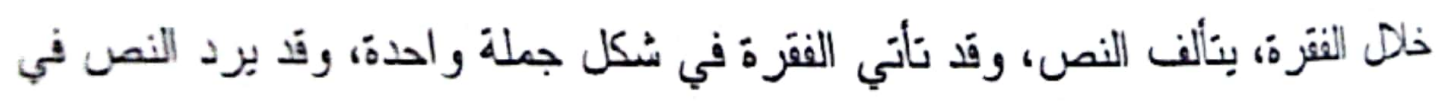
صورة نقتة واحدة.

(') الظر د. عمر محد أبو خرمة: نحو النص ص I.r. 
وقد أكد فندابك أن تصور البنبة الكبرى للنص لا يُّدي إلي صسرة النمسك

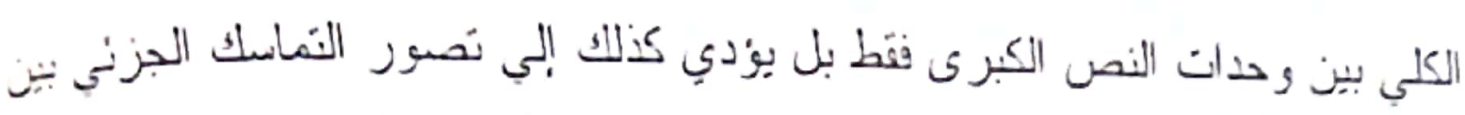

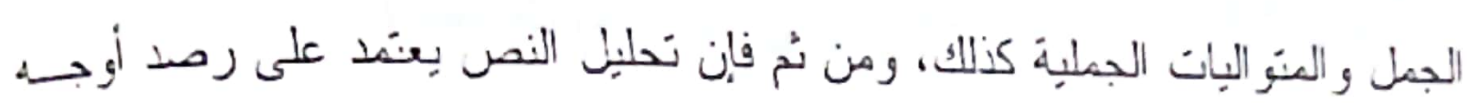

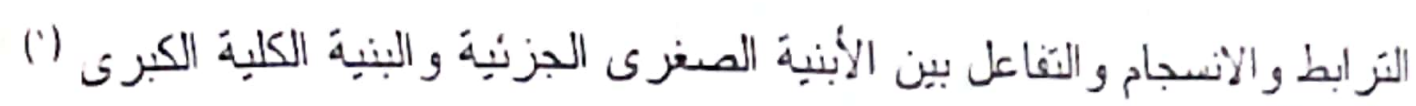
r- ويكن أن نترن على خصائص البناء الاخلي لنص الخبر الصحفي من خلا جانبين الأول: النُكل و الثّاني: المضمون الأول السُكل ونمرض من خلاله للأمور التّالية: أولا: خصائص نص الخبر الصحفي عامة

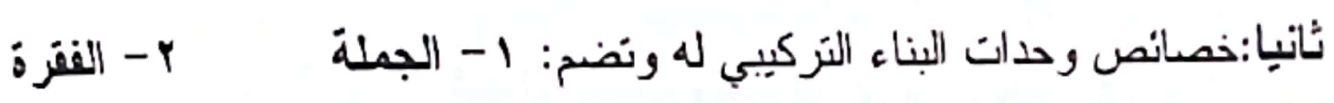
أولا خصانص نص الخبر الصحني عامة:

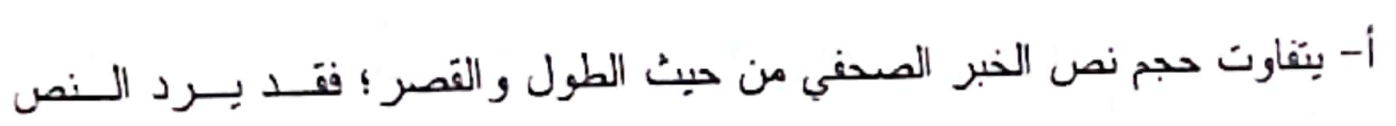
قصنير امؤلفا من فقرة واحدة عبارة عن جملة واحدة ومناله:

بدأت شركة هصر للطبران أمس تطيق الزيادات الجديدة لأسعار تــذاكر

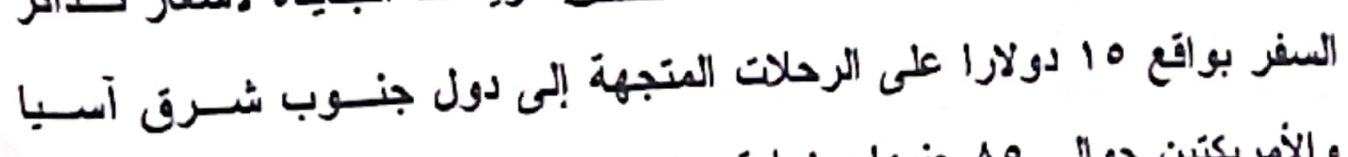

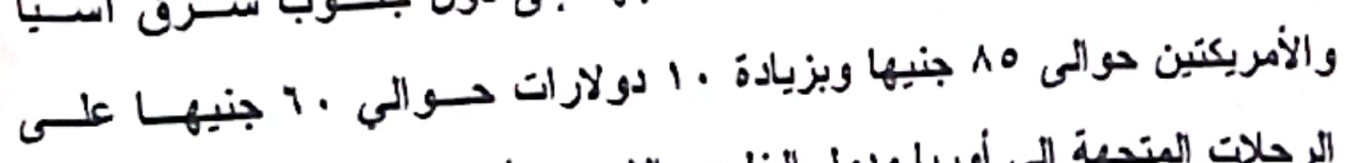

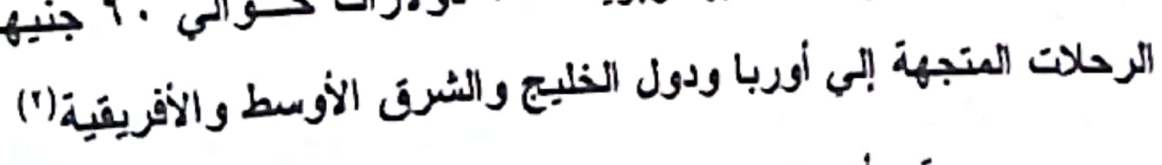

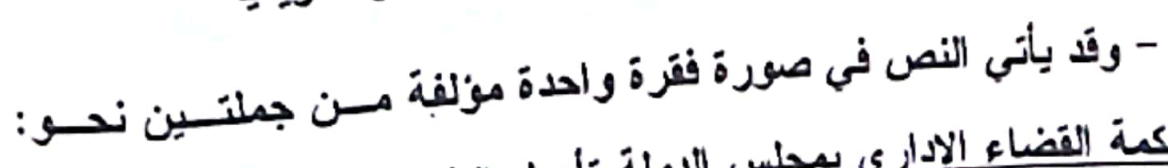

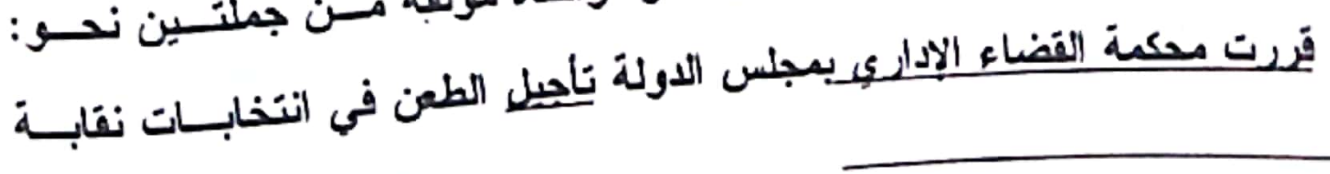

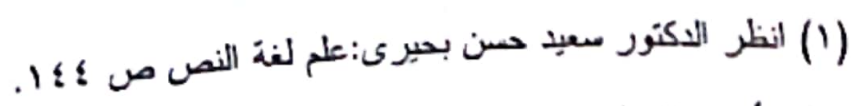

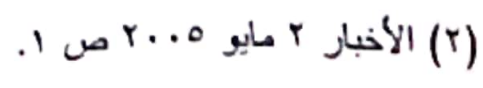


المحامين العامة التي أجريت في شُهر مارس الماضى لجلسة بع مسايو النّادم.

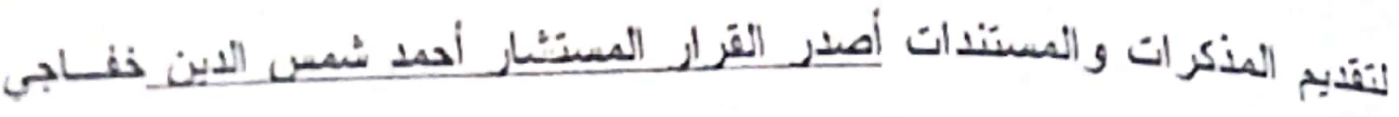
نائب رئيس المجلس بوضوية المسنتشارين الاكتّر سامى عبلد وصفوت الفتــ وصبدى العجىى و عاطف السعدي نواب رئيس المجلـس بأمانسة سـر محمـــ

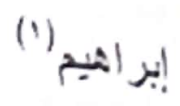

- وقد يأتى النص مكونا من فقرة واحدة تشتمل على أكثر من جملتين

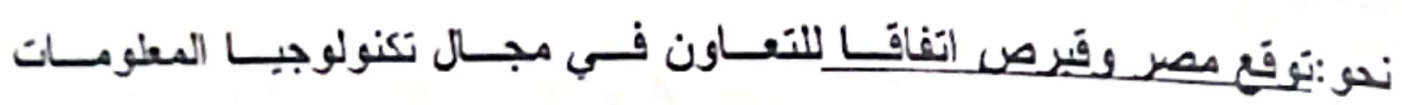
والاتصالات...وصرح السفير محمد عبد الحكيمسفير مصر لاى قبرص بان المزير سيجزى...كيا بلتقى لالبكاس بوزير السياحة أحمد المغربي...وأضـان السـفير

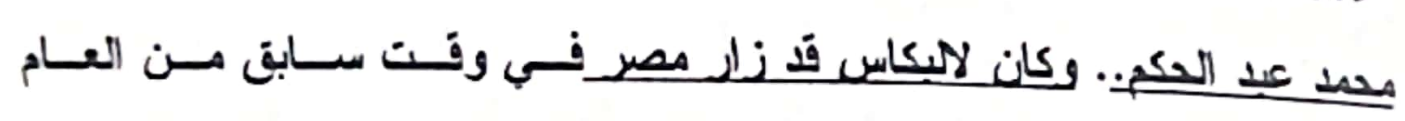

\section{(الحلمي... (1)}

- مقد برد نص الخبر الصحفي في أكثر من فقرنين قد يكون ثلائا أو أربعا أو

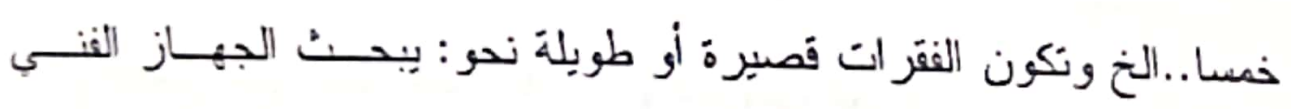

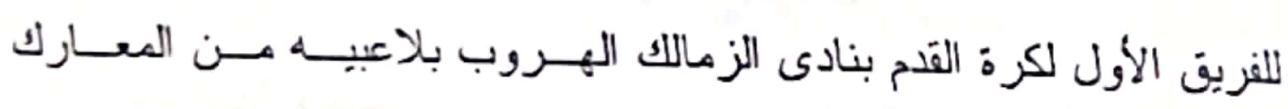

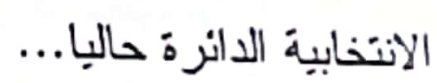
- كان أحمد رفعت مدير الكرة قد أكد حاجة الفريق... أكد أحســ رفهــت أن

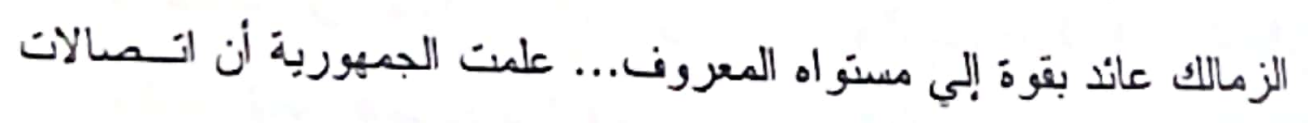

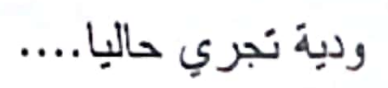

وفي الغالب يكون نص الخبر الافتتاحي للصحيفة طويلا أبا كان نوع الصحيفة.

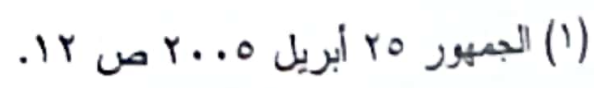

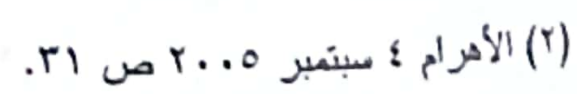


ب- بانتي نص الخبر الصحفي سو اء أكان طو بلا أم قصير ا في شُكل مكون هسن

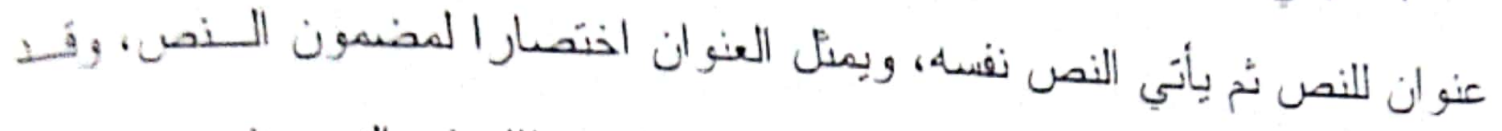

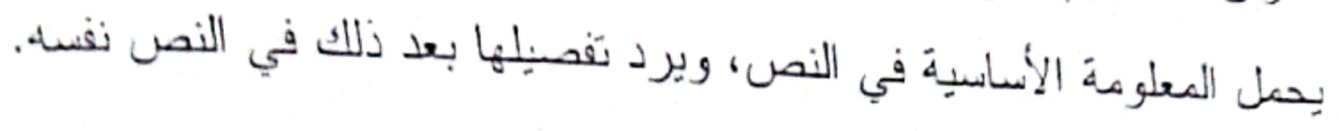

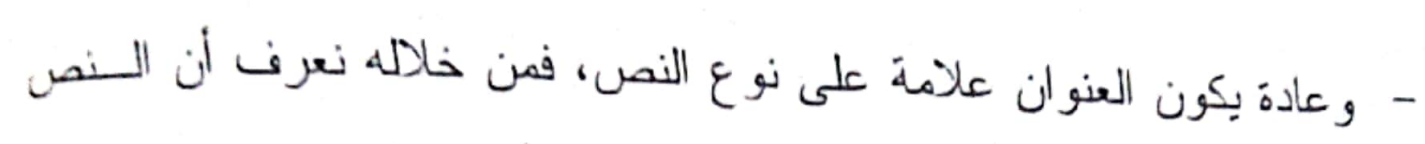
نص اقتصادي أو سياسي أو علمي أو اجنماعي أو رياضي...إلخ علئ

\section{فالعناوين التالية:}

$$
\text { - مبارك بلتَّى بالرئيس الفلسطيني في سرت. }
$$

- - أبومازن تقدير كامل لجهود مصر من أجل إتمام الانسحاب الإسر ائيلي - بعد قرن من تصنيعه الاسبرين مفيد لسرطان الأمعاء - البرلمان الأوروبي يسنضيف أول مؤتمر للاستّمار و التجارة بمصر - - مومبارسا أمريكيا من أجل "أماكن في القلب" - - القبض على تاجر المخدرات قاتل الشرطي السري

- بعد اختياره منسقا بين مجلس الإدارذ وجهاز المنتخب الأول: رئيس اتحساد

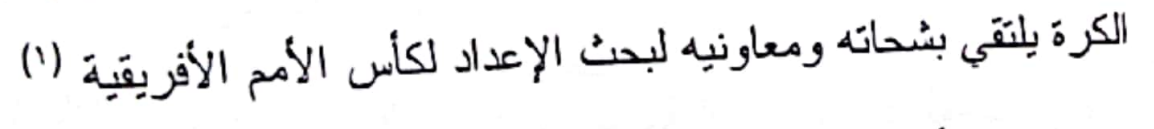

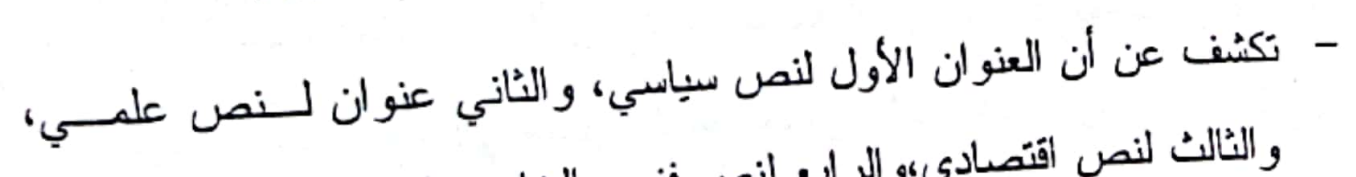

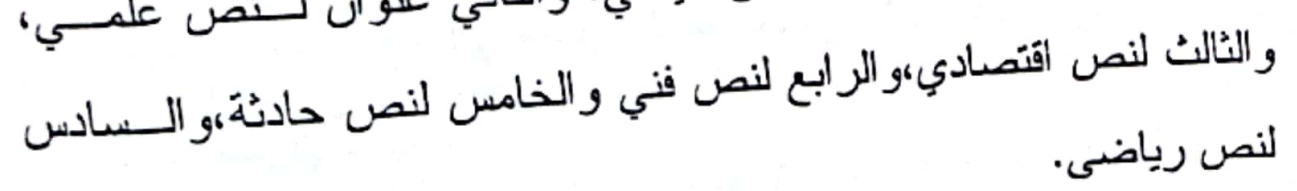

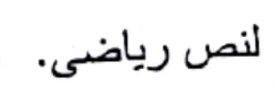




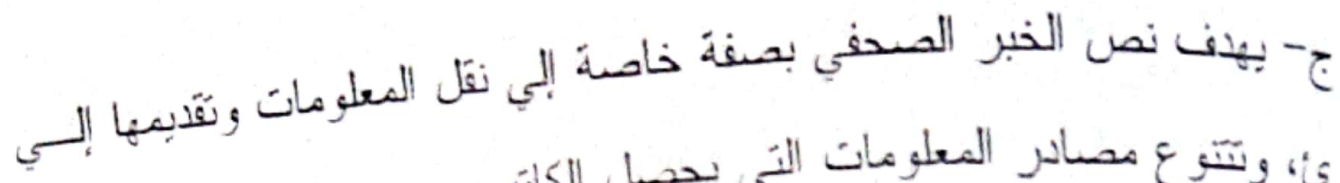

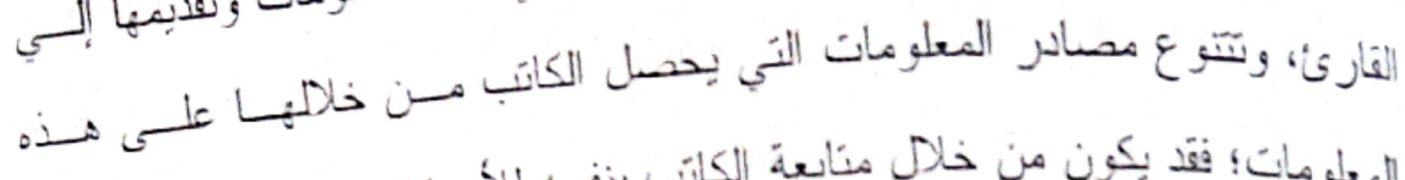

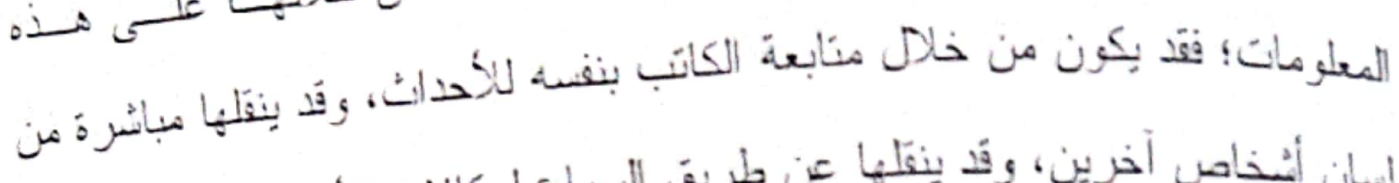

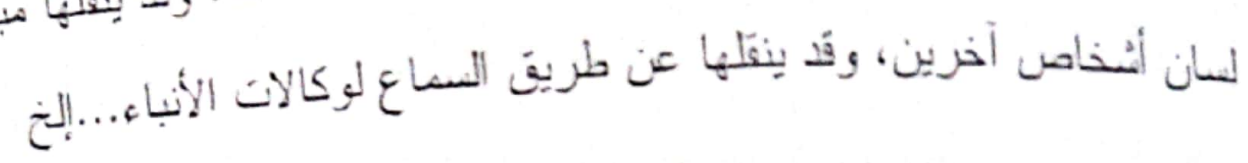

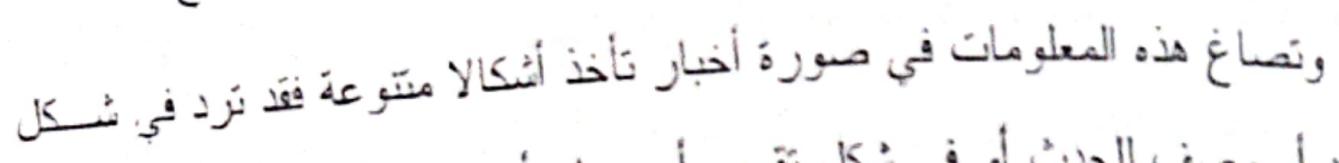

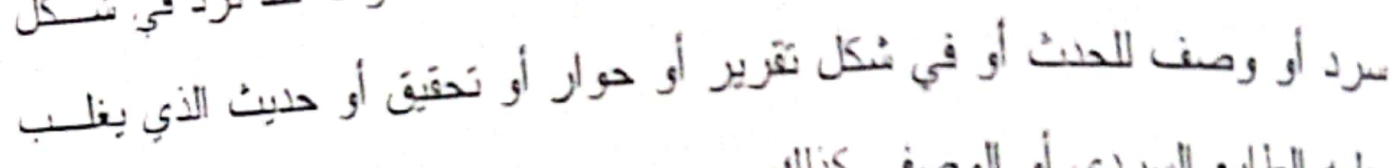
عليه الطابع المردي أو اللوصفي كنلك.

ومن نُ فإنه بعكن نصنيف نص الخبر الصحفي إلي نو عبن: الأول السنص اللمردي و الثُاني النص الوحفي.

ويكمن العامل الأساسي في تَّبم نص الخبر الصدفي إلي النوع المردي أو

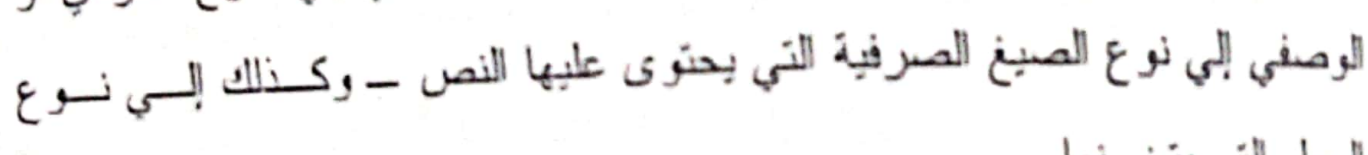
الجمل اللي بينخمنها.

فيكون النص وصفيا إذا كنر لسنعل الجمل الاسمبة والجمل الفعلية النـي

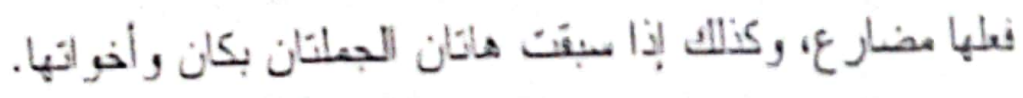

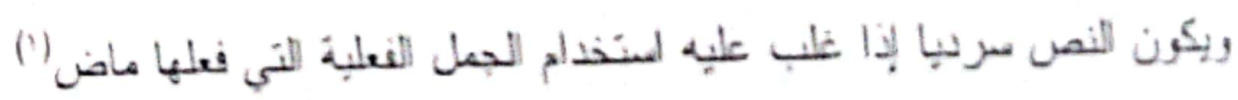

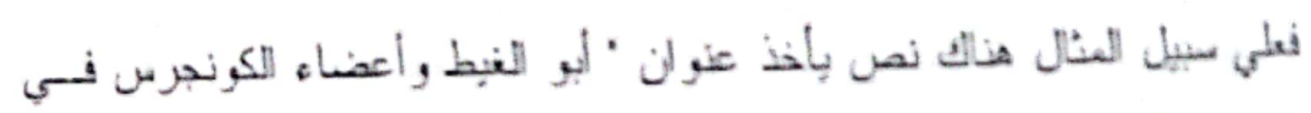

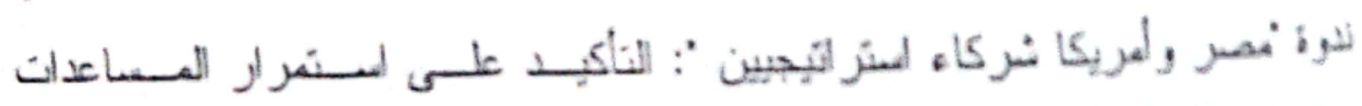

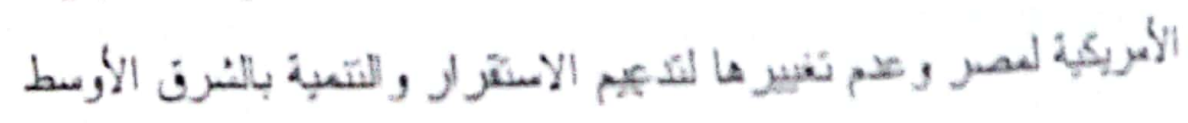


وقَّ جاء النص نفسه طويلا مكونا من إحدى عشرة فقرة، الهتم فيهيها الكاتب بنقل ما جزى في الندوة من خلال سرد كلمات الهشاركين في الندوة فجاءت غالبية

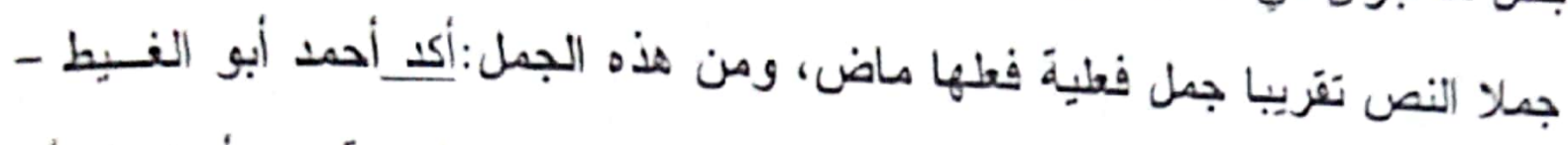

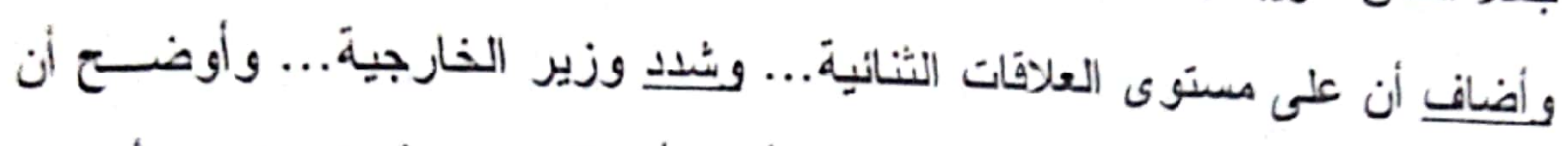
هصر.. ودعا أبو الفيط.. وفي هذا السياق أنثار أبــالغيط...وفيما يتعلق بالأوضاع

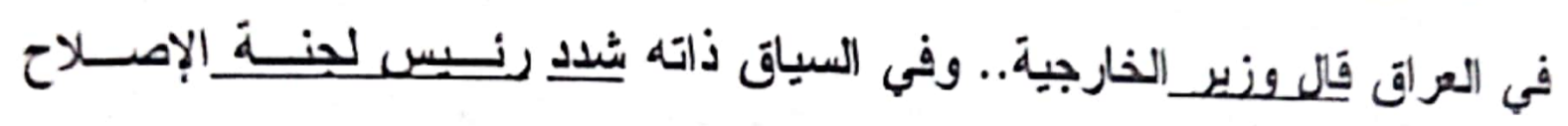

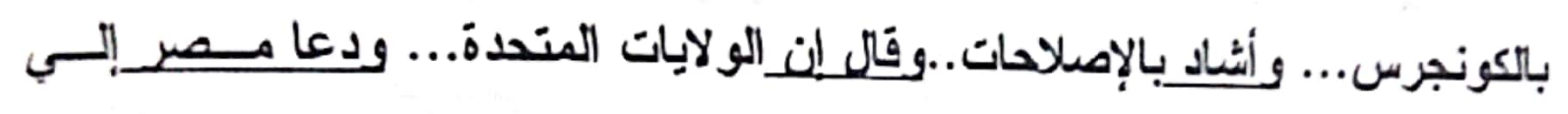
ضرورة... وقال لنـمصر لايها مقومات... والتقط الدكتور حسام بذراوى..... وقَّل

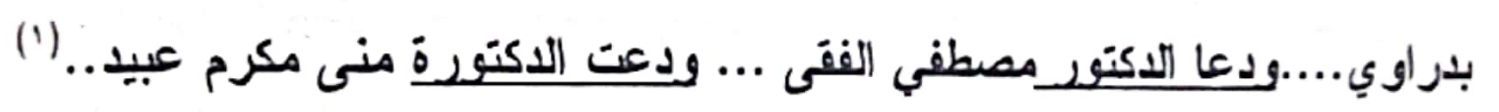

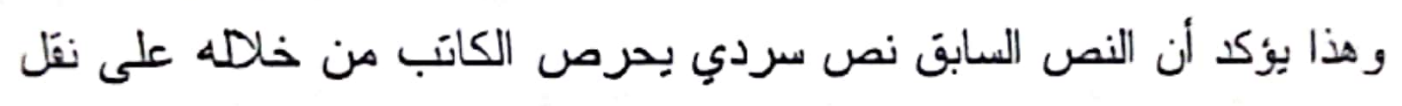

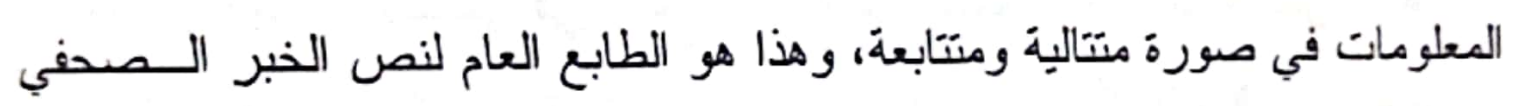

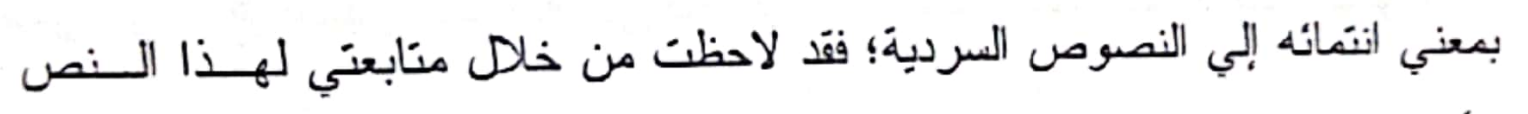

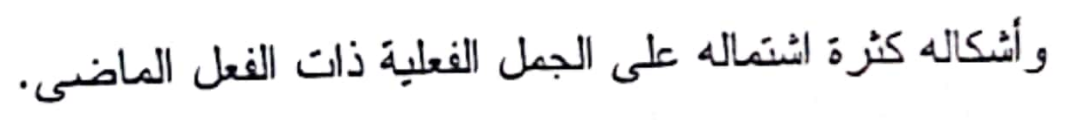

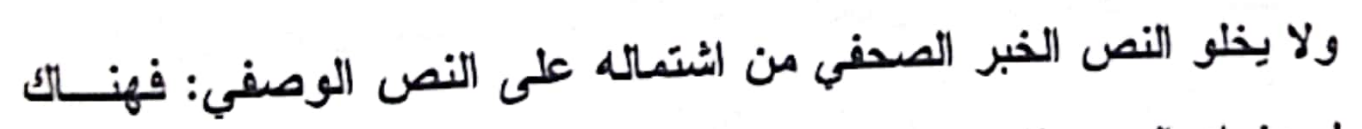

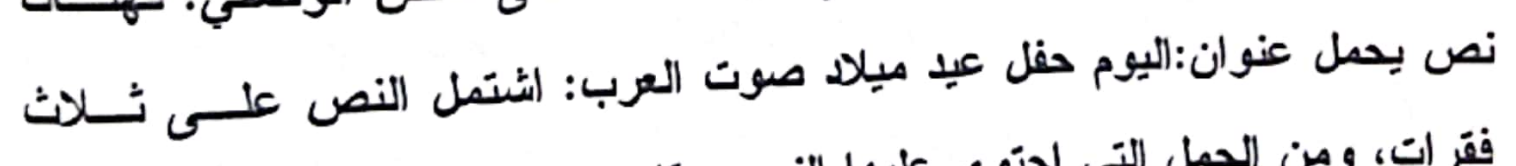

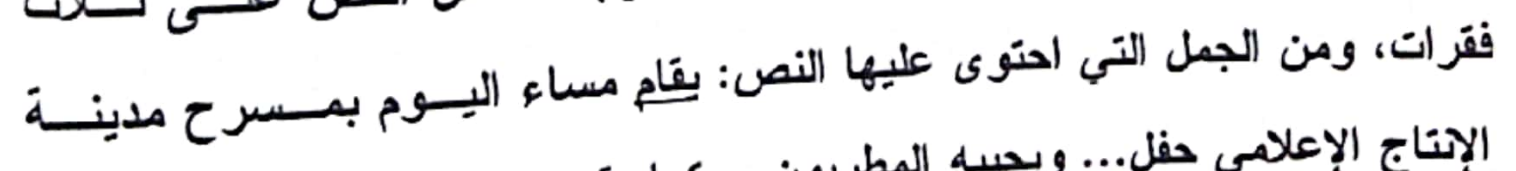

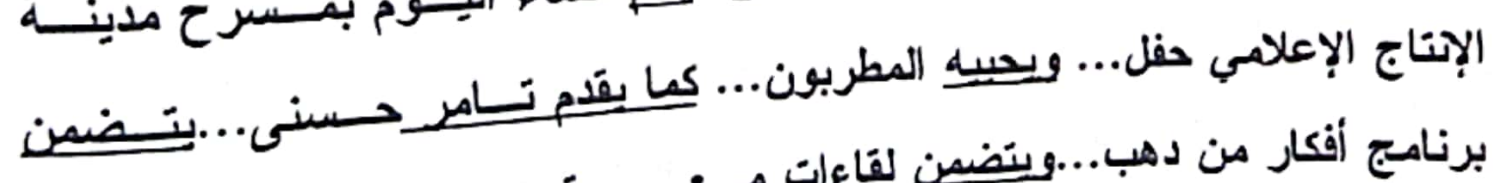

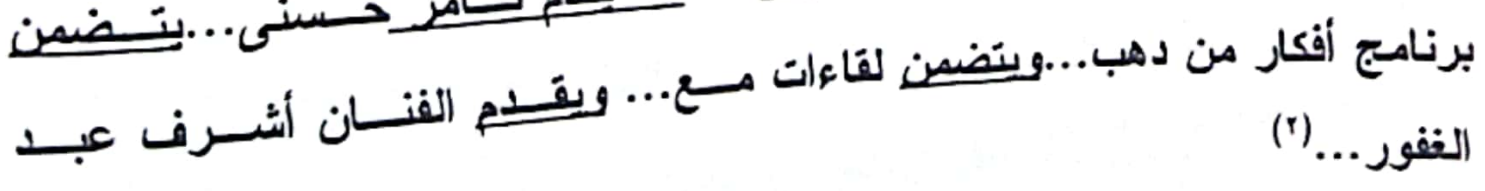

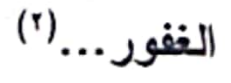

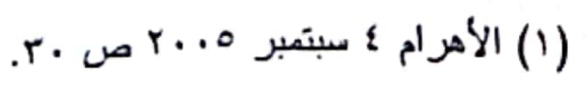

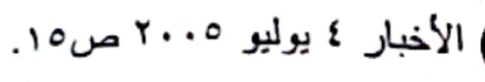




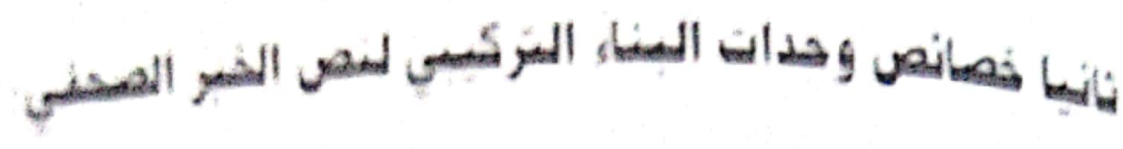
1- الجبة:

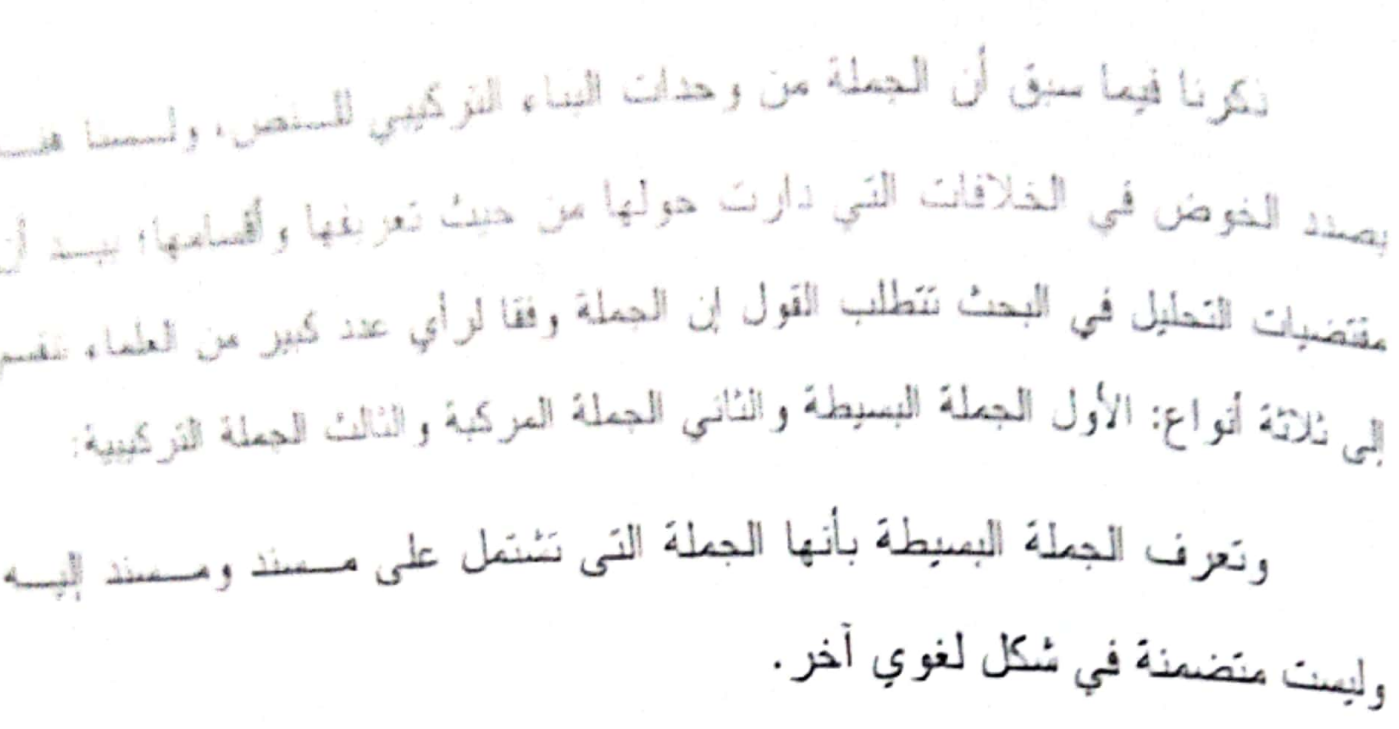

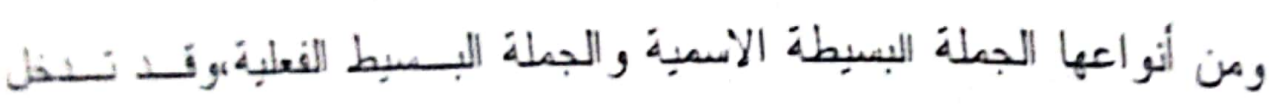

$$
\text { الأئوات على هذين النوعين. }
$$

أها الجملة المركبة فهي التي تَألف من جملتبن بسيطنين أو أكثر بربط ببنهيا

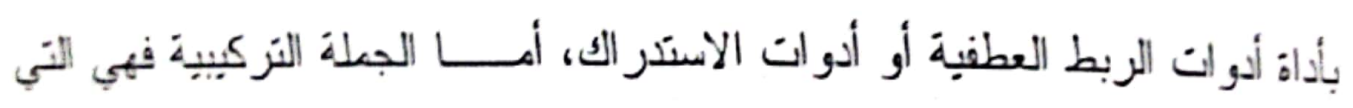
تنكون من طرفين بشغل الطرن الأول بجملة بسبطة ويشغل الطرن الثاني بتركبب ونقصد بالتركيب مجموعة من الكلمات تشنتل على مسند ومسند البيه ونكون مضنة في جملة أكبر. فالتزكيب بنفق مع الجملة البسيطة في التنمال كل منهما على مسند ومسند إلبـ،،

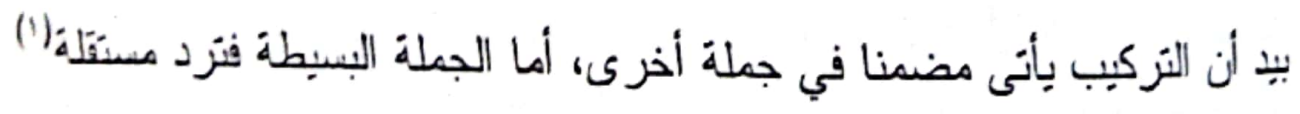

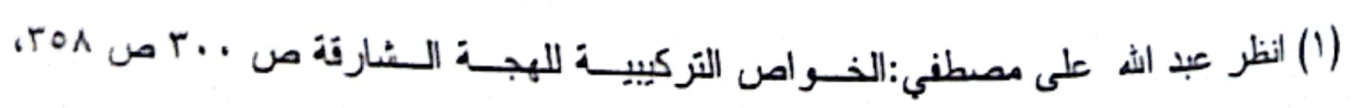
ص . ז. 


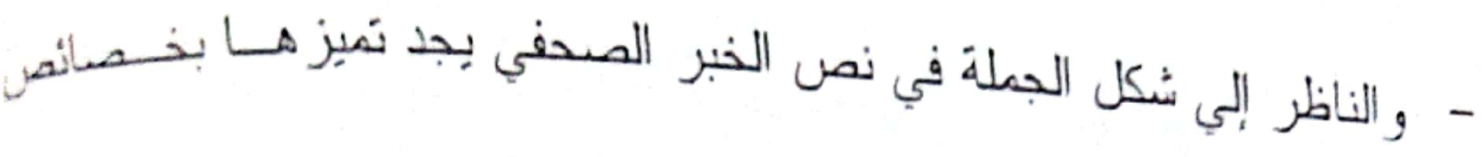
معنية بمكن إيجاز ها فيا يلي:

1- أ: تمتبز هذه الجملة بالطول، ويعود السبب في طول الجملة في نص الخبر

الصحفي إلي كثرة استخدام المكملات و المتعلقات التي ترَبط ب بالعنصرين

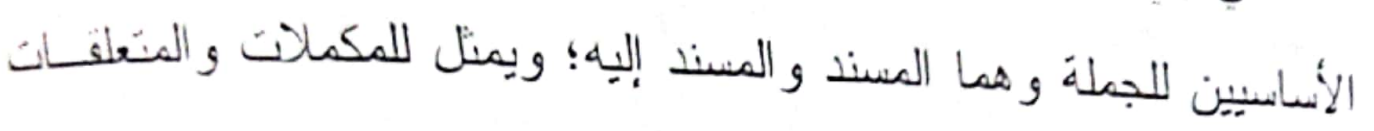

بكثرة استخذام المعطوفات وحروف الجر و الظروف، واستخدام التزر اكيسبـ

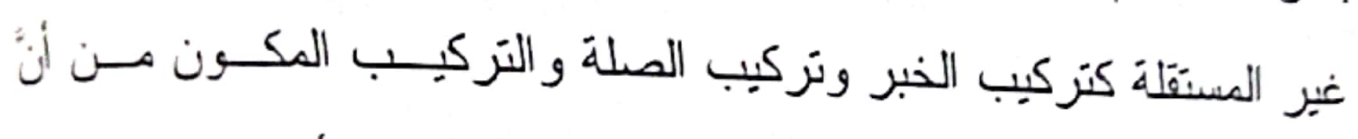

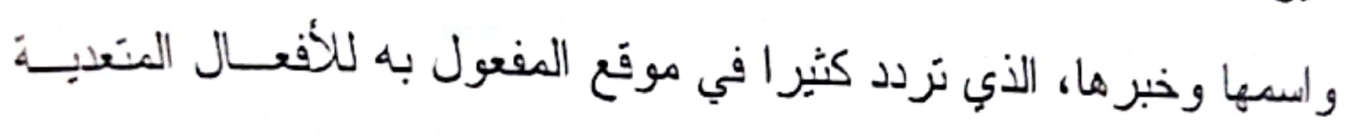

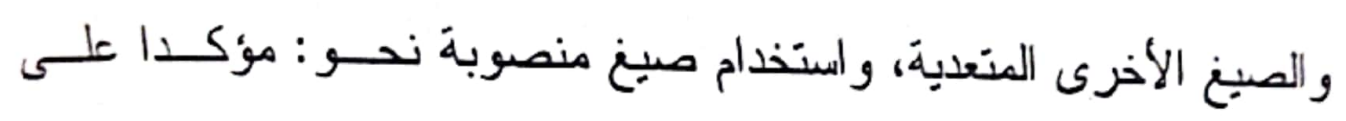
ومشيرا البي، وكثرة استخدام العبار ات المتضامة التي تمثل أسماء للأعـلام والأشخاص والأماكن والهيئات و المؤسسات، وكثرة استخدام النعوت وكثرة المنضابقات. ومن الأمثلة على ما سبق:

وأضاف العقبد أحدـعاصم مدير الإعلام والعلاقات العامة بمرور القاهرة أنذ

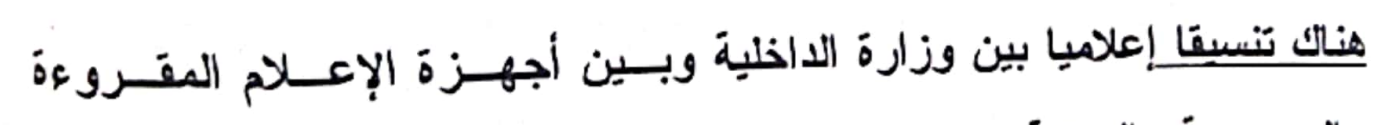

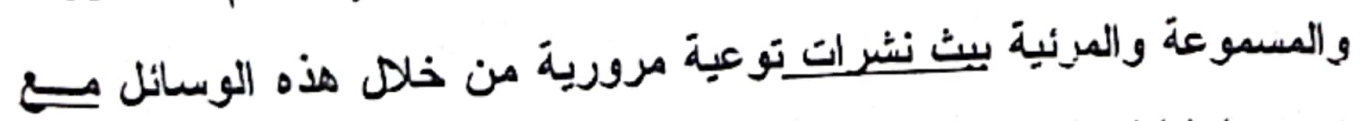

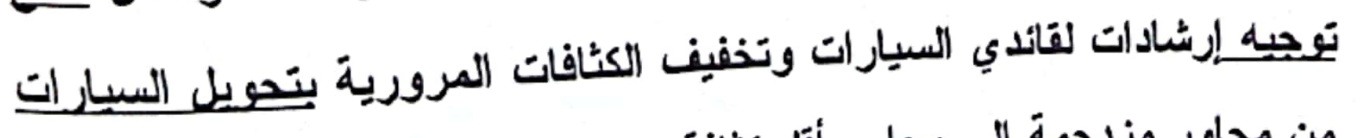

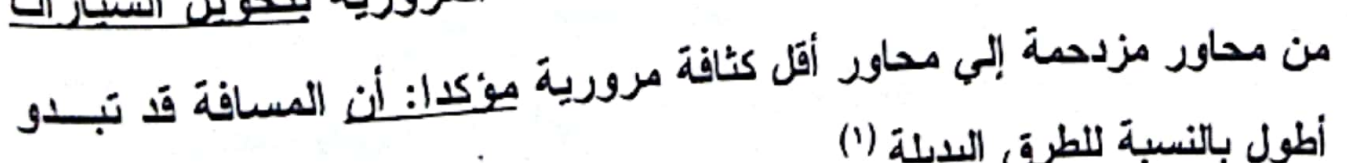
أطول بالنسبة للطرق البديلة (1) 


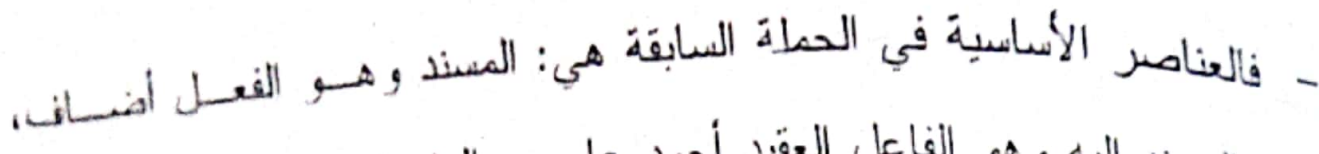

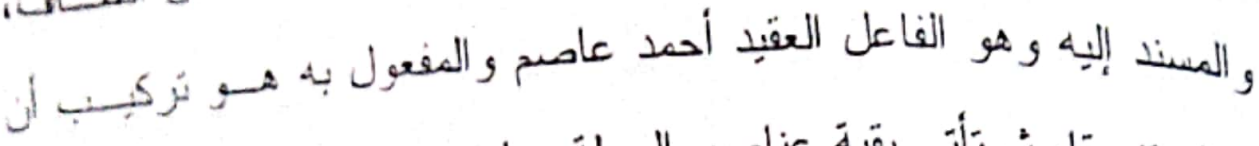

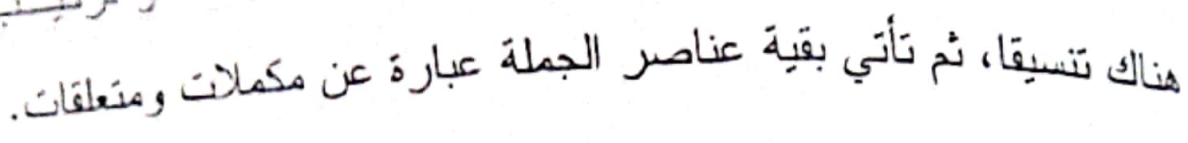
والجملة السابقة تَثلّ فقره كاملة من فقرات النص الو اردة فيه ا-ب- ذكرت في موضع سابق أن نص الخبر الصحفي باتي فسي شــكل

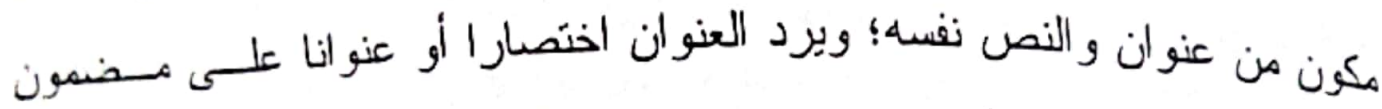
النصل ونو عه، وأضيف أن العنوان دائما برد في صورة جمل اسمية مكونه من مسنذ ومسند إليه، بينما برد النص نفسه غالبا مؤلفا من جمل فعلية تعد جملا أساسبة تنثل

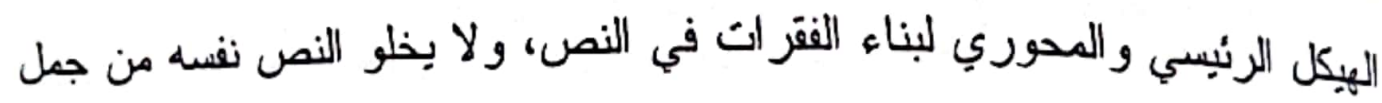
السعية ترد في شُكل جمل اسمية تدخل عليها الأدوات (كان وأخو اتها أو إن و أخواتها)

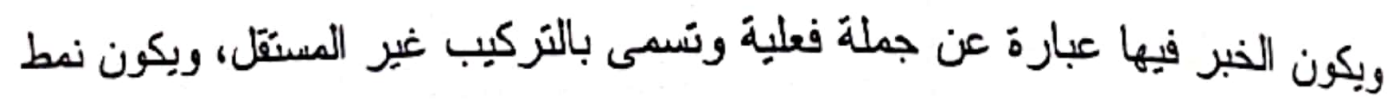
الجملة الاسمية هكذا:

كان وأخو اتها أو إن وأخوتها + اسمها + الخبر (جملة فعلية) لنتامل النص التالي: وزير الصحة في مدرسة الذديوي إسماعيل

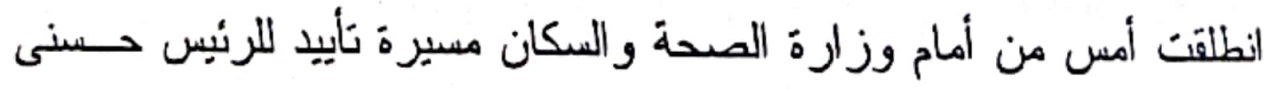

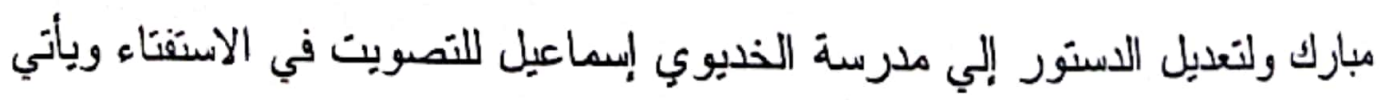

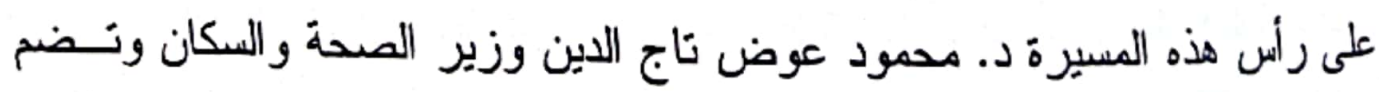
آلآفا من العاملين في المجال الصدي. 


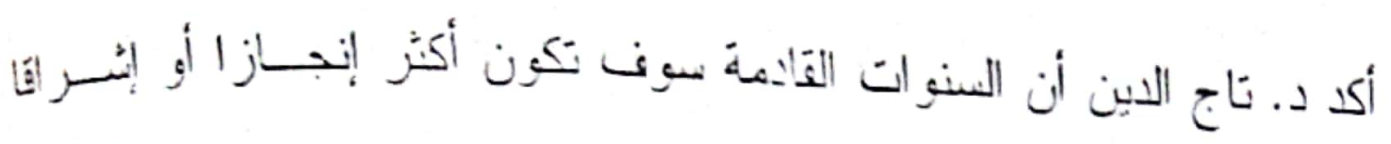

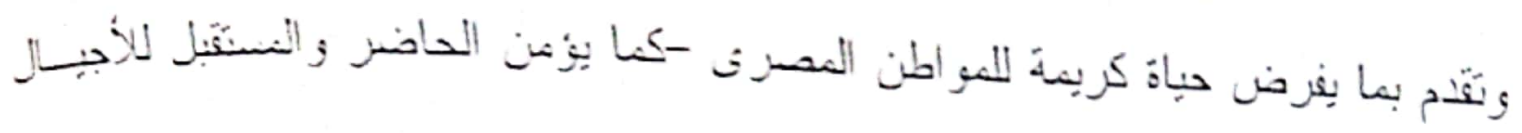

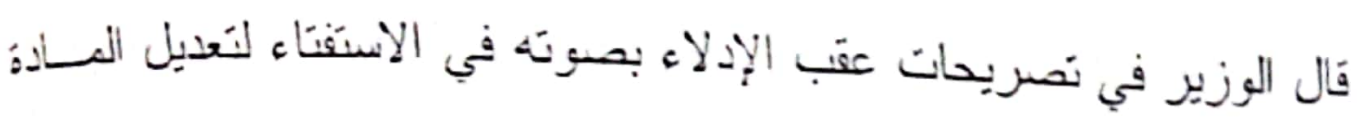

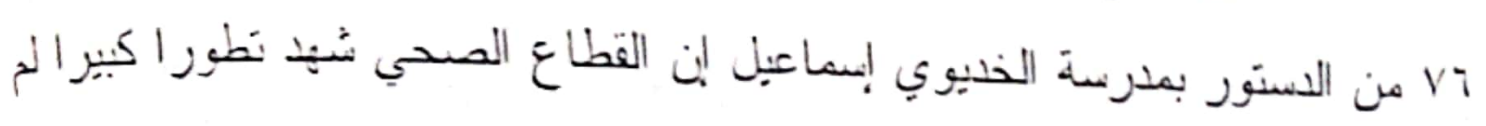

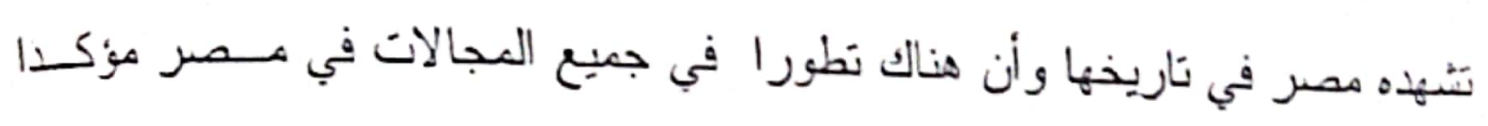
أهمية مفهوم المشاركة للمو اطن المصري.

وأضات وزير الصحة أن التعديل هو نقطة حيوية وهامة في تاريخ مسصر

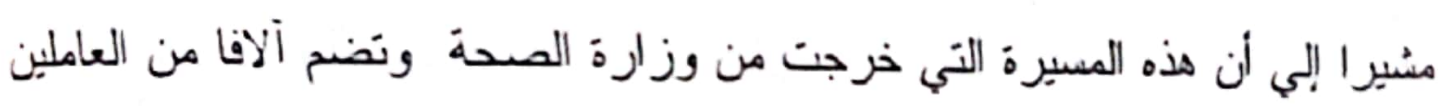

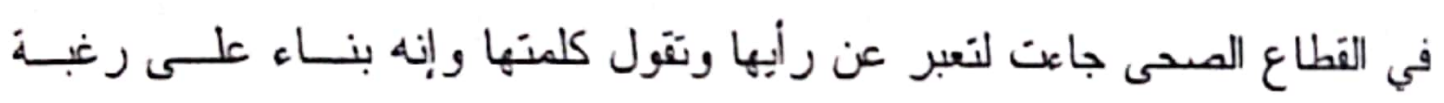
المو اطنين اليوم سوف يقبل الرنيس مبارك ترشيح نفسه لفتر ة قادمة. و أكد ان المواطن المصرى جاء ليضع علامة ممبزة لتاريخ مصر الـسباسي

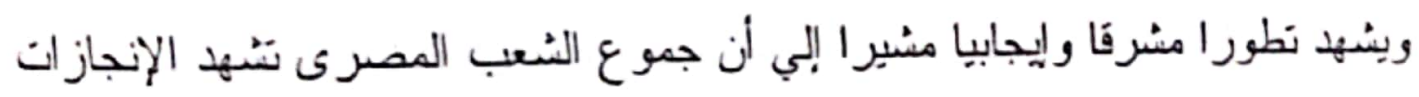

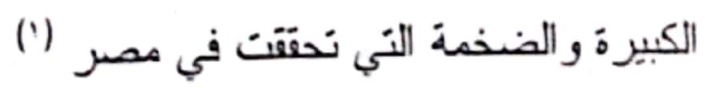

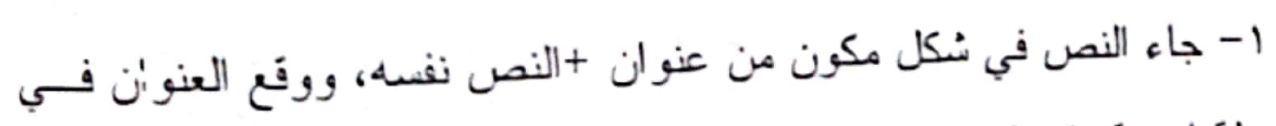

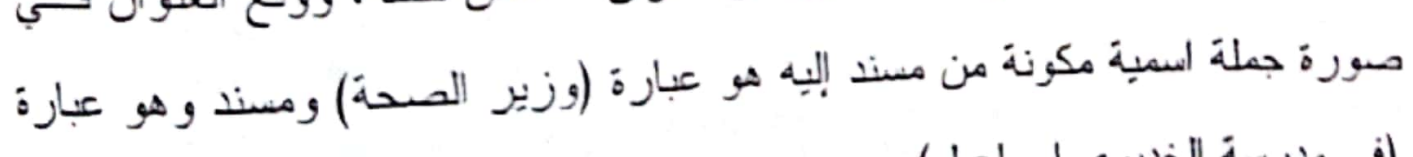

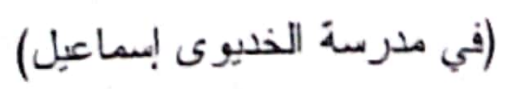

ب- بدا النص مؤلفا من خمس فتر ات؛ كل فقزة اببتَأت بجملة فعلية أساســية

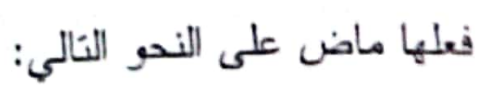




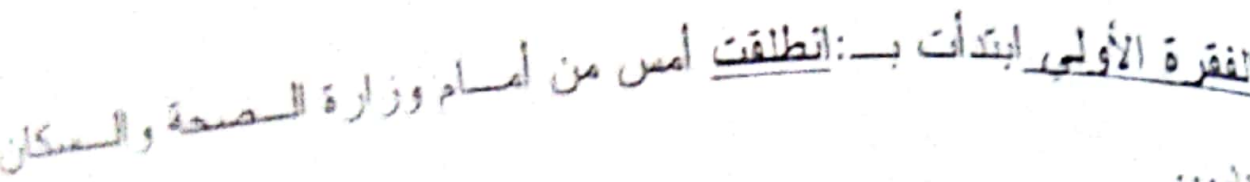

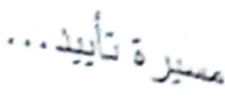

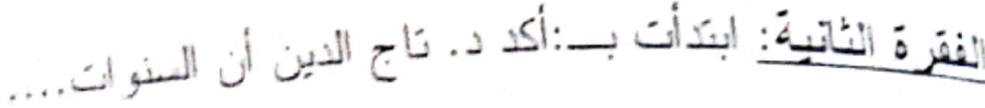

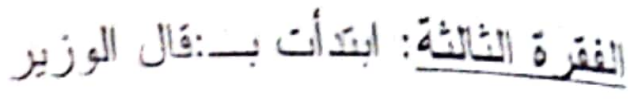

الفقزة الزرابعة: ابنَأت بــ: و أضاف وزبر الصدة

الفنرة الخامسة: ابنتأت بــ:و أكد أن المواطن المصرى

r- جايت غالبية الجمل الاسمبة في النص نفسه مكونة من إنَ أو أنً +1

خبر هما جملية فعلية ويسى بالتركيب غبر المسنقل:

فن أميثة إنَ: إن القطاع الصحي شهدا نطورا كبير 1

- ومن أمتلة أن:: -مشيرا إلي أن هذه المسبرة...جايت

- و وأكت أن المو اطن المصرى جاء ليضع

- منشيرا إلي أن جمو ع الشُبب المصري تشّهِ..

1- ج: ترنبط هذه الخاصية بسابقتها؛ فهن خلال ملاحظتي للجمل الفعلية التـي

بنأف منها نص الخبر الصحفي وجلت أن هناك أفعالا محورية لها تأثير كبير فـي تلاك الجمل، ومن ثُ في بناء نص الخبر الصحفي بصفة عامة. ويمكن تقسيح هذه الأفعال إلي قسمين:

التسبر الأول: أفعال تبذو نسبة ترددها عالية بحيث لا يكاد بخلو منهــا نــص للخبـر الصحفي. 


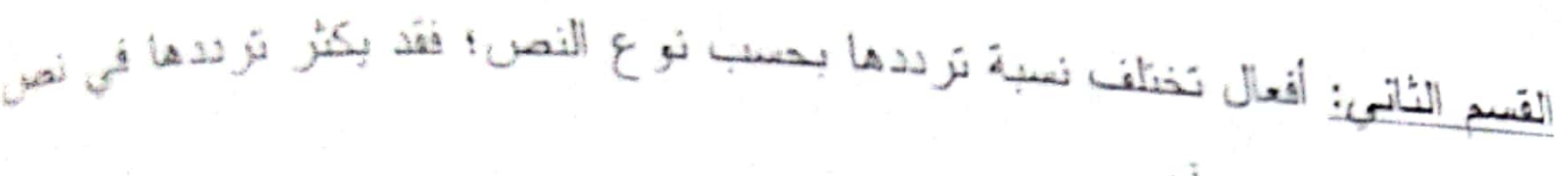
وبئل في نصن أخز

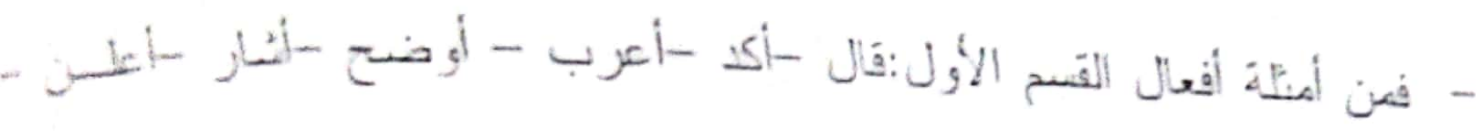

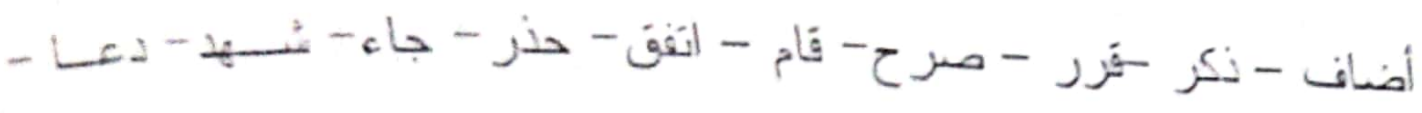

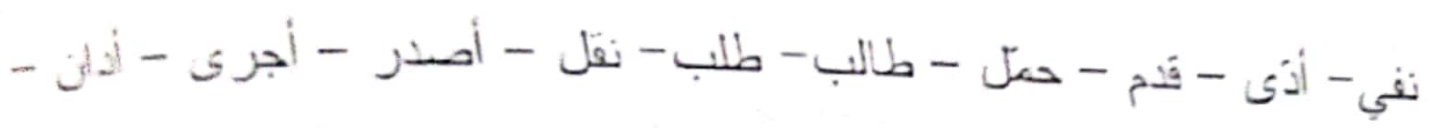

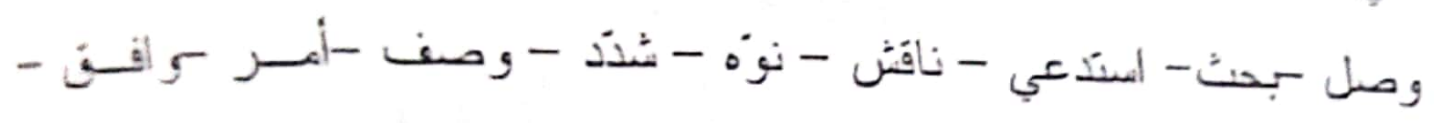

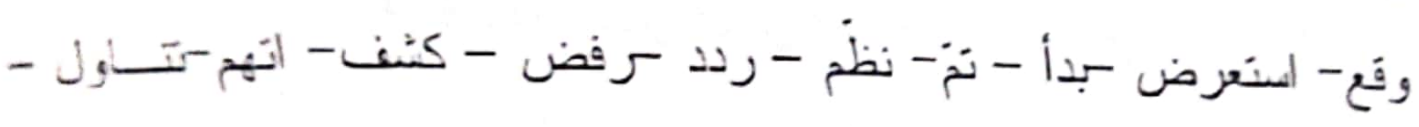

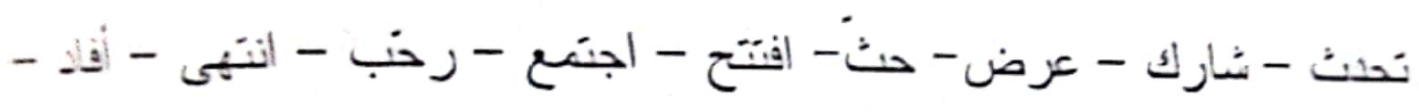

أصنز - (20)

والملاحظ على أفعال القسم العابق أن غالبينها إما أفعال دالة على الكلام وإبــا. أفعال دالة على الحركة

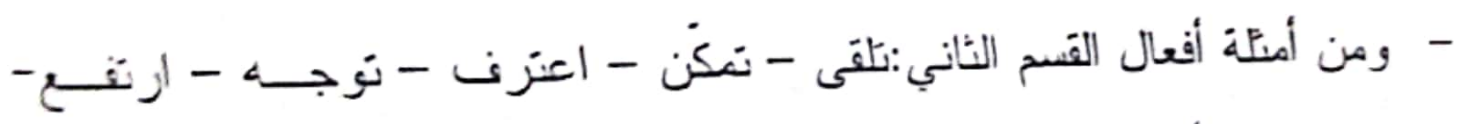

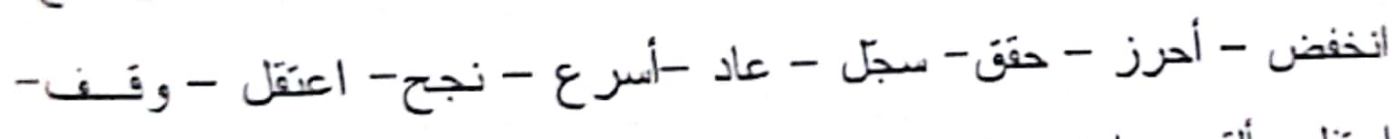

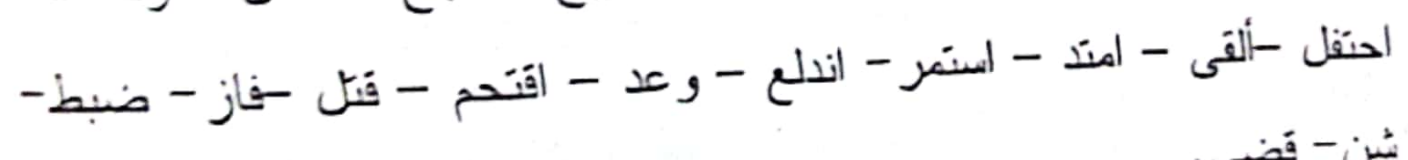
شن - فضى.

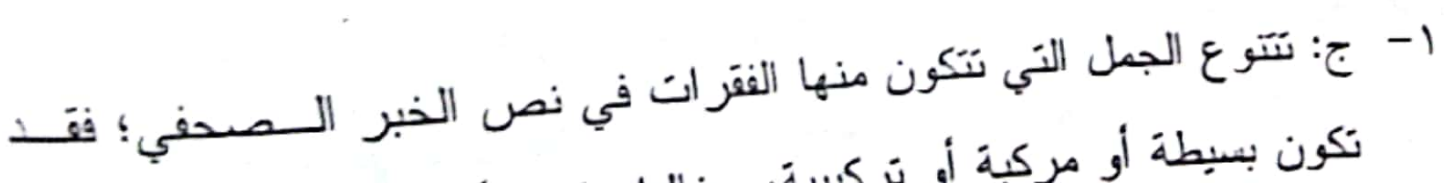

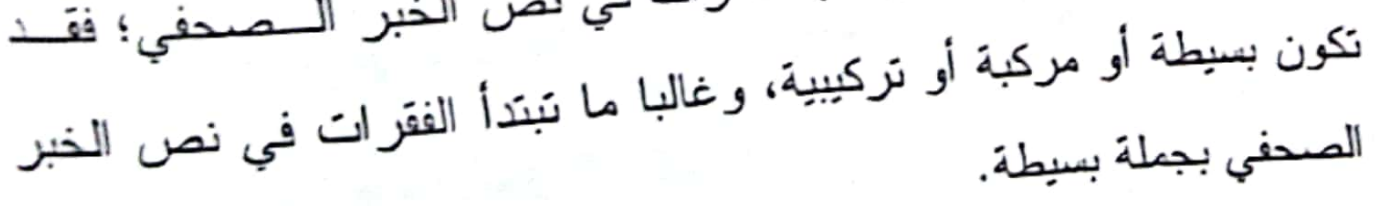

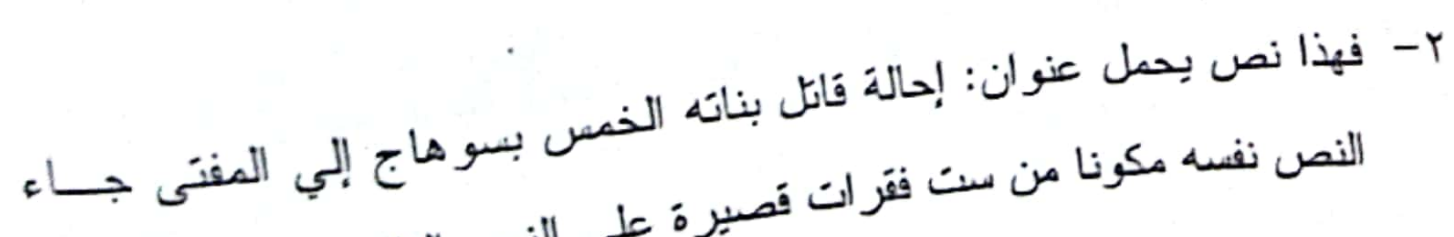

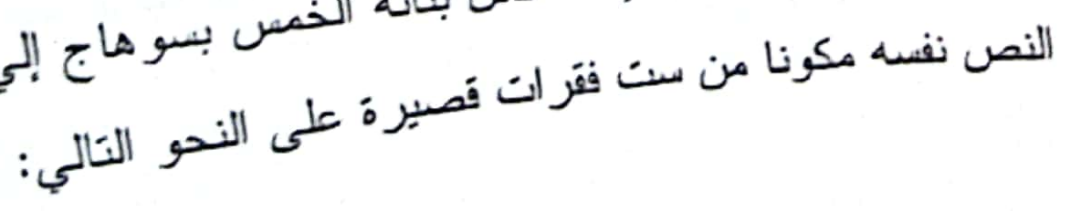




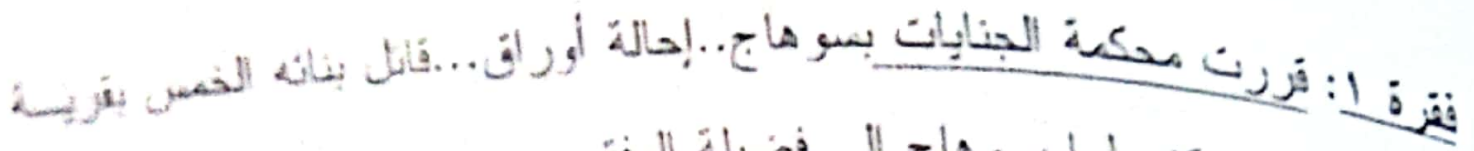

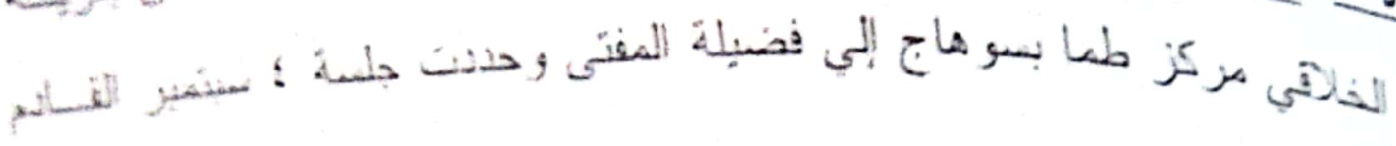

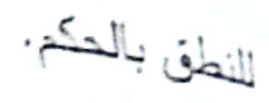

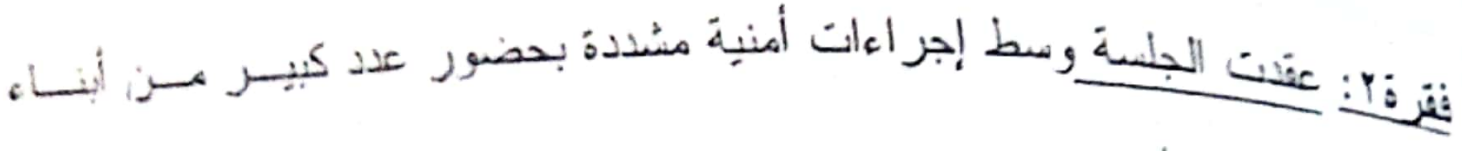

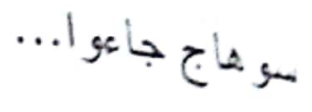

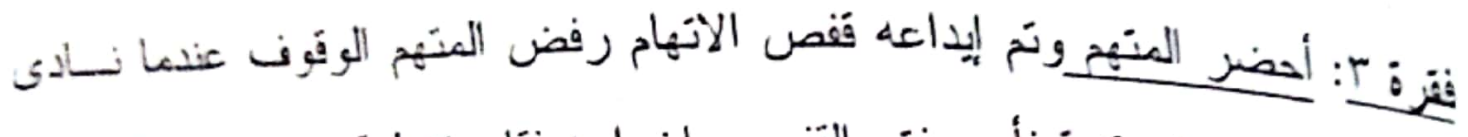
عليه رئيس المحكة فأمر بفتح القفص و إخر اجه فقام بتنطبة وجهه بكوفية)....

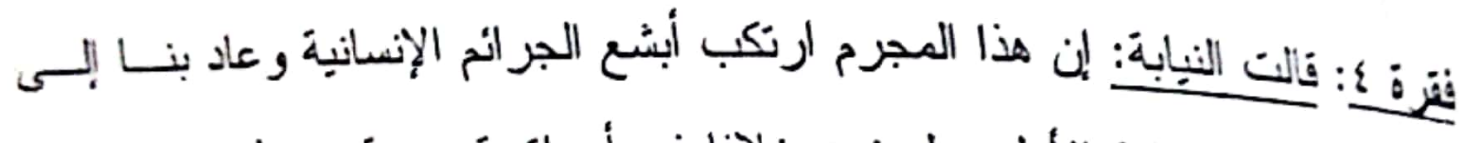

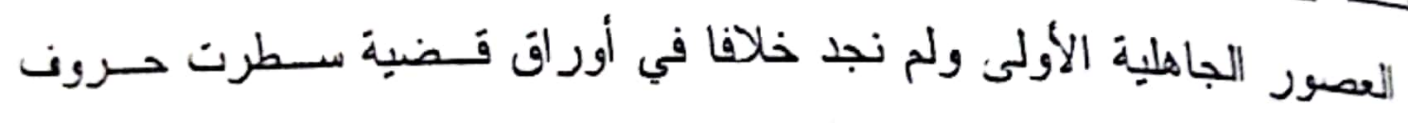

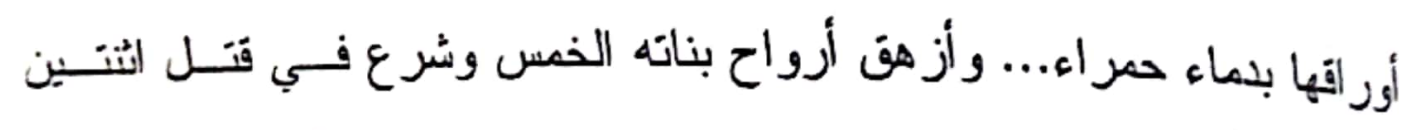

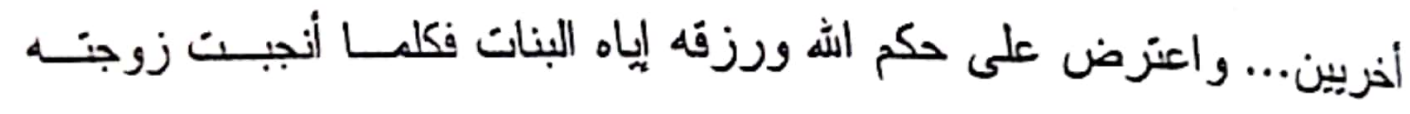
عطبات على بنتا راح يلومها ويؤنبها ويلقى عليها أبشع الألفاظ... فنزة 0: أضان أن المنهر لضيقه بانجاب البنات نزع عنهن صفة الأنوثة فقام بقص

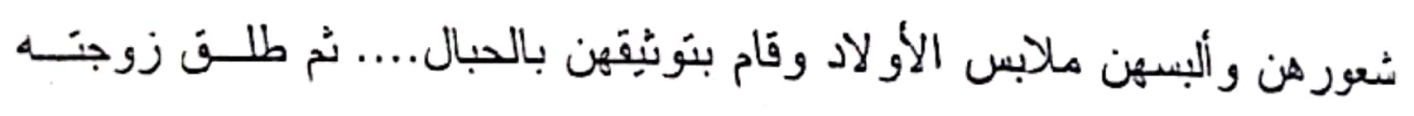

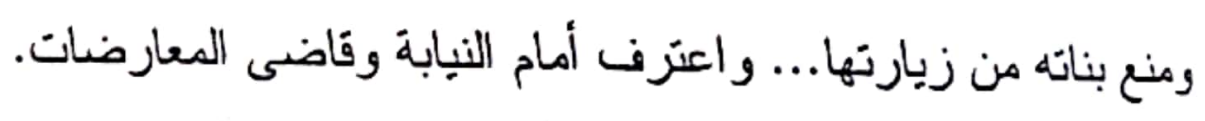

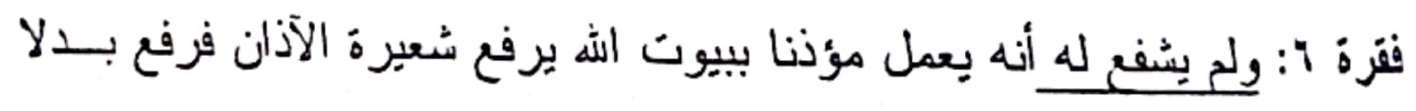
منها شعيرة الشيطان....

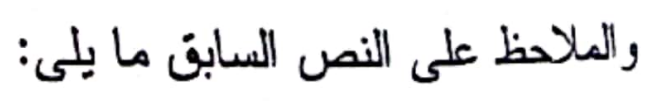
1- ابتدأت فقر ات النص بجمل بسيطة فعلية هى: هُرت محكمة.....، عقدت الجلسة........ أحضر المتهم................ 


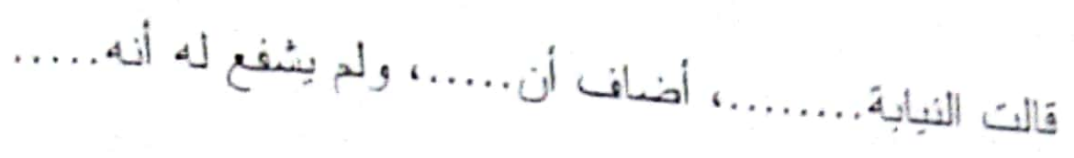

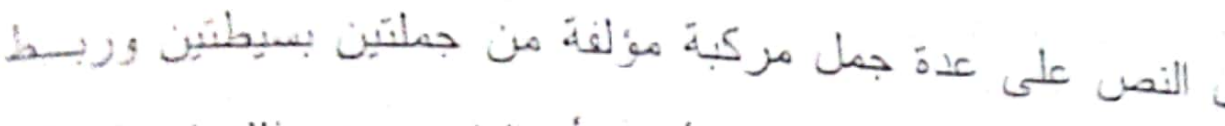

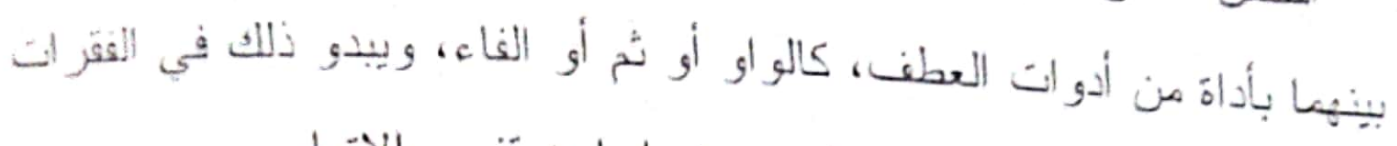

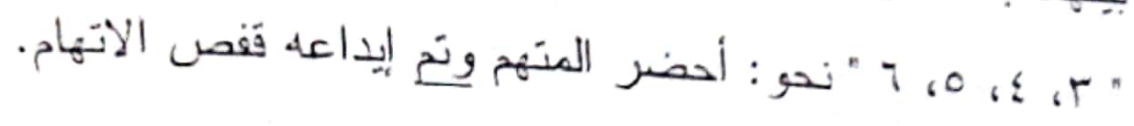

- - إن هذا المجزم ارتكب أبشَع الجرائم الإنسانية و عاد بنا إلى العصبر الجاهلية الأولى.

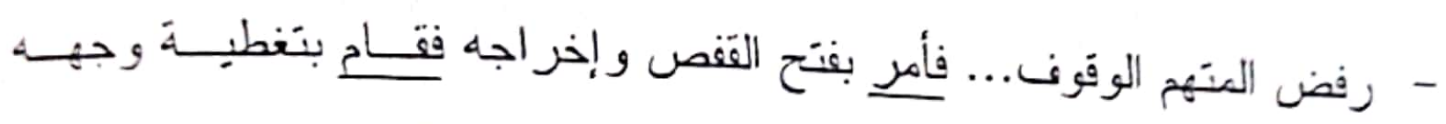
ونز ع عنهن صفة الأنوثة فقام بقص شعور هن... ثم طلق زوجنه.... - - ويبذو أن كثرة استخدام أدوات العطف (الواو - ثم - الفاء) يعود إلى طبيعة نص الخبر الصحفى من أنه نص سردى يهدف إلى نقل الأحداث و المعلومات

$$
\text { و عرضها في صورة متتابعة. }
$$

r- اشتنطل النص على جملة تركيبية مكونة من جملة بسيطة وتركيــب غيـر

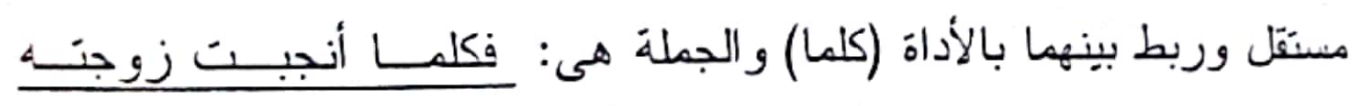
عطيات على بنتا راح يلومها ويؤنبها.

ا-ص: تتعدد الأنماط الخاصة بالجملة البسيطة و الجملة المركبة و الجملة التركيبية في

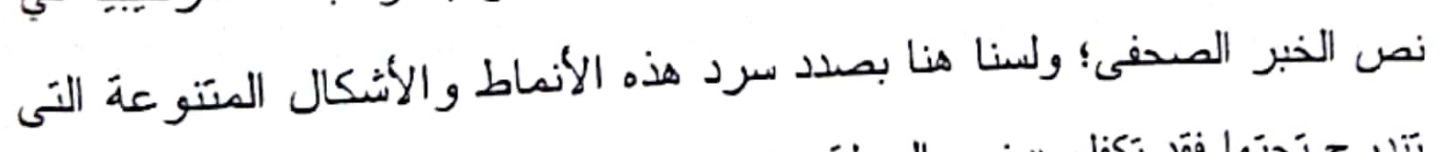

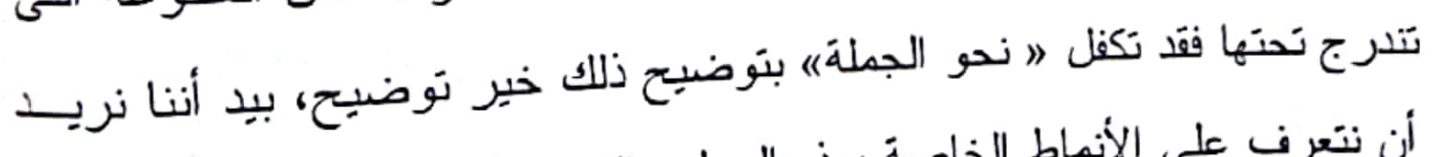

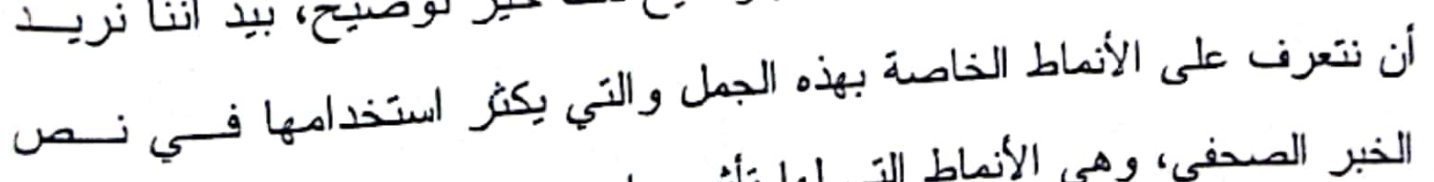

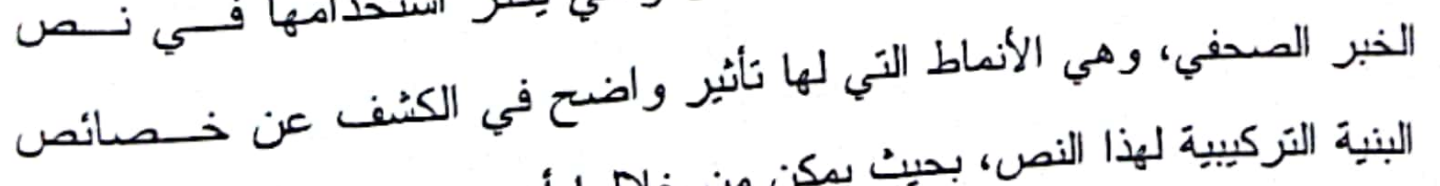

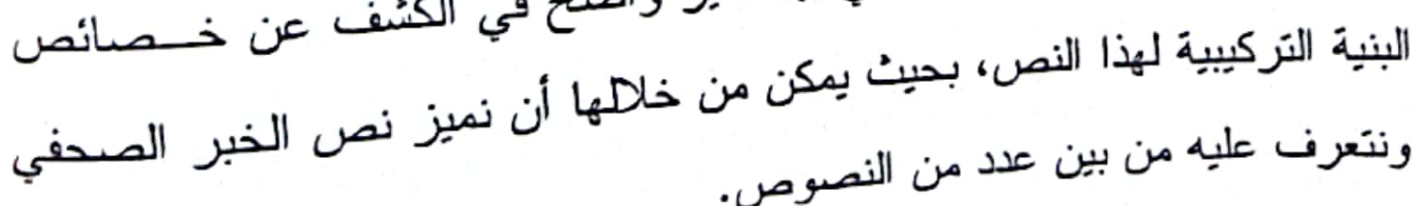
ونتعرف عليه من بين عدد من النصوص. 


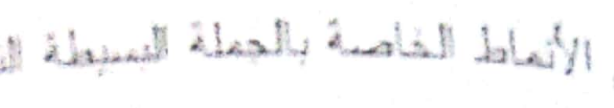

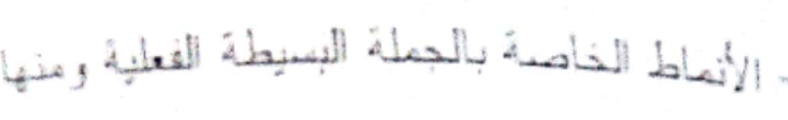

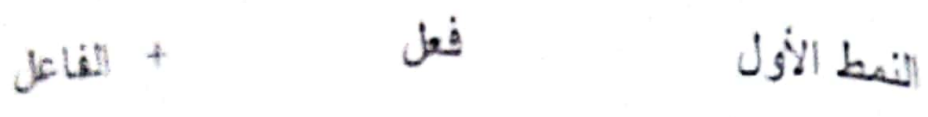

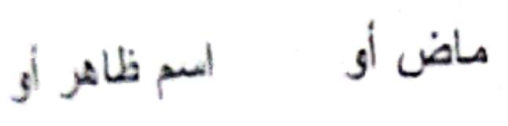

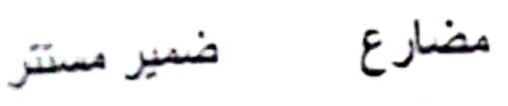

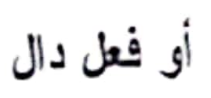

$$
\begin{aligned}
& \text { على المثاركة } \\
& \text { ومن أمثية هiا النمط }
\end{aligned}
$$

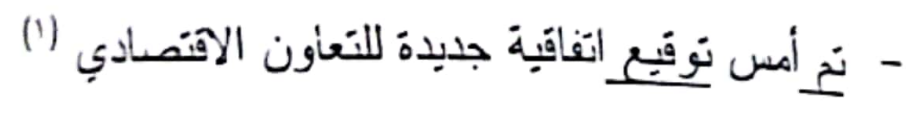

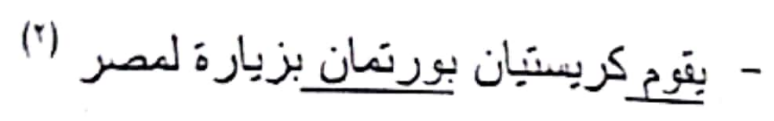

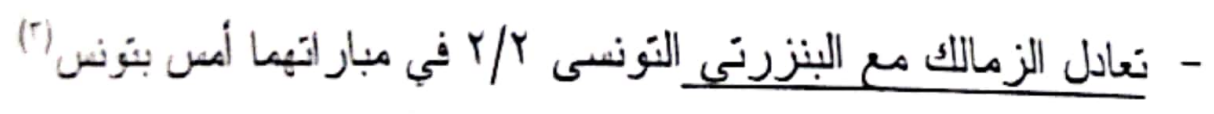

$$
\begin{aligned}
& \text { - وتزيد أمر اض الحساسية مع تقلب الجو .. منها الرمد الربيعي الأي بحسث في }
\end{aligned}
$$

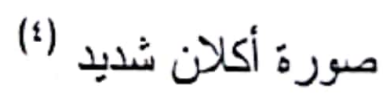

$$
\begin{aligned}
& \text { النمط الثاني: فعل + نائب فاعل ومن أمنتـ: }
\end{aligned}
$$

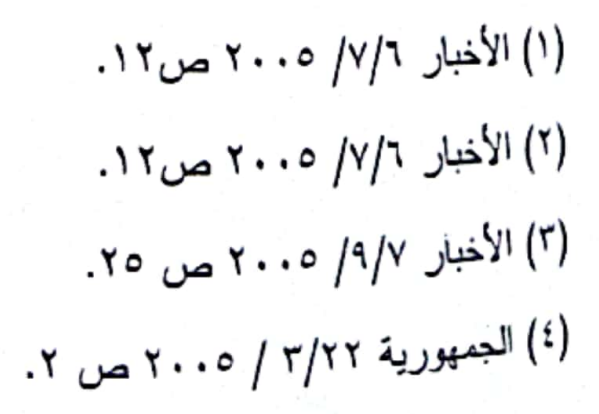




$$
\text { مضاض أو اسم ظاهر }
$$

- أجربت بنجاح باهر بوحدة جز احة الوجه و الفكين ..و احدة من أعقد عليـات

(') الوجه

- تَقشُ يوم السبت القادم بكلية الحقوق رسالة الدكتور اه (r)

- - النمط الثالث:

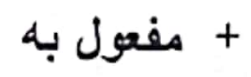

اسم ظاهر أو تركيب

غير مستقل مكون من: أن و اسمها وخبرها ويرنبط بالنمط السابق صورة أخرى مكونة من:

$$
\text { فاعل + + + + + }
$$$$
\text { + فاعل }
$$

فعل

جملة مكونة من إنت

$$
\text { اسم ظاهر }
$$

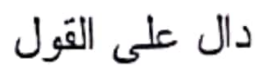

و اسمها وخبر ها

$$
\text { أو ضمير مستتر }
$$

و النمط الثالث السابق من الأنماط الشائعة في نص الخبر الصحفي، و السبب في شيوع هذا النمط بِعود إلي أن غالبية أفعاله من الأفعال الدالة على الكــلام التــي

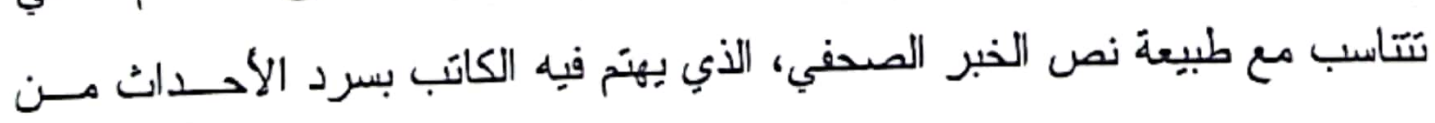

$$
\begin{aligned}
& \text { (1) الأخبار /o/o o . . ص صll. }
\end{aligned}
$$

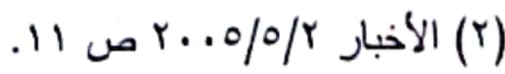




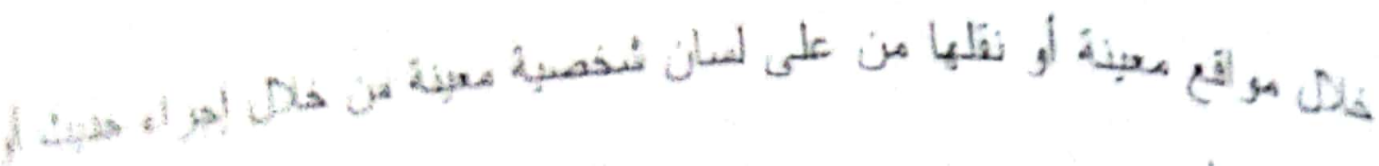

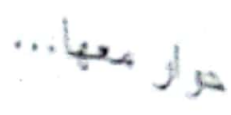

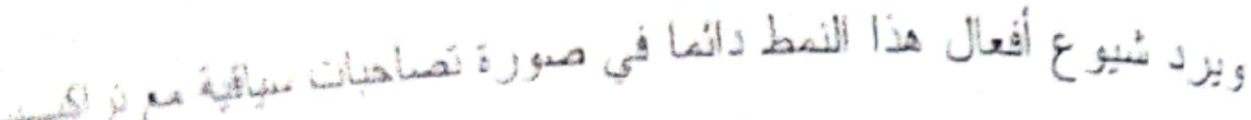

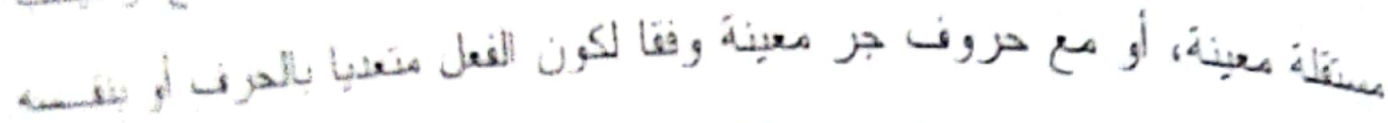

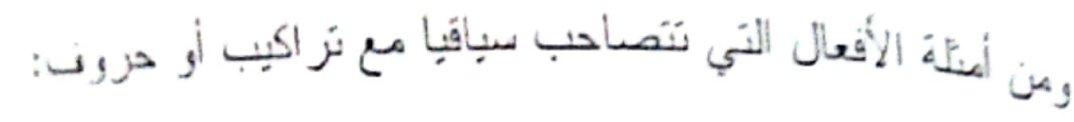
أك + أن - أوضح + أن - أضان + أن صر ح+بأن ctis

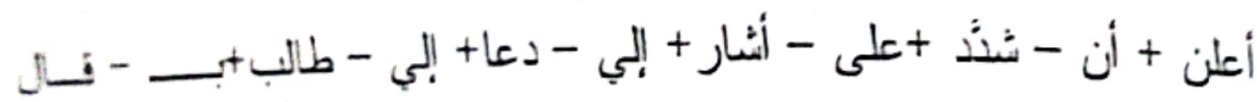

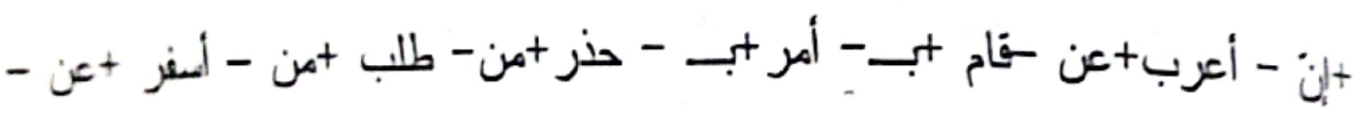

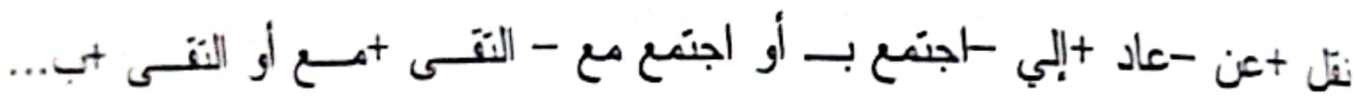

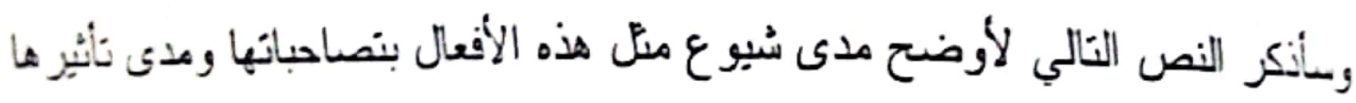

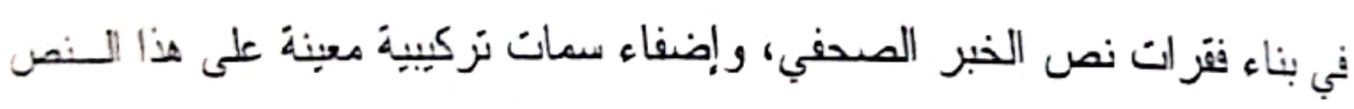

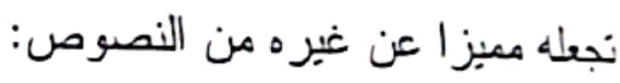

النص بحمل عنو انبوش بكلف إدارته بإجر اء مباحئات جـادة هـع مسصر لوضع أسس اتفاق للتجارة الحرة.

النص نفسه مكون من عشر فقرات بعضها طويل وبعضها فصر على النحو الثالي" (1)

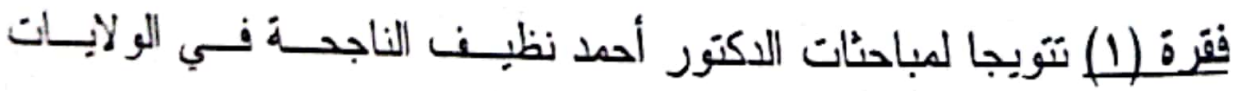

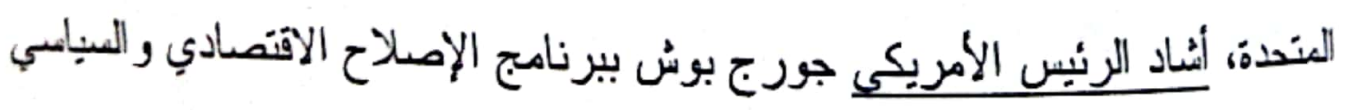
المصرى، وكلف الممثل التجارى بالشروع....

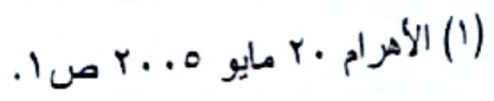




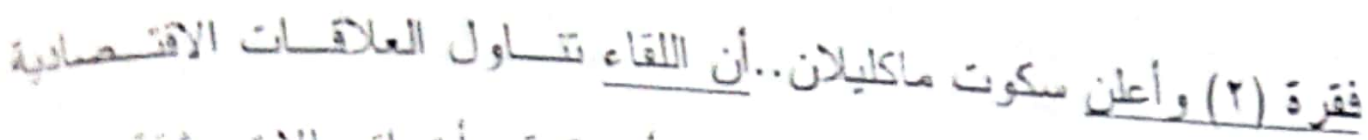

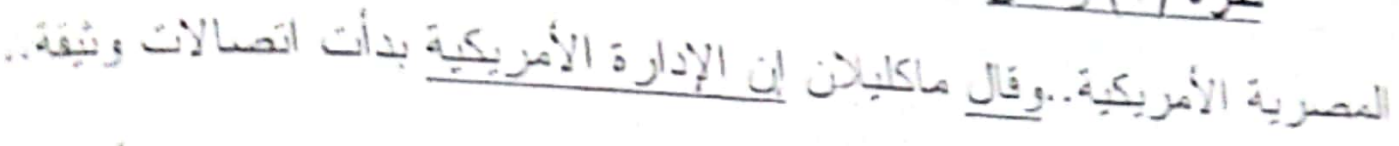

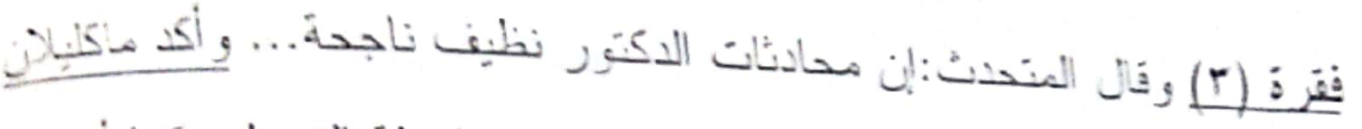

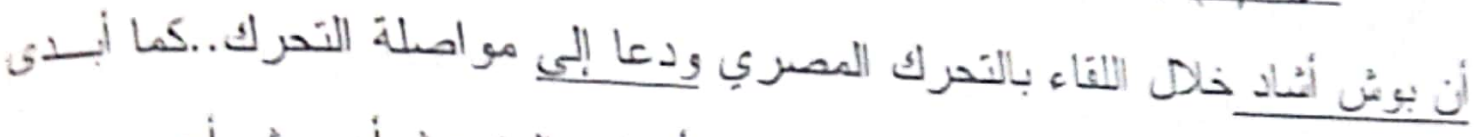

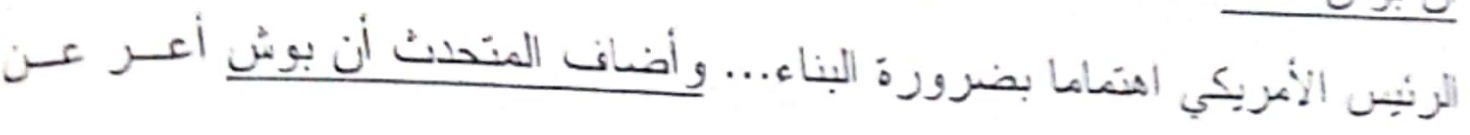
نتميزه للأور القبادي لمصر.

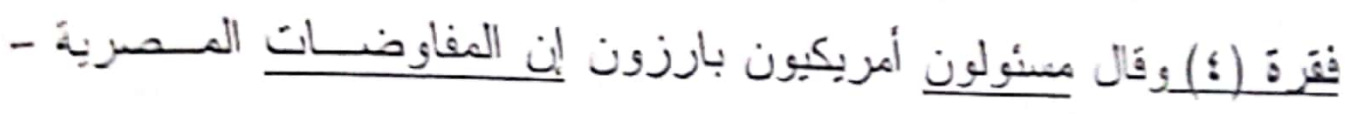

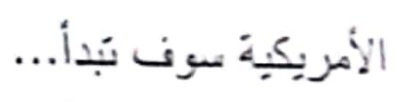

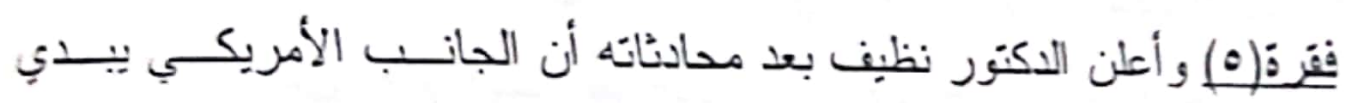

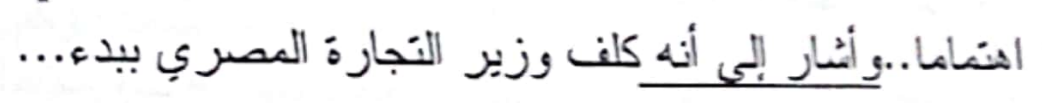

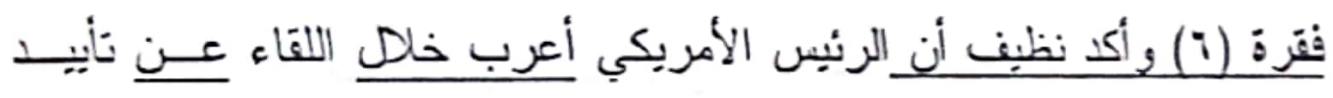

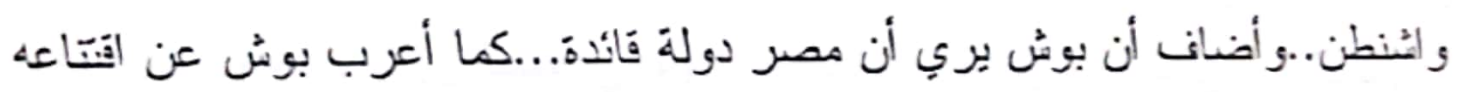

بنقل مصر .

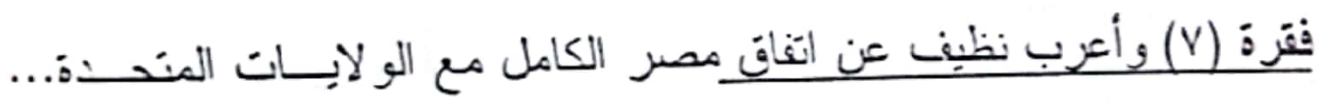

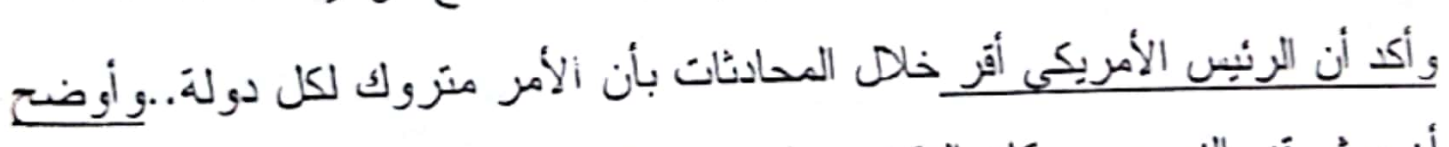

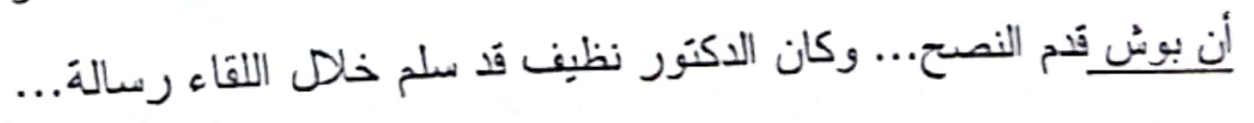

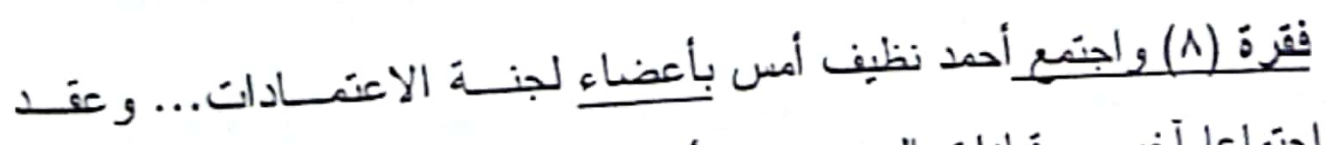

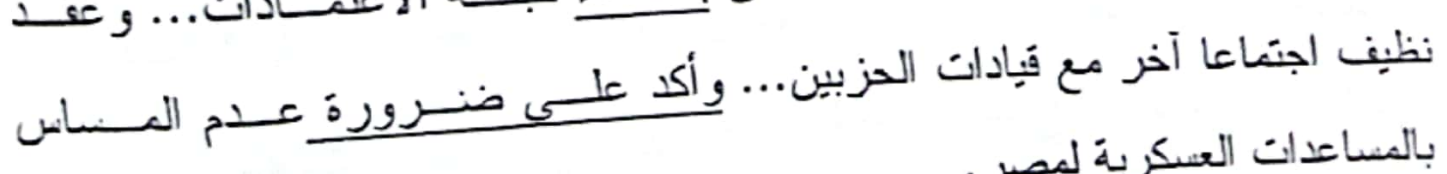
بالمشاعدات العسكرية لمصر. 
فقرة(9) وقد أئساد أعضاء لجنة الاعنمادات. .بعبادرة الـرئيس مبسارك...

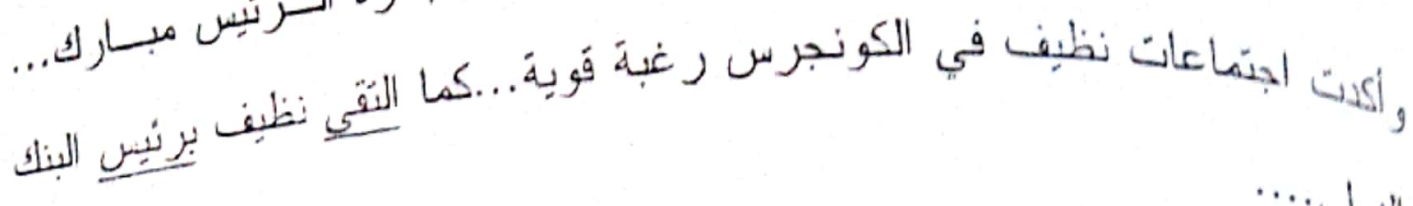
…ㄴ.

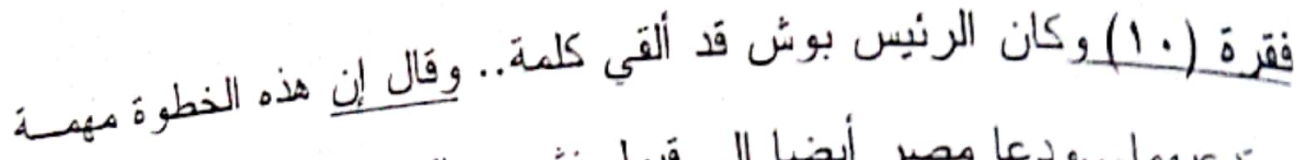
ورعا إلى تدعيها. ...ودعا مصر أيضا إلى قبول نشر مر اقتبين دوليين....

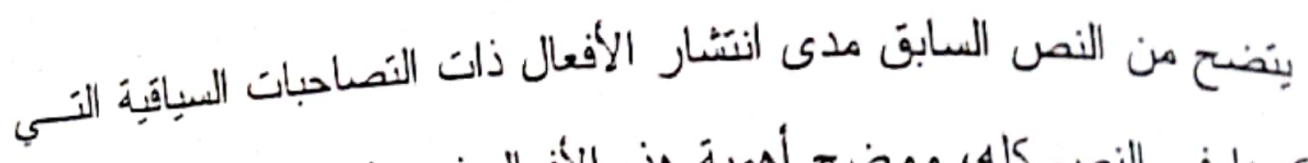
سبق ذكرها في النص كله، ووضنح أهمية هذه الأفعال في بناء جمل النص وفتراته، ونبين أيضا دور ها في إعطاء نص الخبر الصحفي سمة نزكيبية شكلية تمبزه من بين النصوص.

والأفعال التي نقصدها هنا هي التي تم وضع خط تحنها في النص السابق. ووضح إِيضا كثرة استخدام الجمل الفعلية في النص السابق ونــص الخبـر الصحفي عامة؛ وذلك لاهنمام هذا النص بالحدث الذي بعبر عنه في اللغة العربية من

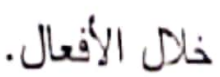

\section{ب- الأماط الخاصة بالجملة البسيطة الاسمية:}

أعرض للأنماط التي يكثر دور انها في النص نفسه دون العنــاوين الخاصــة بالنصوص التي نعرن بغلبة الجملة الاسمية على تر اكيبها

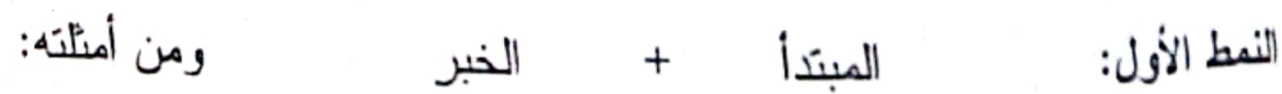

فعل - مل اسم

و للاعبون أنفسهم دخلو الجو اء المبار اة منذ لحظات الأولي للمعكر الأملى فاز بستة أهدان نظيفة في القاهرة 
الزمالك استفاد من مبار اتي دور الــr (1)

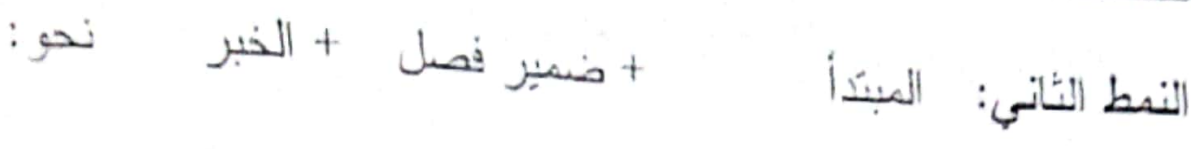
السم

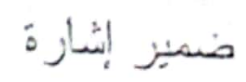

هذا هو سادس فوز على النو الي لريبال مدريد (')

و النعطان السابقان بكثر دور أنهما في نص الخبر الفني ونص الخبر الرياضى.

النمط الثّالث: كان + اسمها خبرها

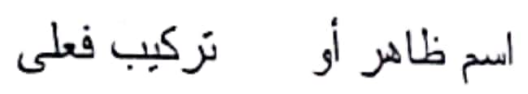

ضمير مستزر مقترن بقد نحو:

وكان د. فتحى سرور قد ألقى بيانا حول إنجازات المجلس (־)

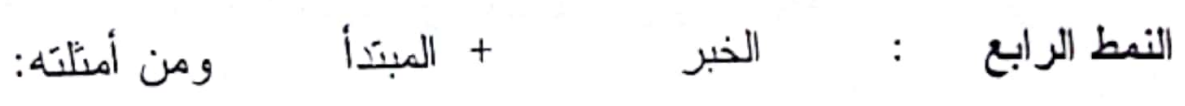

$$
\text { جارو ومجرور أن +الفعل }
$$

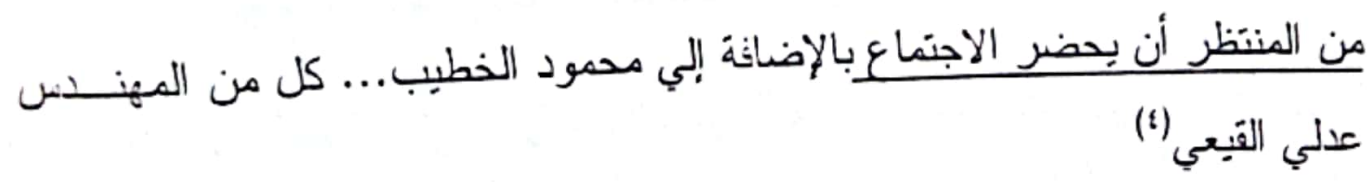

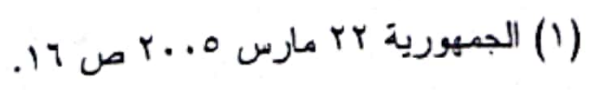

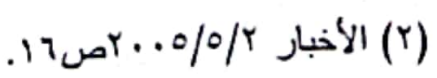

$$
\begin{aligned}
& \text { (r) الأخبار (ك/r) } \\
& \text { (ई) الجمهورية آيوليو ه... }
\end{aligned}
$$




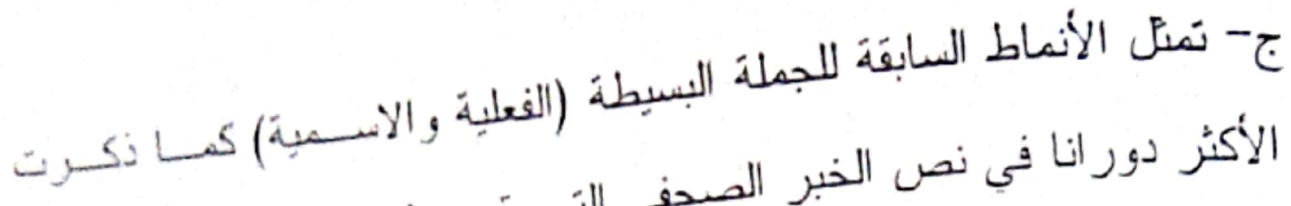

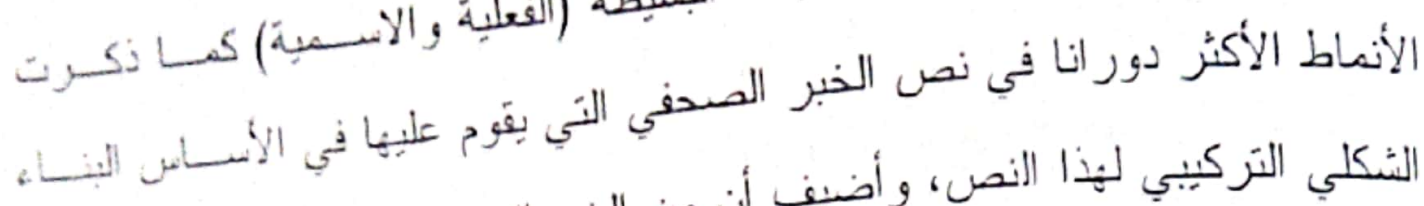

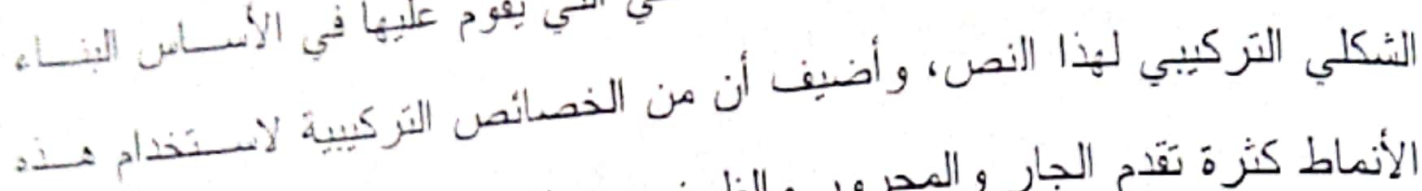

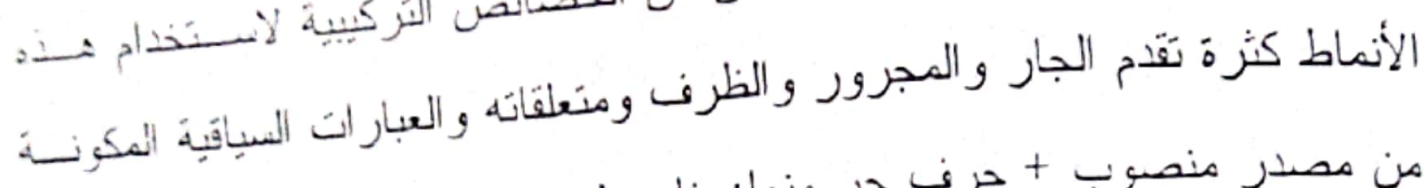

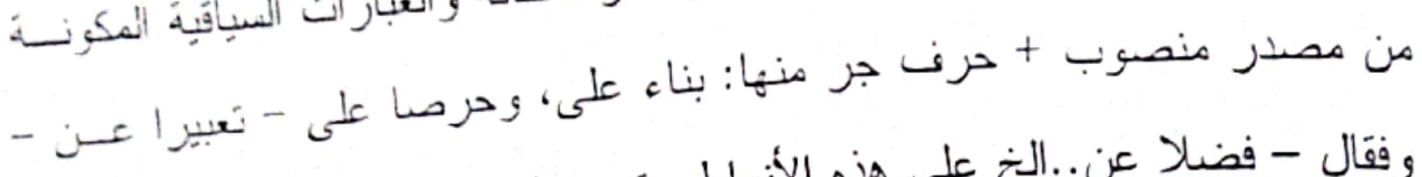

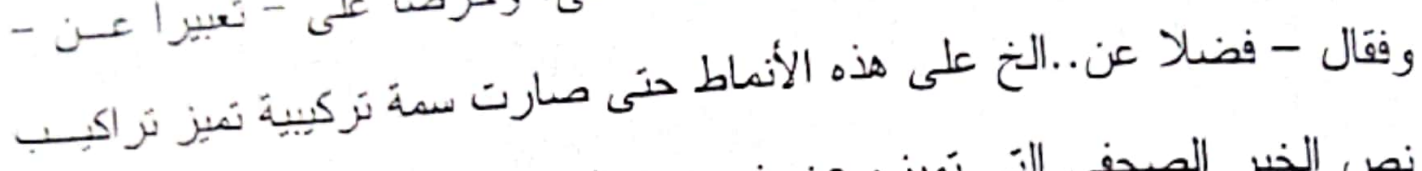

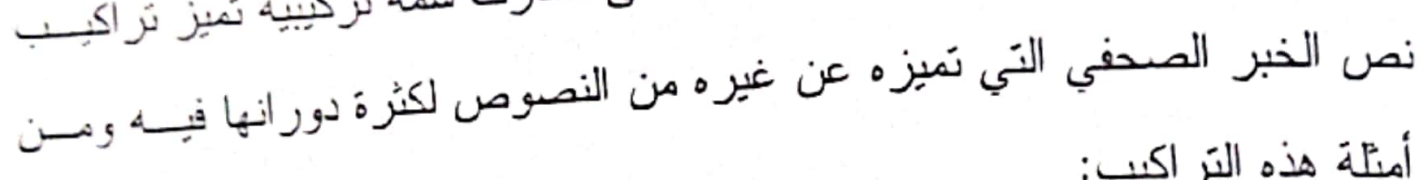
أمئة هذه التر اكيب:

- في أكبر مأساة إنسانية بالعراق منذ بداية الغزو الأمريكي لقي ندسب ألـــ

(') (1)

- حول الاقتر اح الخاص بتوسيع عضوية مجلـس الأمسن ذكـرت صــيفة نيويورك تايمز أن عنان......

- ونظر للنجاح الذى تحقق في هذا الصدد، وطمعا في اسنَر اره تقرر النَّسع في تلك المكانب بجميع المحافظات(؟).

- - حسب تَرير أصدرته الجامعة فإن المنتج الأسمنتي الجديد تم استخدامه فــي إجراء أكثر من أربعين عملية جر احية (؛).

$$
\begin{aligned}
& \text { (1) الاخبار سبتمبر . . . P ص ا. }
\end{aligned}
$$

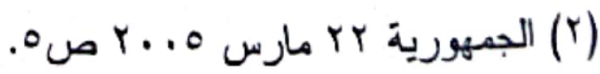

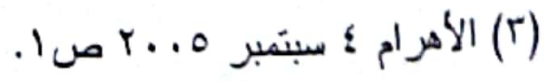

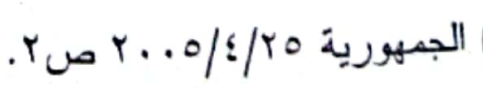




\section{r- ومن الأنماط الخاصة بالجملة المركبة:}

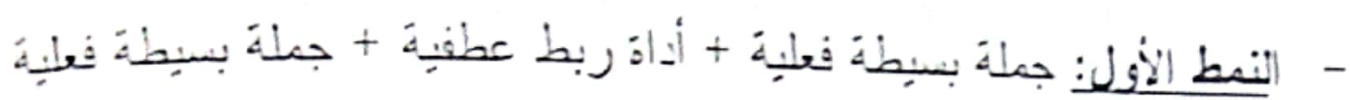

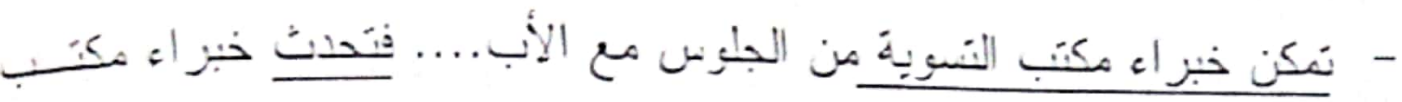

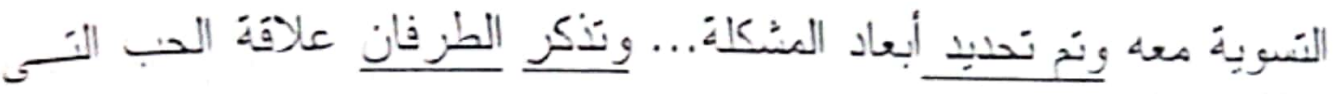

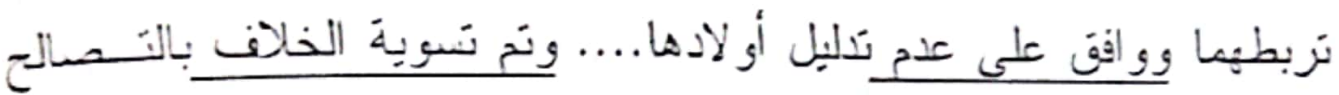

ليعود الهيدو والاسنترار للأسزة (').

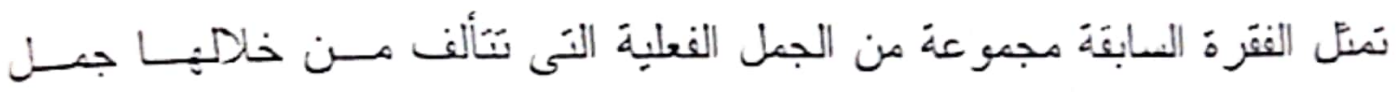
مركبة، وقد ربطت بين هذه الجمل بأدو ات العطف (الو او ) و (الفاء).

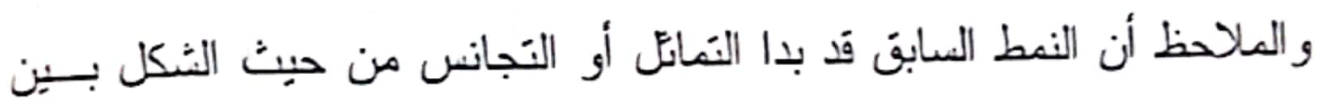
جمله، فعطفت الجملة الفعلية عـلى نظيرتها الفعلية، و هذا النمط بكثر دورانه في نص الخبر الصحفي بصورنه هذه.

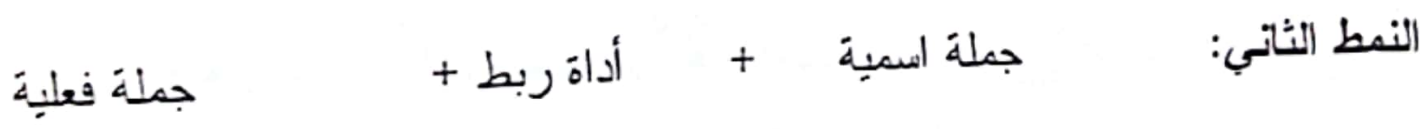

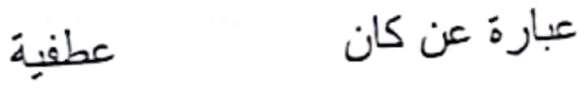

$$
\begin{aligned}
& \text { و اسمها وخبرها }
\end{aligned}
$$

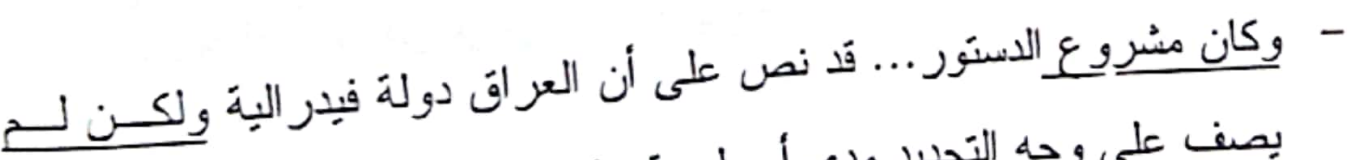

بصف على وجه التحديد مدى أو طبيعة هذه الفيدر الئة(").

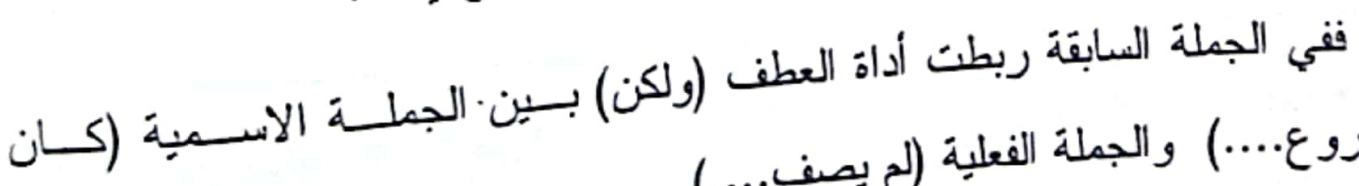

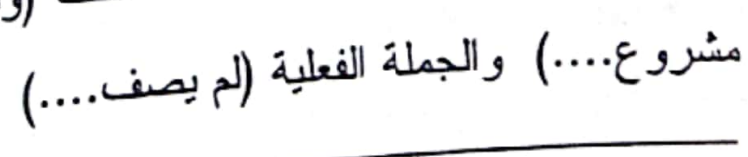

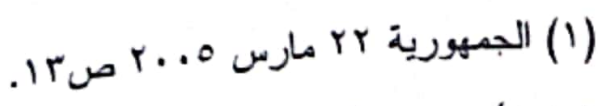

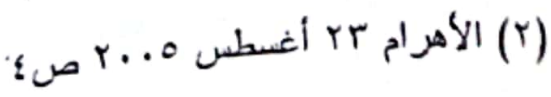




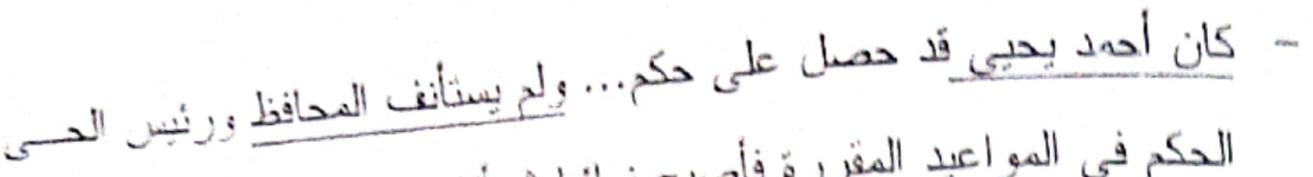

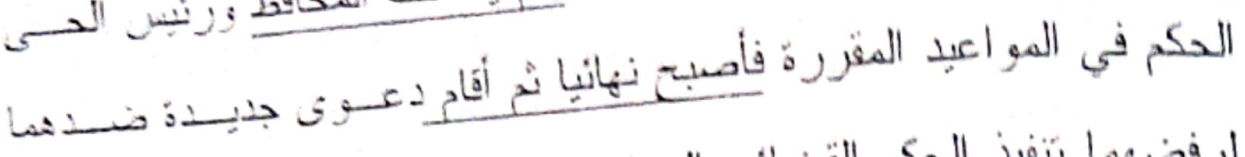

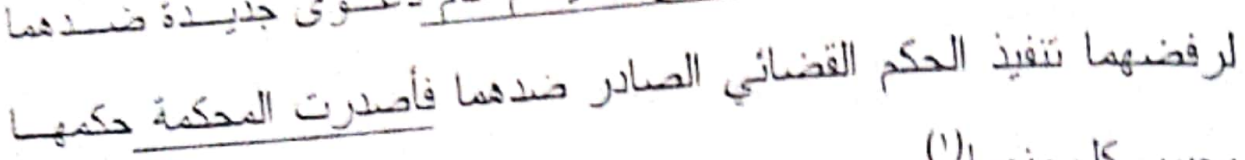

$$
\text { بحبس كل منهما' (1) }
$$

في الجمل السابقة ربطت (الواو) بين الجملة الاسمبة (كان أحسـد)... و الجملــة

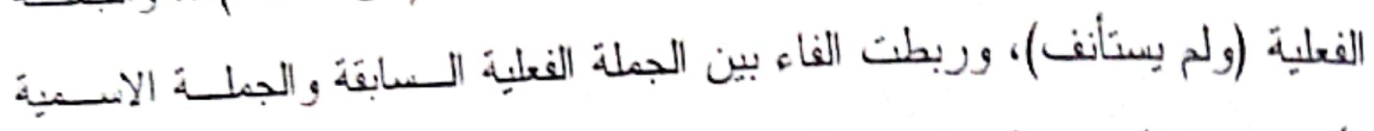

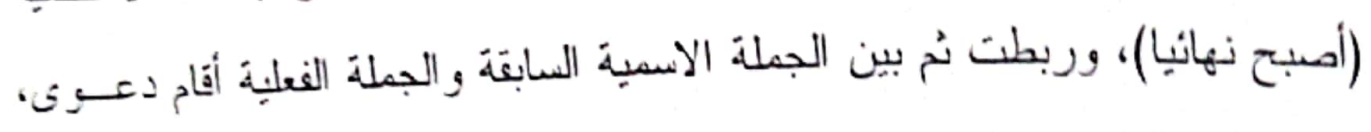
وقّد ربطت الفاء بين الجملة الفعلية السابقة و الجملة الفعلية (أصدرت المحكة). و النمط السابق أبضا الذى يربط فيه بين جملة اسمية مكرنة من كـان وانسـبـا وخبرها، وبين جملة فعلية أخرى من الأماط التى يكثر دور انها في نـص الخبـر الصحفي، وقد اتضح فيه عدم وجود تمائل في النُكل بين أطران الجملة المركبة.

$$
\text { النمط الثالث: جملة اسمية }
$$

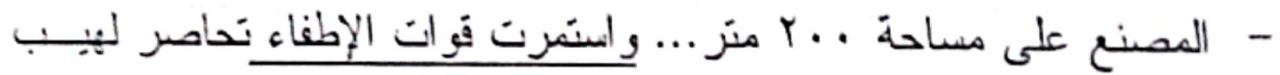

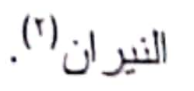

$$
\text { جملة فعلية + أداة ربط + جملة اسمية }
$$

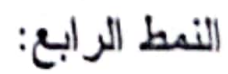

عطفية

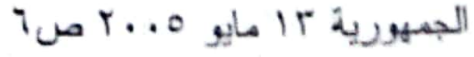

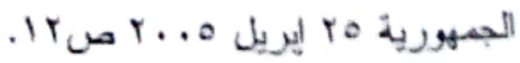




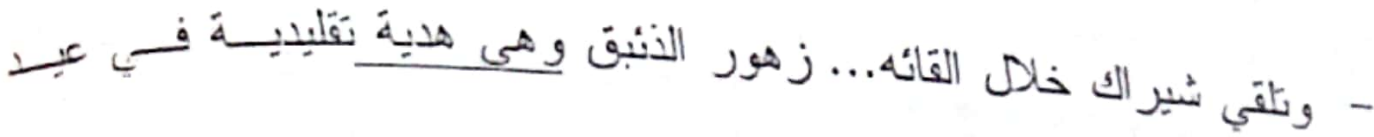

(') (1) (1)

و النمطلن المابقان أيضا كثير الأوران في نص الخبر الصحفي ووضح فيهــا عدم التماثل أو التجانس بين أطر اف الجملة المركبة.

ج- ومن أنماط الجملة التركيبية:

تَنتخم الجملة التركيبية في بناء نص الخبر الصحفي، من خلص الأدوات التـى وصى

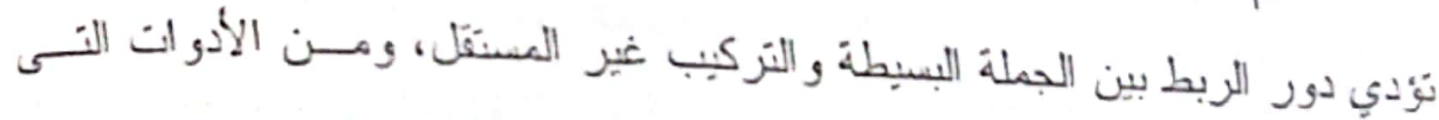
بِتَّن عليها كثير ا في نص الخبر الصحفي للقيام بهذا الدور : بينما، كما، و على الرغم

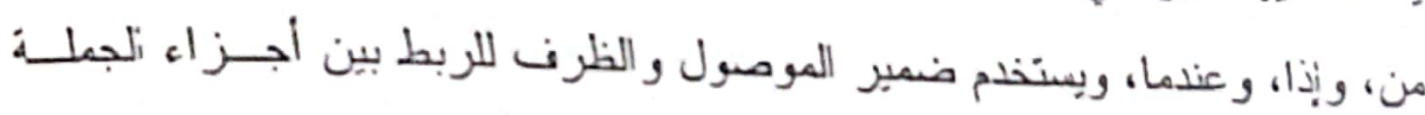

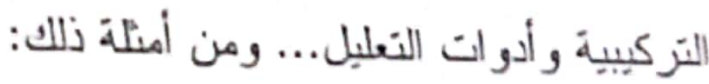

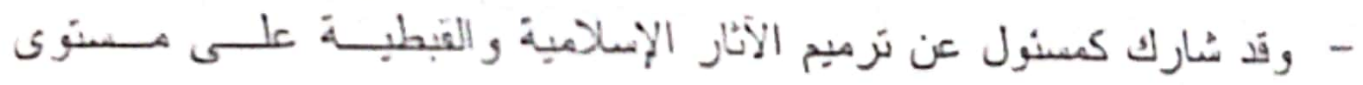

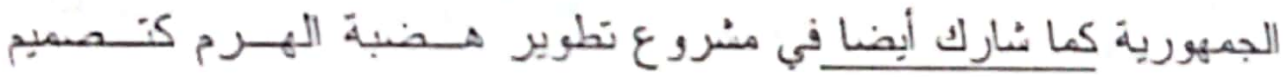

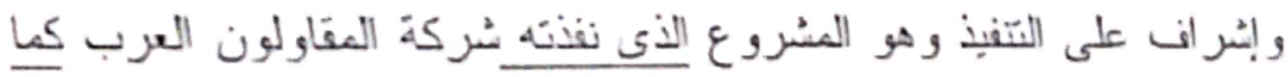
أنه المسئول عن إنشاء، وصيانة المتاحف على منست ى الجمهورية كما شارك

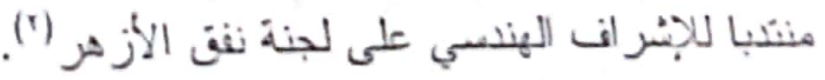
- و إذا فكرت جهة أى جهة رسمية أو أهلية في تنفيذ هذه التجربة في مسصر حلا لمنكلة المُباب... فأنا معنغ لخوض هذه التجر بة معهم مجانا (r).

$$
\begin{aligned}
& \text { (1) الأخبار r مايو r... صמי. }
\end{aligned}
$$

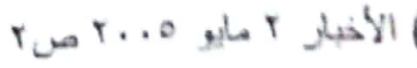

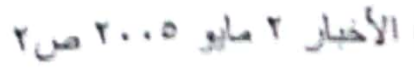


- - على الرغخ من ارتباط اسمه بالتى شبرت الأحمر .. الكورة... الأحسـول.. إلا

أن شهرة خالد الارندى في مجال البنوك كمصرفي منَمبز (')

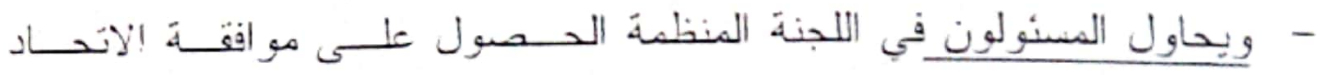

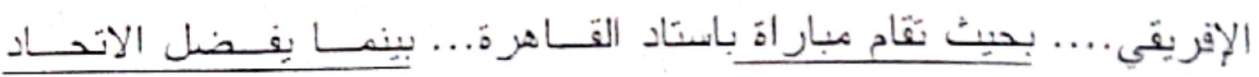

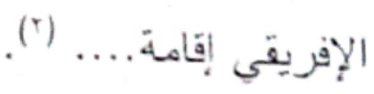

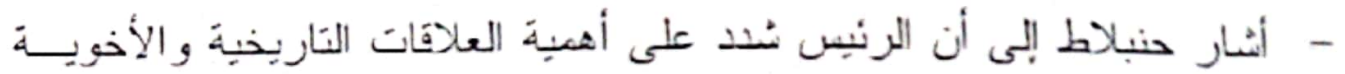

بين لبنان وسوريا... لأنتا لا نريخ أن نعادي سوريا ولكن الأمور لا بمكن أن ولن

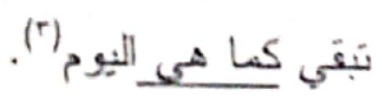

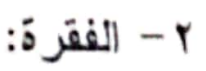

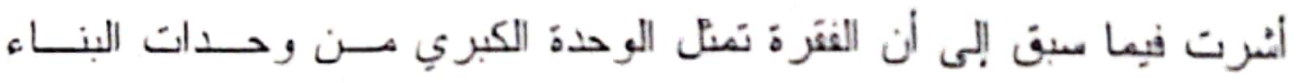

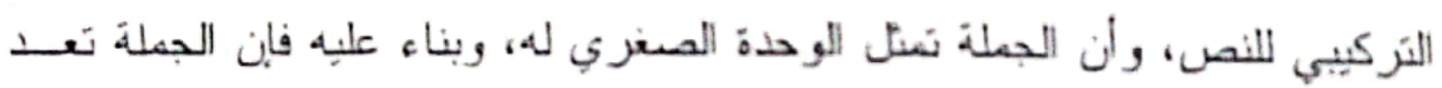

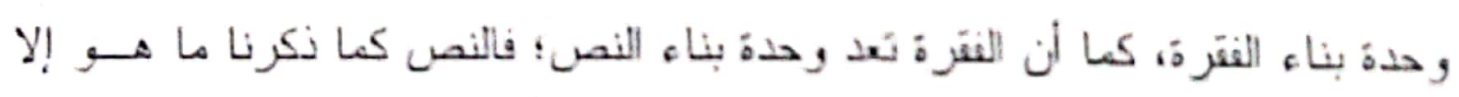

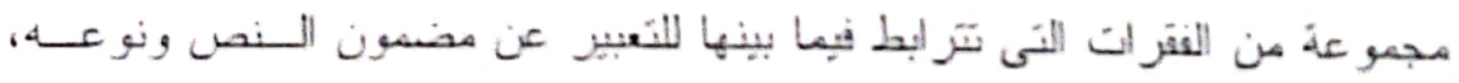
وينّاوت حجم النص منكلبا من حبث طوله وقصر ه بحسب عدد الفتـر ات وحجمهـا

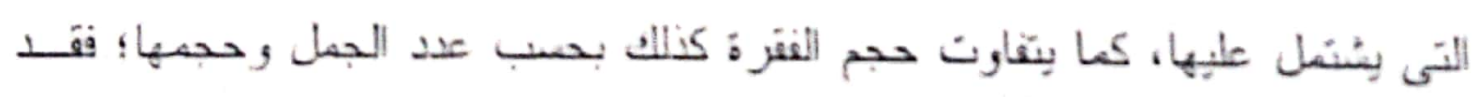
تأتى الفترة مكونة من جبلة واحدة أو جمنتين أو أكثر هن ذلك.وتعدد الفقر ات التـى بنستعل علبها النص بكنف عن نعد الأككار أو المعلومات الجزئية التى ترنبط دلاليا بالفكرة: اللرنيسبة التي بعبر عنها النص.

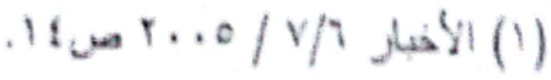

$$
\begin{aligned}
& 100 \text { a } 10 \text { (1) }
\end{aligned}
$$

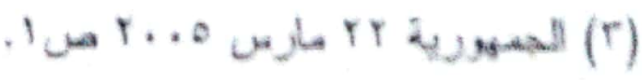




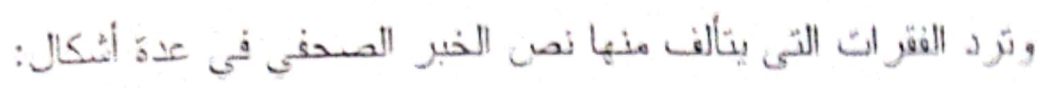

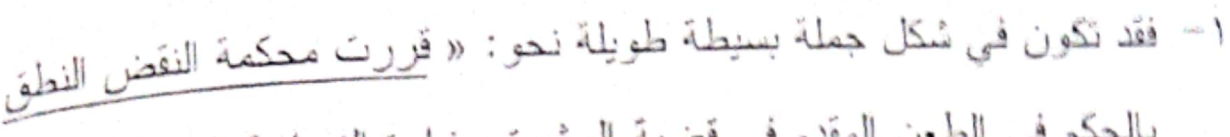

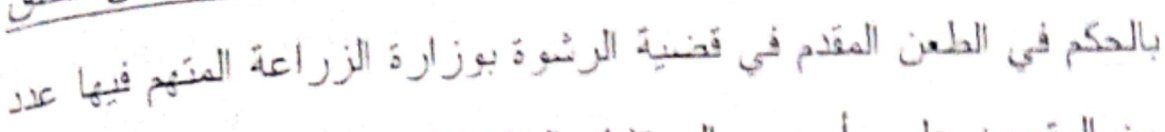

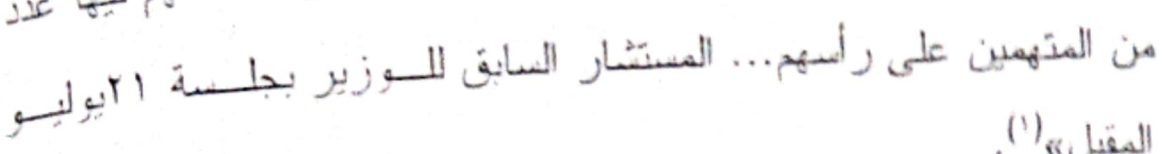
(1) (1) (1)

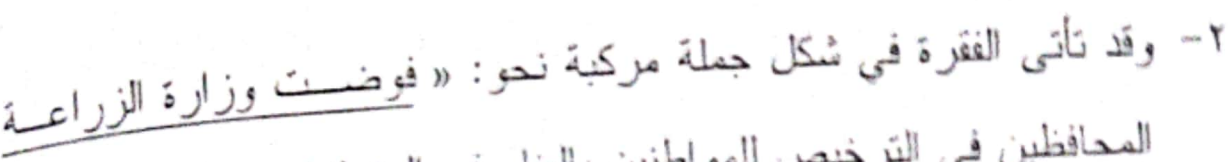

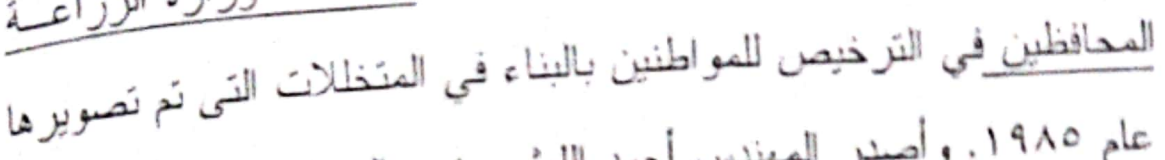

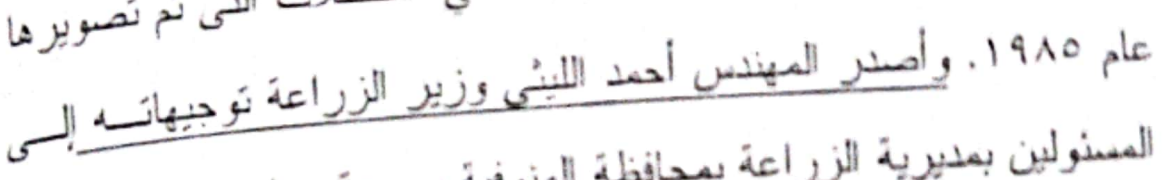

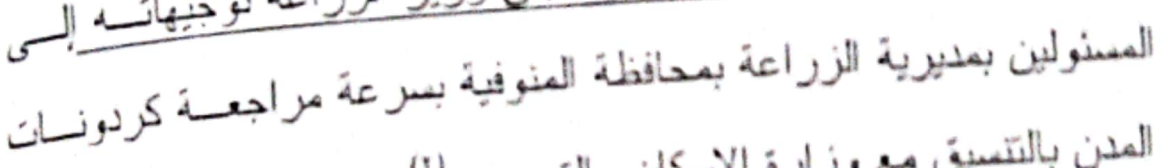

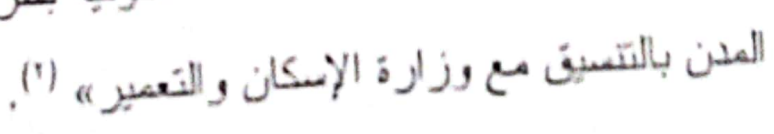

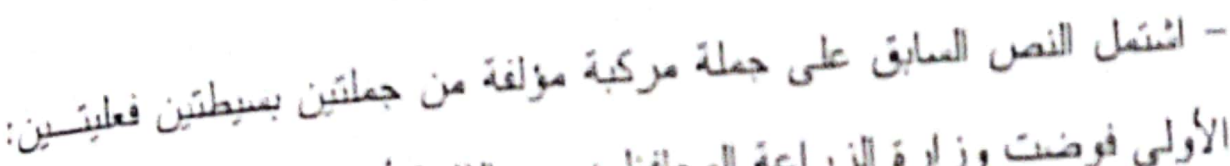

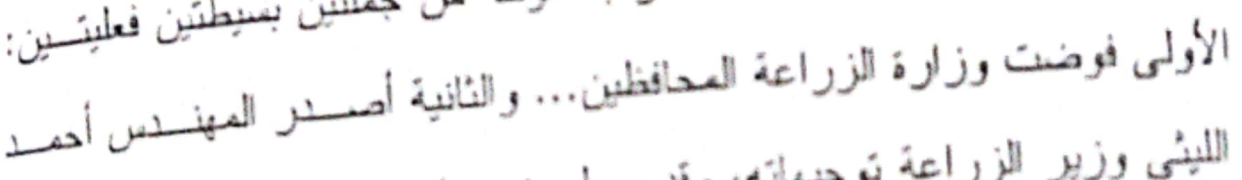

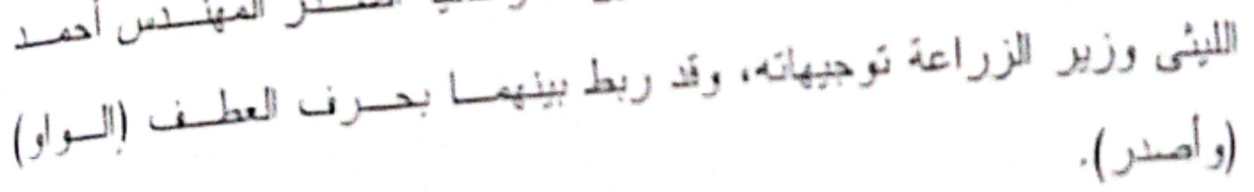

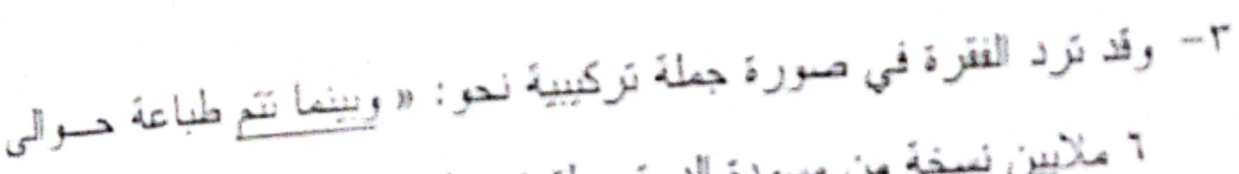

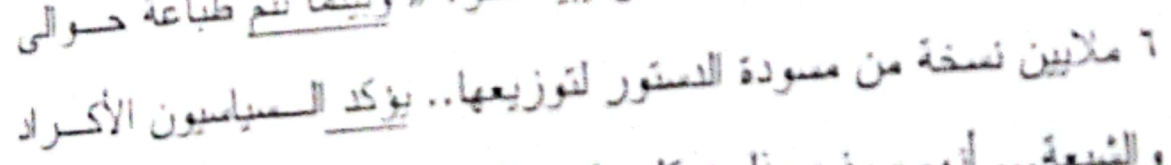

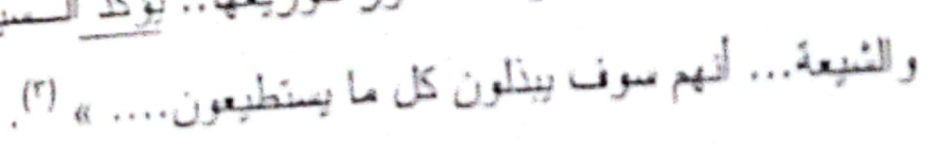

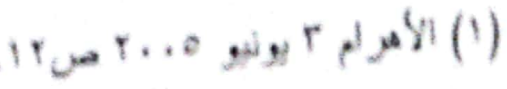

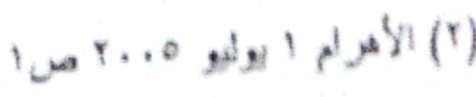

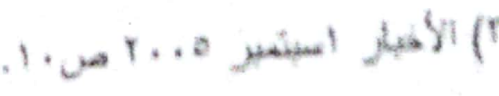




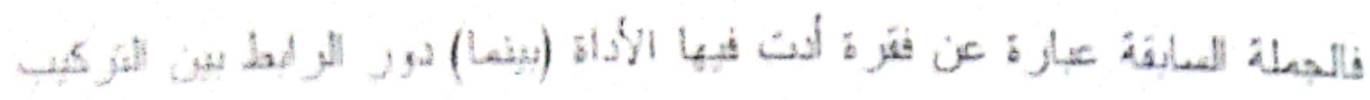

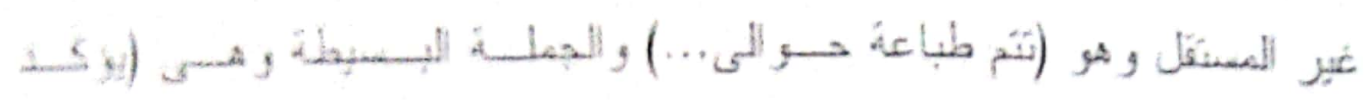

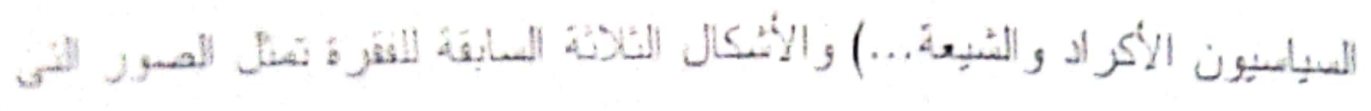 تَبَو فيبها الفترة تَصيرة.}

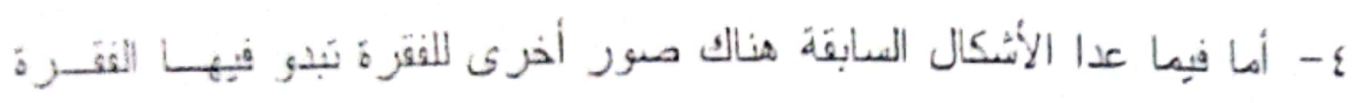

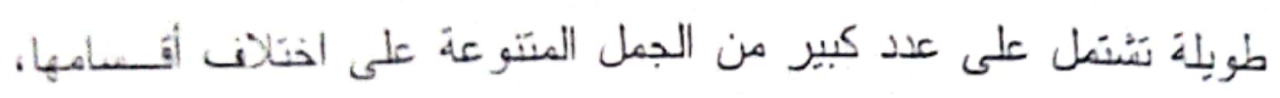
ومن أمتلتها:

" خر ج الطلابِ من اللجان في حالة من البكاء الهيستيرى... قَال الطلاب أحمــ

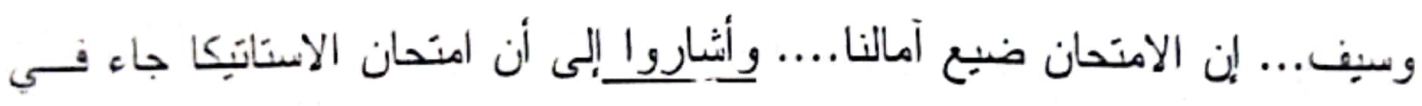
مسنوي الطالب المتوسط... بينما جاء الديناميكا في مستوى الطالب فوف المنتونط.....

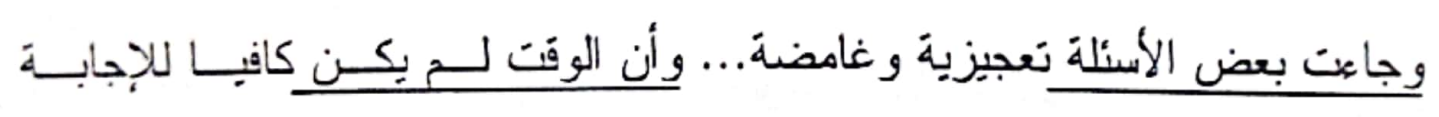
و والمر اجعة (')

الشتملت الفقرة السابقة على عدد من الجمل الفعلية البسيطة التى ربط بينها بـأداة

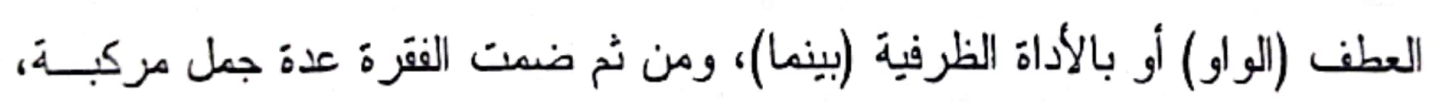
وجملة تركيبية.

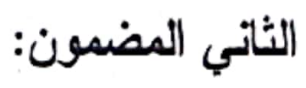

أ- هذا هو الجانب الثني الذي بمكن من خلاله أن نتعرن علـى خـصائص

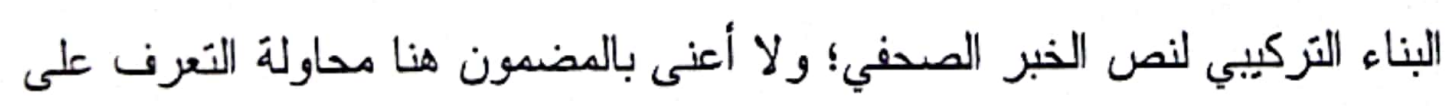

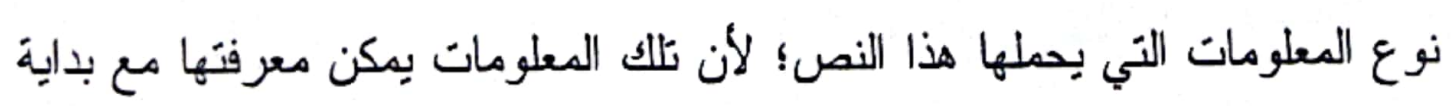

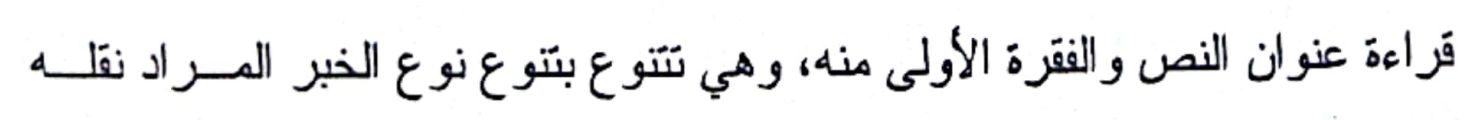

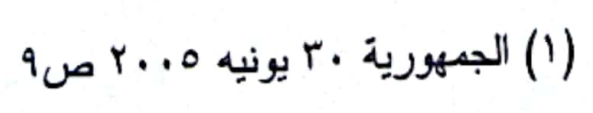




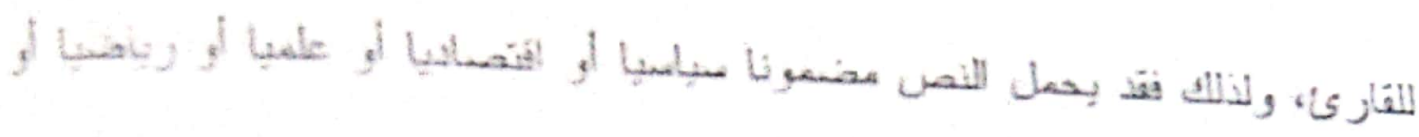

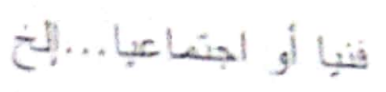

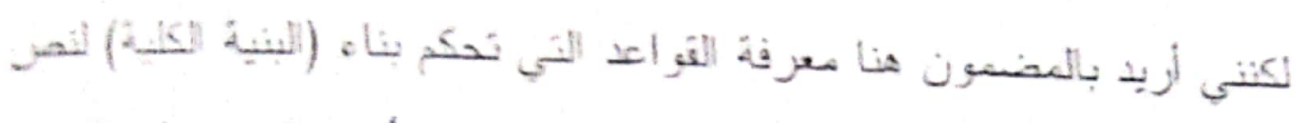

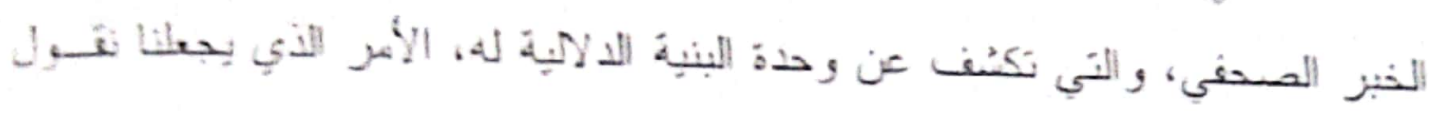

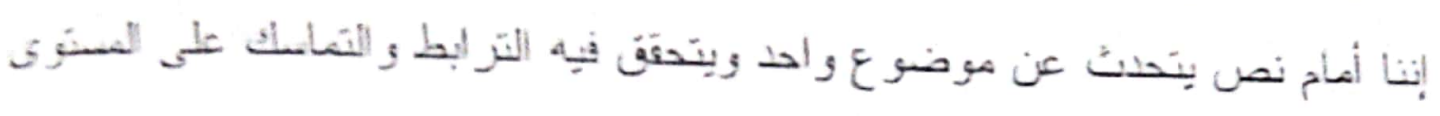
الدالمى.

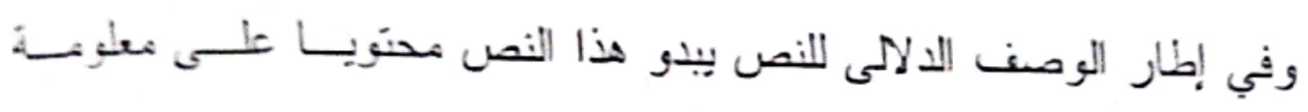

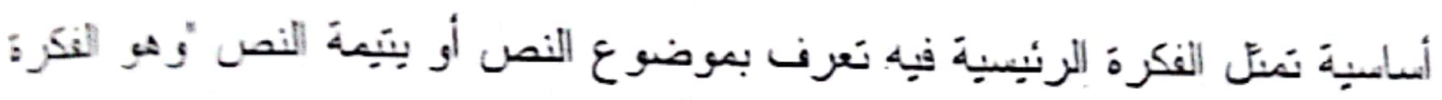

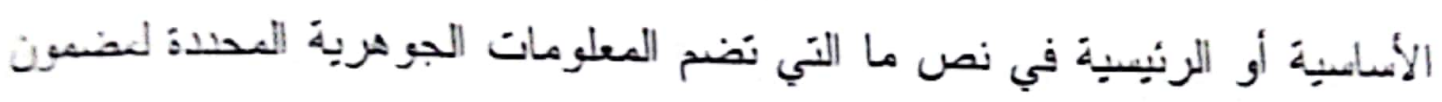

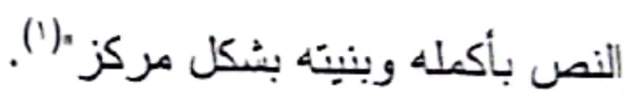

وهناك في النص بالإضافة إلى المعلومة الأساسنة يوجد معلوبـات جزئـة متتائزة على مدار النص كله ترنتط بالمعلومة الأنساسية ارتباطا دلانيا.

ب- أما بالنسبة لنص الخبر الصحفي فإن هناك عناصر معيذة بقَوم طنيبـا

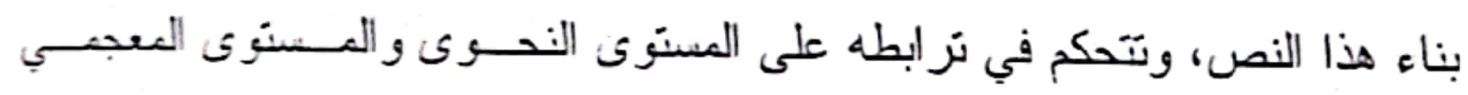
و المستوى الدلالى؛ هذه العناصر هي:

$$
\text { r- r- الحثن }
$$

(1) فولفجانج هاينه مان وآخرون: مدخل إلى علم لغة النص ص؟؟؛. 


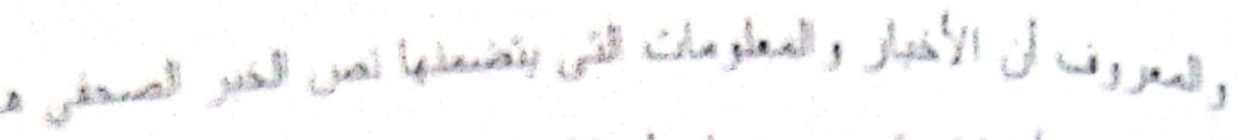

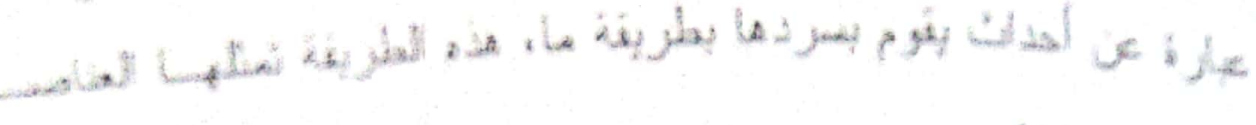
$24+2,3 / 1$

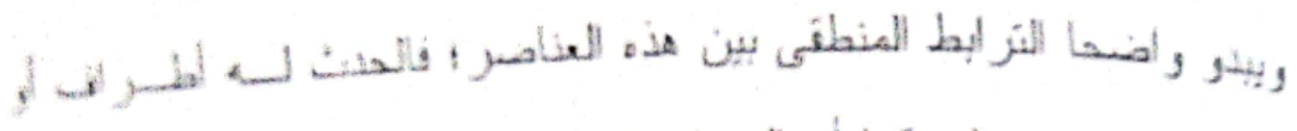

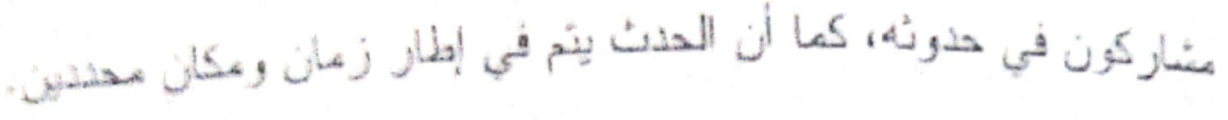

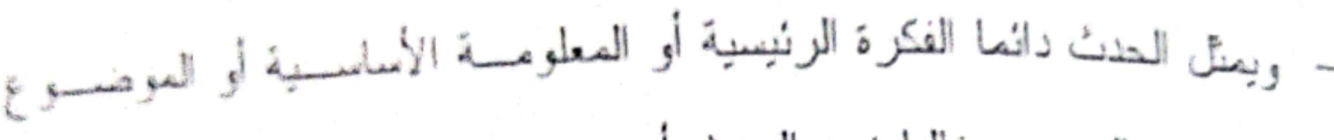

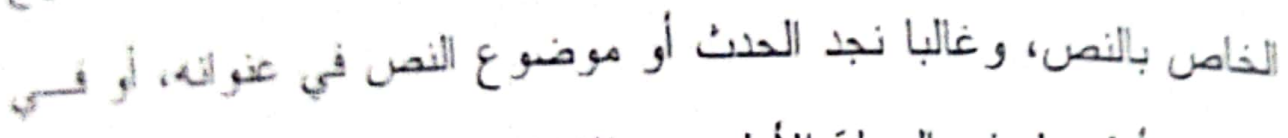

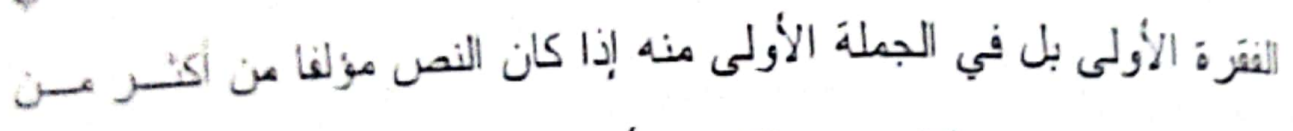

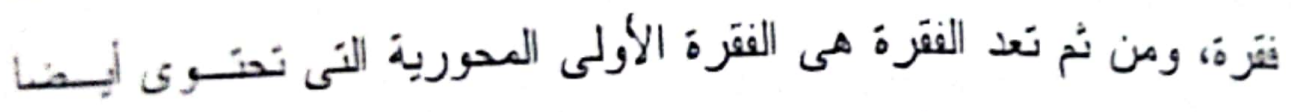
بالإضافة إلى الحدث أو موضوع النص على أطرَات الحنث وزمن الحسـدث. ومكانه.

وإذا كان النص مؤلفا من فترة واحدة فإنتا نجد الحدث أو موضوع النص في عنو اذه أو لا، وفي الجملة الأولى في هذه الفقرة ثُانيا، كما نجد في هذه الجملة أبسـضا

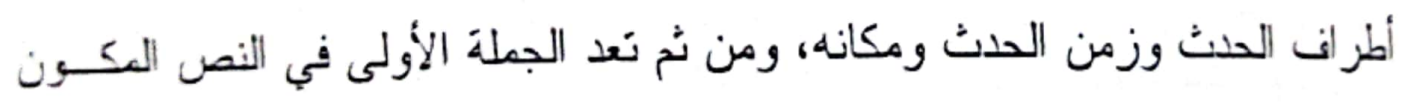
هن فقرة واحدة هى الجملة المحورية في هذا الــص - أمسا المعلومسات الجزئيسة الإضافية في نص الخبر الصحفي؛ فإذا كان النص مكونا من عدة فقزات وجدنا هذه العلومات مختصرة في العنوان أولا، ثُ نعثر عليها بعد ذلك موزعة على فقــرات النص كلها بتفاصيلها.

أما إذا جاء النص في شكل فقرة واحدة فإننا غالبا ما نجد هذه المعلومات أو

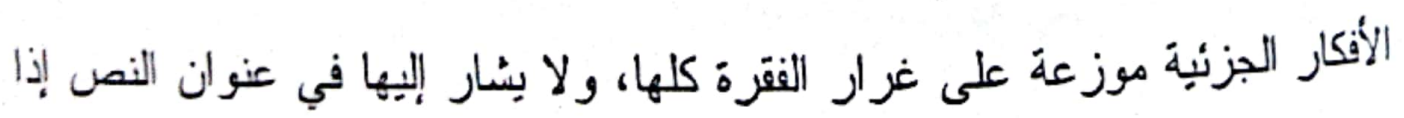

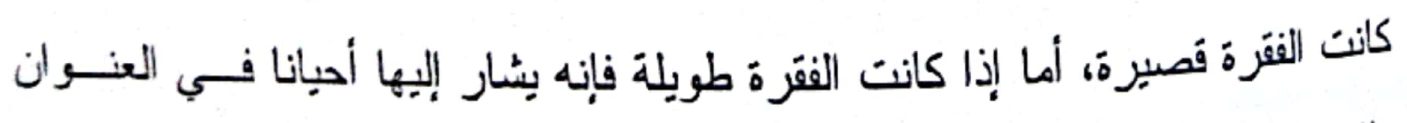
بالإضافة إلى المعلومة الأساسية للنص. 
- و غالبا ما تكون أطر اف الحدث عبارة عن فاعل الحدث، أو المشاركين في صنعه

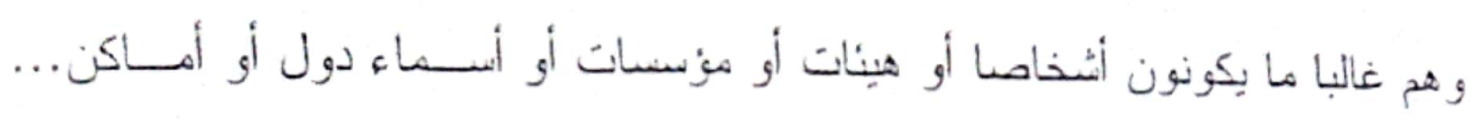
إلخ، وقَ بكون طرن الحدث عبارة: عن مصدر الحدث نفسه؛ كأن بكون وكالة أنباء

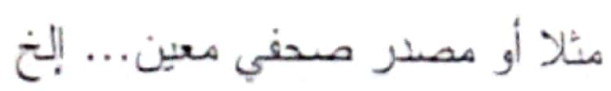

وبمكن أن نلحظ العناصر الأربعة التي يقَّ علبها بناء نص الخبر الـصحفي من خلال عرض النماذج النّلية:

$$
\text { أ- نص قَصبر عبارة عن فقزة واحدةً: }
$$

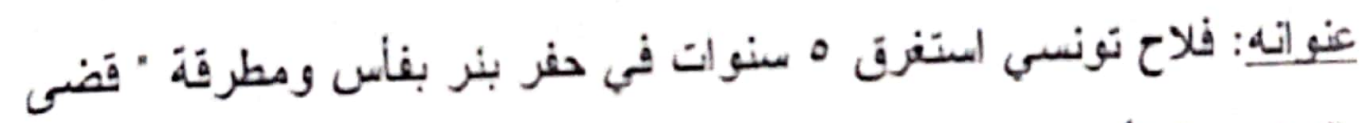

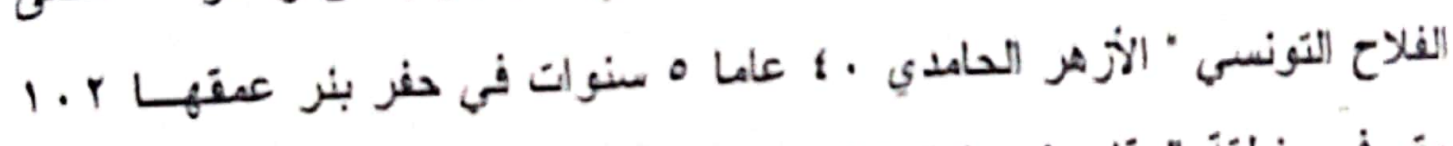

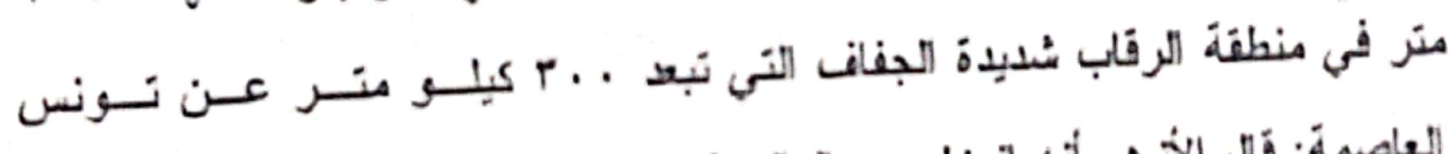

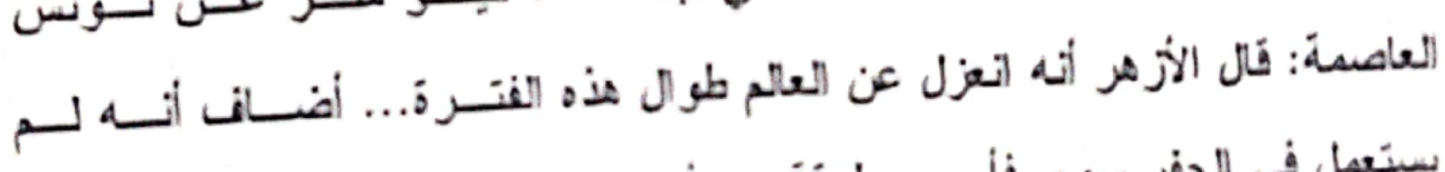

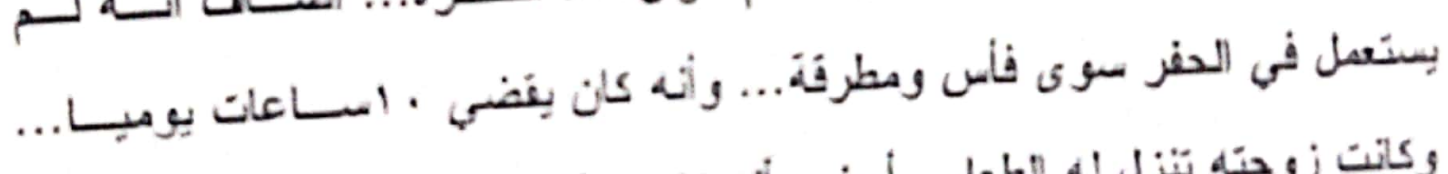

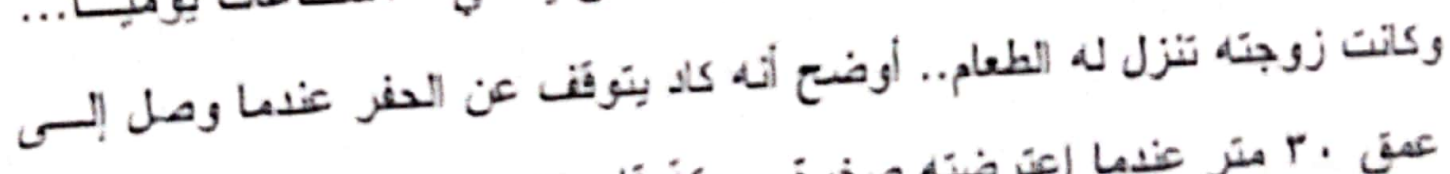

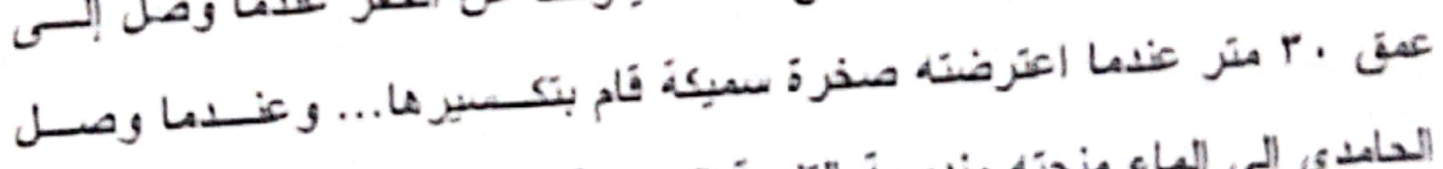

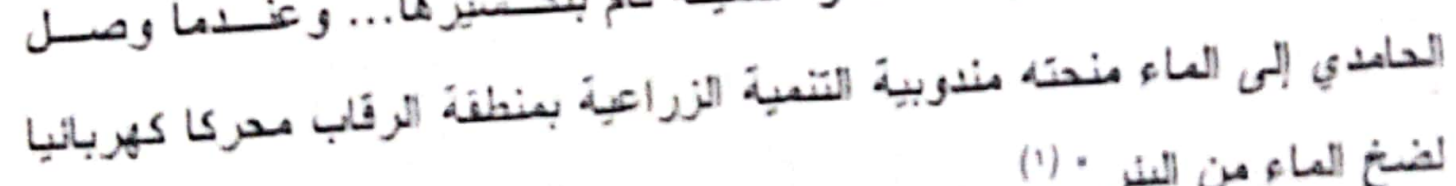

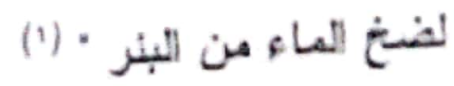

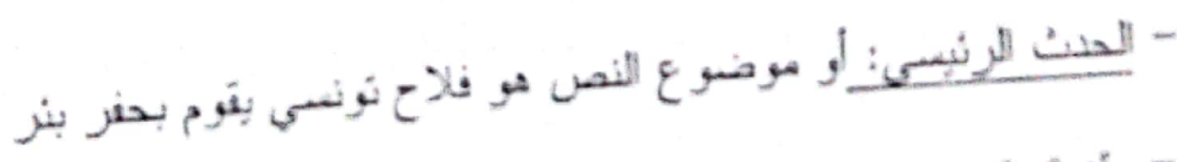

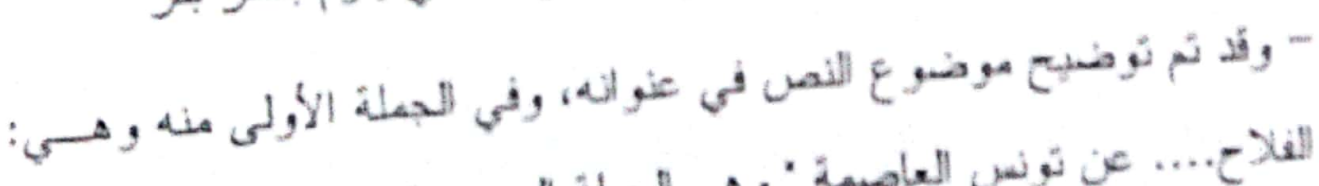

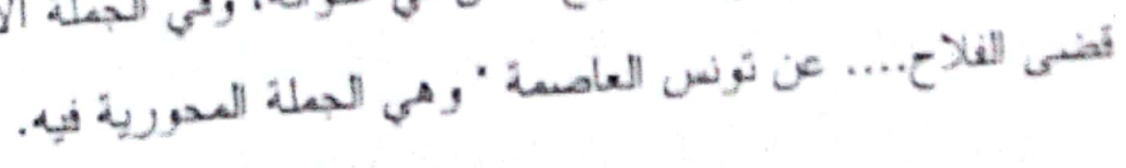


- و اشتمل النص على معلومات أو أفكار جزئبة وز عت على غرار النص كله ولم يتضمنها العنوان لأن النص قصبر - تَّتل أطر انت الحنث هنا الفلاح التَنسي (الأزهر الحامدي) - أما مكان الحدث فيو منطقةَ الرقاب بنَّنس

ب- وغالبا ما يكون النص طويلا مكونا من عدة فقرات إذا جاء في صسورة تقريز أو تحقيق صحفي أو في صورة حديث أو حوار صحفي أو كان السنص هـــ أنس النص الافتَاحي للصحيفة كلها أو للخبار المختلفة في داخلها، ويشتنل عنو انه عندئذ على المعلومات الأساسية فيه بالإضافة إلى المعلومات الإضافية الجزئية وكذلك نجد النوعين من المعلومات في الفقرة الأولى منه.

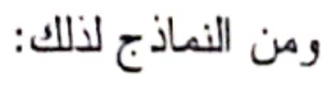

1- نص افتتاحي بعنوان: اللجنة العليا للانتخابات تبحث الموقف مسن حكـم

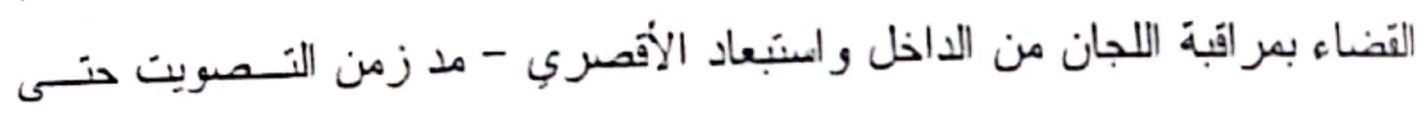
العاشرة مساء.. و انتهاء حملات الدعاية اليوم

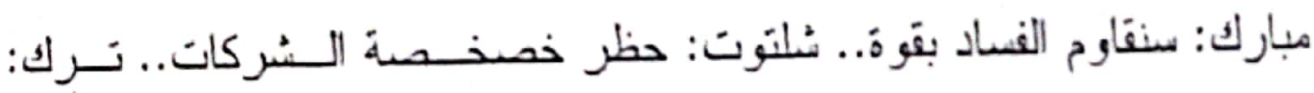
(1) سنتور جنيد خلال عامين النص مولف من عدة فقرات - انُتَل كل من عنو ان النص و الفقرة الأولى منه على المعلومات الأساسية او الأفكار الرنبينة فيه. - مئ. 
- كما تضضمن العنوان المعلومات الإضـافية أو الأفكـار الجزئبــة بسـصورة

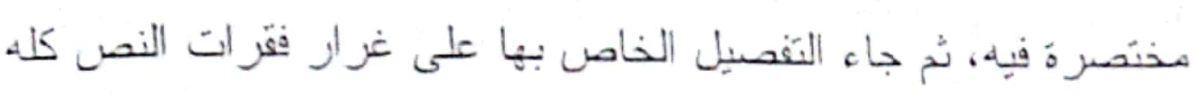
- الحدث الرئبني أو الثعلومة الأساسنة أو موضوع النص هو حكم محكسة

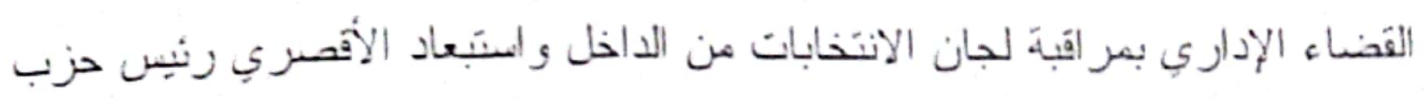
مصر العربي الإنتركي، ومو اصلة المرشحين للانتخابات الرئاسية حملنهم. - أما أطر ان الحسث فهم: محكمة القضاء الإداري - و اللجنة العبا للانتخابات - و الأمين العام للجنة العليا للانتخابات ورحبد الأمصر بي - ومرسنحو الانتخابات الرناسية.

$$
\text { - مكان الحدث هو الإسكندربة - }
$$

- زمن الحلث تم النعبير عنه في الجملة الأولى هن النص وهي: " أصسلرن محكمة القضضاء الإداري بمجلس الدولة أفس حكمن هيمين... r-ونص أخر جاء في صورة نقرير عن مونتر الفة العربية

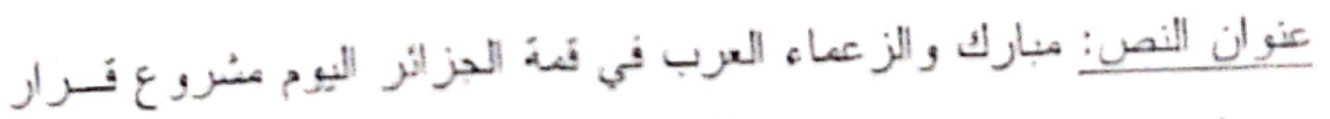

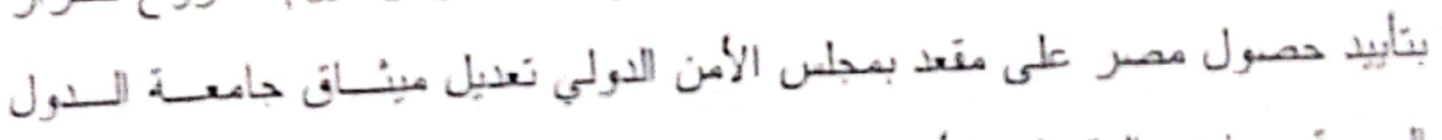

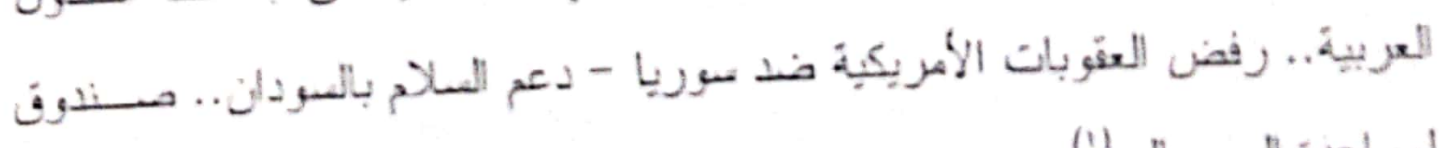

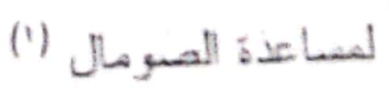

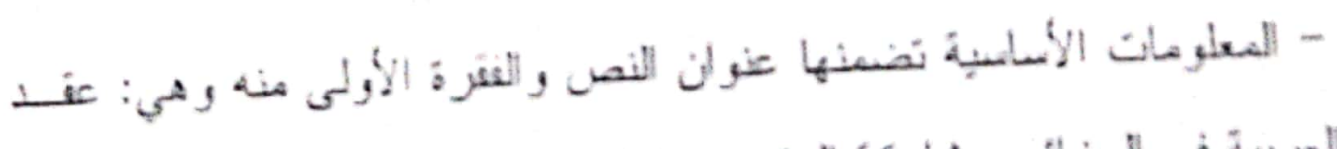

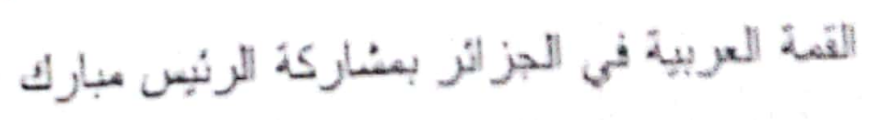

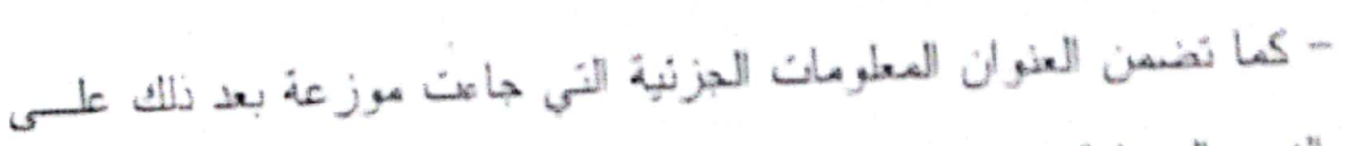

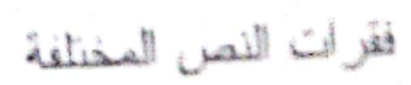

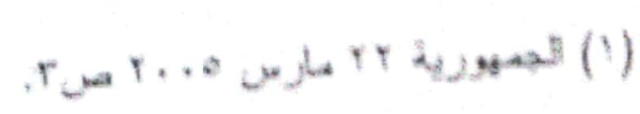




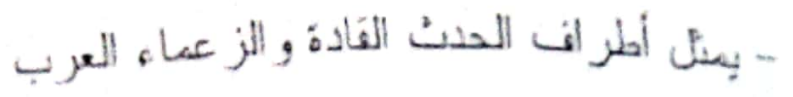

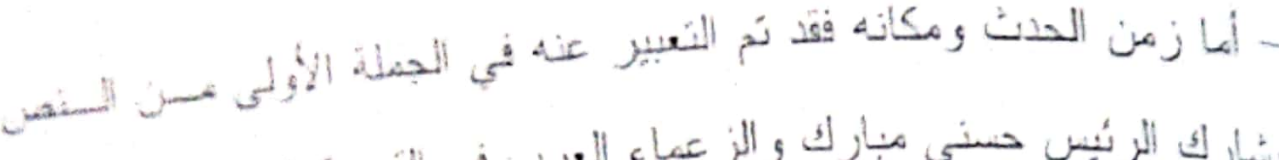

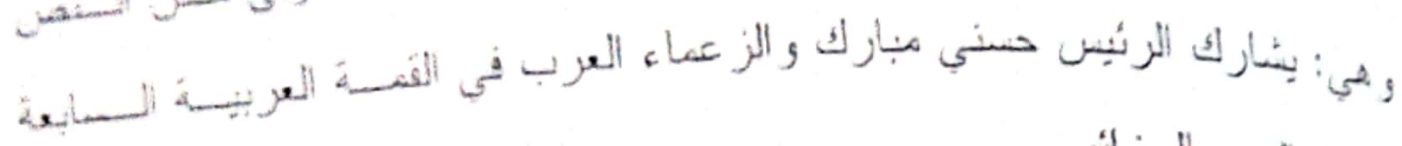
عنزة البيو مبالجز ائر. 


\section{المبيثيث البئاليث}

\section{اليتزابط النيدوي ني نص الفبر الصحفي المين}

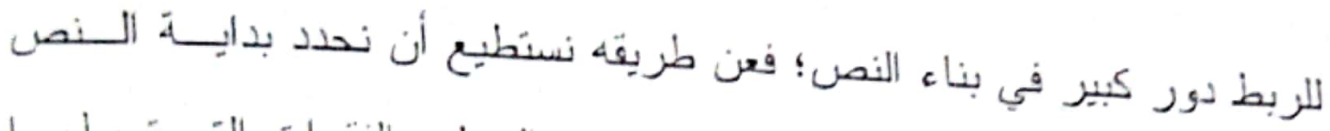

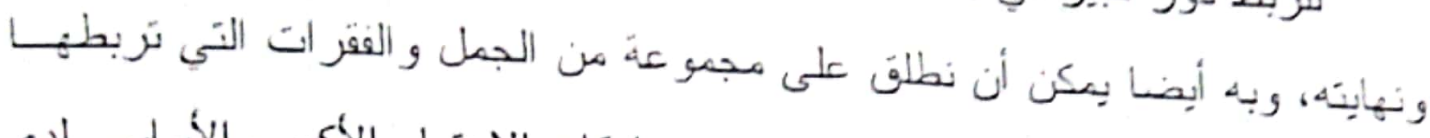

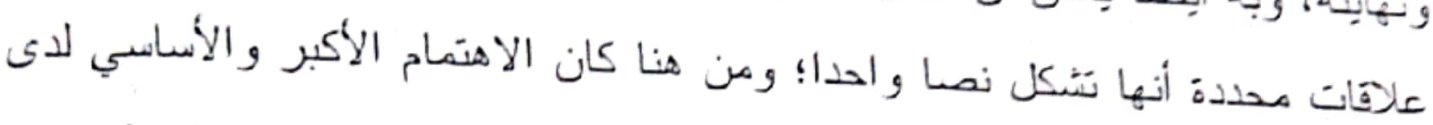

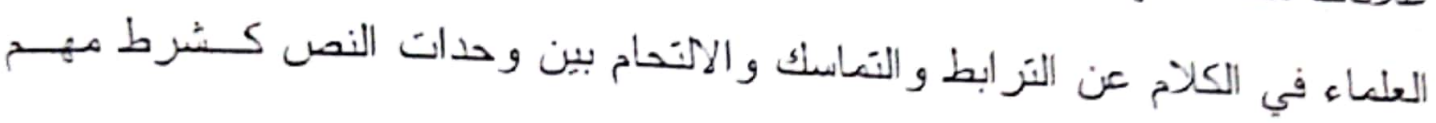
الإثبات نصبة النص

ولا شكك أن أى خلل في مجال الربط بين الوحدات الداخلية للـــص سـيؤدي

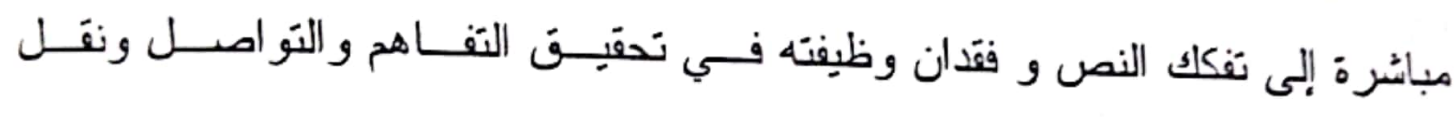

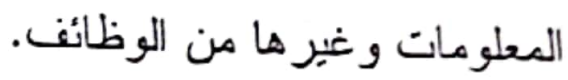

و البحث في التزرابط على مستوى النص لا يقتصر على النظر إلـى التــرابط

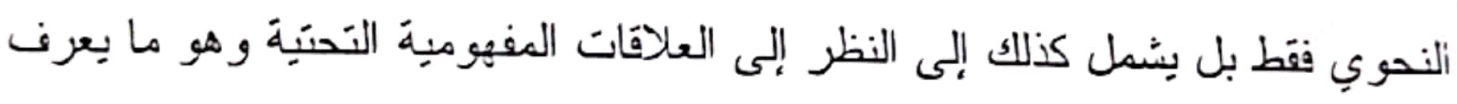

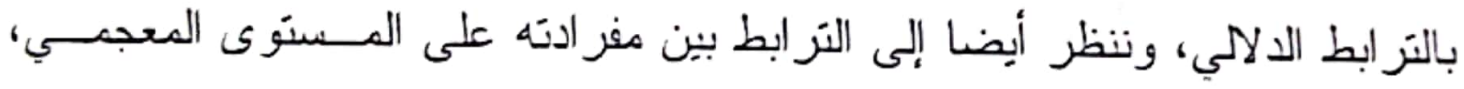

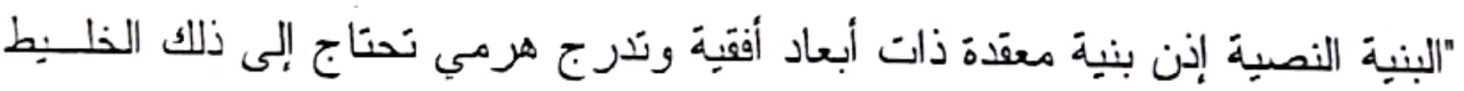

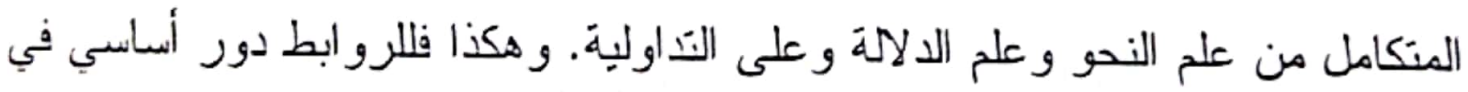
تشكيل النص سو اء كان ذلك بين جمله أو مفرادته"(') وسوف يعرض البحث للترابط النحوي في وحدات نص الخبر الصحفي هـن خلا الجملة و الفقرة ومن خلا النص بصفة عامة: 


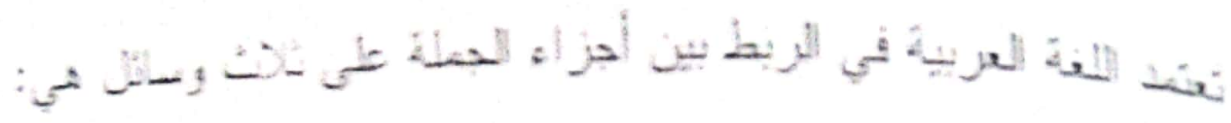

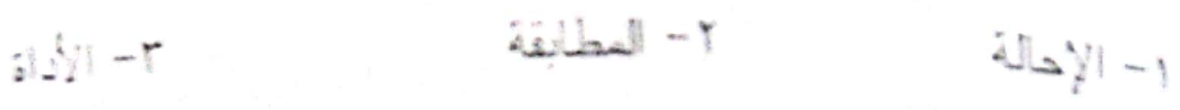

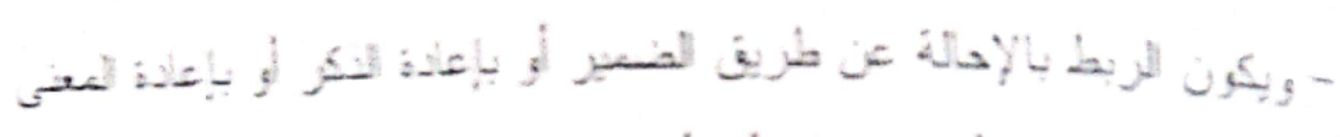

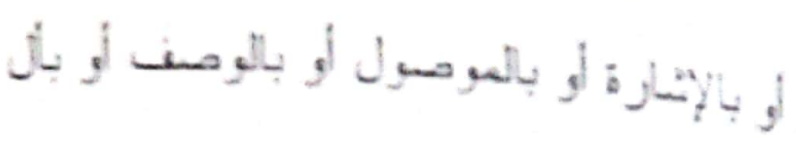

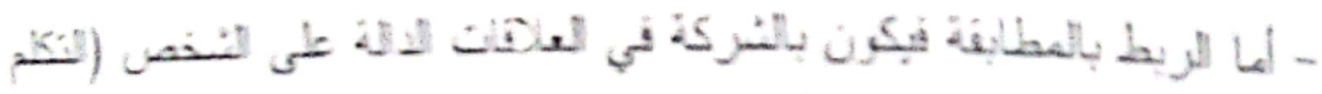

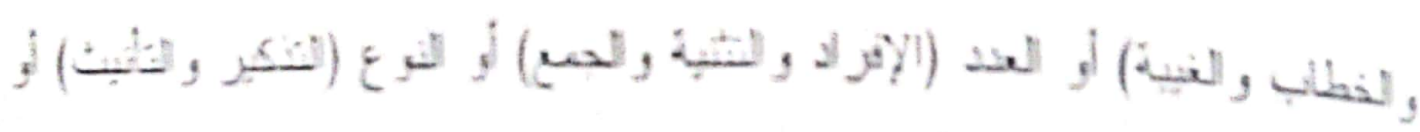

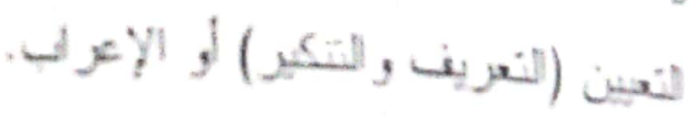

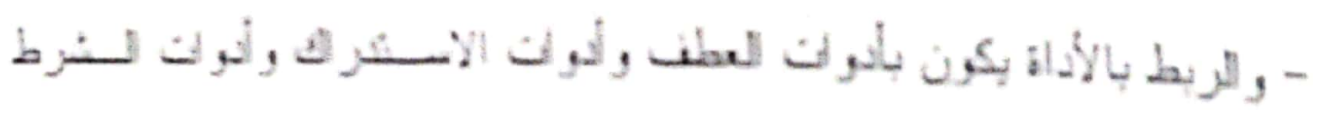
(1) I L et,

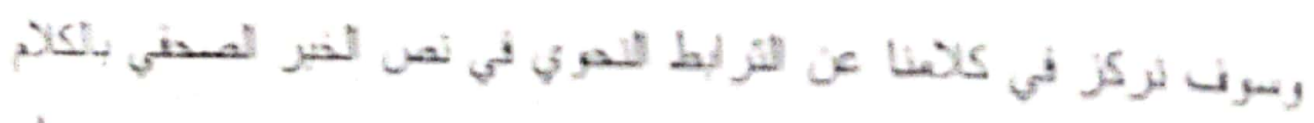

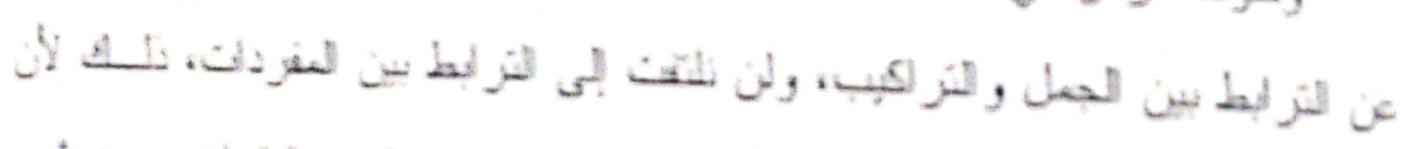

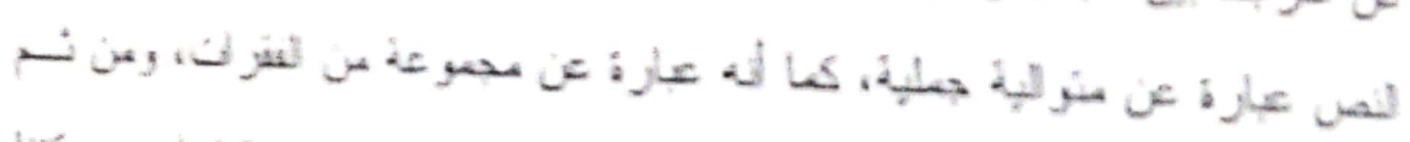

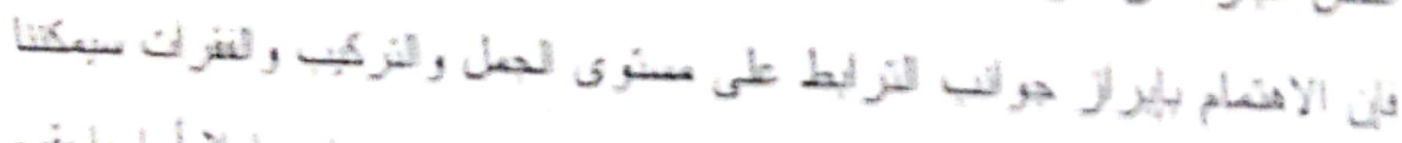

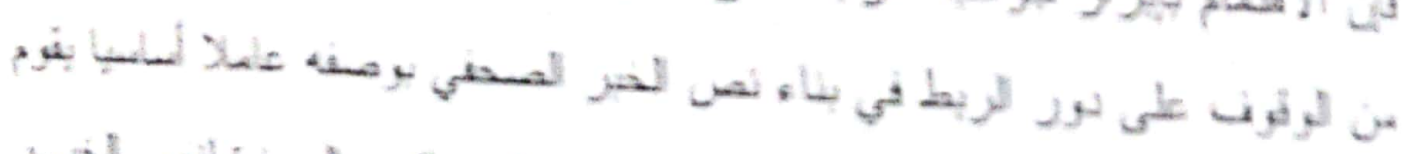

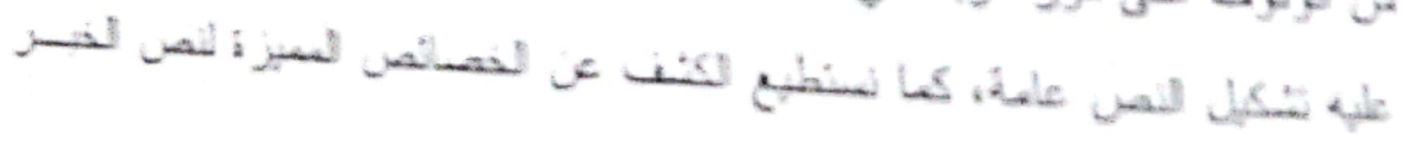

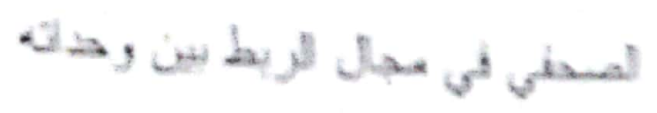

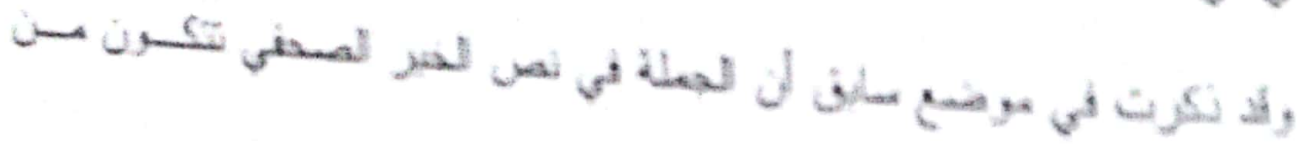

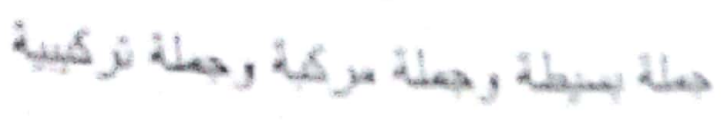

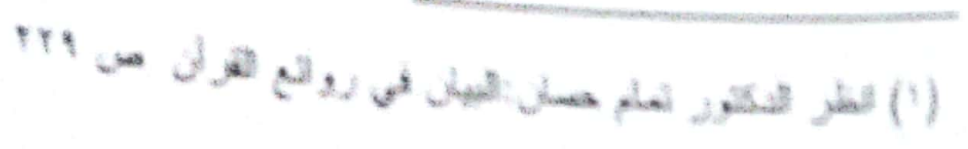




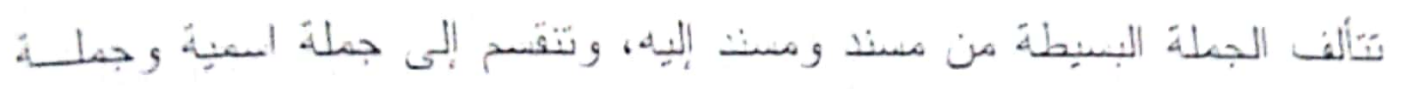

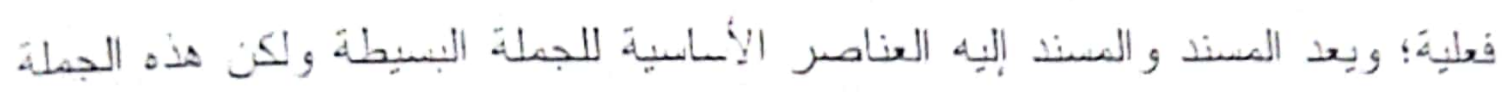

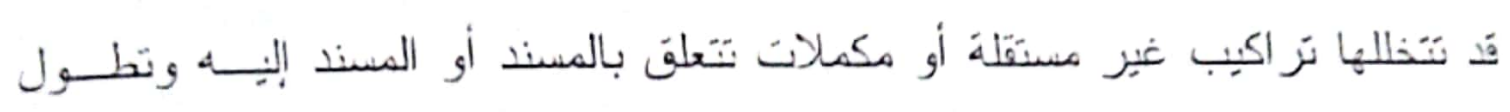
الجلة البنيطة من خلالها.

و هذه التز اكيب غبر المنتقلة من سماتها أنها تأتي في شكل منتسمنة شكل أكبر

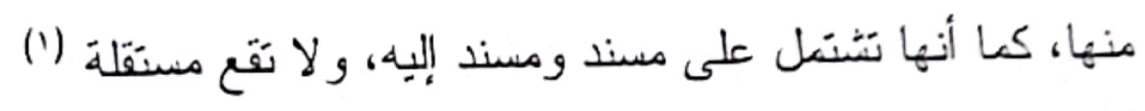

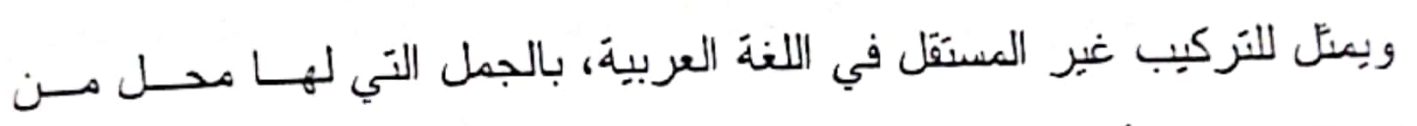

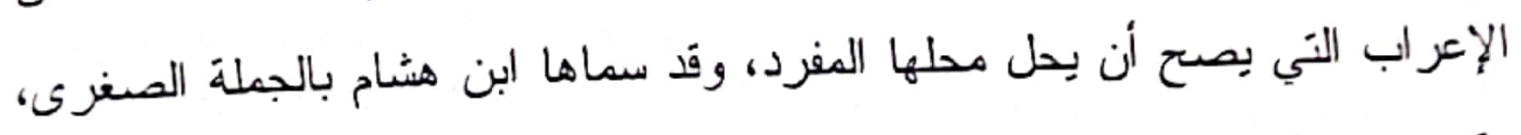

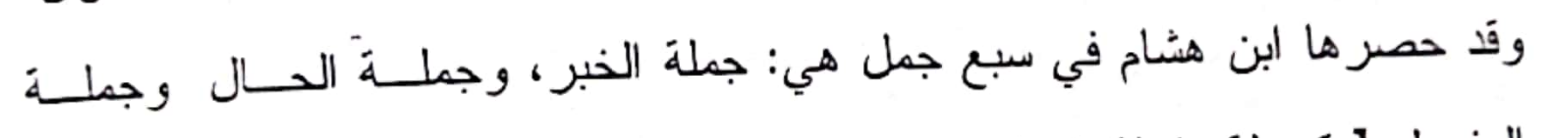

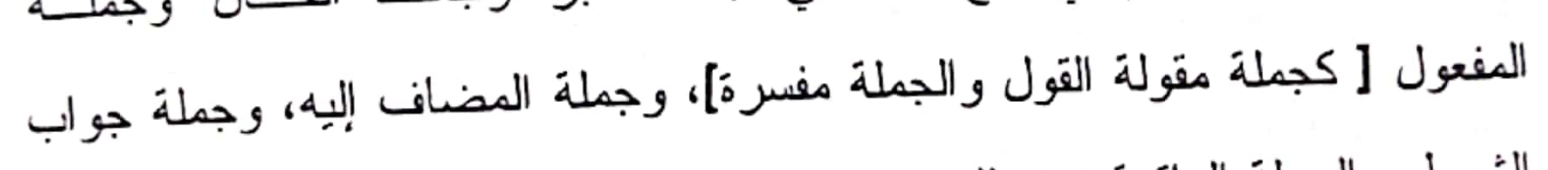

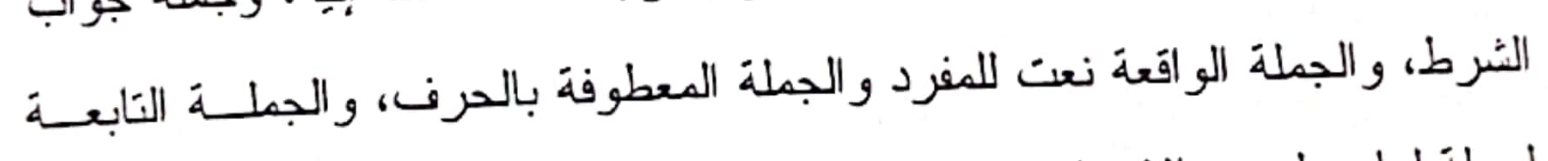

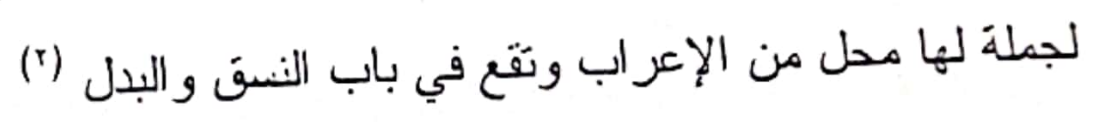

ونقدم أمتلة من هذه التر اكيب غير المنتملة لنتعرف على وسائل الترَبط بينها وبين ما تَعلق به في نص الخبر الصحفي.

1- التركيب الواقع خبرا في الجملة الاسمية المجردة ومن أمثلته:

- هذه المسألة لا يجب أن بطلع علبها سوى مسئولي الأهلي -

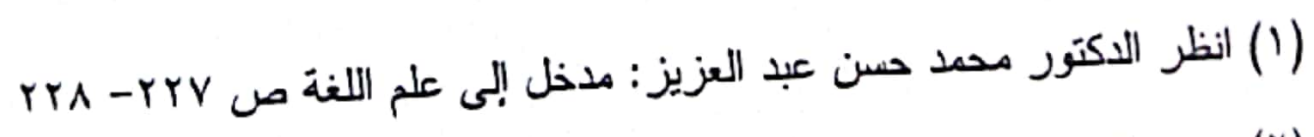

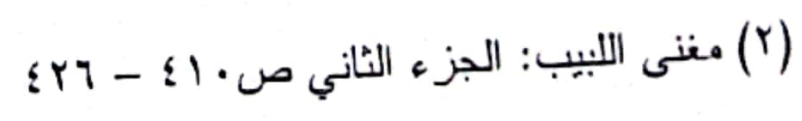

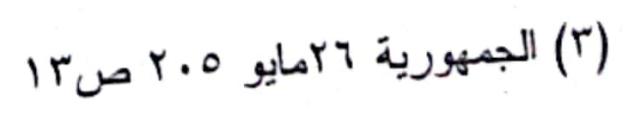




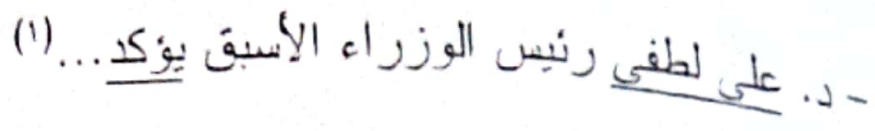

$$
\begin{aligned}
& \text { في المنالين السابقين جملتَان اسميتّان نتكونان من: } \\
& \text { منسا (تركيب غبر منسنكل) } \\
& \text { لاجب أن بطلمع عليها } \\
& 4 \text { بn } \\
& \text { is } \\
& \text { يوكي } \\
& \text { لـ. - ملى لطفي }
\end{aligned}
$$

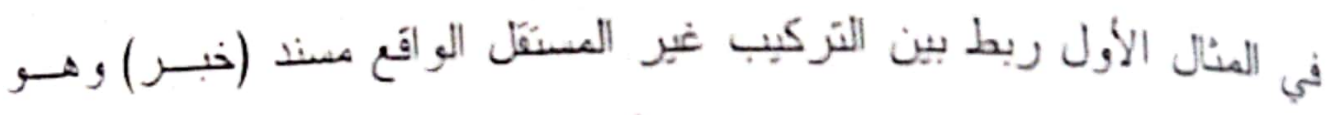
عبارة عن جملة فعلية وبين المسند إلبه (المبنكأ) عن طريف الاحالة بضمير الغائبس الأب لدف بحرن الجر على (علبه) الأي يعود على كلعة المسألة

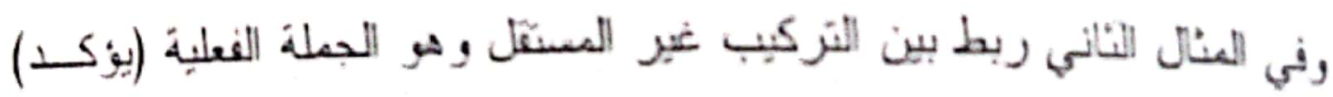
اله انع خبرأ بالمسند إليه (المبندا) و هو كلهة: (علي لطفي)، عـن طريسـن الإحالـة بالضعبر الفائب المستر في لفعل (يوكـ).

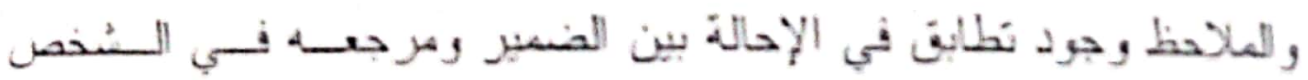

$$
\text { والثر ع العند والنعين }
$$

r- التركبب المو القع خبر أ للجبة الاسعبة غير السجرية ومن أمثلته:

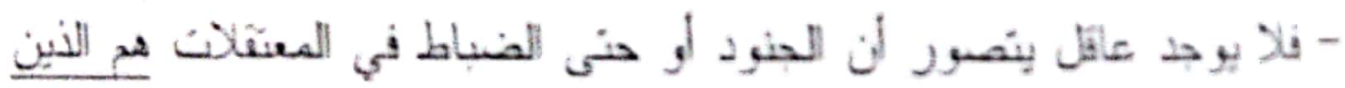
(1)

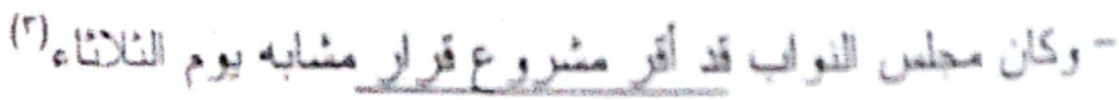

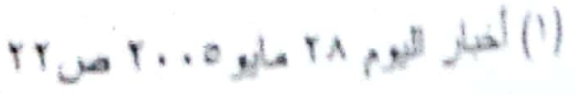

$$
\begin{aligned}
& \text { r... } \\
& \text { luar... }
\end{aligned}
$$




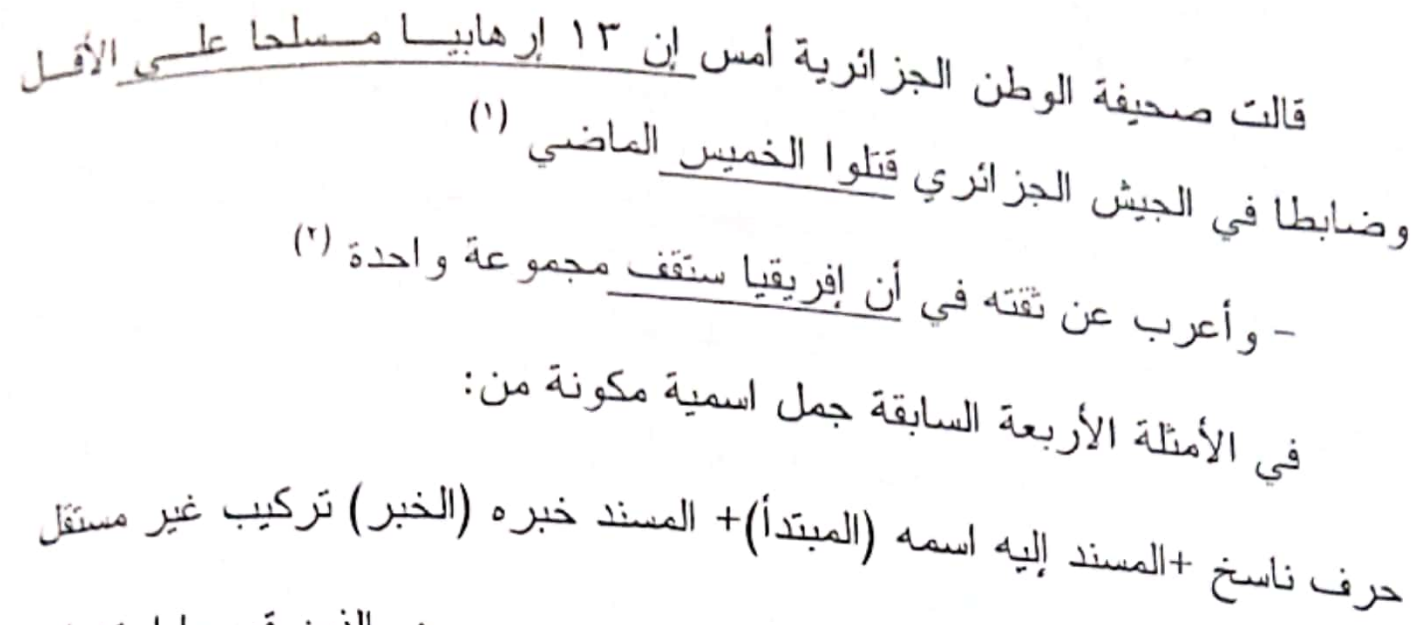
هم الذين قَرروا استخدام..

$$
\text { كان }
$$$$
\text { الجنود }
$$

ستقف

\section{إفريقيا}

في المثال الأول ربط بين المسند إليه و التركيب غير المستقل الواقع مسنداعن طريقن الإحالة بضمبر الفصل هم وضمير الموصول (الذين) وضمبر واو الجماعسة

$$
\text { المنصل بالفعل (قرروا) }
$$

- في المثال الثاني تم ربط التركيب غير المستقل (قد أقــر ) بالــسنـ اليِـه بالإحالة بالضمير المستر في الفعل أقر. - وفي المثال الثالث ربط ضمير واو الجماعة المتصل بالفعل (تَلوا) الواقــع مسندا وهو التركيب غير مستقل ربط هذا التركيب بالمسند إليه

$$
\begin{aligned}
& \text { (1) الأخبار } 7 \text { يوليو o... }
\end{aligned}
$$

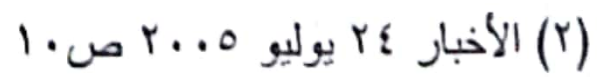




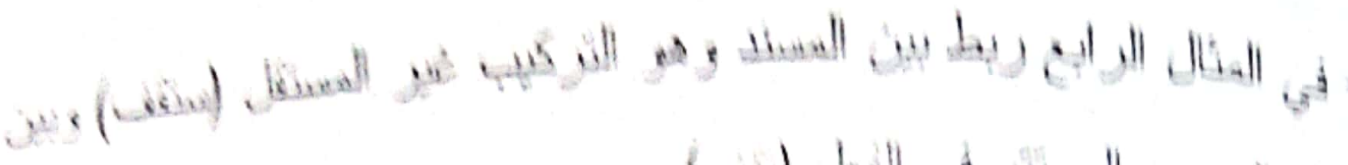

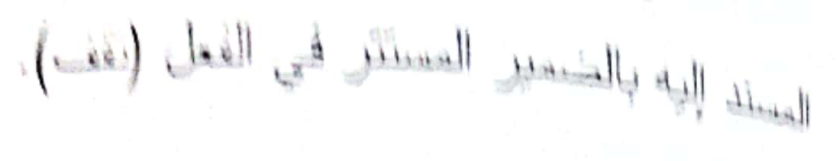

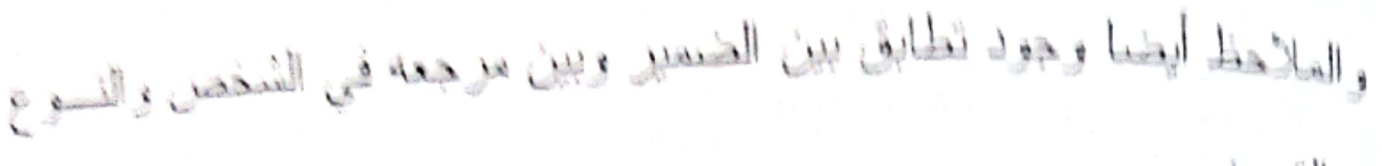
incill, dist,

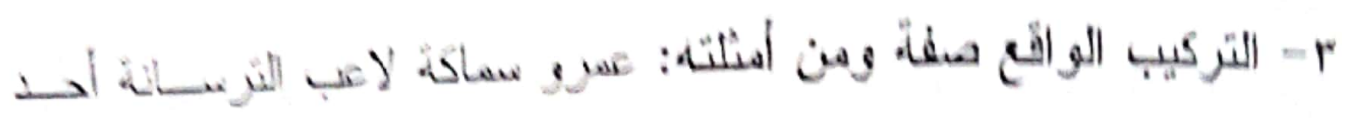

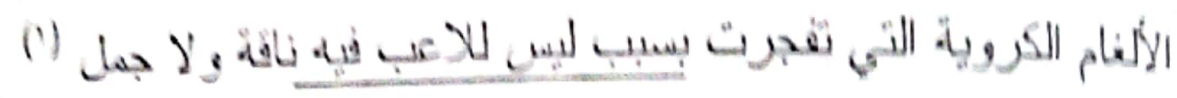

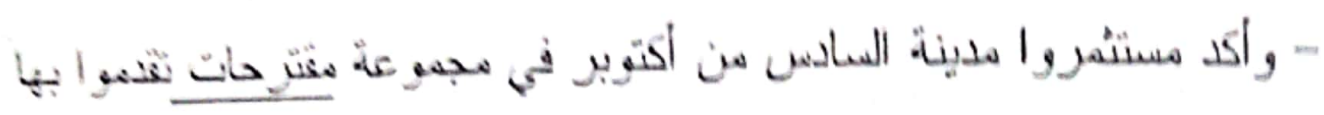

(للاكتور الحمد نظيف وكد

في المثال الأول وقعت الصفات تركيا اسميا غبر سمثنل (لبس للاعب فــــ.)

وقد ارتبط بالموصوف وهو كلمة (بسبب) عن طريق الإحالة بالضمير الــني لحستِ

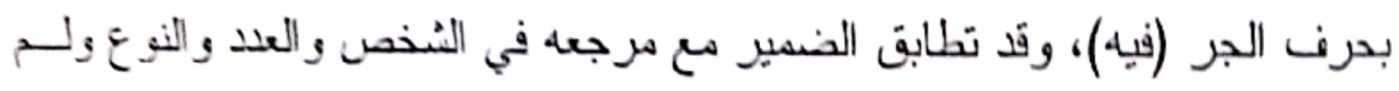

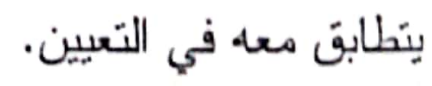

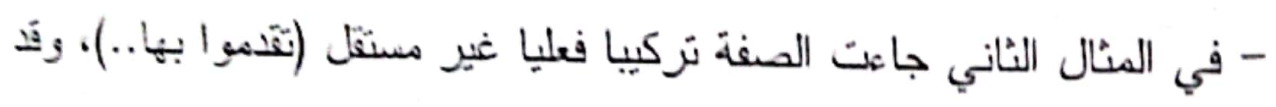
ارتبط بالموصوف وهو كلمة (مقترحات) عن طريق الإحالة بالضمير الــني لهـنق

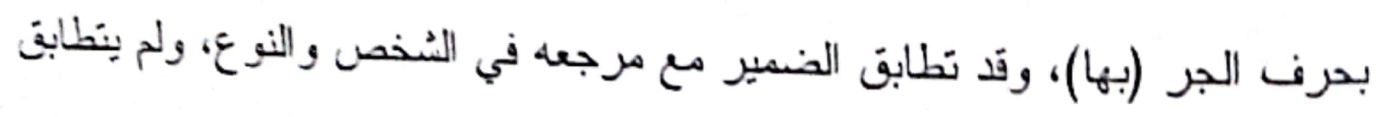

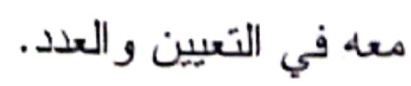

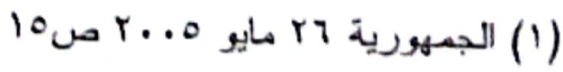

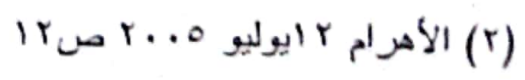


؛ - التركيب الو اقع حالاومن أهثلته:

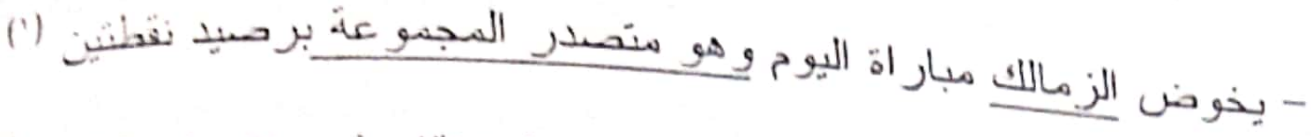

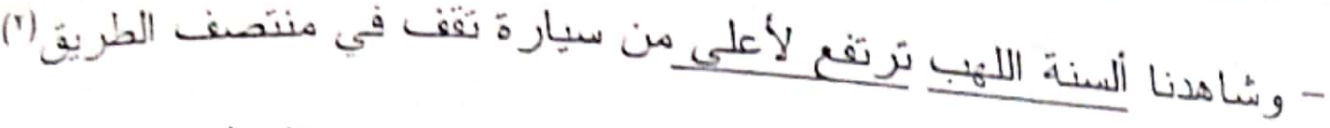

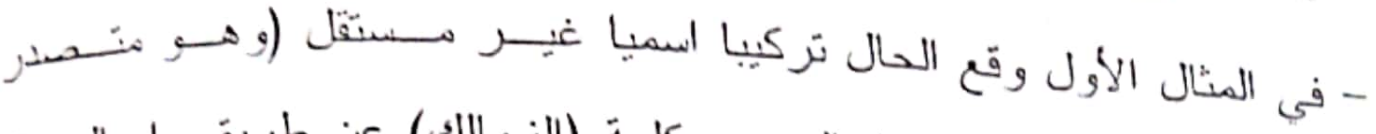

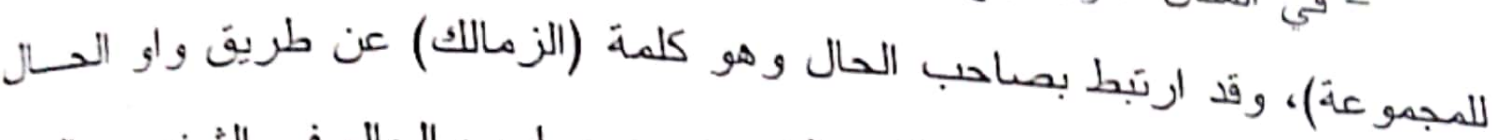
والاحالة بالضمير (هو)، وقد تطابق الضمير مع صاحب الحال في الشخص و النوع و العدد و التعيين

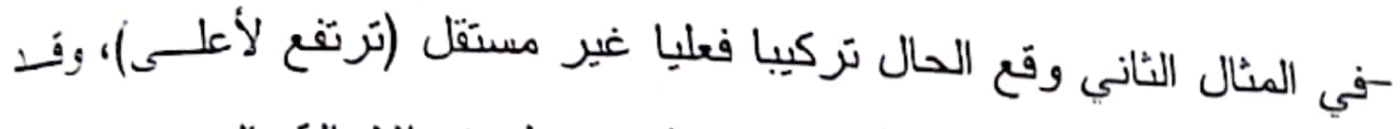
ارتبط بصاحب الحال وهو كلمة (ألسنة اللهب) عن طريق الإحالة بالضمبر المنشتر في الفعل (ترتفع) وقد تطابق هذا الضمبر مع صاحب الحال في الــشخص و النسّوع و العدد و التعيين

ه- التركيب الواقع صلة ومن أمثلته:

- أضاف أن يجري حاليا تطوير وتبسيط الإقرار الضريبي بما يتَّ افـنق مسع

الفكر الجديد الذي تَبناه الوزارة إنان

- أكذ مدير البطولة أن الملاعب تم تسليمها لإدارة الأشغال العـسكربة التـى

بدأت في تأسيسها (؛)

$$
\begin{aligned}
& \text { (1) الأخبار ؛ ب يوليو o... }
\end{aligned}
$$

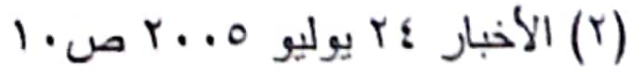

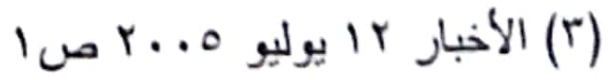

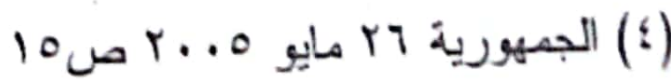




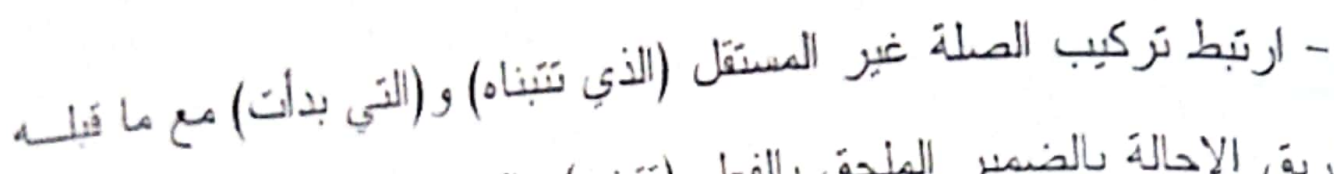

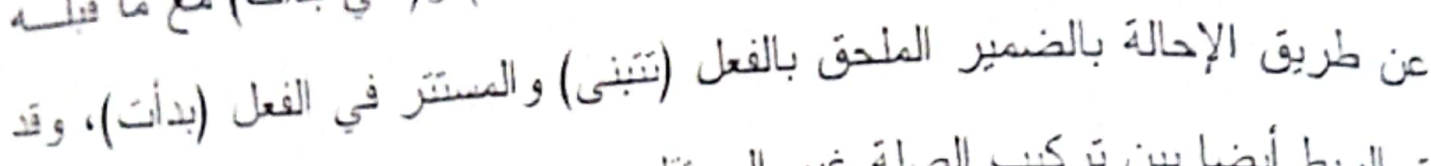

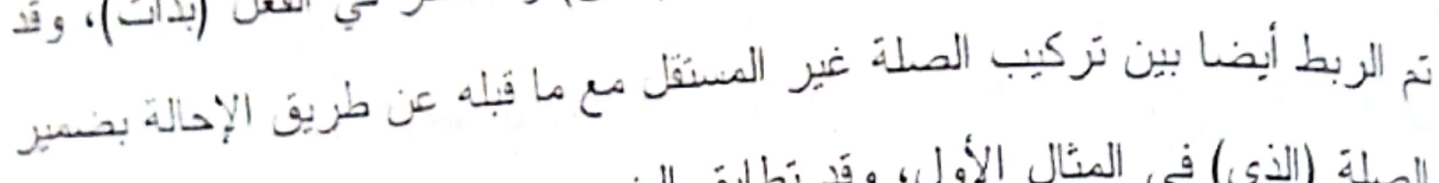

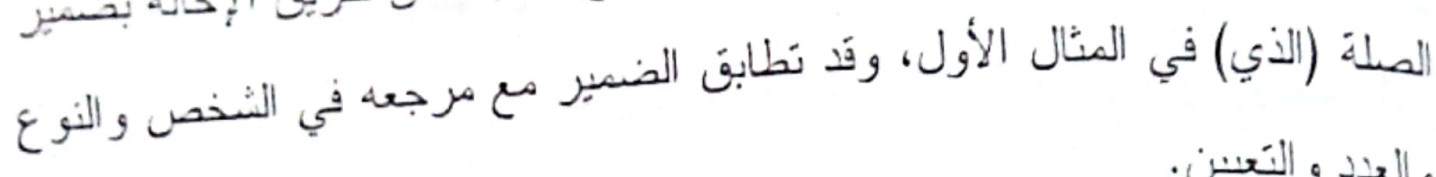
و العذد و التنبِينِ.

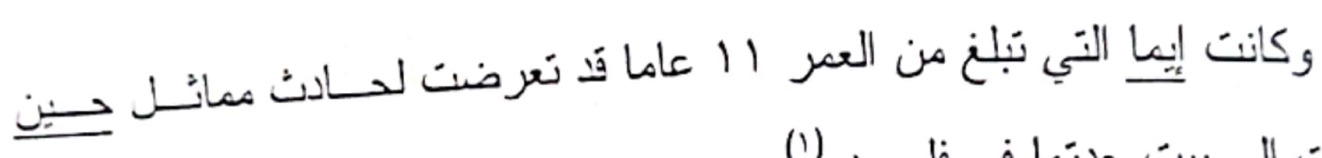

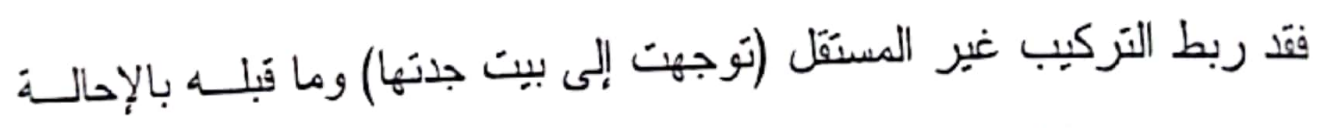
بالضمير المستر في الفعل نوجهت و الضمير الملحق بكلمة جدنها.

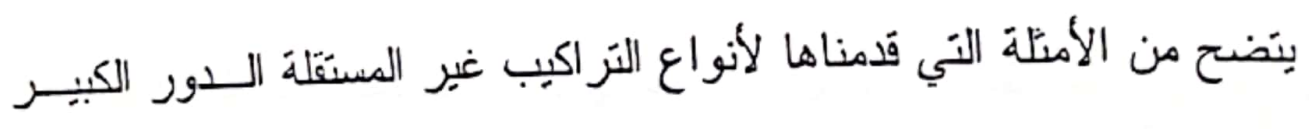

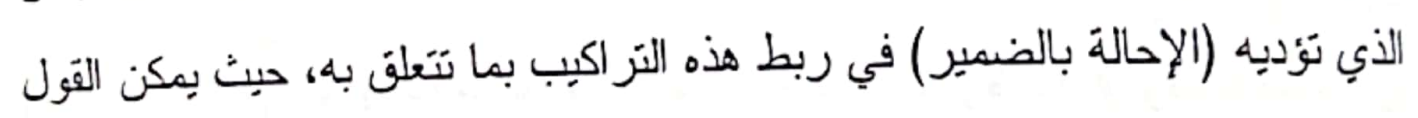

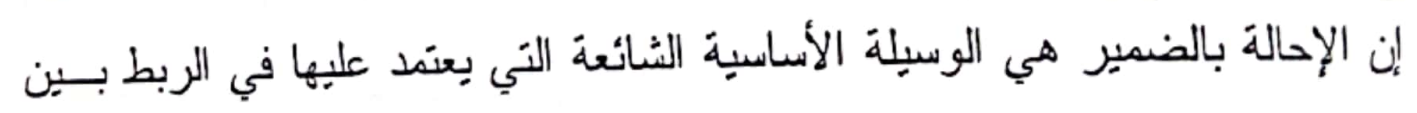

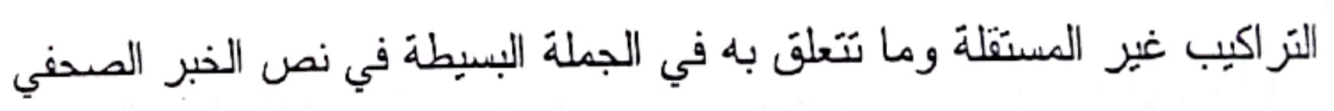
وقد بعنمد على وسائل الإحالة الأخرى ولكن بقلة نحو : - و أكلد.. علدم مطالبة البنوك بالتغطية الكاملة حيث بـؤدي مطالبـة البنــوك

بالتنطبة الكاملة إلى عدم استخدام هذه التسهيلات (r)

$$
\begin{aligned}
& \text { (1) أخبار اليوم } 17 \text { يوليو Y... }
\end{aligned}
$$

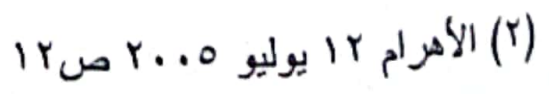




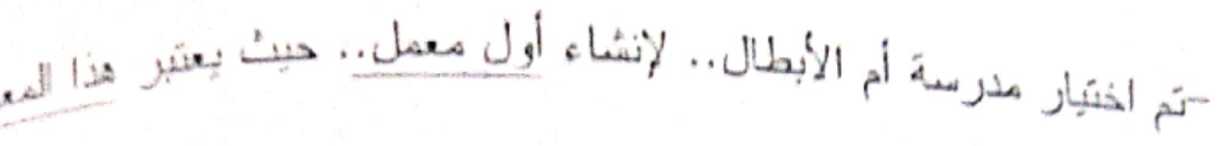

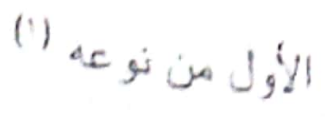

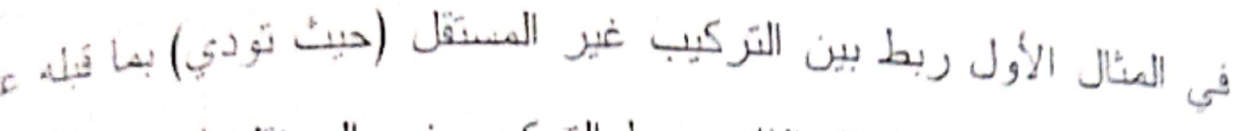

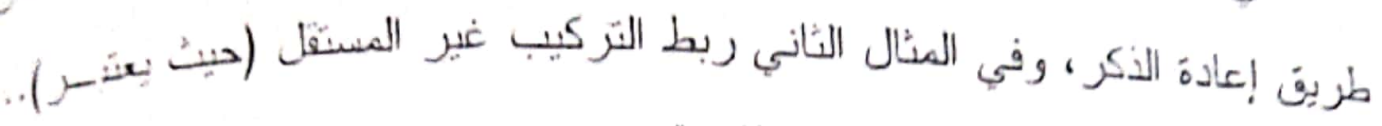

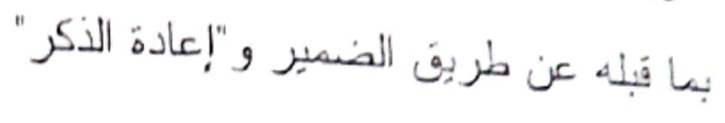

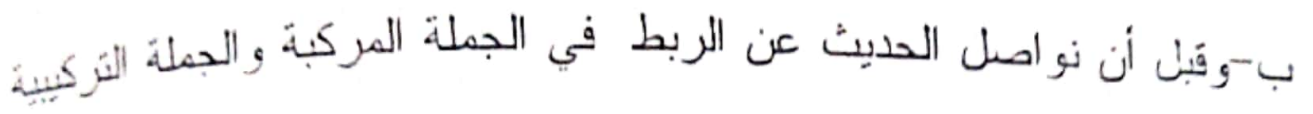

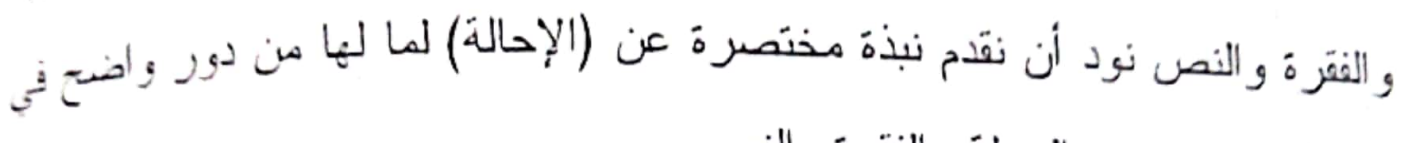

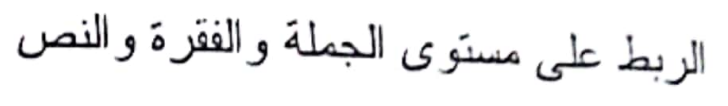

\section{1- تمريف الإحالة REFERENCE:}

عرفها الدكتور تمام حسان بانها ما " يُشتمل اللاحق على ما يُشير إلى السابن

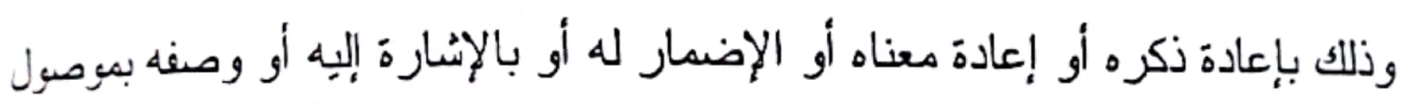

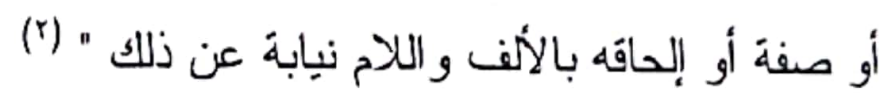

كما عرفها أيضا بأنها ". الإثارة إلى مذكور حقه أن بسبق ما بحيل إليه" (").

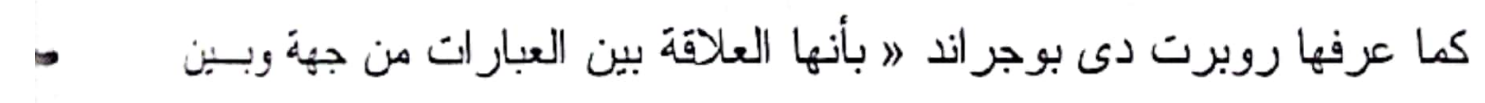
الأشياء والمو اقف في العالم الخارجى الذى تشير إليه العباراته|(أ).

$$
\begin{aligned}
& \text { (1) الجمهورية Yr مارس ه...T صY } \\
& \text { (r) البيان في روانع القر آن: صو (r) }
\end{aligned}
$$

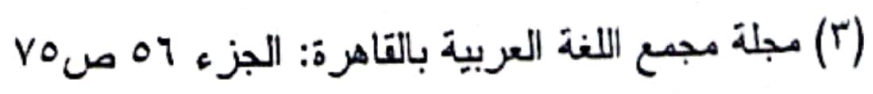

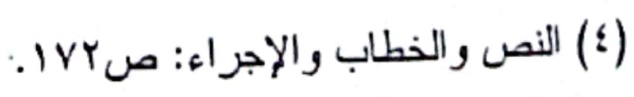




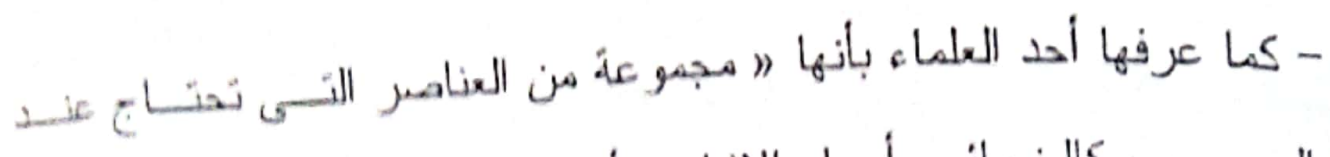

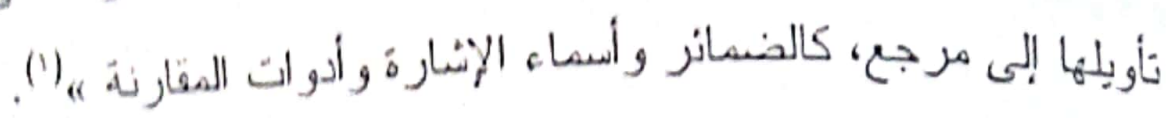
يتضح من التعريفات السابقة أن الأحالة عبارة عن عالقة نزبط بين مجنو عان من

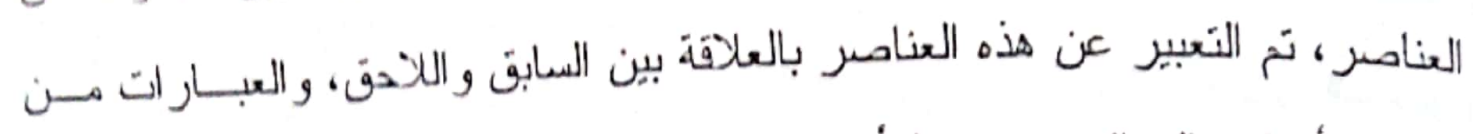
جهة و الأشباء و المو اقَّف من جهة أخرى.

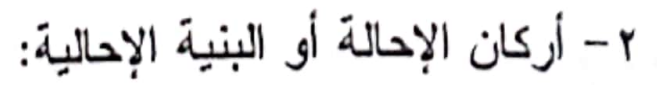
يمكن توضح أركان الإحالة في الشكل التالى: أركان الإحالة (البنية الإحالية)

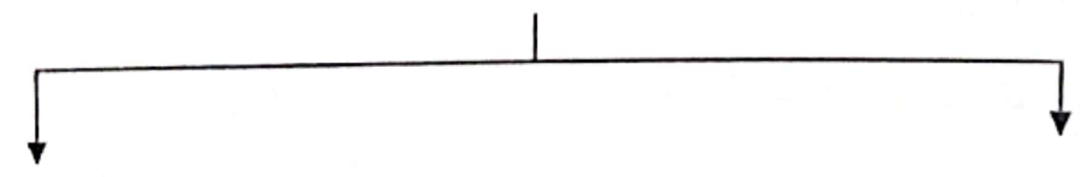 \\ العنصر اللاحق

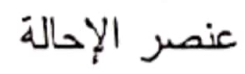 \\ صين الإحالة \\ الرو ابط الاحاليه

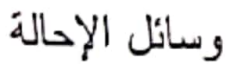 \\ العنصر السابن

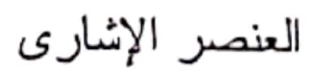

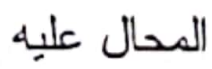

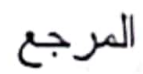 \\ المفنر \\ ذكرت في السكل السابق أركان الإحالة و المسميات المختلفة التى تطلق عليها،

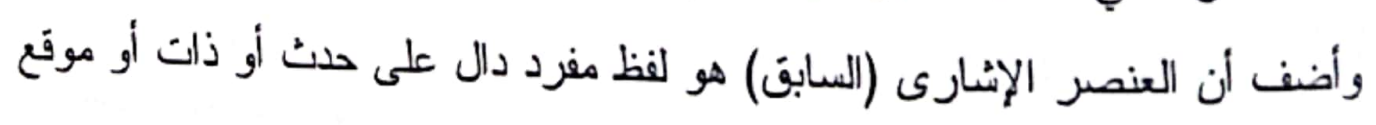

(1) د. عمر محمد أبو خرمة. نحو النص صץ^. 


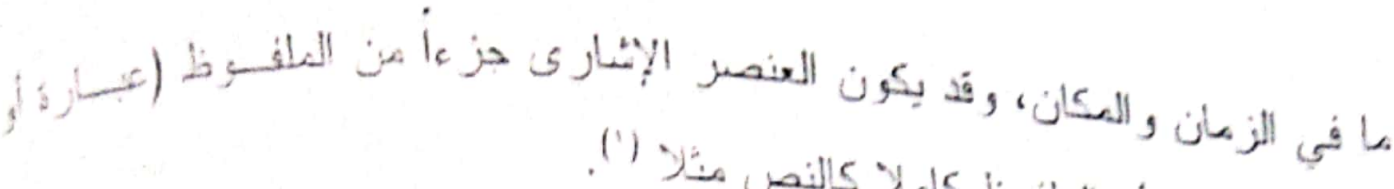

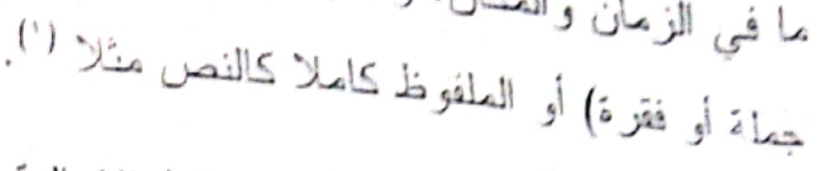

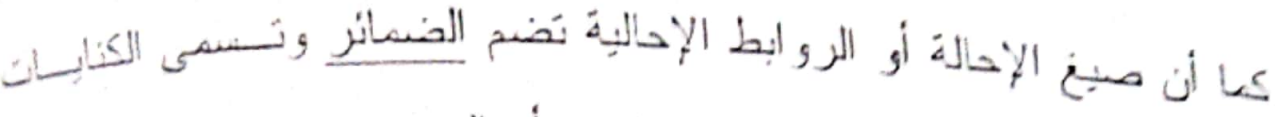

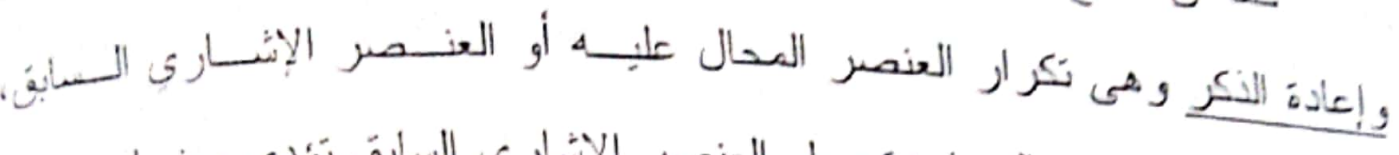

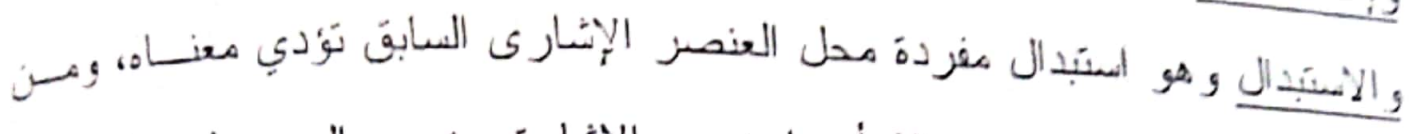

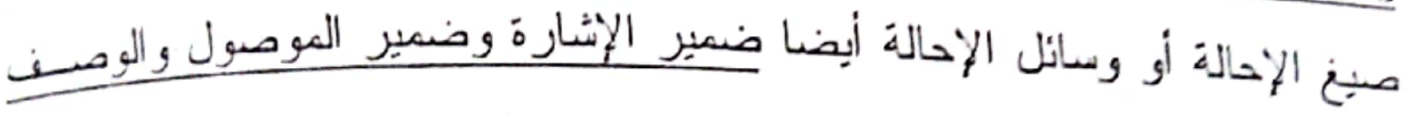

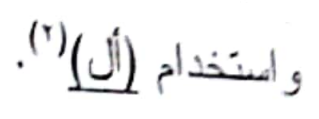

والدف أن الأصل في الإحالة أن تكون بنكر ار اللفظ، أى بنكر ار ذكر العصر

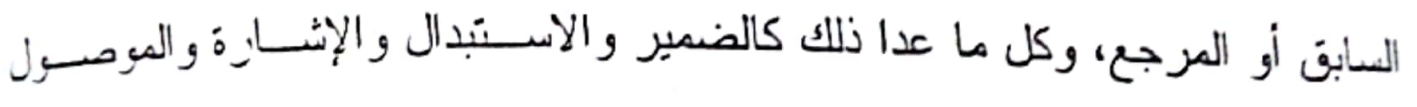
والوصف وأل، تعد كنابة أو بديلا عن إعادة الذكر ، و الواضح أن أكثر صيخ الإحالة

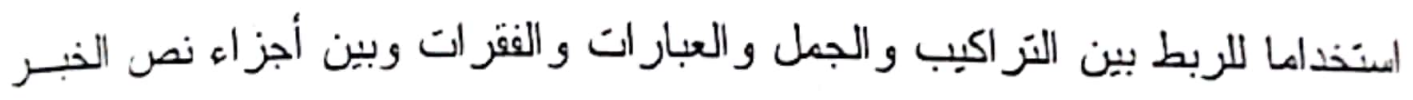
الصحفي كله هو الضمائر ، وإعادة الذكر أو نكرار العنصر الإثارى أو العرجع. وتتقسم الضمائر التى تستخدم كصيخ للاجحالة إلى: 1- ضمائر الثخص وتضم ضمائر النكلم و الخطاب والغيبة. r- ضمائر الإثارة نحو هذا - هذه- هذان - هاتًان - هؤلاء... وذلك وهناك وتلك و أوليك.....

r- ضمانر موصول كالذى و التى و الذين و اللان و اللتان....

(1) انظر الدكتور سعيد حسن بحيرى: دراسات لغوية تطبيتية ص10. (ץ) انظل روبرت دى بوجر اند: النص والخطاب والإجراء ص ا +r.

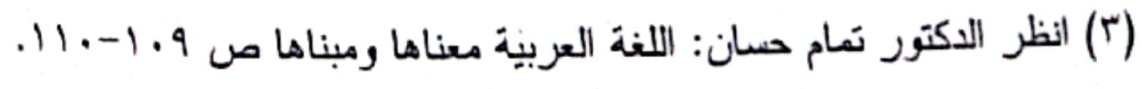




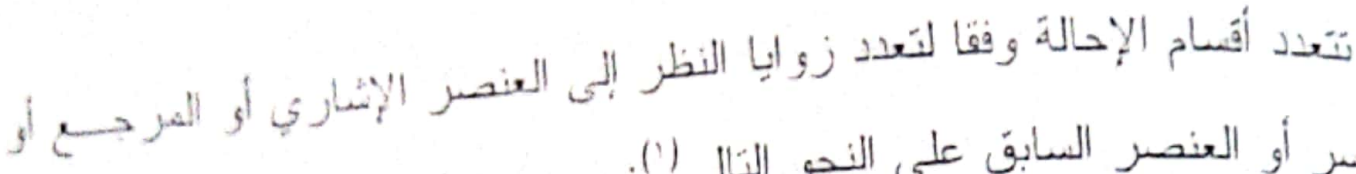
المفسر أو العنصر السابق على الندو النالي (1):

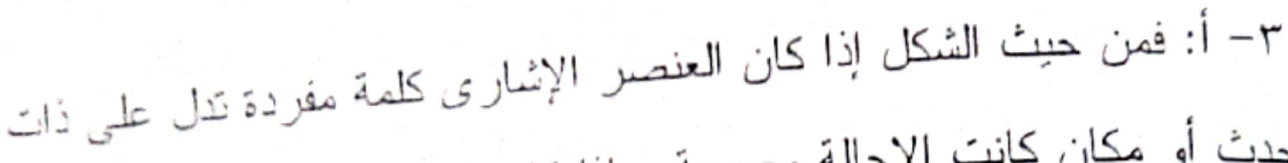

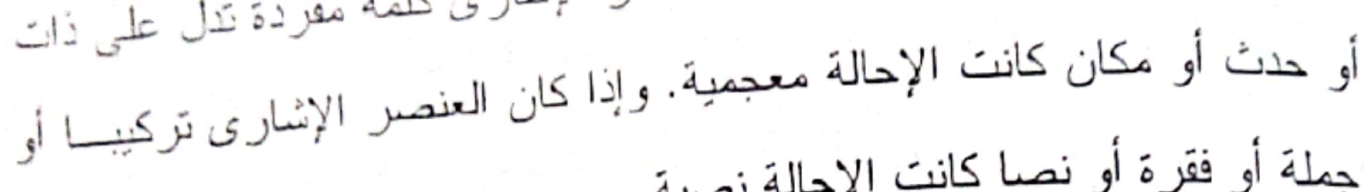
جملة أو فقرة أو نصا كانت الإحالة نصية.

r-ب: ومن حيث وجود العنصر الإشارى داخل النص أو خارجه: فإذا كان

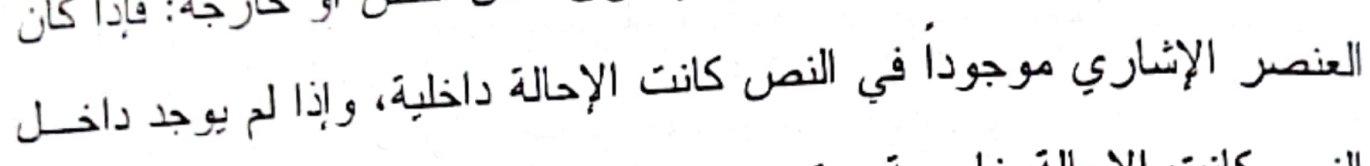

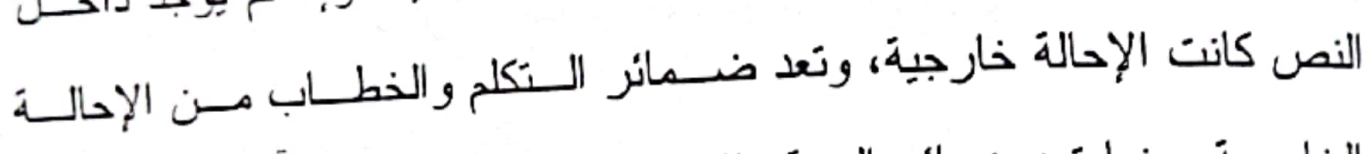
الخارجية، بينما تعد ضمائر الغيبة والإثارة و الموصول من الإحالة الاخلنية.

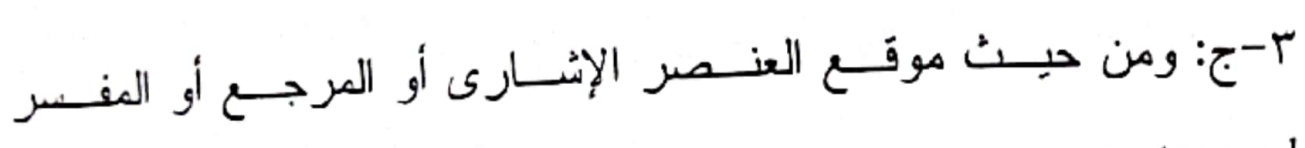
:antecendent

-فإذا كان متقدما على صيغ الإحالة (و هذا هو الأصل) كانت الإحالــة إلـي (Anaphora) متَّدم

وإذا كان العنصر الإثاري أو المرجع أو المفسر متأخرا عن صيغ الإحالــة

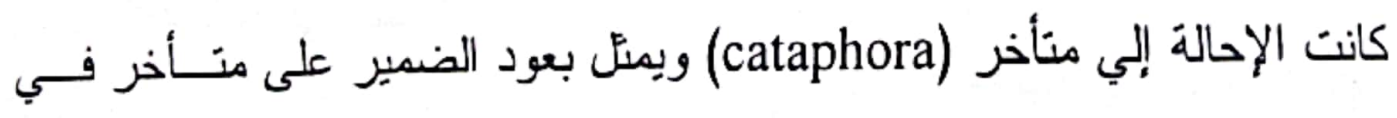
اللفظ و الرتبة الذي تحدث عنه النحاة العرب قديما r- د: وتتقسم الإحالة بحسب نوع الصيغ الزمنية، و العلامــات الإنــارية الزمنية التي بُشتمل عليها النص إلي (1) انظر الدكتور سعيد حسن بحيرى: دراسات لغوية تطبيقية ص AV-^9. 


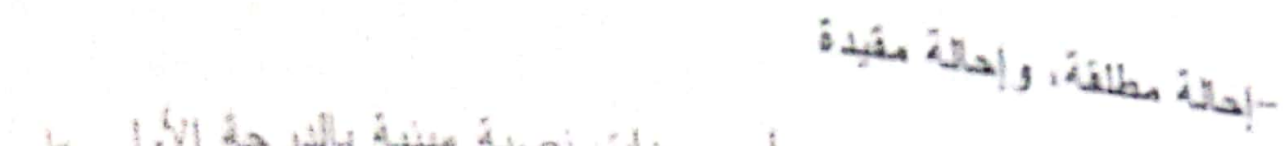

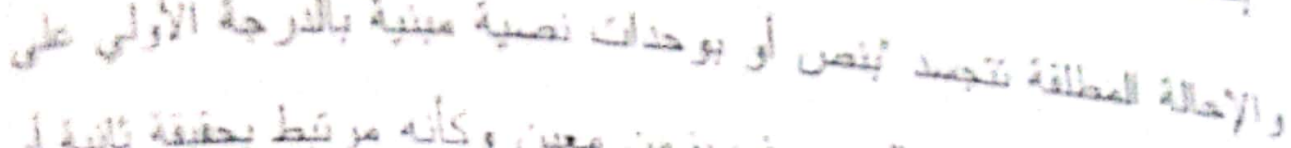

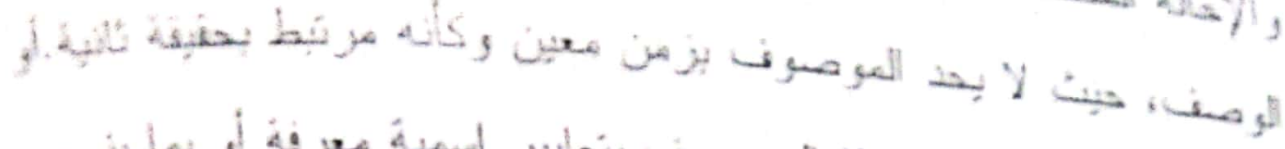

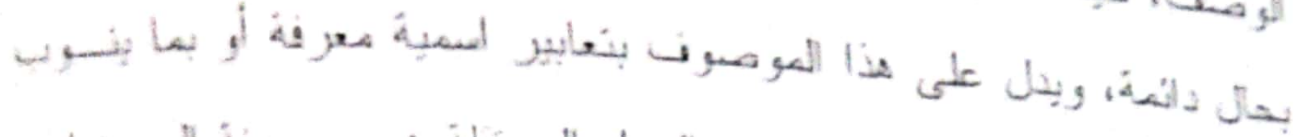

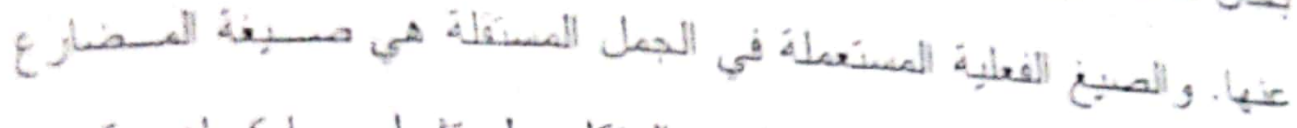

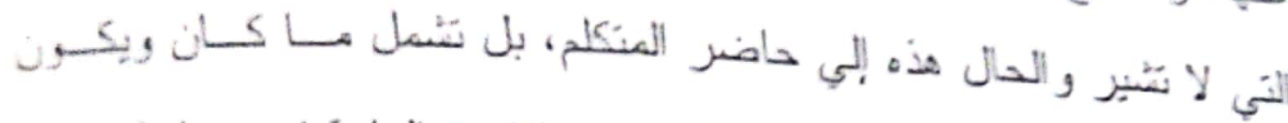

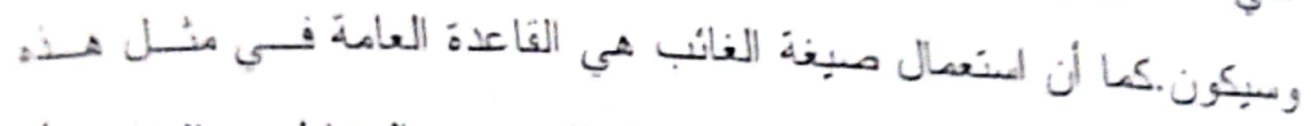

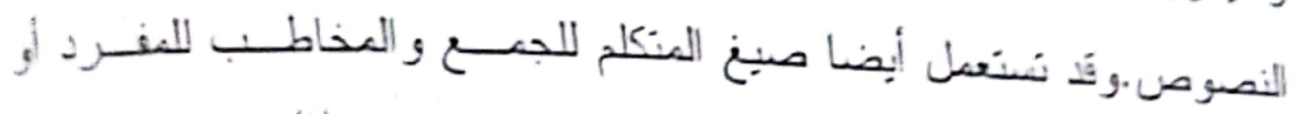

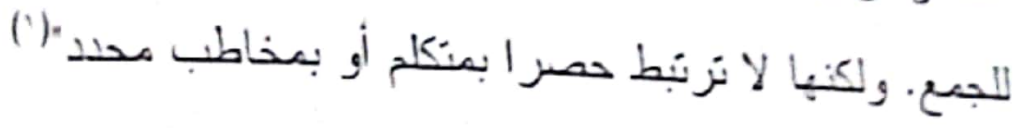
- موالإحلة المقيدة ذات جانبين: - الأول الإحالة العقبنة الإثارية - الثاني الإحالة المقيدة الإبشارية

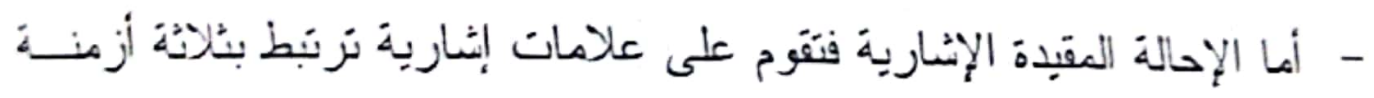
هي الحاضر و الماضى و المستقبل؛ والداضر هو دائما من الكلام أو منقاطع

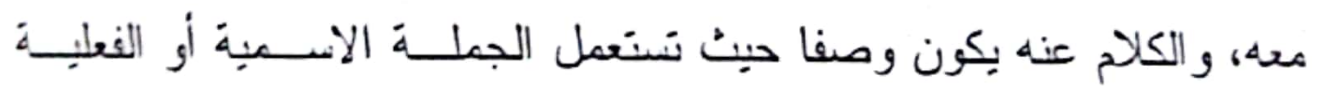

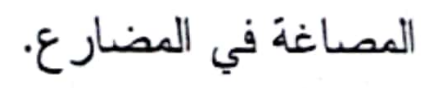

أما الماضى المعبر عنه في الإحالة الإشارية فيقاس بالمسافة التي تبعـده عـن

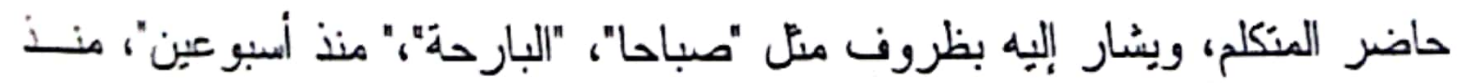
سنة تز افقه صيغ الماضى، ويكون الحديث عن هذا الماضى الإشاري وصفا وسردا معا. يقوم الوصف على اسنعمال جمل اسمية أو فعلية في صيغة المــضارع. وفـي

(1) مريم فرنسيس: في بناء النص ودلالته ص هץ. 


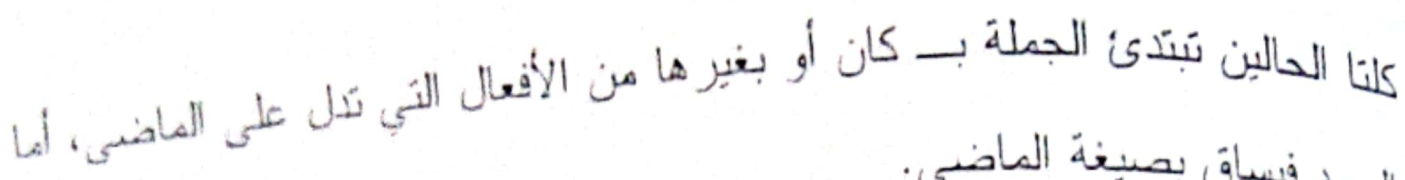

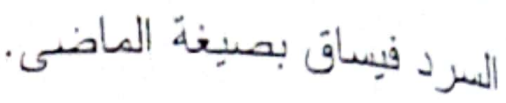

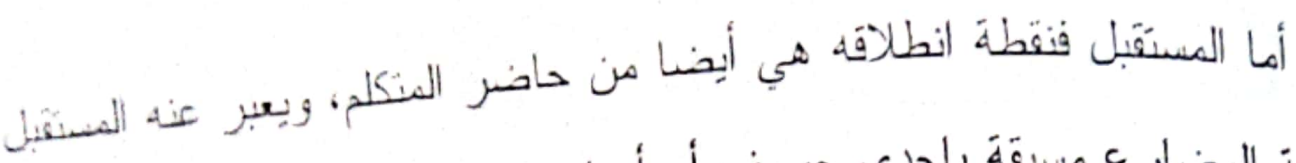

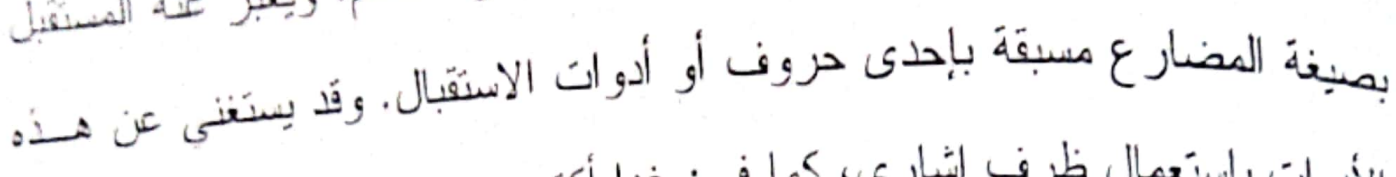

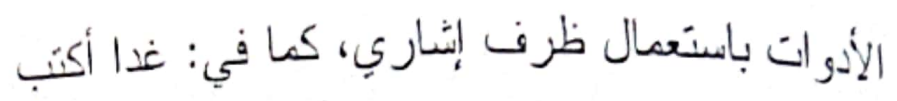

- أما الإحالة المقيدة الإثشارية: فهي سمة النصوص التي نحيل إلي ماض بيسند

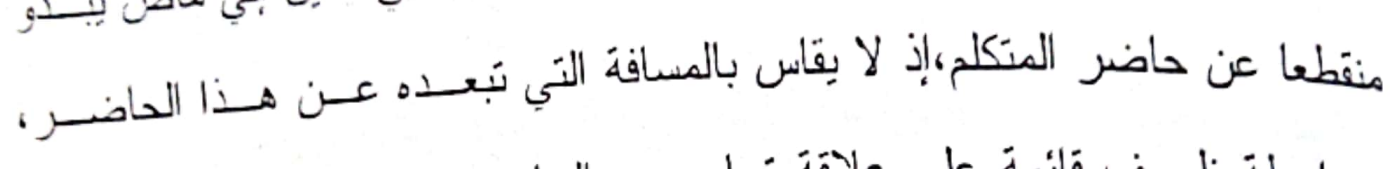

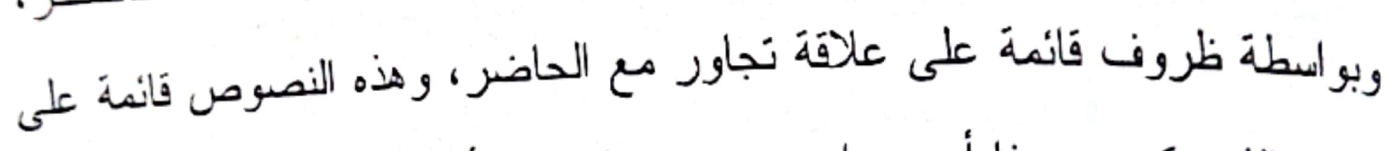
القص الذي بكون وصفا أو سردا، وبعبر عن الوصف أبضا.

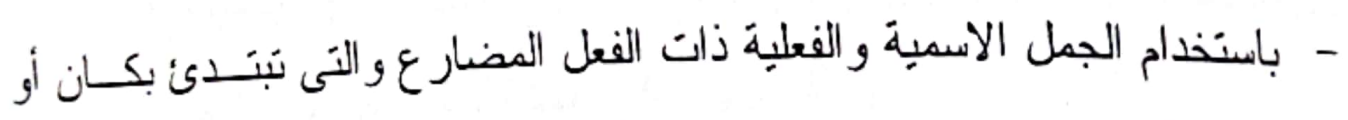

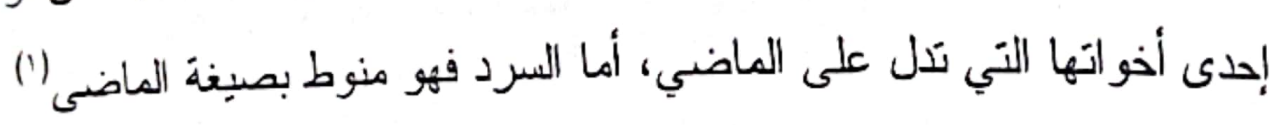
- نعود مرة أخرى إلي الحديث عن الربط بعد الانتهاء من الكلام عن الإحالة:

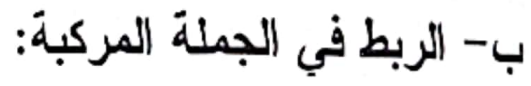

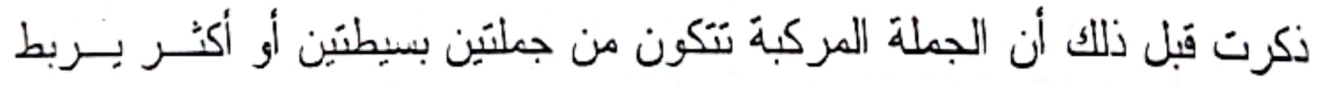
بينها بإحدى أنوات الربط العطفية أو الاستخر اكية

بلد أن الربط في الجملة المركبة في نص الخبر الصحفي تتعدد وسائله، ويمكـن

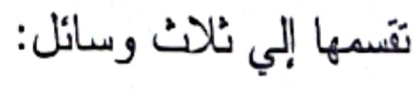
الوسيلة الأولي: الربط بالأداة الوسيلة الثاتية: الربط بالإحالة 


$$
\text { الوسيلة الثالثة: الربط بالأداة والآحالة }
$$

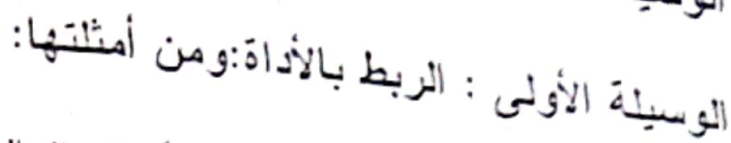

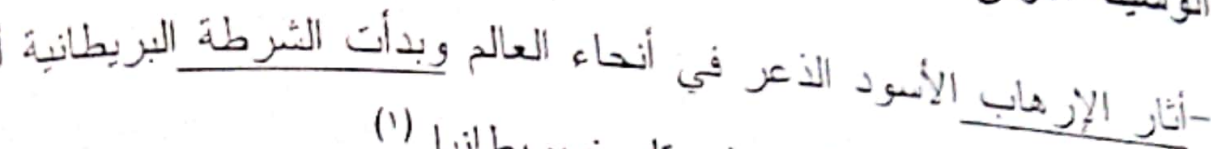

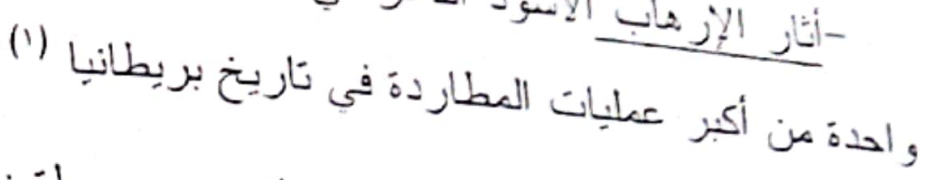

ربط حرف العطف (الواو) بين جملتهين بـسيطتين فعليتهين، الأولـي: أنسار

$$
\text { الإز هاب... و الثانية بدأت الثرطة البريطانية }
$$

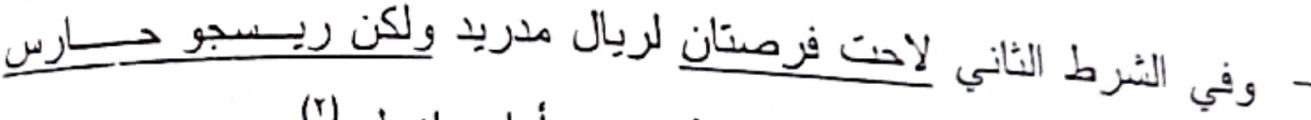

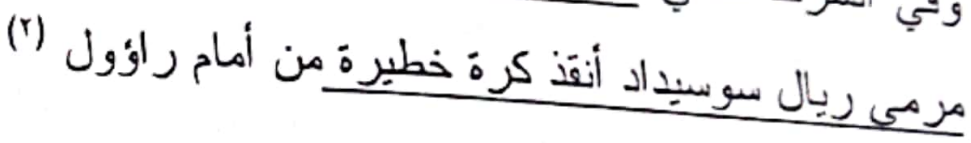

- ربطت (لكن) المثال السابق بين جملتين بسيطنين: الأولي جملة فعلبة (لاحت

$$
\text { فرصتان) و الثانية جملة اسمية (ريسجو ..أنقذ) }
$$

- قال لماذا هناك وزر اء ورؤساء وزر اء دوليون بزورون السلطة الفلـسطينبة ويلتقون هناك مع القِيادة الفلسطينية لِِس هذاك أي تحفظات بل على العكس

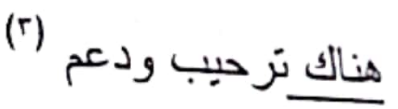

- ربطت (بل) في المثال السابق بين جملتين بسيطنين اسميتين الأولي (هنـاك أي تحفظات)، و الجملة الثانية (هناك ترحيب ودعم) في المنال

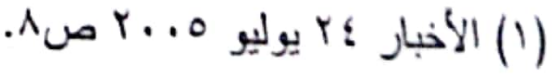

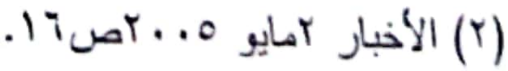

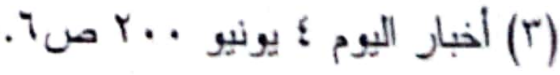




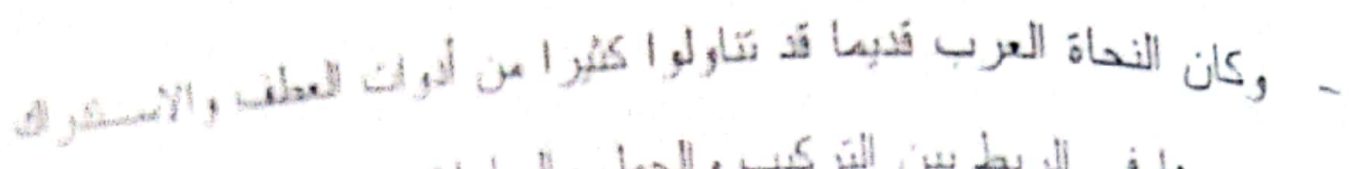

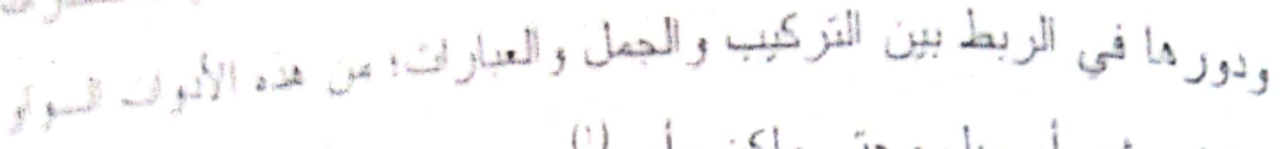

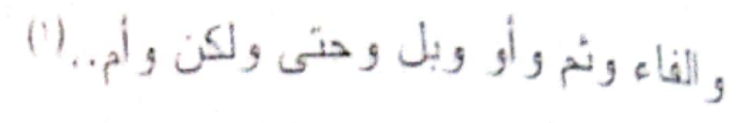

$$
\begin{aligned}
& \text { الوسئة الثانية الزبط بالإحالة: }
\end{aligned}
$$

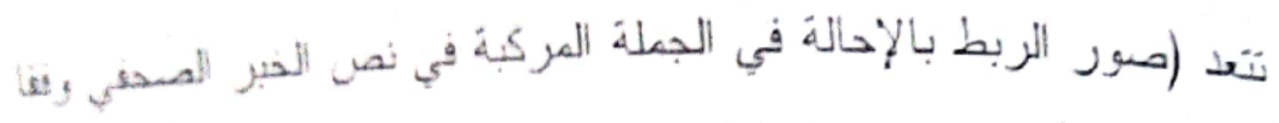

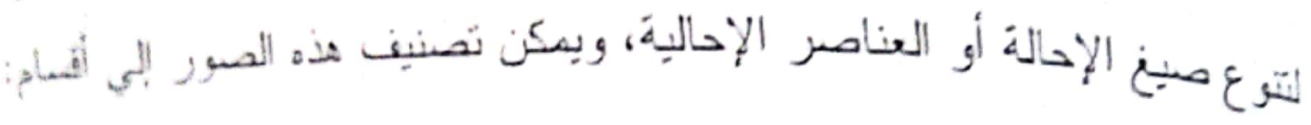

$$
\begin{aligned}
& \text { أ- اللزبط بالإحالة عن طريق الضمبر } \\
& \text { ب-الربط بالإحالة عن طريق إعادة الذكر } \\
& \text { ج- الربط بالإحالة عن طريق الضمير وإعادة الذكر معا } \\
& \text { د- الربط بالإحالة عن طريق الاستبدال } \\
& \text { ويمكن تقيم أمثلة للأقسام السابقة فيما يلي: } \\
& \text { أ- الربط بالإحالة عن طريق الضمير }
\end{aligned}
$$

يمئل الضميز هنا العنصر الاحالي أو صيغة الإحالة التي تحبـل إلـي

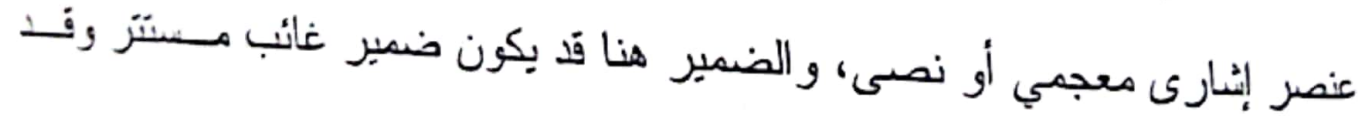

$$
\text { بكون ضمبر إبـارة (هذا - هذه - هؤلاء - ذلك - تلك...) }
$$

فمن أملية الإحالة بضمير الغائب المستر :

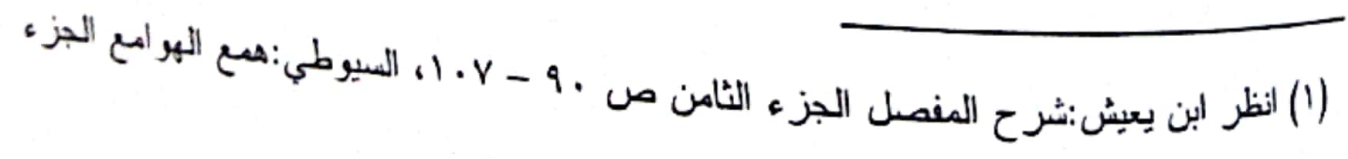

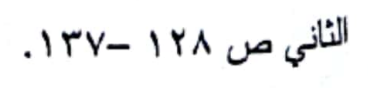

$$
1.0
$$




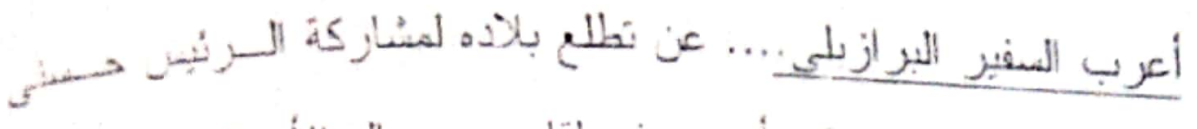

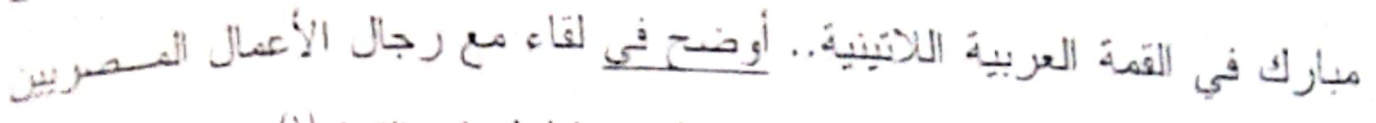

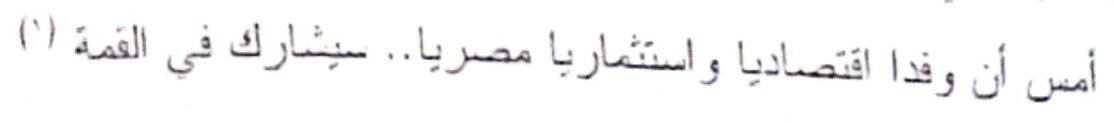

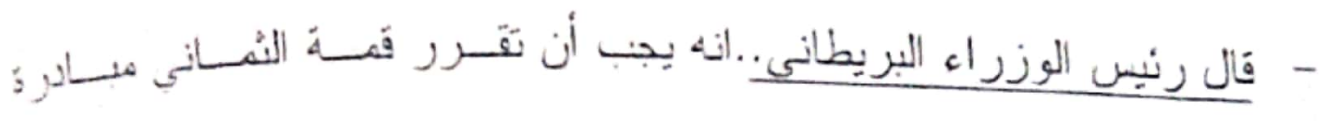

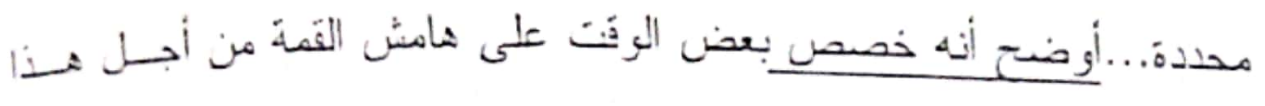

$$
\begin{aligned}
& \text { الغرض(") }
\end{aligned}
$$

في المثال الأول تكونت الجملة المركبة من: الجملة الأولي جملة فعلية الجملة الثانية جملة فعلية

$$
\text { أعرب السفير البرازيلي أوضح... أن وفدا اقتصاديا }
$$

تكألف البنية الإحالية في الجملة السابقة من:

$$
\text { العنصر الإثاري أو المرجع أو المفسر + صبغة الإحالة }
$$

الضعير المسترَ في الفعل

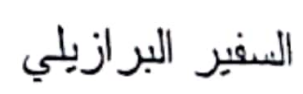

$$
\text { أوضح (هو) }
$$

وفي المثال الثاني نكونت الجملة المركبة من.

الجملة الثانية جملة فعلية

الجملة الأولى جملة فعلية

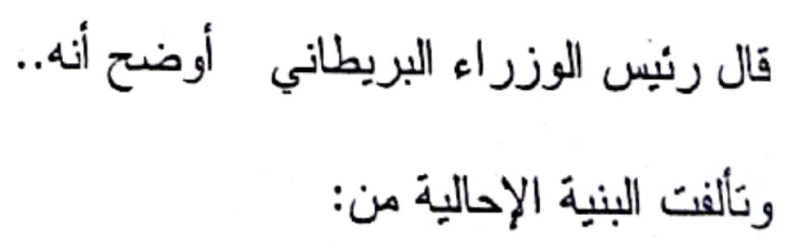

$$
\begin{aligned}
& \text { (1) الجمهورية Yr مارس ... Y صI. }
\end{aligned}
$$

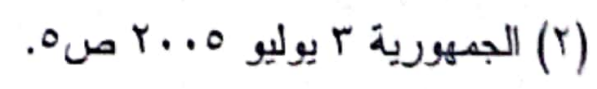




$$
\begin{aligned}
& \text { العنصر الإنشاري أو المرجع أو المفر + صبغة الإحالة }
\end{aligned}
$$

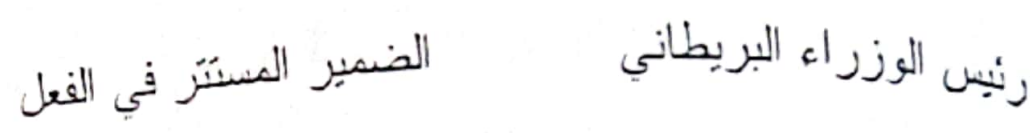

$$
\begin{aligned}
& \text { أوضح (ه) }
\end{aligned}
$$

والملاحظ أن العنصر الإنشاري أو المرجع الثنملت عليه الجملة الأولي من

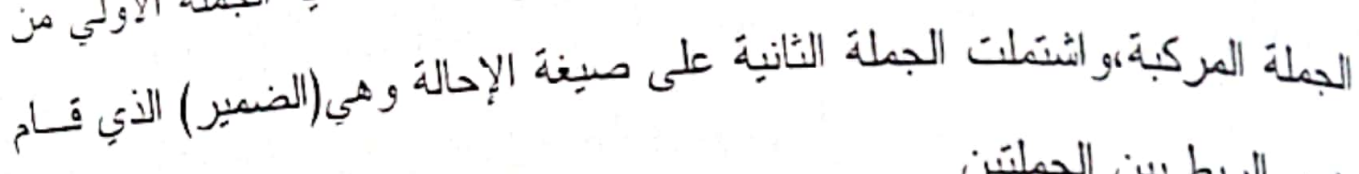
بكور الربط بين الجملتبنِ كما نلاحظ كذلك أن الإحالة في المثالين إحالة منقّمة جاعت وفقا للأصل؛ بمنى تقدم المرجع أو المفسر وتأخر الضمبر أو عنصر الإحالة. ويضضح أيضا أن الإحالة في المثالين إحالة معجمبة؛ فالمرجع أو العنسمر

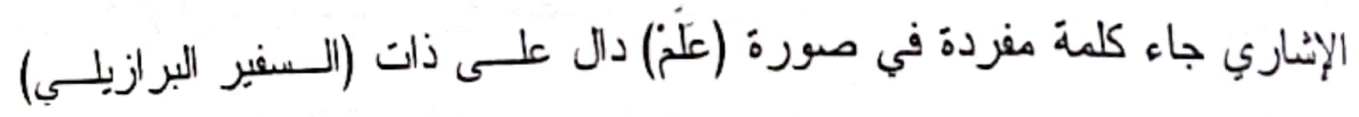

$$
\text { و(رئيس الوزراء البريطاني) }
$$

- وفي نص الخبر الصحفي كثير ماتقَدم العنصر الإحالي الذي بــرد فـــي صـسورة الضمبر على المرجع أو العنصر الإشاري ومن أمتلنه:

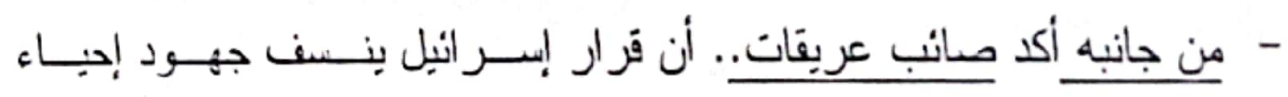

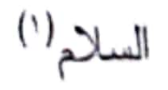

- ومن جهيَه أعرب الرينبس الأسر ائبلى عن سعادته (") - ومن أمثلة ضمير الإثتارة:

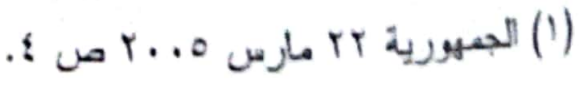

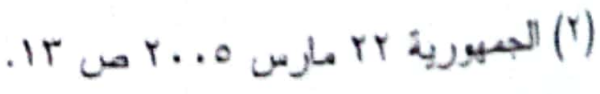




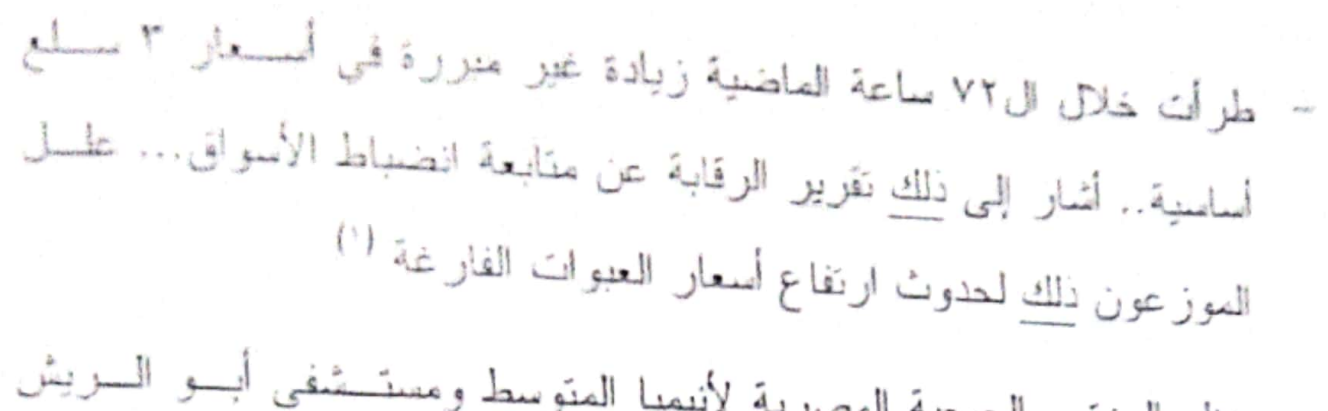

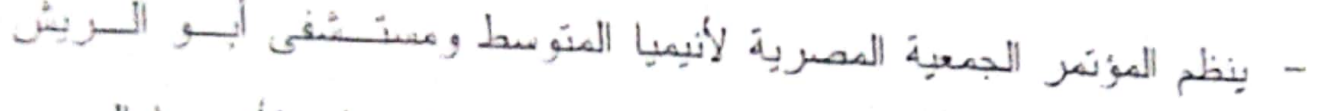

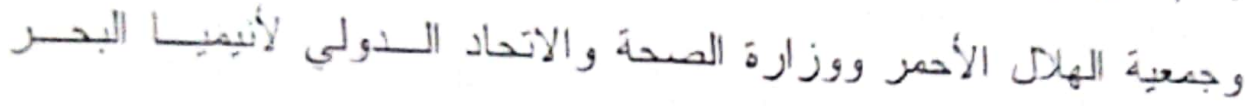

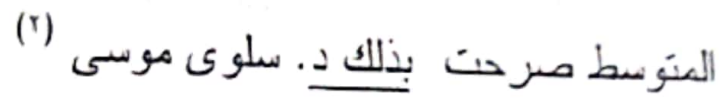

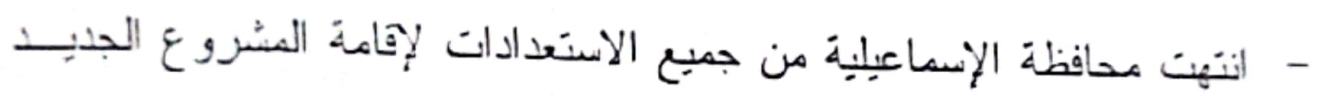

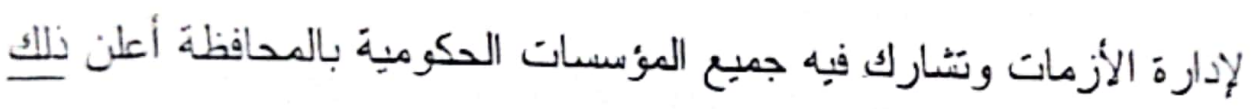

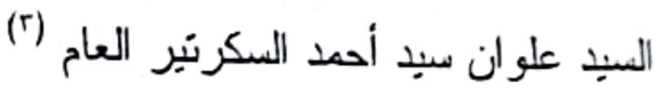

- وهي بداية جيدة لفريق مجدد تم تحويل سيناريو المباراة على أرضـه مسن

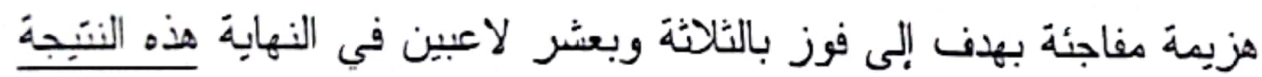

جيدة (؛) مزئة

- في الأمتلة السابقة سُتَّل الجملة المركبة على جملتين:

- الجملة الأولى تمثل عناصرها كلها العنصر الإثاري أو المرجع أو المفر ،

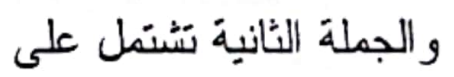

ضمير الإنشارة (ذلك أو هذه أو غيرهما) الذي يقوم بدور الرابط بين الجملتِن.

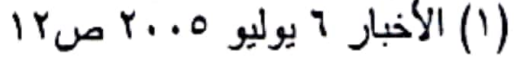

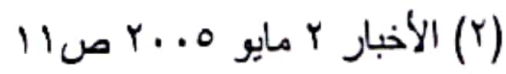

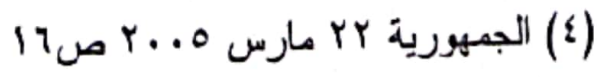



بحبل إلى ملفوظ كامل

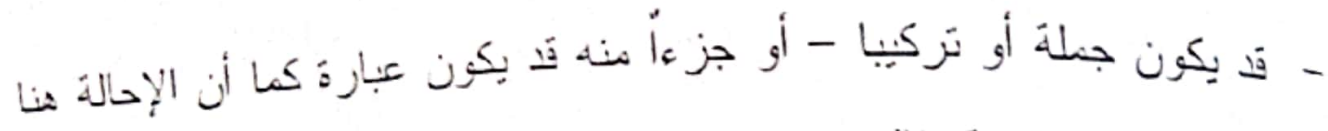

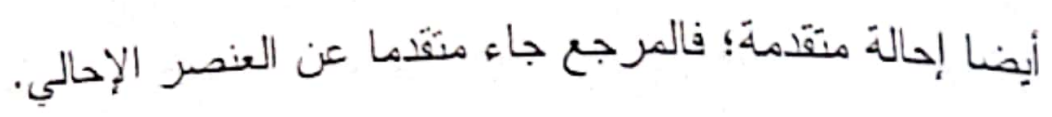

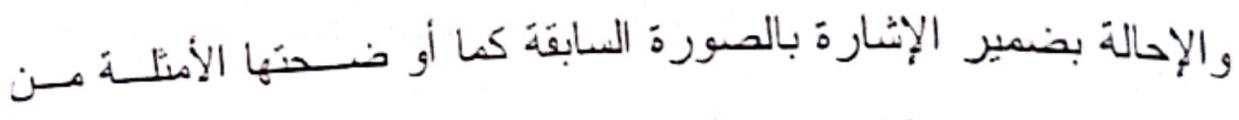

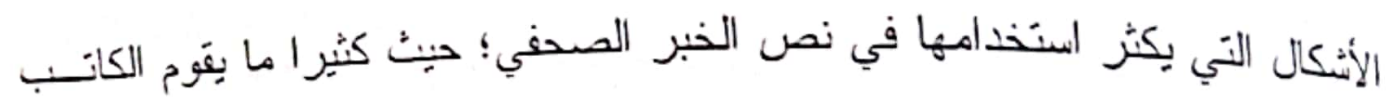

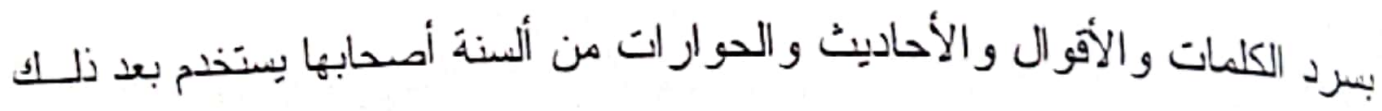

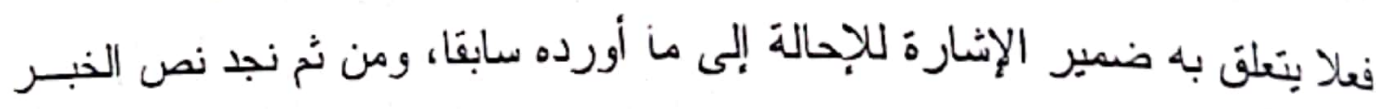

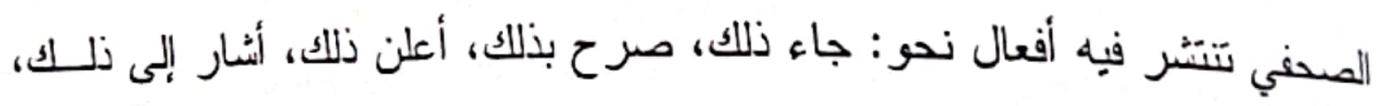
قال إن ذلك.... إلخ

والحقبقة أن ضمير الإشارة بمختف أنشكاله الواردة فــي نــص الذبـر الصحفي بصورته السالفة الذكر لا يؤدي دور الربط فقط بين أجزاء الجملة المركبـة

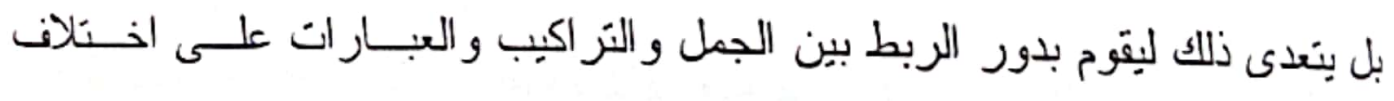

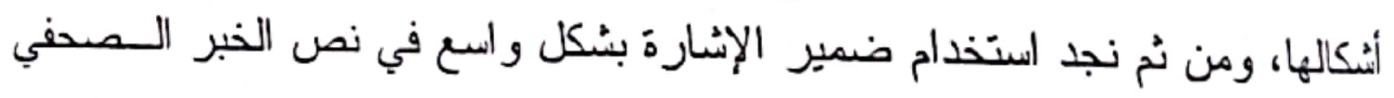

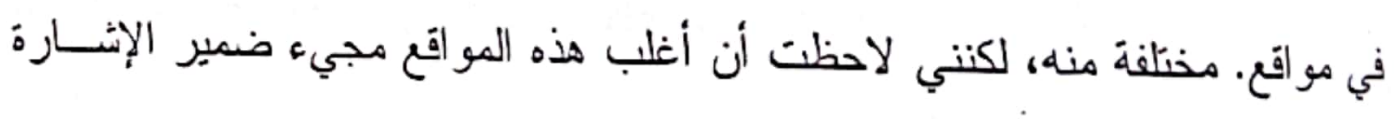

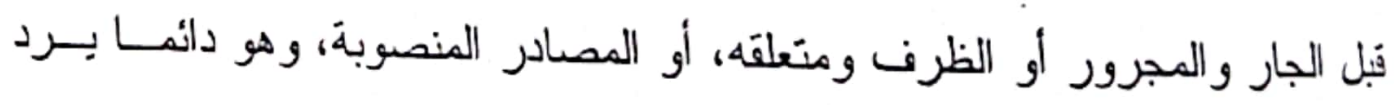

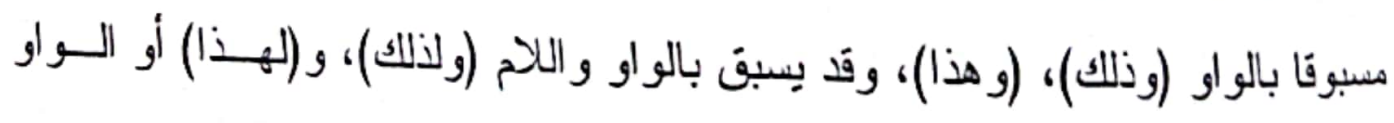
و الباء (وبنلك)...

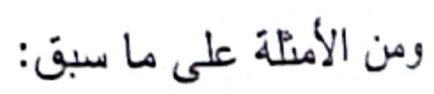




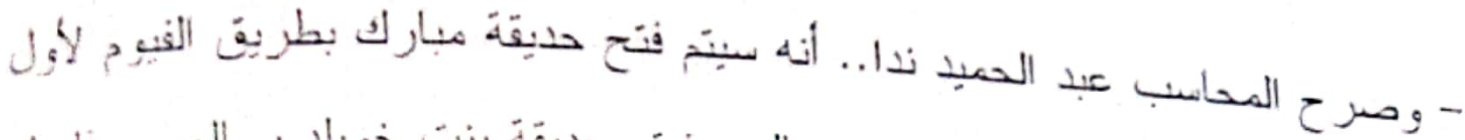

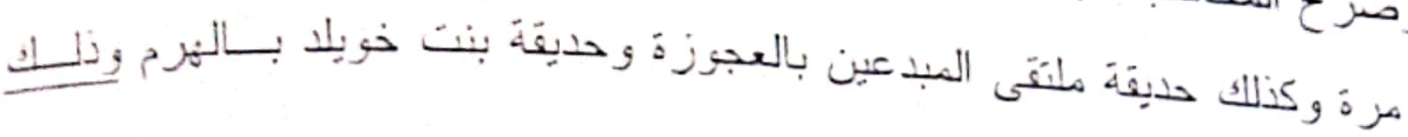

(1) مجانا للجمهيور وكلة

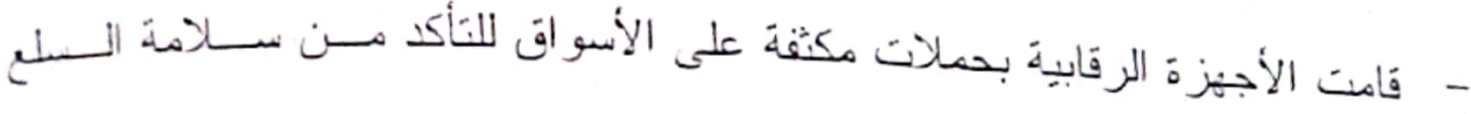

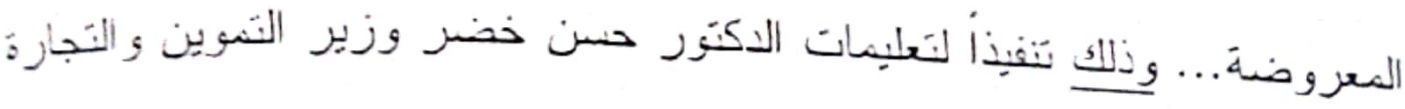

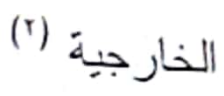

- يؤدي لاعبو حرس الحدود وطلاثع الجيُ لكرة القَم العمة كمكافأة أولية إلـى

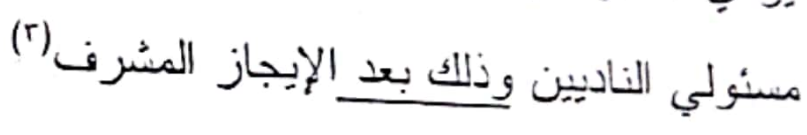

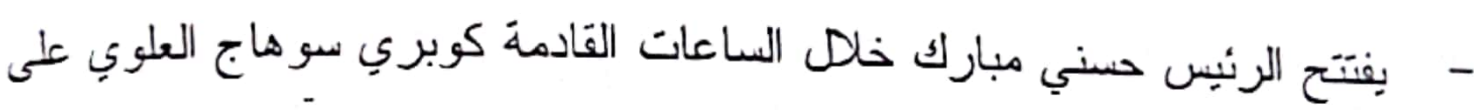

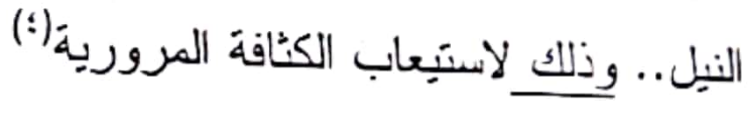

- مدق الرئيس حسني مبارك أمس على أربعة قو انين في إطار الإصلاح السباسي

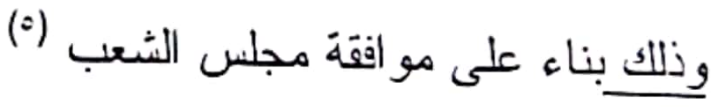
ب- الربط بالإحالة عن طريق إعادة الذكر وله صورتان: ب- ا : إعادة ذكر العنصر الإشاري كله ومن أمتلنه:

$$
\begin{aligned}
& \text { (1) الأخبار Y مايو r..0 صr }
\end{aligned}
$$

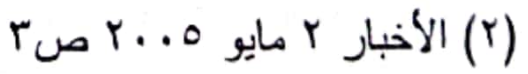

$$
\begin{aligned}
& \text { (r) الأخبار r مايو ص } 10
\end{aligned}
$$

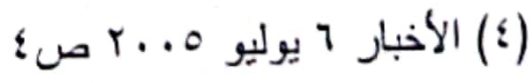

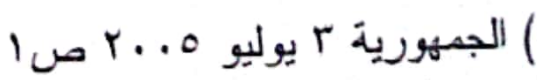


- اندلع دريق هائل بعد ظهر أمس بصصنع احنية كبير من طانقين بنز الكتاب

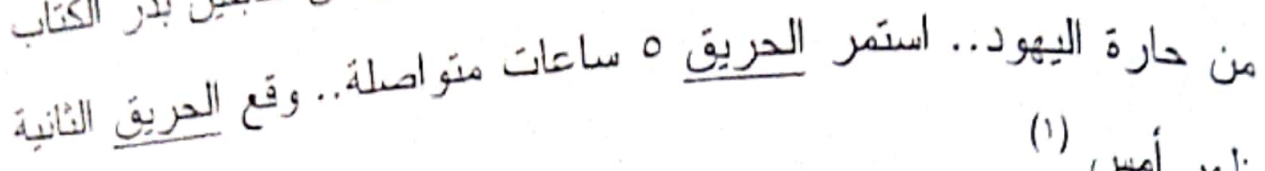

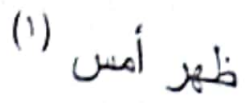

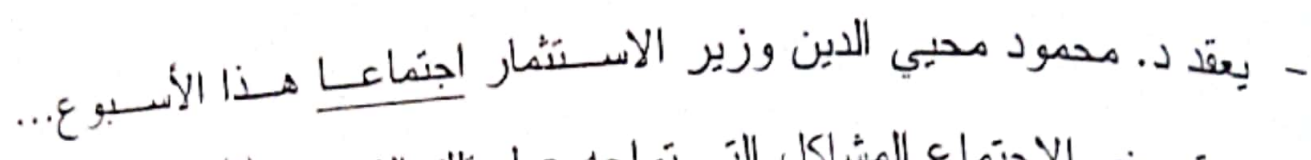

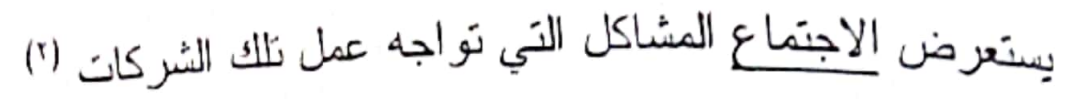

- في المثال الأول تتكون الجملة المركبة من ثُلاتث جمل فعلية هي: الجملة الثالثة

الجملة الثاتية

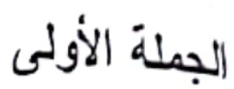

وقع الحريف

استمر الحريق

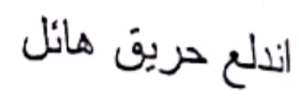

- ت تألف البنية الإحالية من:

العنصر الإشاري (المرجع) العنصر الإحالي

كلمة حريق في الجملة الأولى وهي هو إعادة ذكر العنصر

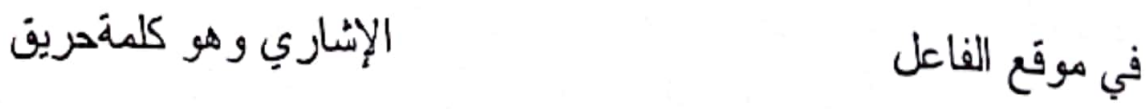

في الجملة الثانبة والثالثة

ووردت في موفع الفاعل

- في المئال الثاني تتكون الجملة المركبة من جملتين فعليَّن هما: الجملة الثاتية

الجملة الأولى

بستعرض الاجنماع

بعتد د. محمود مديب الدين اجتماعا

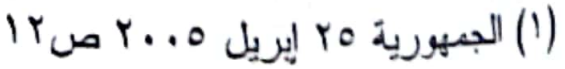

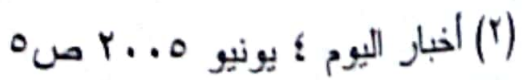




$$
\begin{aligned}
& \text { - } \\
& \text { إنسا }
\end{aligned}
$$

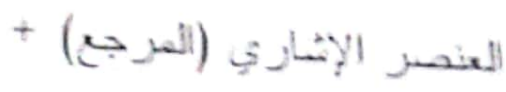

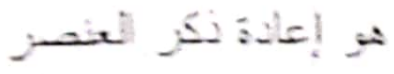

$$
\begin{aligned}
& \text { كلسة اجنساعت في الجملة الأولى }
\end{aligned}
$$

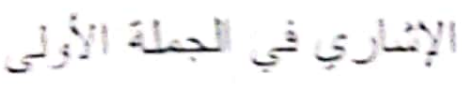

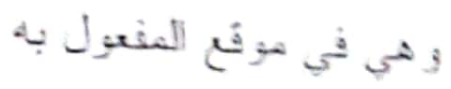

$$
\begin{aligned}
& \text { وهز كلة (الاجنَاساع) }
\end{aligned}
$$

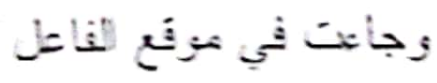

$$
\begin{aligned}
& \text { في الجندة التبنة } \\
& \text { ب-r إعادة نكر جزء من العنصر الإثاري، ومن أنتئ }
\end{aligned}
$$

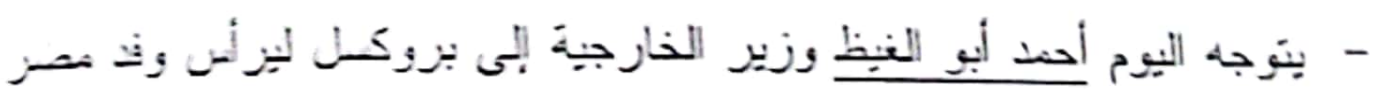

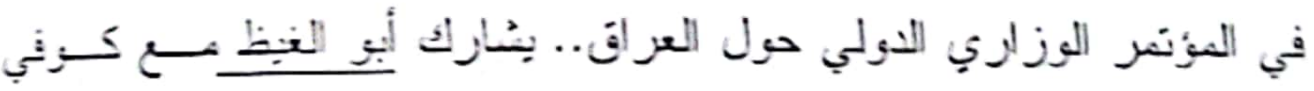

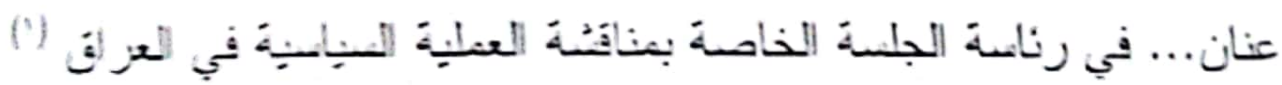
- أعلن فاروف حسني وزيز المثافية أن البعنة المصرية الأمانية عثرت طـى

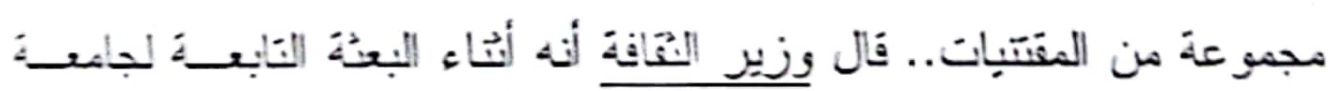

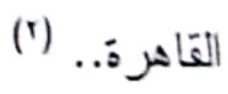

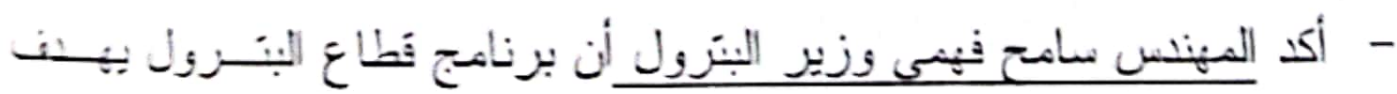

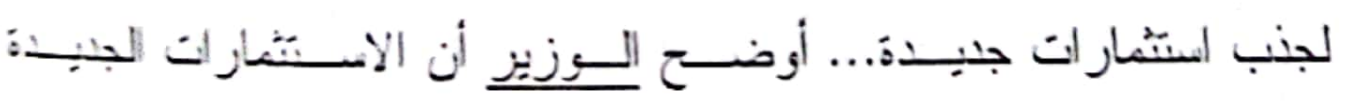

$$
\text { (r) }
$$

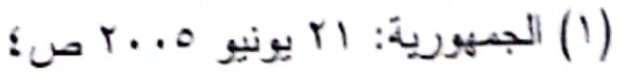

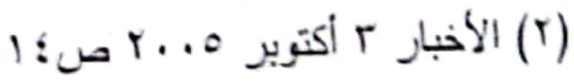

$$
\begin{aligned}
& \text { (r) الجمهورية } 19 \text { أضسطس O. . r صـى }
\end{aligned}
$$




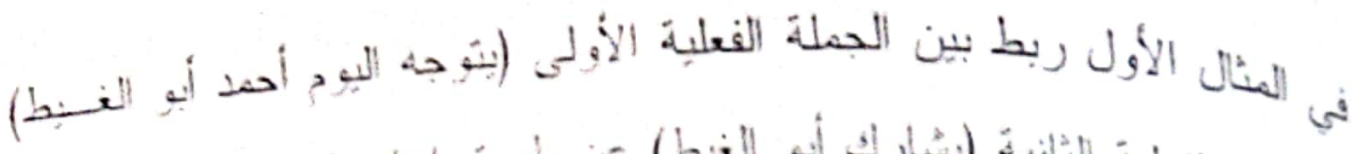

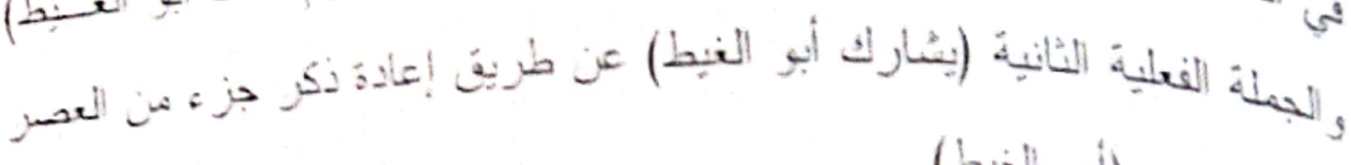

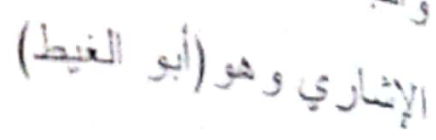

في المبلة الثانية الذي بمثل العنصر الأحلى

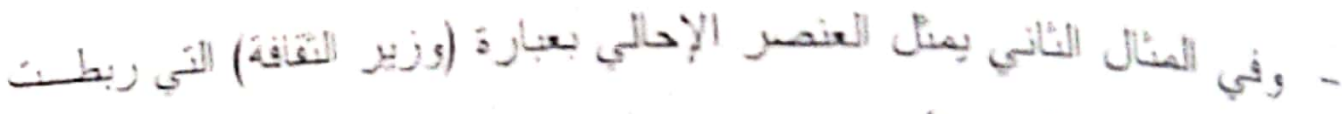

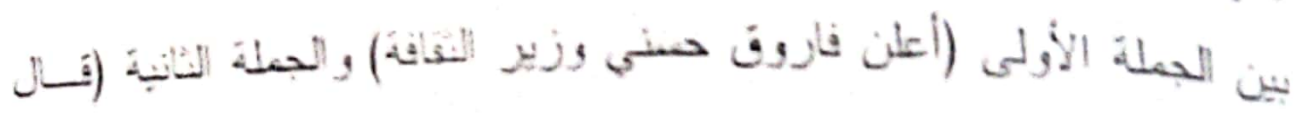

وزيز

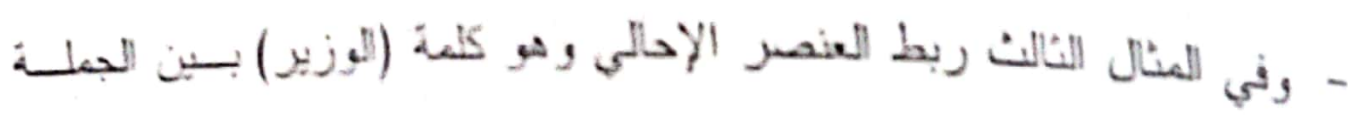

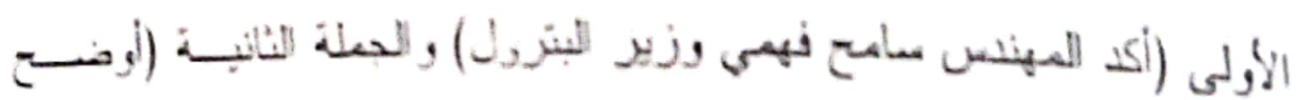

$$
\text { الوزير) }
$$

ج- الربط بالإحالة عن طريث الضمير وإعادة لأكر معا، ومن أمثلته: -

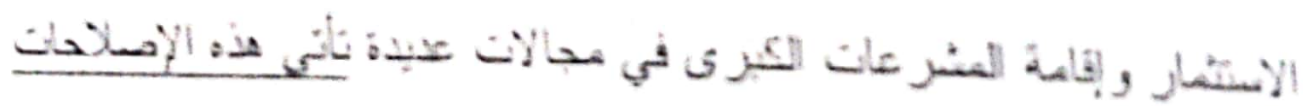

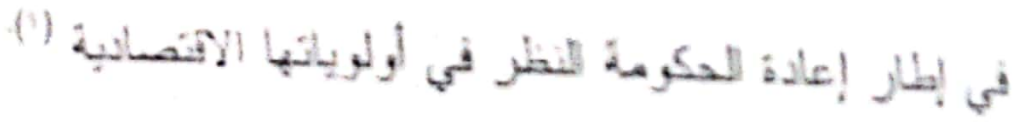

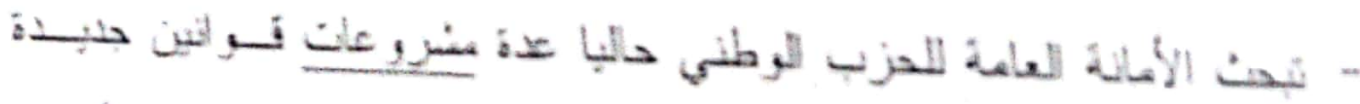

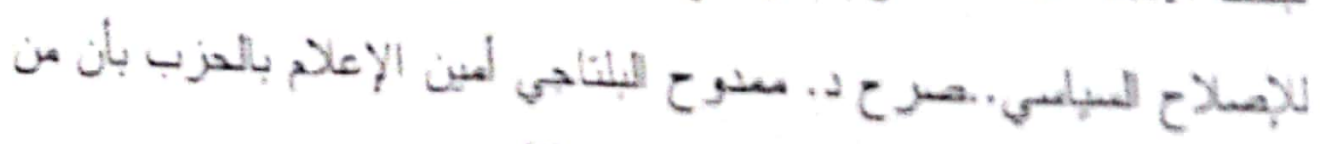

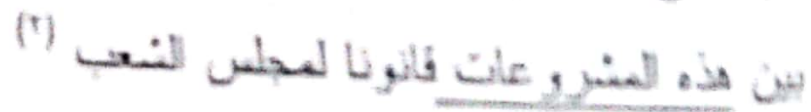
" 


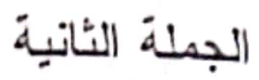

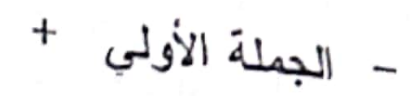

$$
\text { - تشهيد سوريا حاليا مرحلة من تأتي هذه الإصلاحات }
$$

$$
\text { والعنكون البنية الإحالية في الجملة المزكية السنقة من: }
$$$$
\text { هو كلمة الإصلاحات التي جاءت هو ضمير الإشارة (هذه). }
$$

في مكملات الجملة الأولي اعادة ذكر العنصر الإنشاري وهو

كلمة (الإصلاحات) في الجملة الثانبسة،

$$
\text { وجاء }
$$

الضمير والعنصر الإثشاري المكرر في

هوقع الفاعل من هذه الجملة

في المنال الثاني تكونت الجمل المركبة من جملتين فعليتِين

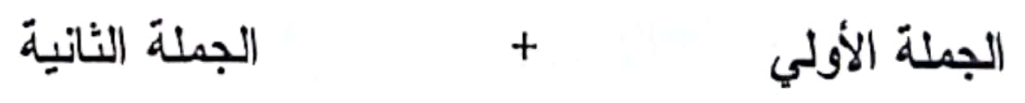
تبحث الأمانة العامة للحزب صرح د. ممدوح البلتاجي..بأن من

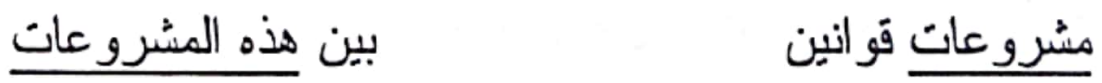
وجاهت البنية الإحالية في الجملة المركبة السابقة في البُّكل التالي:

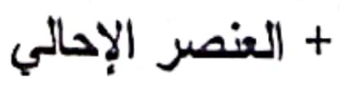

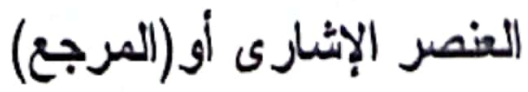
هو ضمير الإشارن(هذه)

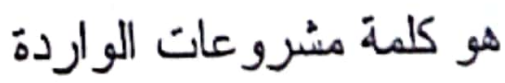


في موقع المفعول في الجملة الأولي العنصر الأناري المكرر

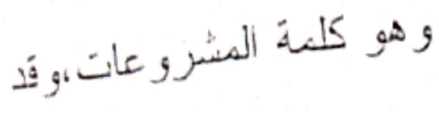

جاء الضنمبر و العنصر الأندار بي

المكرز في مكونات المزكبب غبر

المسنقّل الوارد في موقع المفعول به

للفعل صرح المنتعِي بحرن الجر

لـ الربط عن طريق الاستبدال، ومن أمتلته:

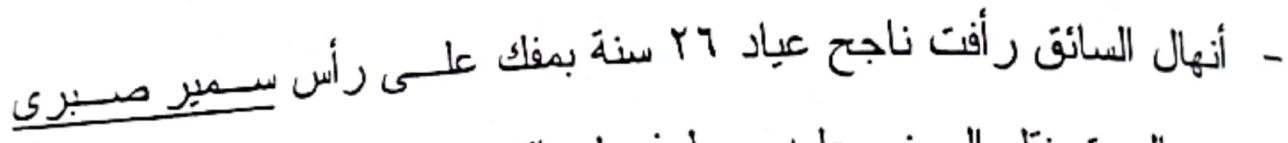
غربال.تمت نقل المجنى عليه وسط ذهول باقي اللاعبين و المارة) - انتهت أعمال التدريب الجوى المصرى السعودي المنشترك (فيصل 1 استمر التفيذ بأسابيع نفذ الجانبان خلاها طلعات قتال (') - في المثال الاول استبل العنصر الإشاري في الجملة الأولي وهــو (سـمبر صبرى غربال) بعبارة (المجنى عليه)التي نمنل العنصر الإحالي في الجملة الثانية

- في المنال الثاني استبدل العنصر الإشاري في الجملة الأولي وهو (المصري السعودى) بكلمة (الجانبان)التي تمثل العنصر الإحالي في الجملة الثانية.

- الوسيلة الثالثة الربط بالأداة و الاحالة:

$$
\begin{aligned}
& \text { (') الجهورية r r مارس ه... }
\end{aligned}
$$

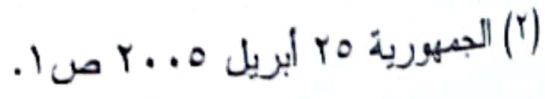




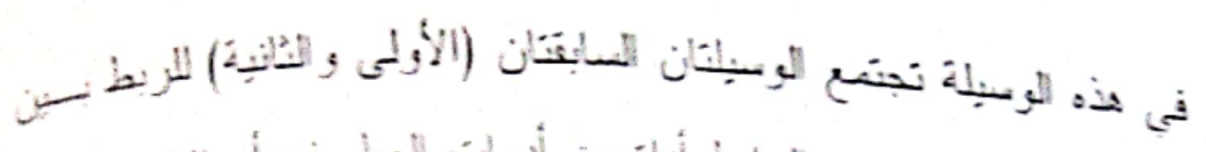

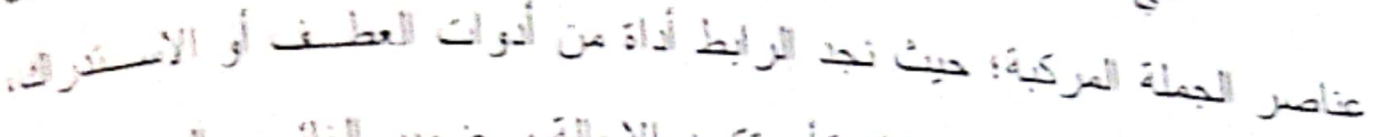

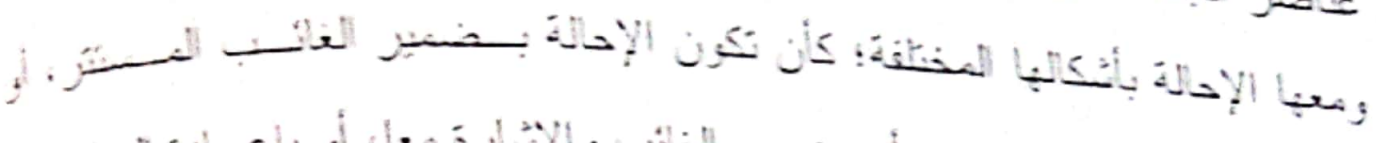

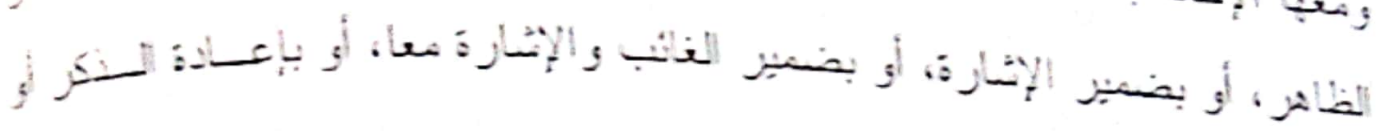

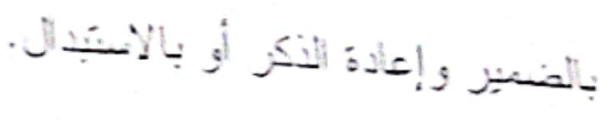

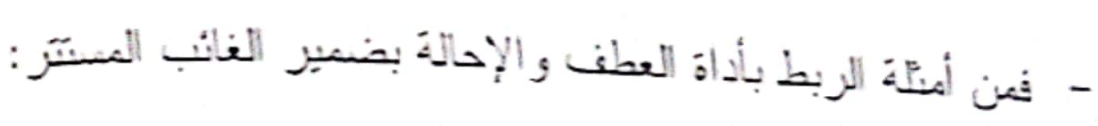

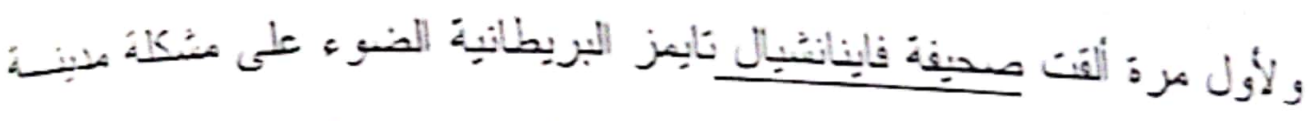

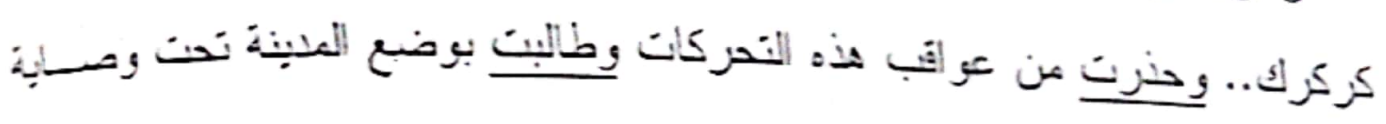

(1) الأمم المنحدة:

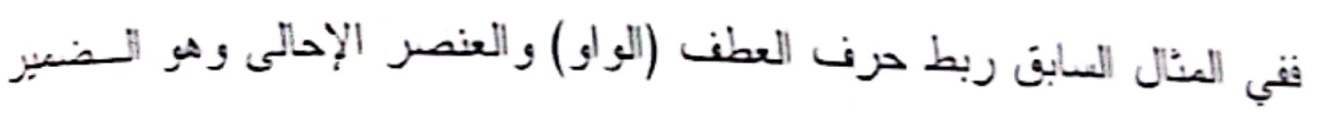

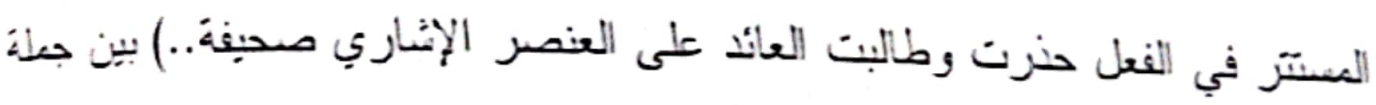

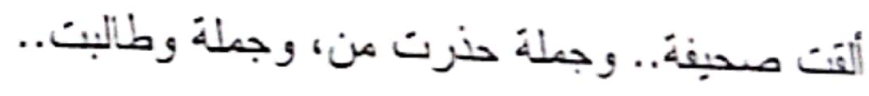

ومن أمتلة الربط بأداة العطف والإحالة بضمير الغائب الظلهز :

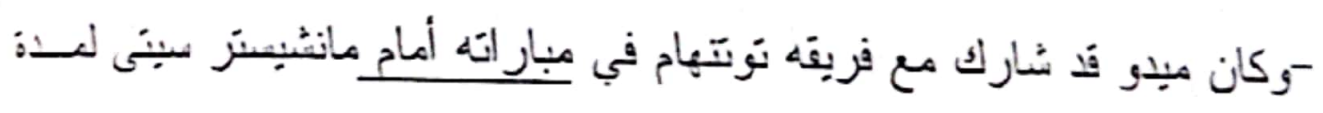

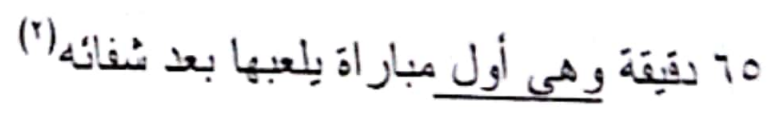

في العثال السابق قام حرن العطف (الواو) والإحالة بضمبر الغائب (ثي) وهن

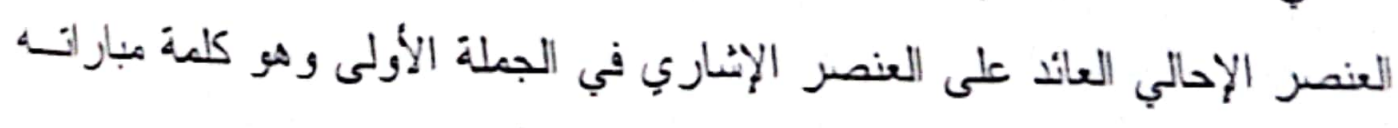
بالربط بين جملة وكان ميدو قد شارك..وجملة وهي أول مبار اة..

ومن أمنلة الربط باداة العطف وضمير الإثنارة:

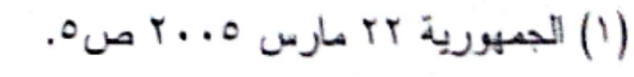

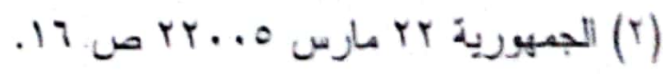




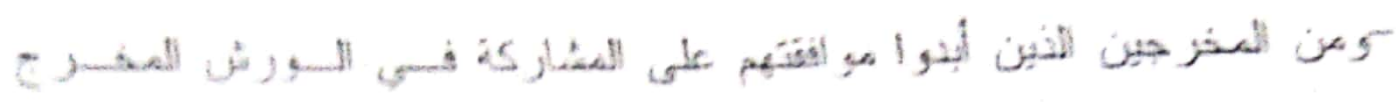

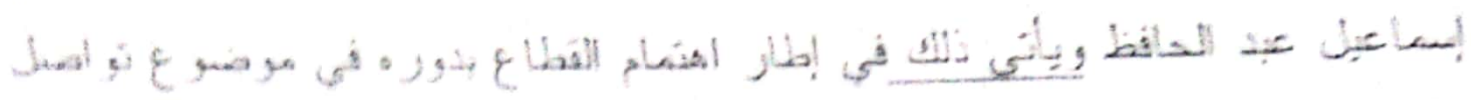

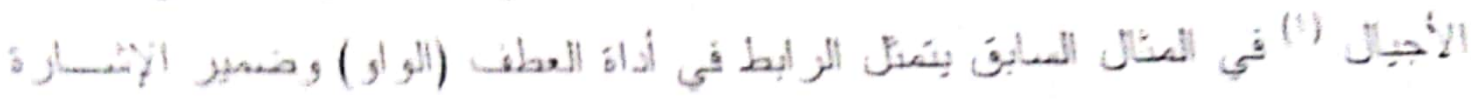

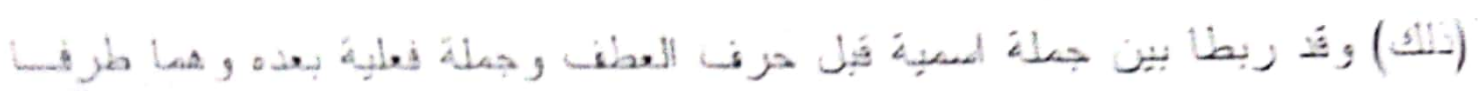
الجندة المزكبة.

$$
\text { ومنال آخز للزبط النسابق: }
$$

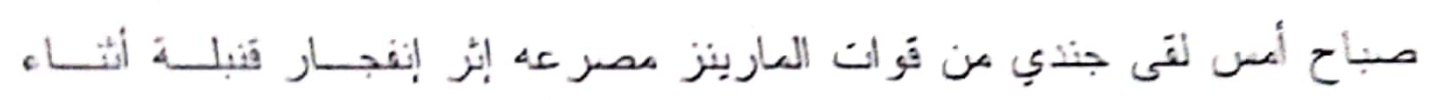

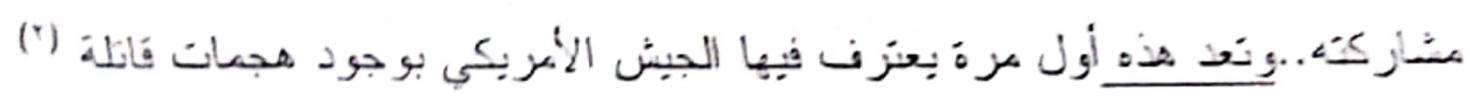

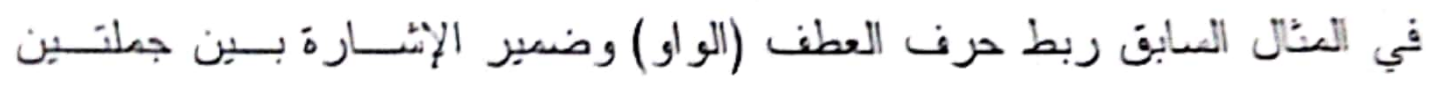

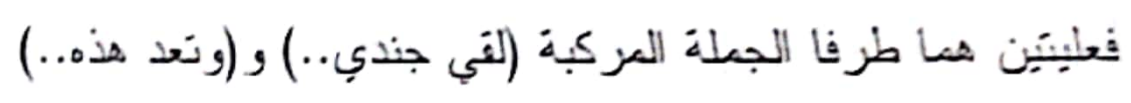
- ومن أمثلة المبط بالأداة وضمبر الغائب والإنشارة: وقَال إن هناك r حر اس جبدين في قطاع النائنين..كما نفي أيضا وجود أبِة نية

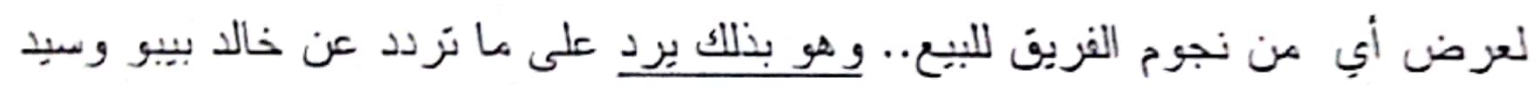

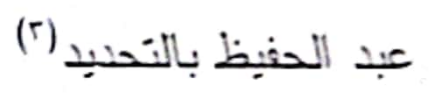

في المثال السابق ربطت أداة العطف وضمبر الغائب (هو) وضــمير الإشــارة (بذلاك) بين الجمل قَبل حرن العطف والجملة بعده. -ومن أمثئة الربط بالأداة وإعادة الذكر :

$$
\begin{aligned}
& \text { (1) الأهر ام ؛ سبتبر 0...rYr. }
\end{aligned}
$$

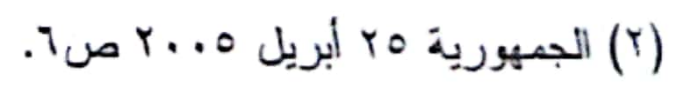

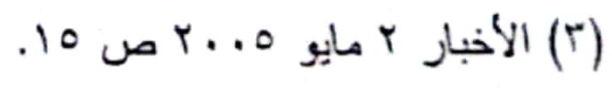


ومن جانبه أعرب طارق العشرى المدرب العام لدرس الحدود عن سـعادئه...

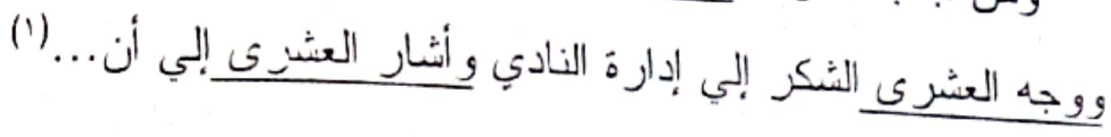

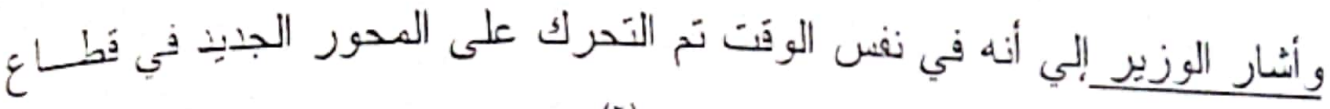

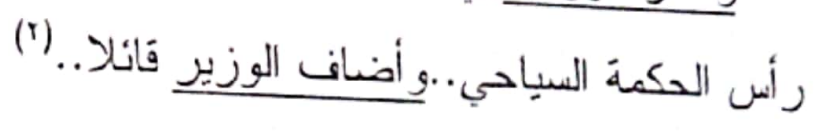

-ومن أمثلة الربط بالأداة مع الضمبر و إعادة الذكر.

-حيث نتعاظم غيرة النساء من بعضهن في الأيام اللاتي يكن فيبها أكثر

خصوبة وتتضاءل هذه الغيرة عندما تتخفض درجة الخصوبة لدى المرأة(")

- - ومن أمثلة الربط بالأداة و الاسنبدال:

- - تجمع حو الي ؛ آلاف عامل في ميدان رنبِي في العاصمة جاكارنا فبـلـل أن يتوجهوا في مسيرة إلي القصر الرناسي.. وطالــبـ المنظـــاهرون بزيسـادة.

(i) الاجور

- فحرف العطف (الو او) وكلمة (المنظاهرون) التي تُنل العنــصر الإحسالي

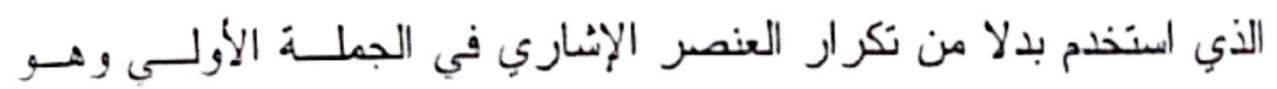
(؛آلات عامل) وقاما بالربط بين الجملة الفعلية (تجمع حو الي ؛ آلان عامل و الجملة الفعلية (طالب المنظاهرون...)

$$
\begin{aligned}
& \text { (1) الأخبار مايو ... 1. ص 10. } \\
& \text { (r) الجمهورية ro أبريل O... }
\end{aligned}
$$

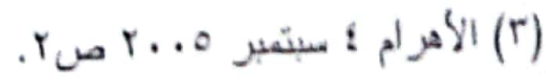

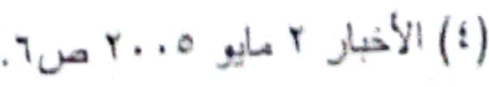




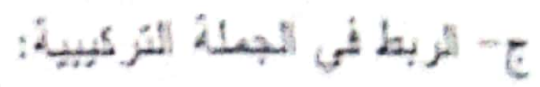

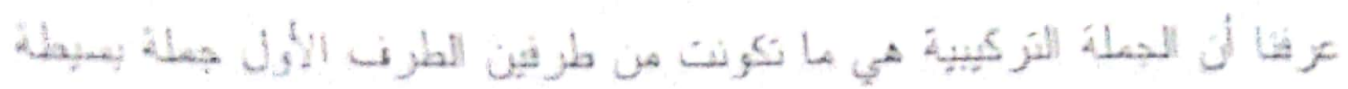

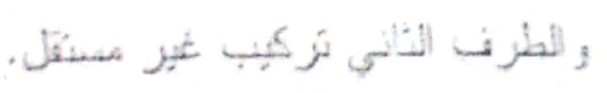

ولتلزبط بين طز في الجملة التزريبية في نص الذبر الصدفي وساتل هي:

$$
\text { أ-الزبط بالأداة }
$$

$$
\text { أ-الزبط بالثاة ومن أمثلة: اللزبط بالأيداة والاحالة }
$$

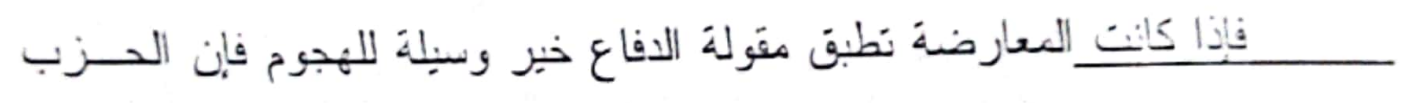

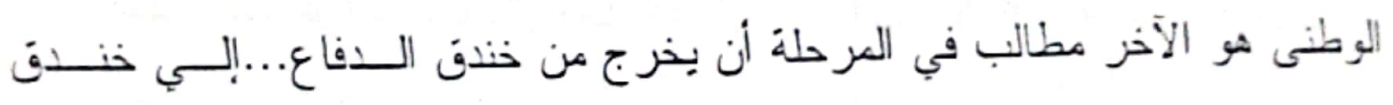

(الهجوم)

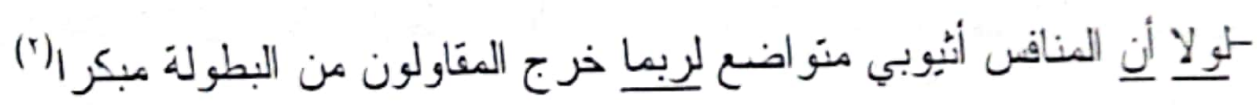
في المنالين السابقين جاءت الجملة التزكيبية جملة شرطبة، جاء الرابط في

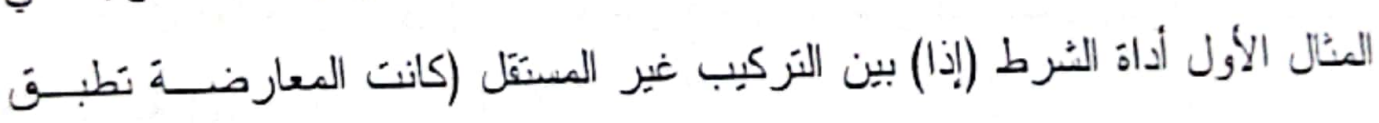
مقولة..) و الجملة بسيطة (إن الحزب الوطني هو الآخر مطالب..)

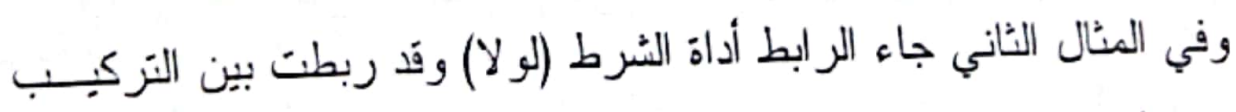

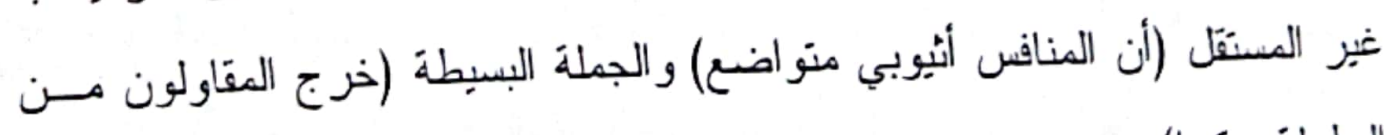
البطولة منكرا)

$$
\begin{aligned}
& \text { (1) الجهورية V يوليو O... }
\end{aligned}
$$

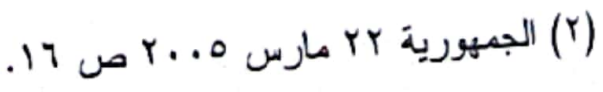


ب- الربط بالأداة والإحالة ومن أمثلته:

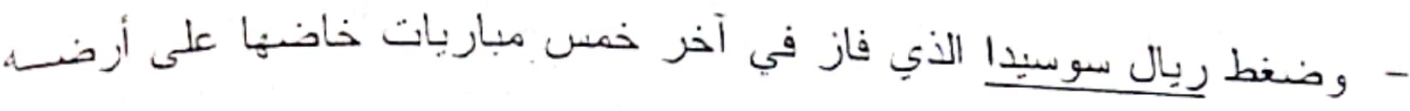

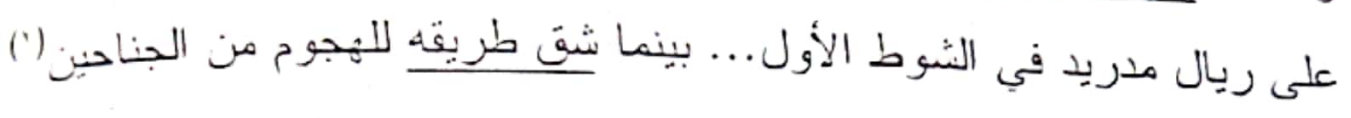
- مو أنه بالر غم من أن مصر لا تمنتك المادة الخام وبعض مدخلات صناعةَ الأثاث إلا أنها مع ذلك تعد مركز لصناعة الأثاث في المنطقة العربية ('). - وكان مشرو ع الذستور الذي حصلت وكالات الأنباء على نسخة منه قَّ نسص

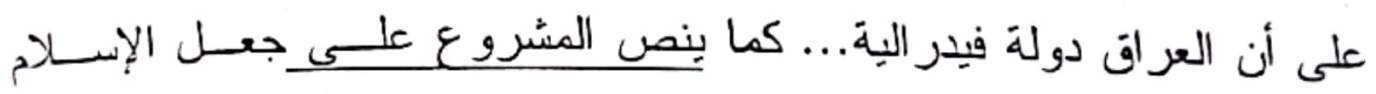
مصدر"ا أساسيا للتشريع ان (r) - ـ وامنكت مظاهرات الاحتفال بعيد العمال حتى المدن الو اقعـــة علــى المدسيط الهادي...بينما ألغيت الاحتفالات في شبه جزيرة كامتشانكا (؛) - في المثال الأول ربط بين طرفي الجملة التركيبية وهما الطرف الأول جملــة (وضغط ريال سوسيداد..) و الطرف الثاني تركيب (شق طريقه للهجوم)عـن طريق الأداة بينما، والإحالة بضمير الغائب المستر في الفعل (شق) و الملحـق بكلمة (طريقه)

- ـ والذي يعود على العنصر الإشاري المعجمي في الجملة وهو (ريال سوسيداد). - ــ وفي المثال الثاني ربطت عبارة (بالرغم من) التي تَّوم بدور أداة الشرط بـين جملة (أنم صر لا تمتلك المادة الخام) ونزكيب (أنها مع ذلك تعد مركـزا...)،

$$
\begin{aligned}
& \text { (1) الأخبار Y مايو 0. . . ص ص17. }
\end{aligned}
$$

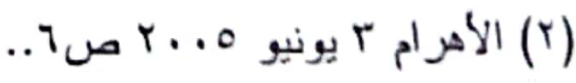

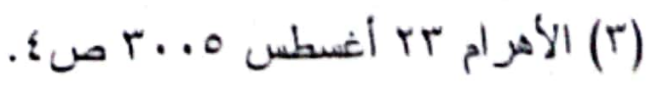

$$
\begin{aligned}
& \text { (:) الأخبار r مايو ه... }
\end{aligned}
$$




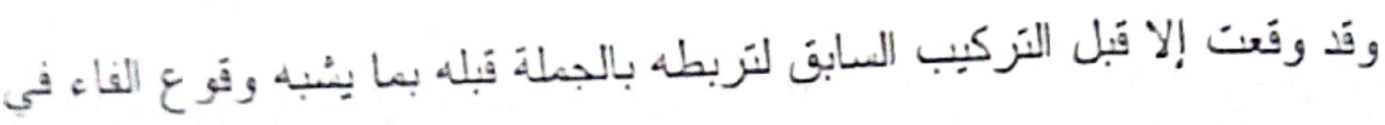
جو اب الشرط.

- وقَ ربط بين الجملة و التزكيب النسابق أبضا عن طريق الإحالة بضمبز الغائب

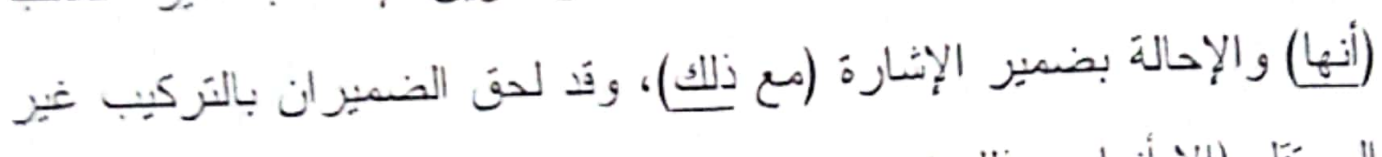

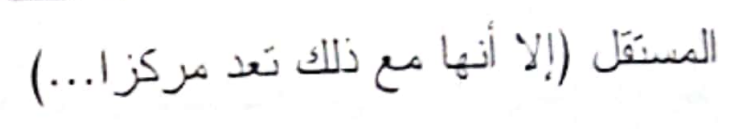

- وفي المثّل الثالث قامت الأداة (كما) و العنصر الإحالي وهن كلمة (المسشروع)

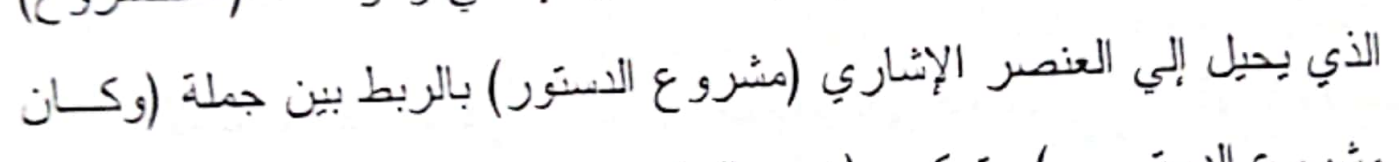

$$
\text { منشروع الدستور ...) ونزكيب (ينص المشزوع على.... }
$$

- - والإحالة في المثال السابق عن طريق إعادة ذكر العنصر الإشاري(مشروع) - - وفي المثال الرابع مثل سابقه ربطت الأداة (بينما) والإحالة بإعادة ذكر العنصر

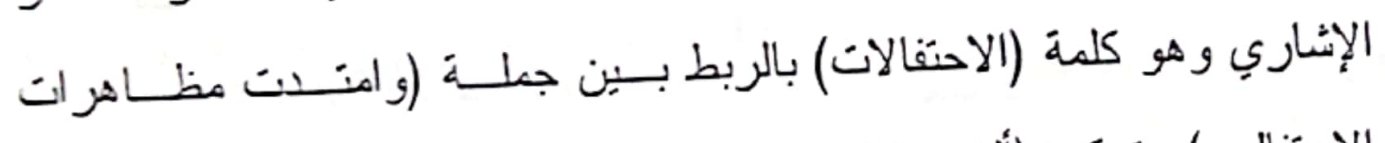
الاحتفال..) وتركيب(ألغيت الاحتفالات في شبه جزيزة كامتثانكا)

- و وإذا كان الربط بالإحالة في الجملة التزكيبية كما وضح مسن خـلد الأمنتـة

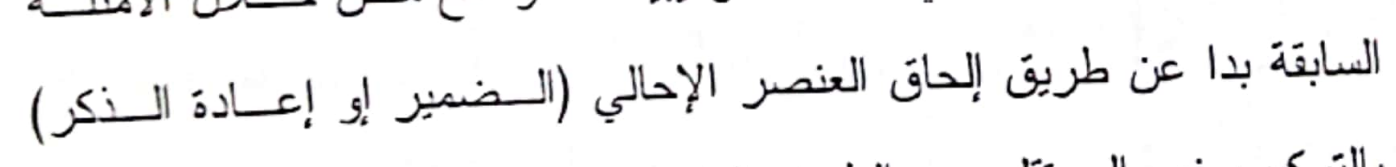

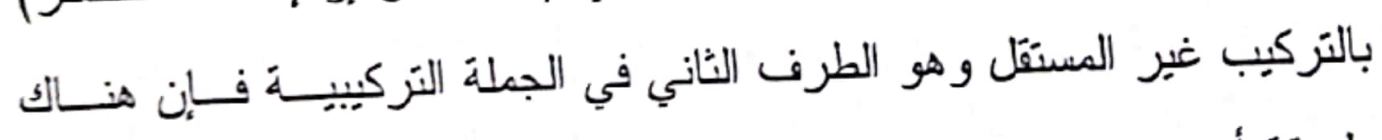

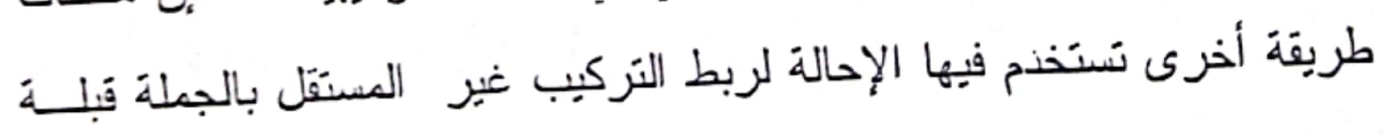

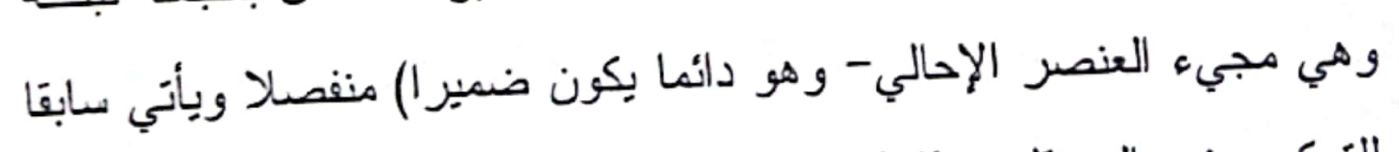

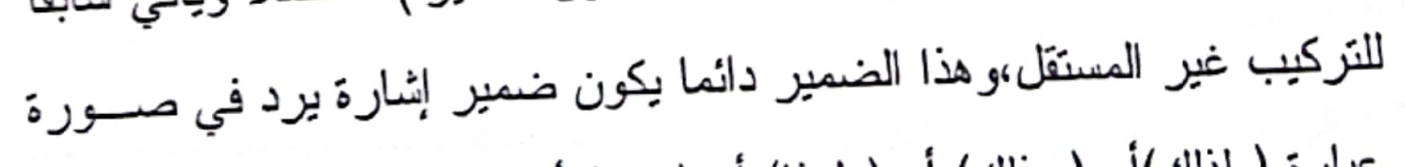

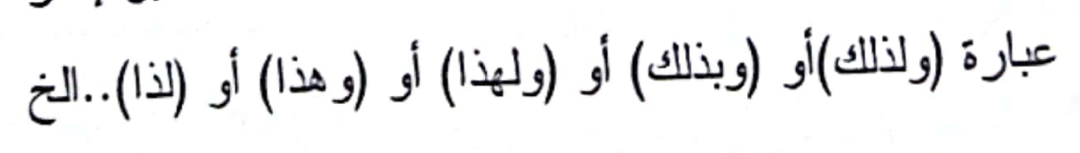

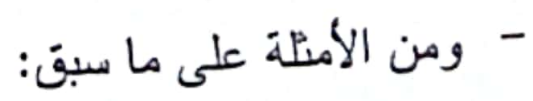




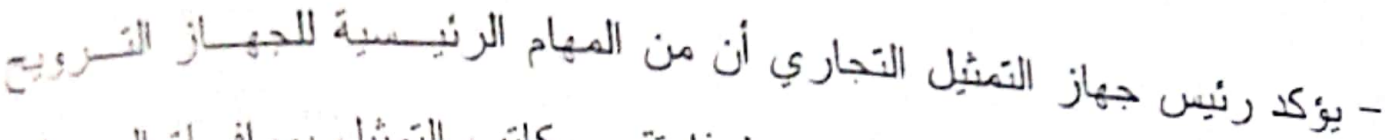

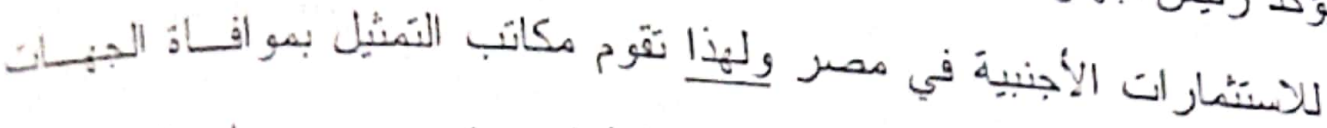

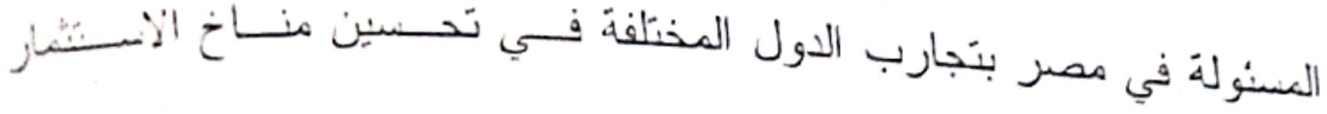
(الأبنبي)

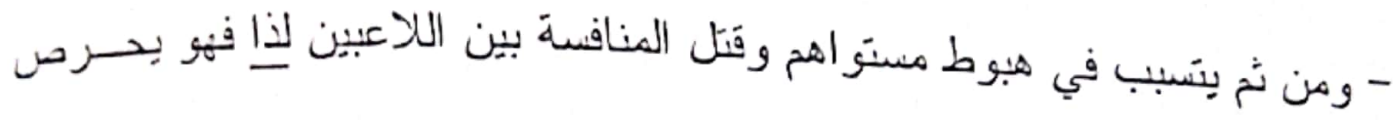
على سربة التشكيل (')

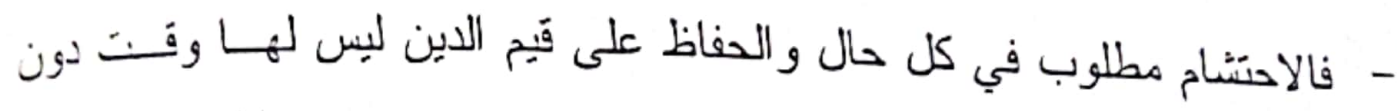

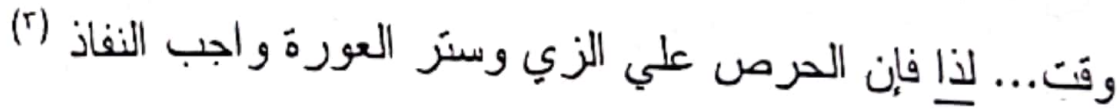

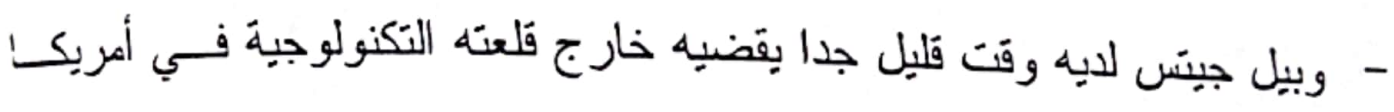

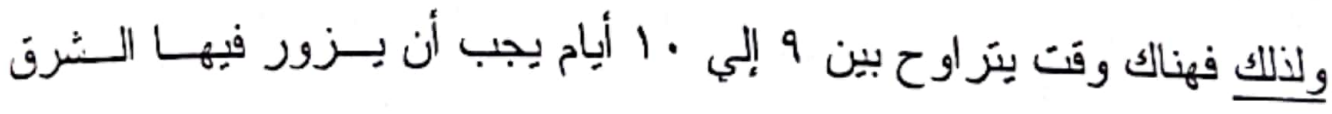

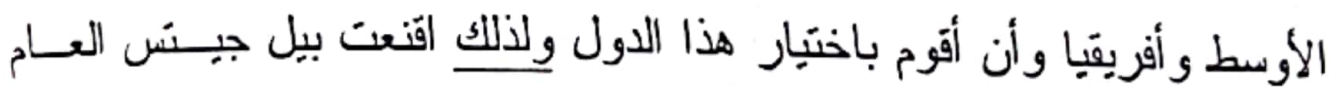
الماضى بزيارة مصر (؛) - الملاحظ في الأمثلة السابقة أن استخدام عبار ات (ولهذا)و (لذا) و (لألك) جـاءت

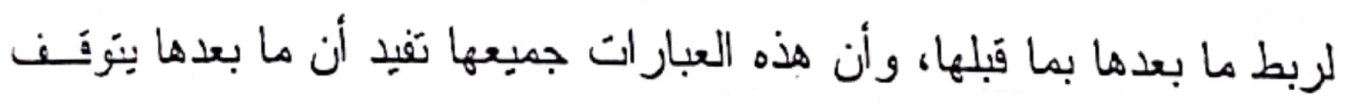

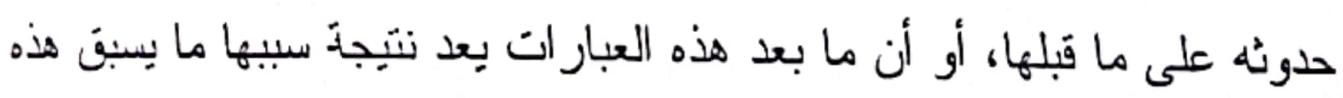

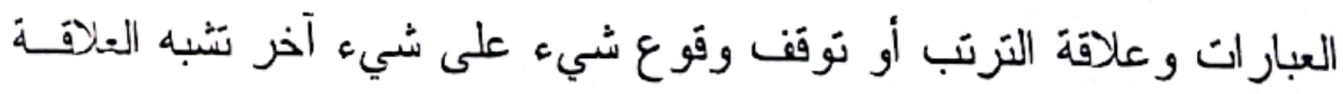

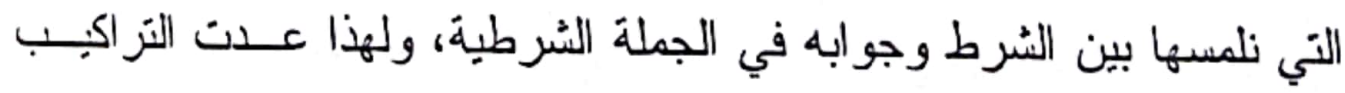

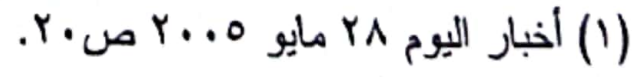

$$
\begin{aligned}
& \text { (Y) الأهرام ع سبتمبر ... Y ص } 19 .
\end{aligned}
$$

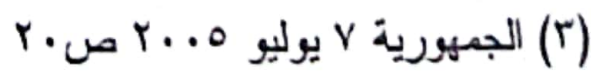

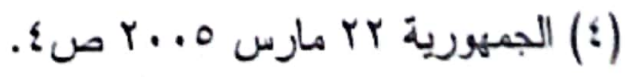


السابقة جمل نركيبية قامت فيها ضمائر الإنشارة بوظنيفة العنصر الإحالي الذي

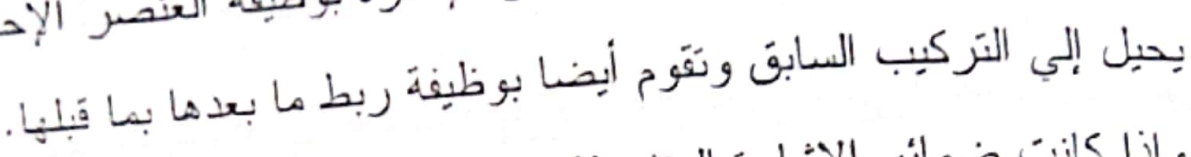

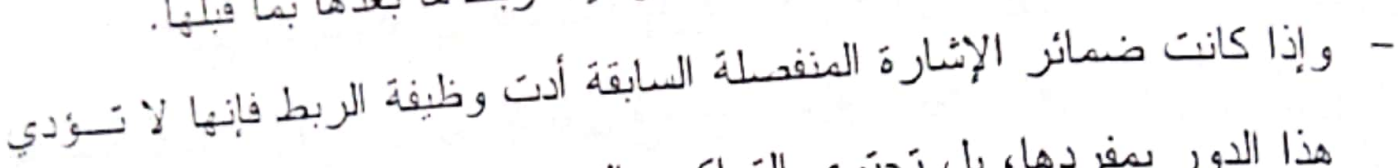

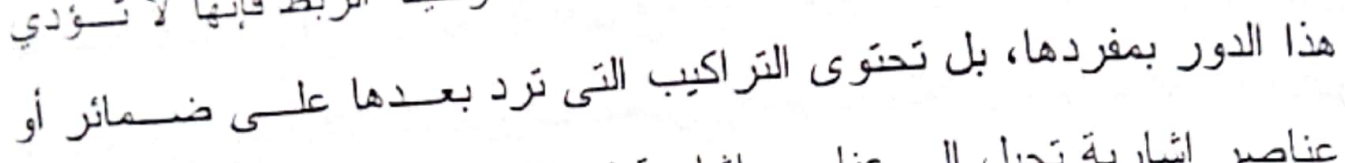

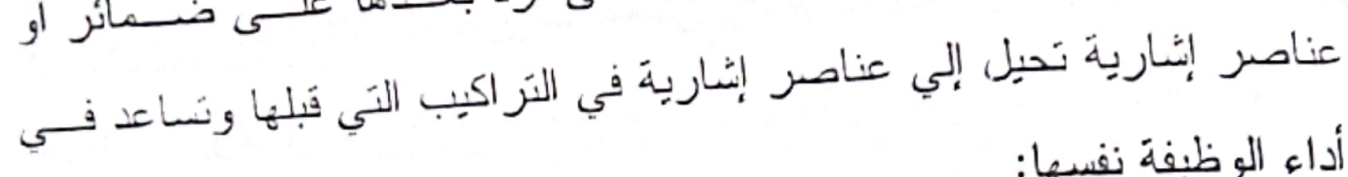
أداء الوظيفة نفسها: - يؤكد رئيس جهاز النمشيلي.... ولهذا تقوم مكاتب التمنبل - وبيل جينس لديه وقت.... يزيور فيها... ولذلك اقتنعت بيل جينس

\section{ثانيا اليترابط في الفترة:}

ذكرت في موضع سابق من البحث أن الفقرة في نص الخبر الصحفي فــــ

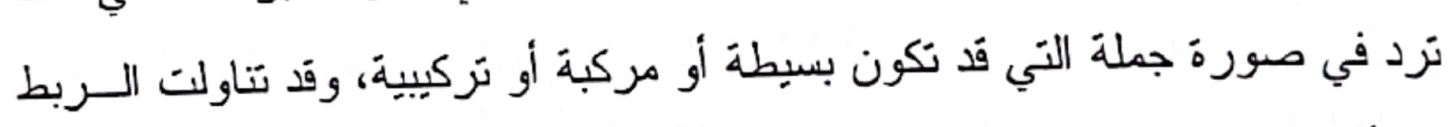

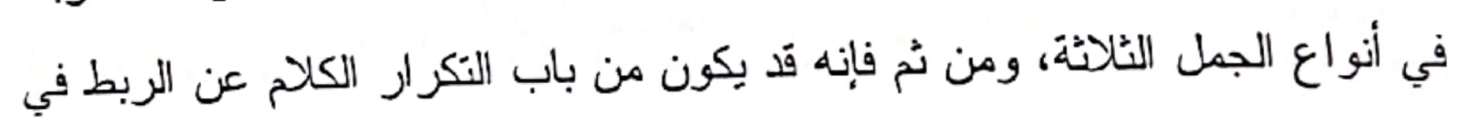

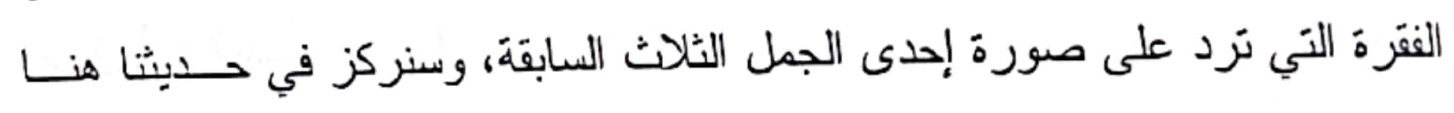
على الربط في الفقرة بصفة عامة دون النظر إلي عدد الجمل أو التر اكيب التي تتألف منها. وتَمتل وسائل الربط بين أجزاء الفقرة في نص الخبر الصحفي في أربــع

$$
\text { وسائل هي: }
$$$$
\text { r- الربط بالأداة و الإحالة بالضمير }
$$

r- (الربط بالأداة و الإحالة بإعادة الذكر

؛- الربط بالأداة والإحالة بالضمير و إعادة الذكر .

وسنقدم أمنالة لهذه الوسائل فيما يلي: 


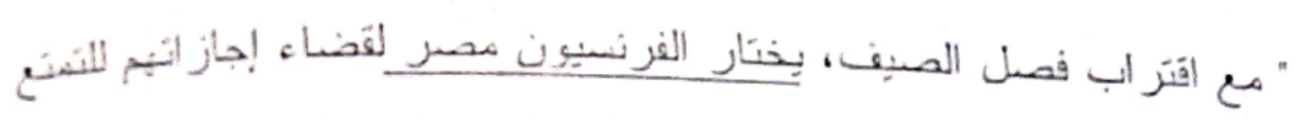

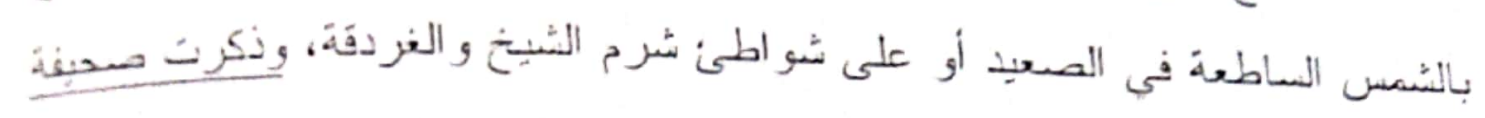

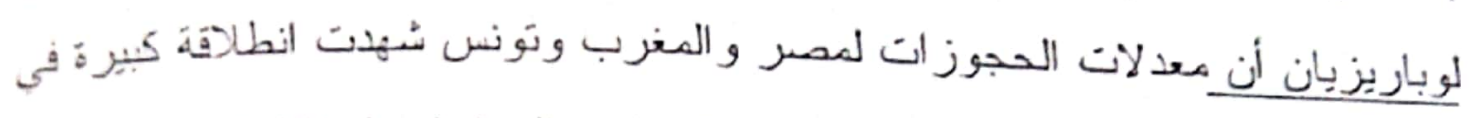
الأونة الأخيرة، و أوضح رونيه مارك مسئول دائرة الدراسات لوكالة السفر الفرنسبة

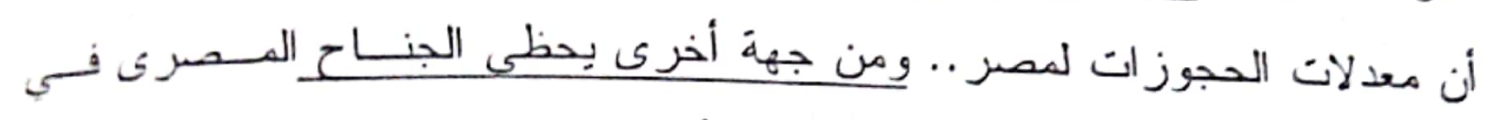
جاكرتا عاصمة إندونسيا... باهنمام كبير ، وأوضح السفير محمد طــه أن الحبــاج و المتنرين الإندونيسيين أبدوا رغبتهم في أن تشمل رحلاتهم للأر اضى الحجازيسة زيارة مصر" (1)

الفقرة السابقة تكونت من خمس جمل فعليــة هـــي "يِختــار الفرنسـسيون مصر ..." "وذكرت صحيفة لوباريزيان أن..." "و أوضح رونيه مارك.." و " يحظـى لئى الجناح المصرى...." و "أوضح السفير محمد طه....." وقد ربط بِينهــا ندوِــا عسن طريق أداة العطف (الو او)

r- الربط بالأداة والإحالة بالضمير ومن أمثلته:

"من ناحية أخرى تحدث الفريق محمد الـششحات محـــافظ مطـروح عـن

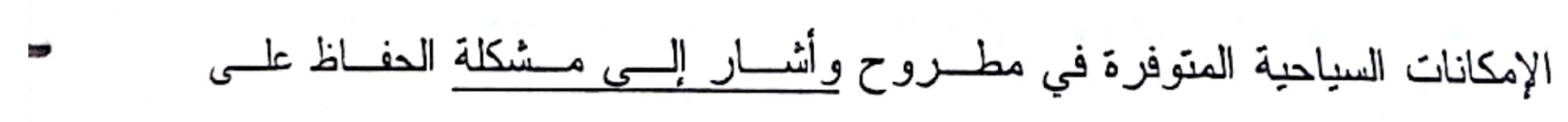
الأرضى. .وقال إنه بعمل على تحويل سيوة إلي محمية طبيعة...و أئشار إلى مخططات المر اكز السياحية في المرحلة الأولي... وقال إن المرحلة الثانية ستشمل سيدي براني

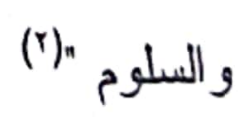

$$
\begin{aligned}
& \text { (1) الأهرام } 10 \text { إيريل ه. . }
\end{aligned}
$$

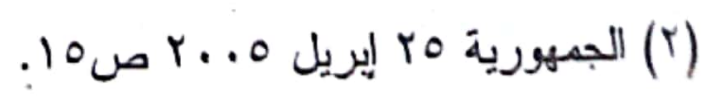


تكرنت الفترة السابقَة من خمس جمل فعلية هي:

(r) (1)

"تحنث الفزبق محد الثُدات " و" أنسار إلي مشكلة الحفاظ..."

(0)

$(\vdots)$

$(r)$

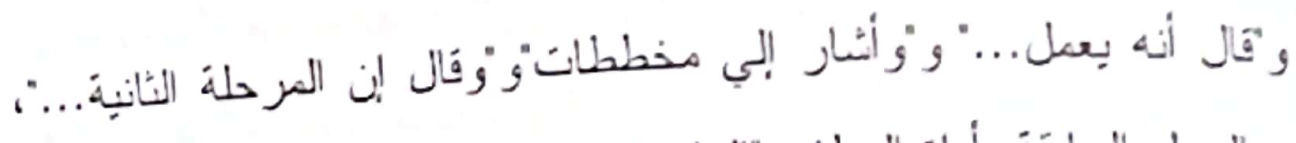

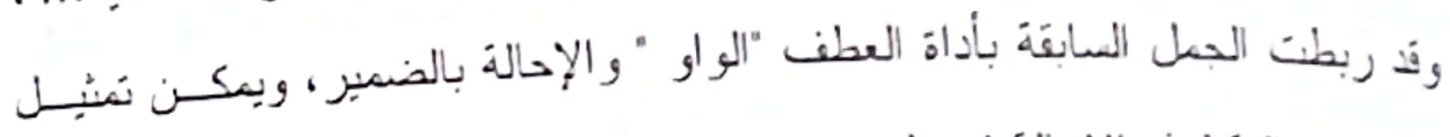
البنبة الإحالية لهئه الإحالة فيم بلي: لئ

$$
\text { البنية الإحالية }
$$

$$
\text { العنصر الأشاري (المرجع العنصر الإحالي }
$$

الضمير المنتر فى أفعال

الفربق محمد النُحات

الجمل الأخري

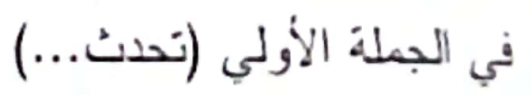

أنشار إلى (')... مَال إنه (ت)

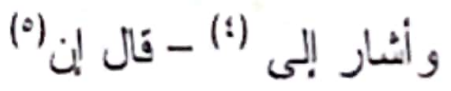

r- الربط بالأذاة و الإحلآة بإعادة الذكر ومن أمثلته:

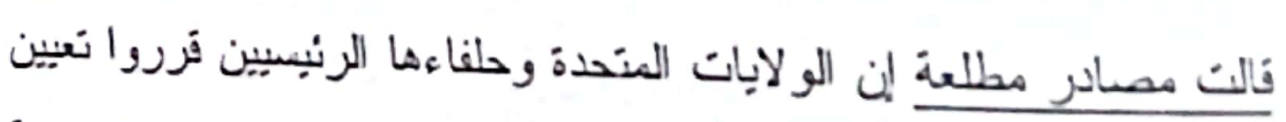

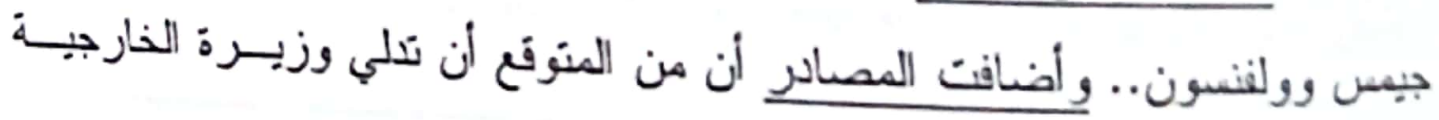




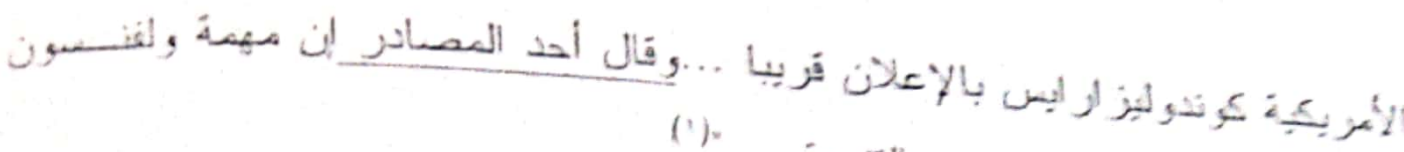

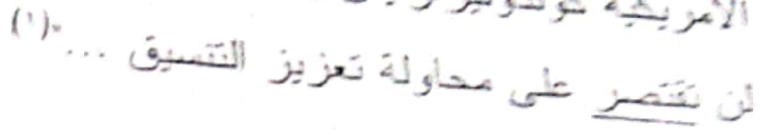

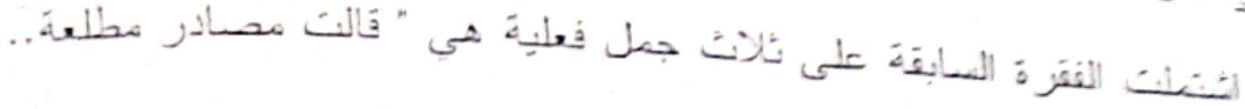

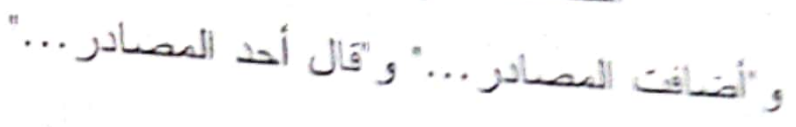

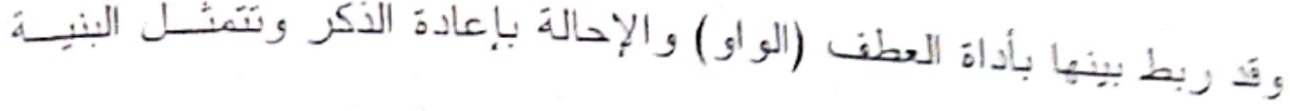

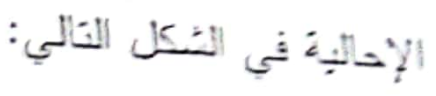

\section{البنية الإحالية}

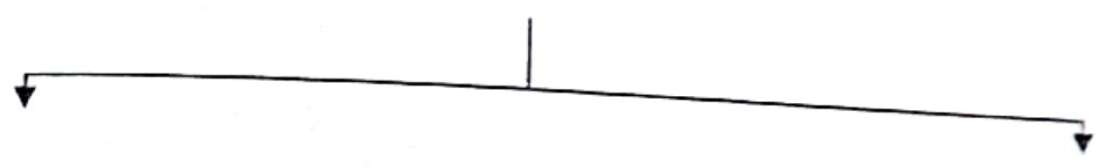

$$
\begin{aligned}
& \text { العنصر الإحالي } \\
& \text { النصن الإثارى هو كلهد } \\
& \text { وهو إعادة ذكر العنصر } \\
& \text { (مصادر) في الجعلة الأولي }
\end{aligned}
$$

الإنشارى وهو كلة مصادر

في الجملة الثانية و الثالثة

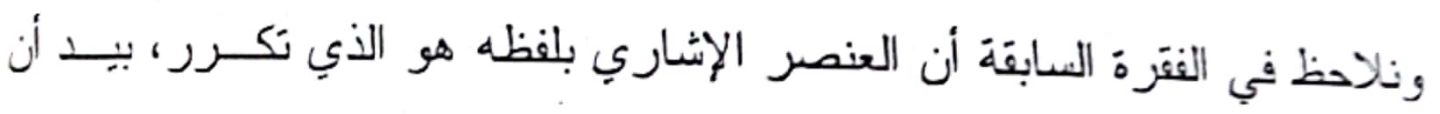

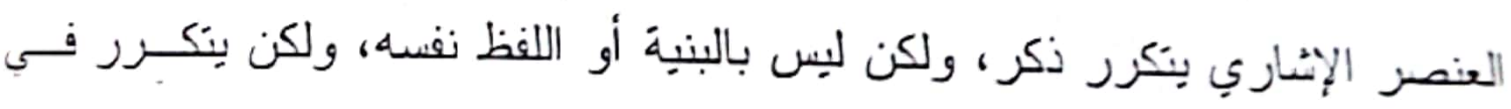
صورة لفظ مشنق منه ومن أمتلنه:ه

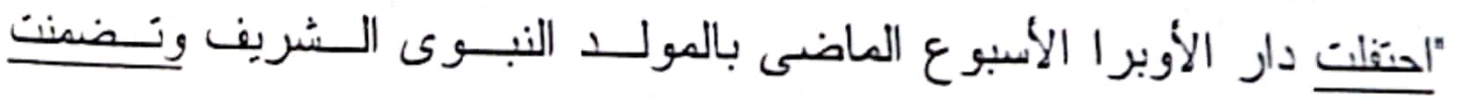

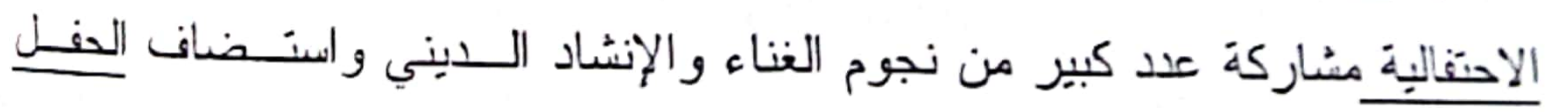

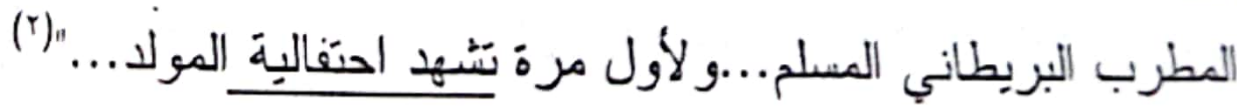

$$
\begin{aligned}
& \text { (الأهرام } 10 \text { إيريل ه... ص صـ. }
\end{aligned}
$$

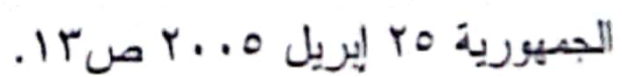





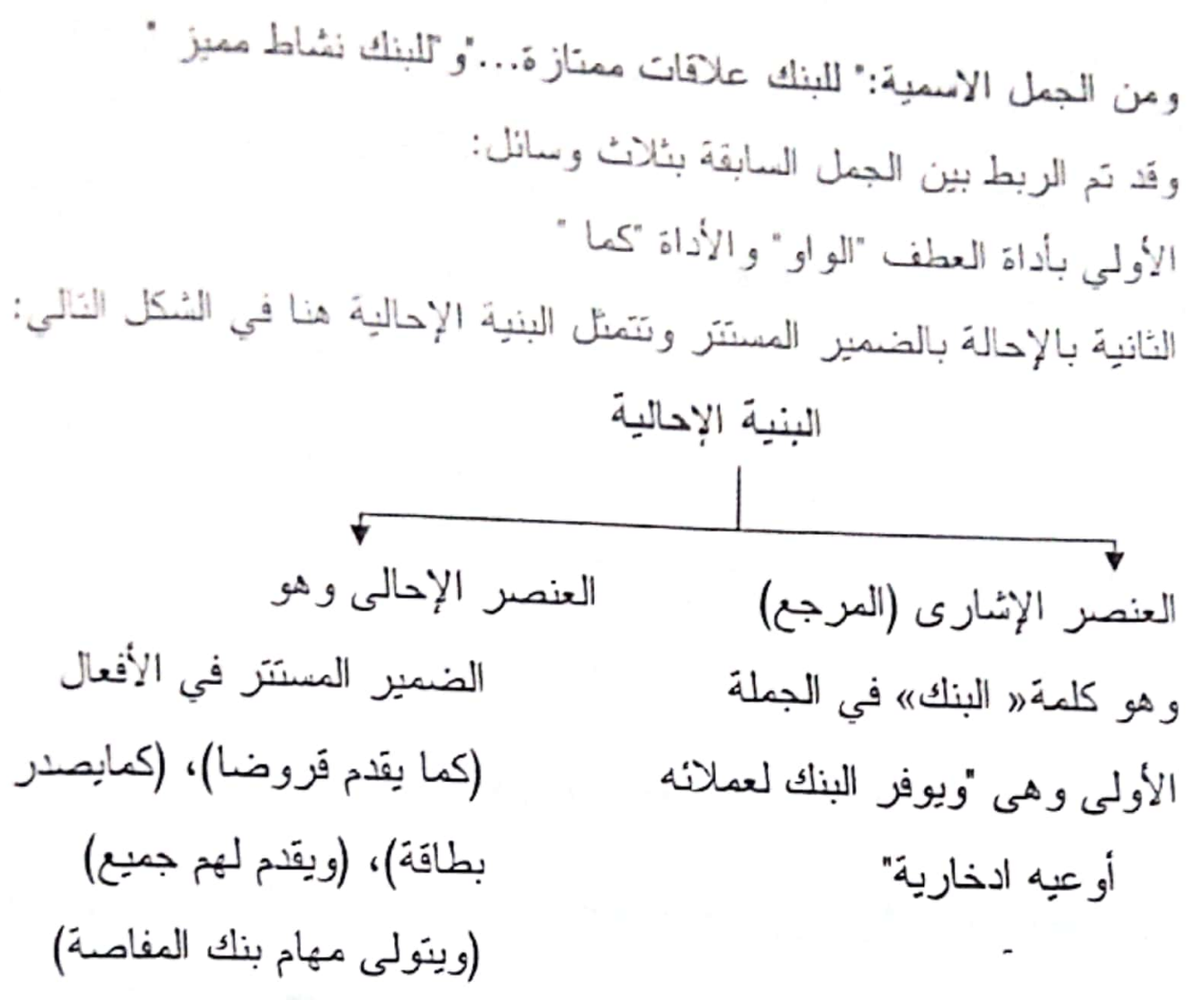

الثُالثة: عن طريق الإحالة بإعادة الذكر ويمكن تَنبل البنية الإحالية، هنا في الثنكل

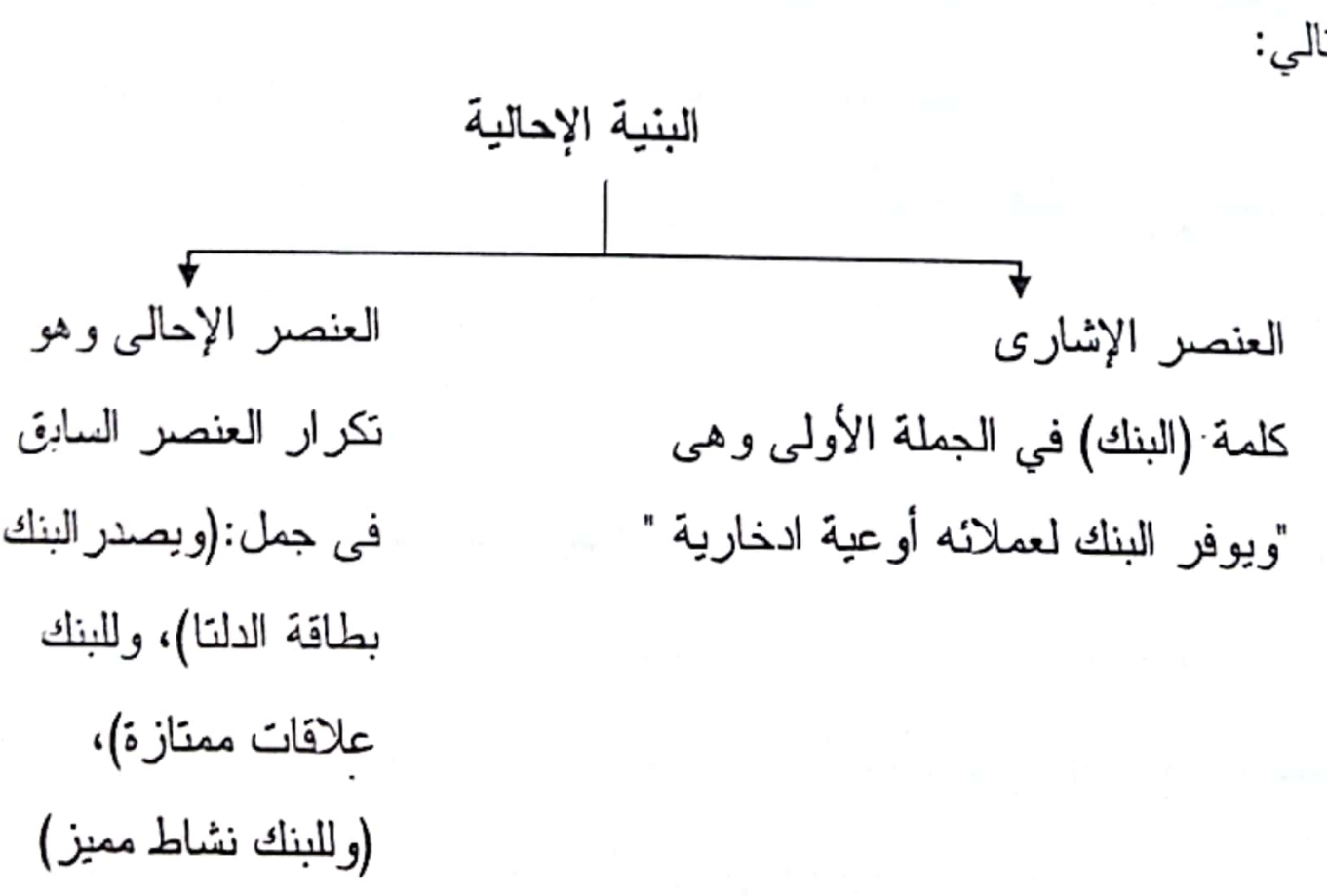

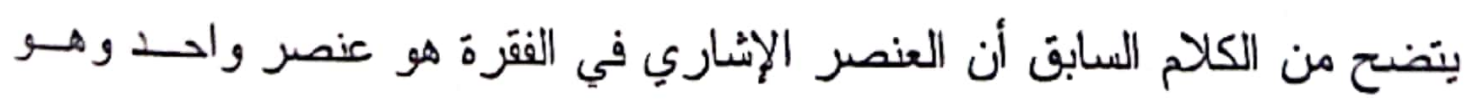
كلمة (البنك) في أول جملة في الفقرة، وتستمر الإحالة عليه طو ال جمل الفقرة بالضمير 


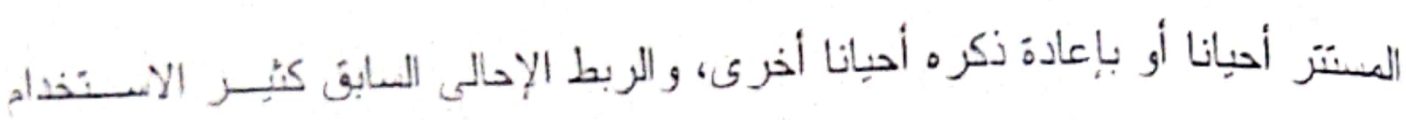
على منسن ى الفقزة ونص الخبر الصحفى.

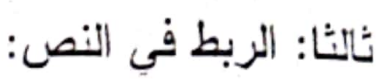

عزفنا أن النص قَد برد في صورة جملة أو فقزة، وقَّ نكلمت سابقا عن الربط في

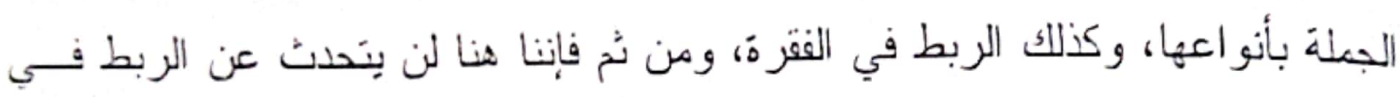
النص الأى برد في صورة جملة أو فقرة بل سنركز هنا في التر ابط النحوى في النص

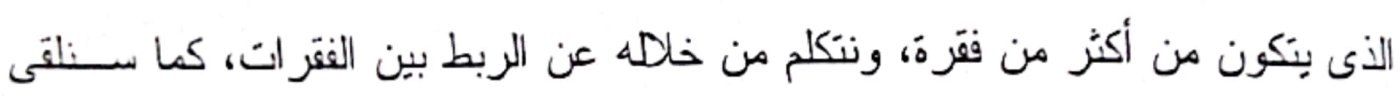
الضوء على التزرابط الزمنى في النص. أ- التز ابط النحوى بين الفقرات في نص الخبر الصحفى: تتر ابط الفقرات في نص الخبر الصحفي بوسائل منها:

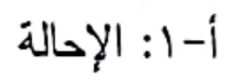

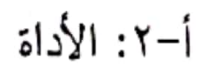
أ-r: (- الأداة والإحالة أ-1-1 (الاحالة

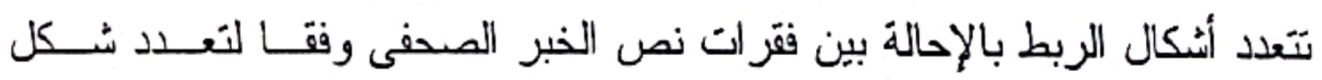

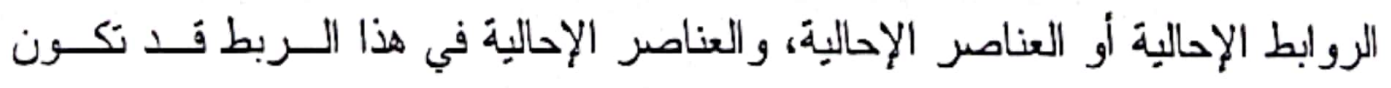
بالضمبر أو بإعادة الذكر، و الحقيقة أن الربط بالإحالة عن طريق الضمبر و إعادة الذكر هو أكثر الوسائل استخداما للربط بين الفقرات في نص الخبر الصحفي، وترد البنيــة الإحالية في نص الخبر الصحفى غالبا في صورة وجود عنصر إبـارى مركزى يـرد في الجملة الأولى أو الفقرة الأولى من هذا النص ثم تستمر الإحالة عليه طو ال الــص فئس 
في فقز اتيه المختفة بالضمير المستزز أو بضمير الإثارة أو الإحالة بإعادة الــذكر ، أي

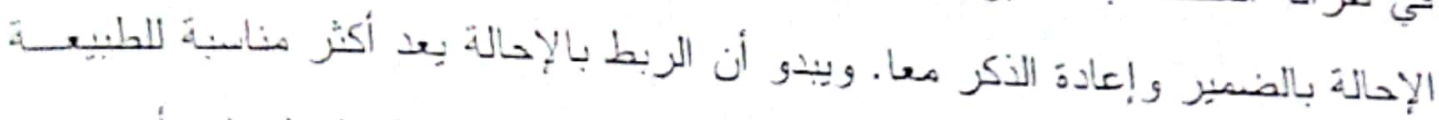

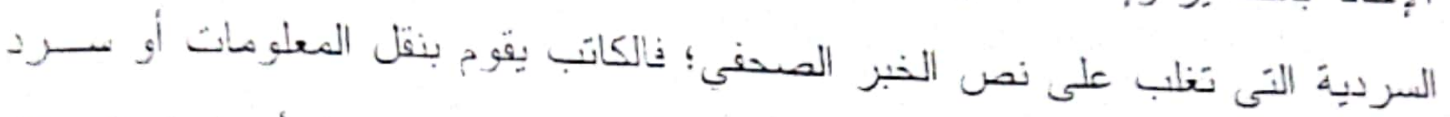
الأحداث من مصادر ها عن طريق إجزاء حوار أو حديث معين معها، أو نقـلـ الكــلام

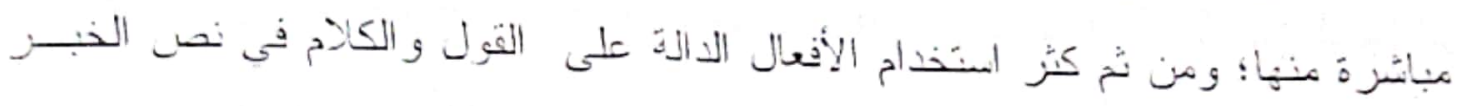
الصحفى. ونقدم أمتعة للربط بالإحالة فيما يلى: - فمن أمتلة الربط بالإحالة بالضمير و إعادة الذكر : - نص بعنوان سوزان مبارك توجه رسالة للأسرة المصرية في احتفــال اليـوم

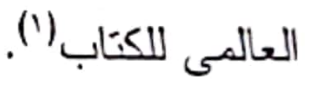
- - الانضمام لنادى المائة بعكس الإيمان بقيمة الكتاب.. المعرفة أساس للانّام. - النص مكون من ثلاث عشرة فترة فيما يلى

الفقرة الأولى: وجهت السيدة سوزان مبارك الدعوة للأسرة المصرية بأن يجعلو ا مسن الاحتفال باليوم العالمى للكتاب وحقوق النشر عيدأ جديدا..... الفقرة التانيةة: قالت إنـ مصر بذلك تصضم للاحنفالية العالميةة.... الفقرة الثالثة: أضافت أنه على مدى ما يزيد على عشر سنوات... الفقرة الر ابعة: قالت السيدة سوزان مبارك في رسالتها إن مصر قررت... الفترة الخامسة: أضافت أن هذا الاحتفال يجيء إيمانا بقيمة الكتاب.... 


\section{الفقرة السادسة: ذكرت البيدة سبوز ان مبارك أنه في عالم البوم.....}

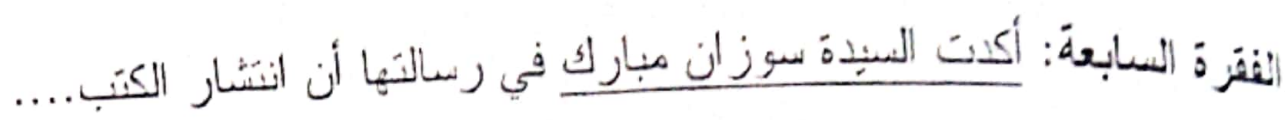

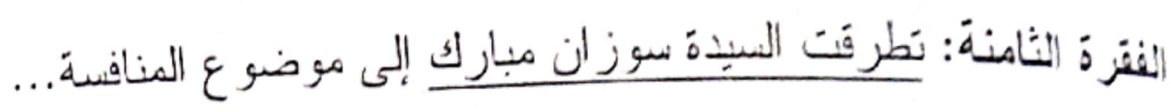

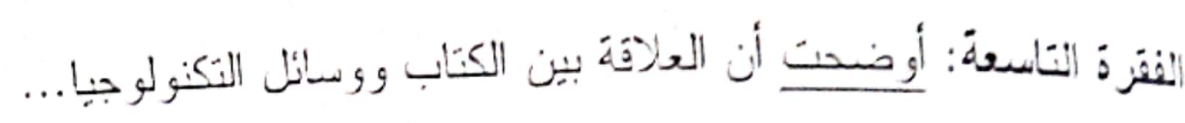
الفقرة العاثُرة: قَالت السبذة سوزان مبارك إن احثفالنا بهذا اليوم.... الفقرة الحادية عثرة: أضافت لو تخبلنا أن هناك ما بزيد على نصف مليون ناشر ..... |الفقرة الثاتية عشرة: أكبت أن مصر منفتحة البوم على العالم.... الفقرة الثالثة عثرة: قَالت السيدة سوز ان مبارك إنتى أقرأ دائما.... بوضح النص السابق أن الإحالة بالضمير وإعادة الذكر لها الدور الأساسـى

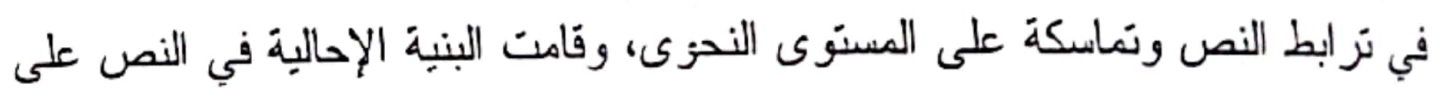

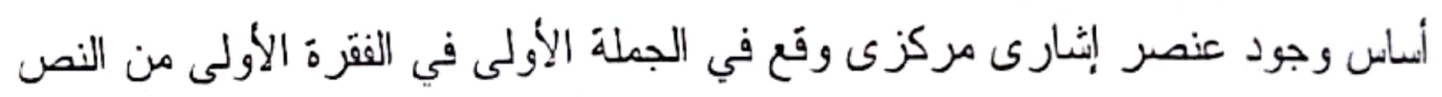
وهو " السبدة سوزان مبارك)، واسترت الإحالة على هذا العنصر الإثــارى أحيانسا

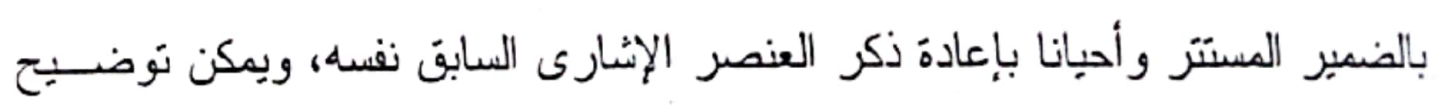

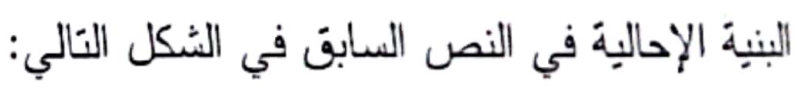




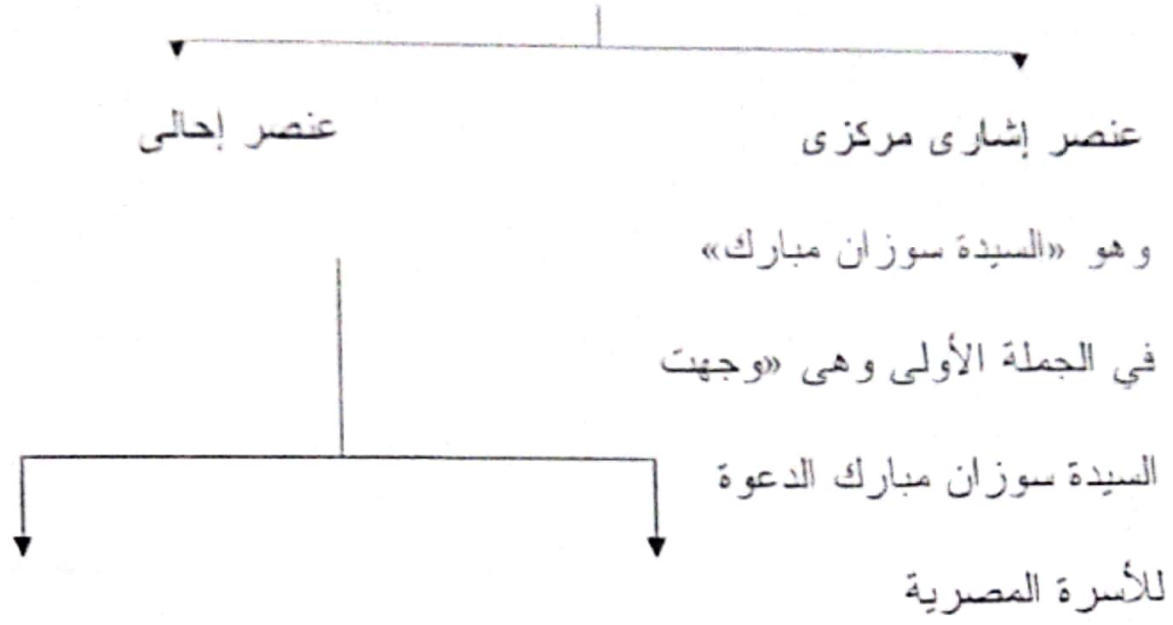

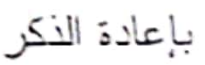

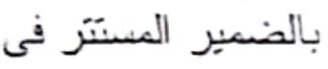

عن طريق نكرار العنصر

الأفعال التَى تبندأ بها

الإنشارى المركزث وذيك

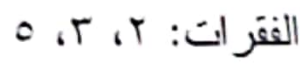

في الفقرات ؛، ז، V، •11، TI

$14 ، 11 ، 9$

ومن أمثلة الربط بضمير الإنشارة:

- نص بعنوان أخلاقِيات البحث العلمى أمام لجنة النعليم (")

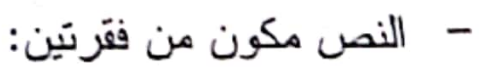

الفقرة الأولى: تعد لجنة التعليم والبحث العلمى بالحزب الوطنى با ورقَة

عمل في مجالات النعليم... وكل ورقةة تعدها مجموعة عمل وينتم اختبِار مقرر لها.

الفقرة الثانية: صر ح بذلك د. حسام بذراوى رئيس اللجنة وقال ....

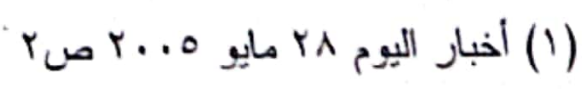


في النص السابق زبط بين فقرتبه عن طريق الإحالة بضمبر الإشارة (بذلك) الو ارد

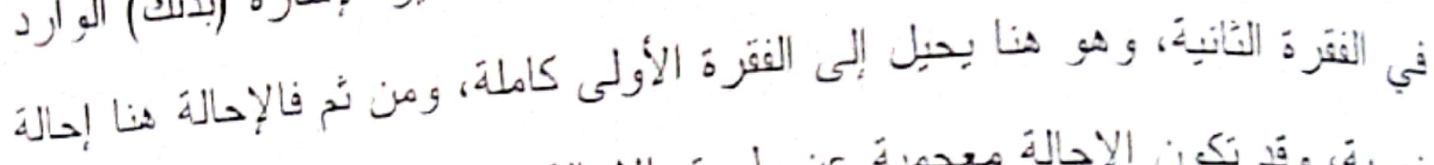

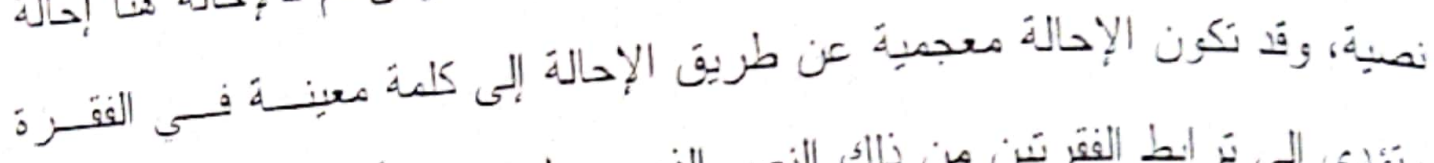

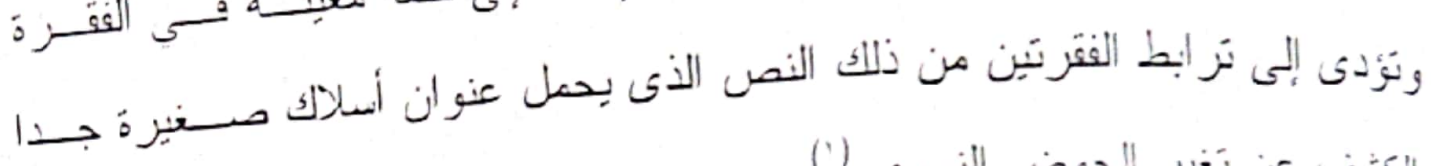

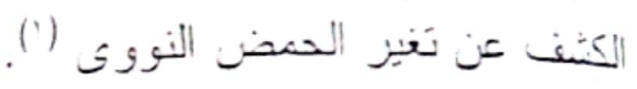
بتَألف النص من ثلات فقر ات: الفقرة الأولى: أعلن العلماء ... أنه بمكن كثنف الحمض النووى... وذلــك باستخدام مجس مصنوع من الأسلك المتتاهيةَ..... الفقرة الثاتية: ويمكن تصنيع تلك الأسلك..

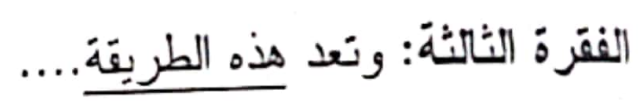

وقد ذكرت فَبل ذلك أن ضمير الإنشارة بمختف أثناله بؤدى دورا كبيـرا

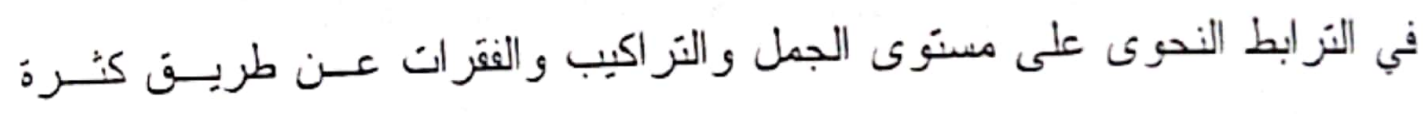
استخذامه في نص الخبر الصحفى قَبل الجار و المجرور والظرن ومتعلقه و المصادر المنصوبة، وعن طريق وروده في عبار ات منضامة نحو: بناء على هذا، ومن هـــا المنطلق، ومن ثُث، صرح بذلك، أنشار إلى ذلك، أكد ذلك، وفي غضون ذلك، و أكتــر من ذلك...... الخ

وورود خميز الأشارة في مواقع مختلفة من أجزاء النص بـسـاعد علـى تُر ابطه، ونماسكه على المسنوى النحوى. - ومن أمتنة الربط في نص الخبر الصحفي بإعادة الذكر: 
- نص بعنو ان: إدانه ضابد أمريكى بنقل ترسانة: أسلدة صغيرة من العـراق

لبلاده (")

النص مكون من فقرتين:

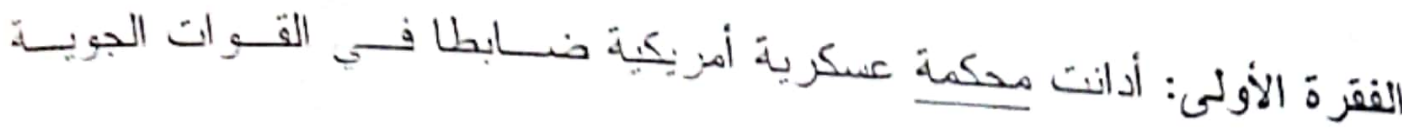
الأمريكية...

الفقرة الثانية: أكدت المحكمة أن الرائد جردجى مكميليون مذنب... ربط بـبين

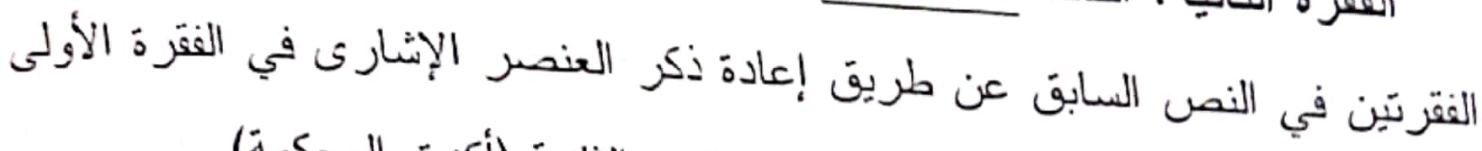
و هو كلمة (المحكمة)، فقد نكرر ذكرها في الفقرة الثانية (أكلت المحكمة).

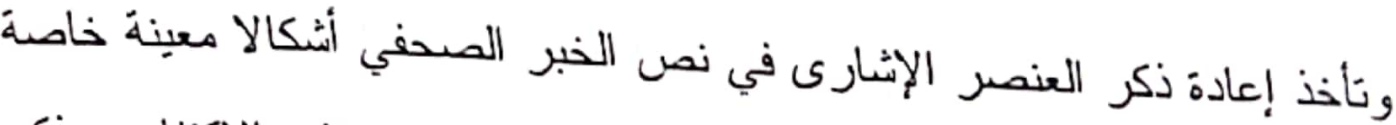

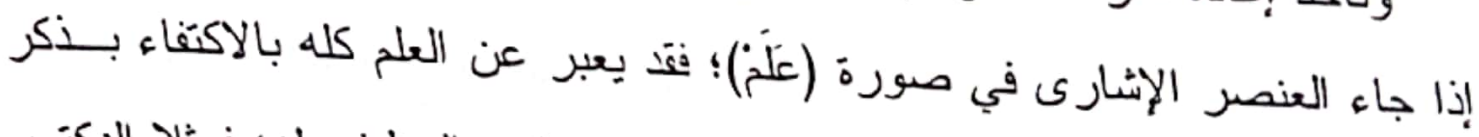
اللقب أو جزء من العلم، وأحيانا بعبر عن العلم كله باللقب الوظيفي له؛ فمثنلا الدكتور

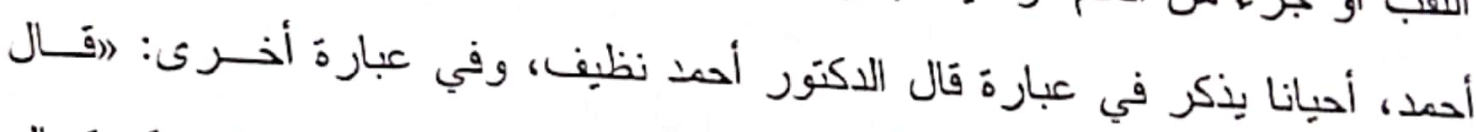

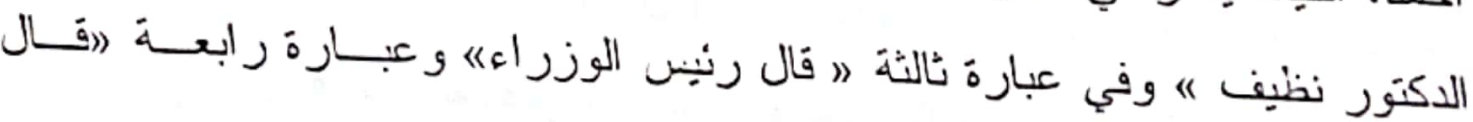
الوزيرها...

وكذلك بالنسبة للعلم الذى يمثل اسم " يوسن الدهشورى حرب" بعبر عنه أحيانا

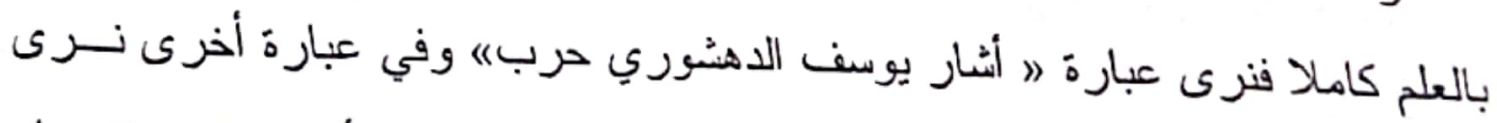

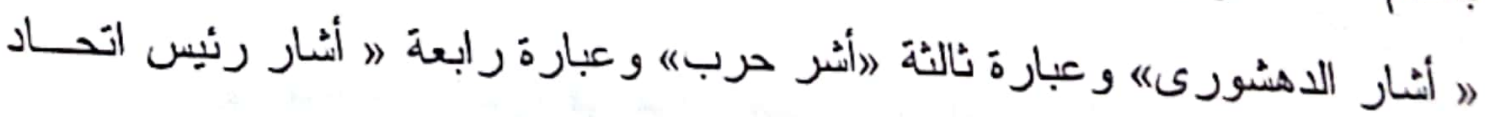




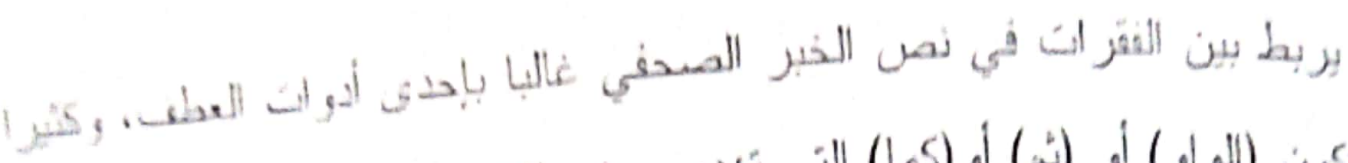

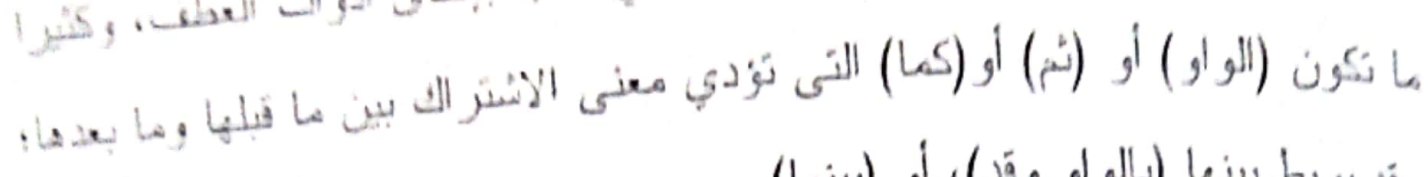

$$
\text { وقد بربط بينها (بالو او وقة )، أو (بينما). }
$$

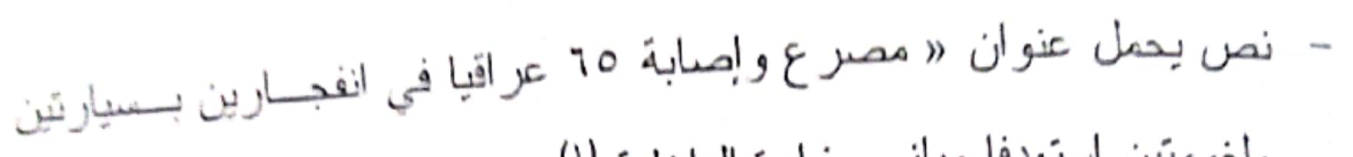

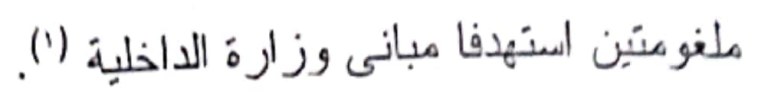

- النص مؤلف من إحدى عشرة فقرة:

الفقرة الأولى: لقى ع بُخصا على الأقل مصر عهم واصيب أكتر من 1؛ أخربن.... الفقرة الثانية: وذكر مصدر في وزارة الداخلية العر اقتية أن الهجوم... الفقرة الثالثة: وأوضح مر اسل وكالة الأنباء الفرنسية أنه.... الفقرة الرابعة: وفي وقَت لاحق هز انفجار ثالث المنطقة ذاتها.... الفقرة الخامسة: وفي بغداد أبضا أعلنت مصادر في الشُرطة العراقية.. الفقزة السادسة: وفي كركوك لقي "آمن رجال الشرطة... الفقرة السابعة: وذكرت مصادر أمنية أن مسلحين... الفقرة الثامنة: وفي الوقت نفسه أعلنت القوات المنعدة الجنسبات.. الفقزة التاسعة: وفي بعقوبة أصيب جنديان أمريكيان.... الفقرة العاثشرة: وعلي صعيد الأوضاع السياسية.. الفقرة الحادية عشرة: ومن جانبه حمل فؤ اد مبصوم....

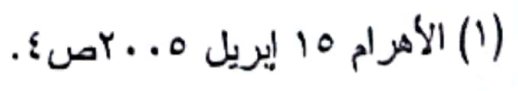




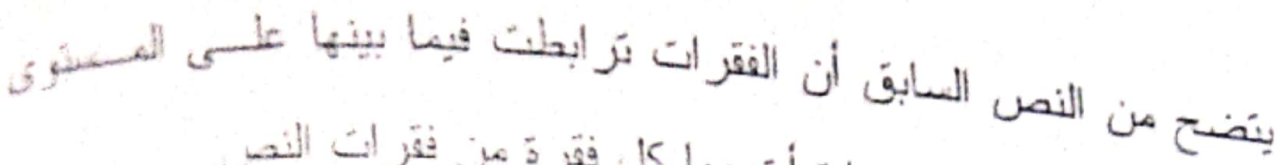

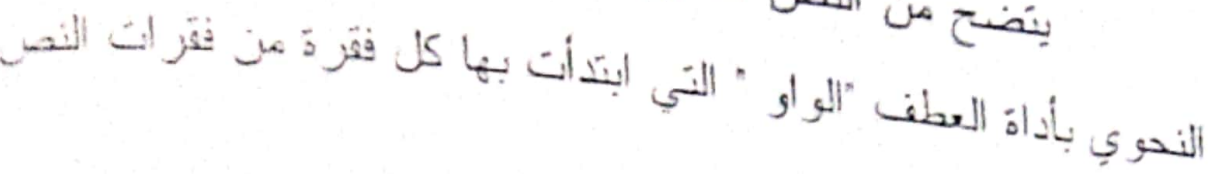

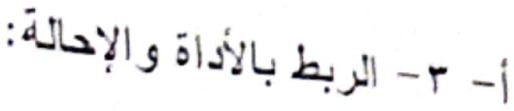

يجمع هنا في الربط بين الفقرات في نص الخبر الصدفي بالو سبلتبنين السبائ.

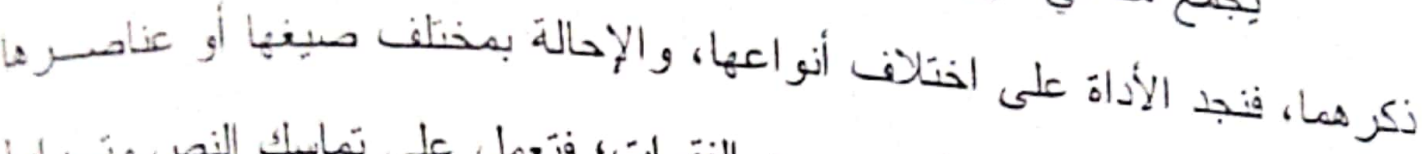

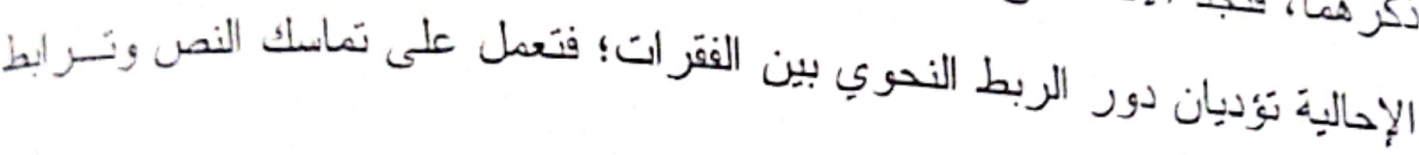

ويبذو الجمع بين أكثر من وسيلة للربط بين الفترات واضحة كلهـا طــال

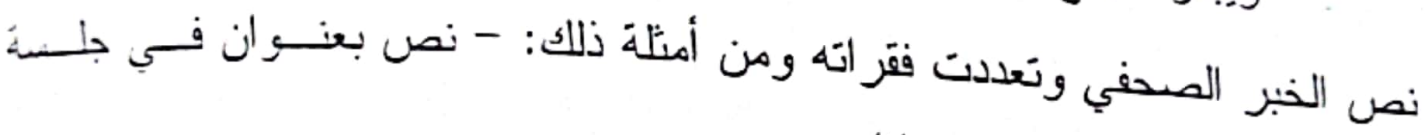

ختامية حضرها كل الأعضاء (1)

مجلس الشعب يشيد بالسياسة الحكمية للرئيس مبارك وخطو ات الإصلاح - جاء النص مكونا من أربع عشرة فقرة:

الفقرة الأولى: في جلسة شهت أعلى نسبة حضور .. أعلن د. سرور فض السـورة و أشاد المجلس بالسياسة الحكيمة التي بنتهجها الرئيس حسني مبارك.... الفقرة الثانية: وكان الدكتور سرور قد ألقى بيانا حول انجازات المجلس... الفقرة الثالثةة: و على الصعيد الخارجي قال د. سرور إن المجلس تناعل... الفقرة الرابعة: وأضاف رئيس المجلس أن دورة الانعقاد الحالي... الفقرة الخامسة: كما عقدت اللجان النوعية و المشتركة....

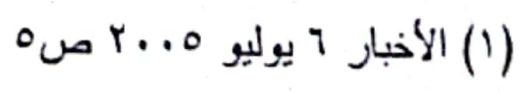




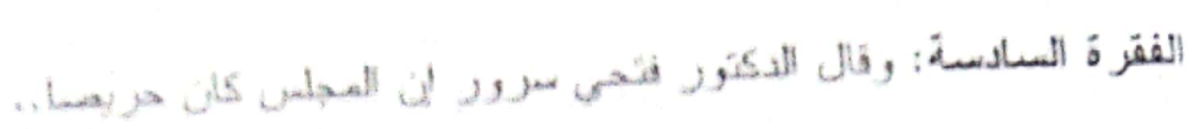

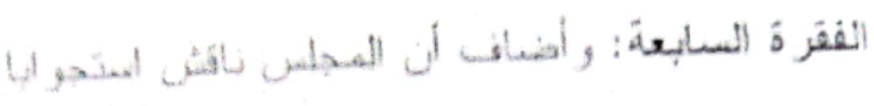

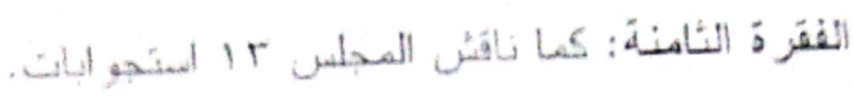

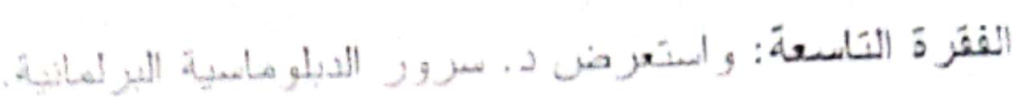

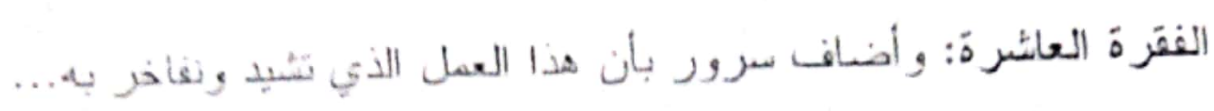

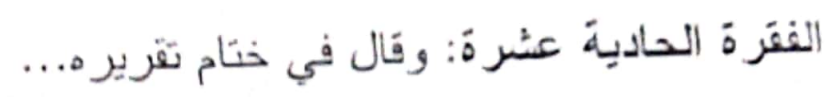
الفقرة الثنانية عشرة: ثُّ تحدت بعد ذلك كمال الثشاذلي........ الفعرة الثالثة عثرة: ثُ ألقى د. أحمد نظيف رنيس الوزراء بيانا... الفقرة الر ابعة عشرة: وقَال إن استثمار ات المشرو عات... بوضح النص السابق أن فقراته تر ابطت فيما بينها (بالأداة) التي نتبلت في

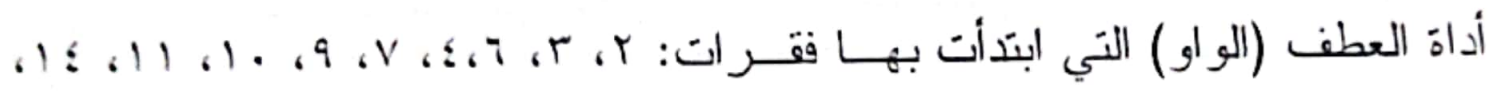
و أداة العطف (نم) التي ابتدأت بها فقرات ب ا، ب ا، وكذلك تزابطت الفقرات بالأداة

$$
\text { (كما) التي ابتدأت بها فقرات 0، } 1 \text { م. }
$$

وقد اشتركت الإحالة مع الأداة في الربط بين فقرات النص السابق أيضا، وقَد تَوعت العناصر الاحالية في النص فشملت الضمير المستتر، ضمير الإشارة، وإعادة الذكر. ويمكن تمثيل البنية الإحالية للنص السابق في الشكل التالي: 


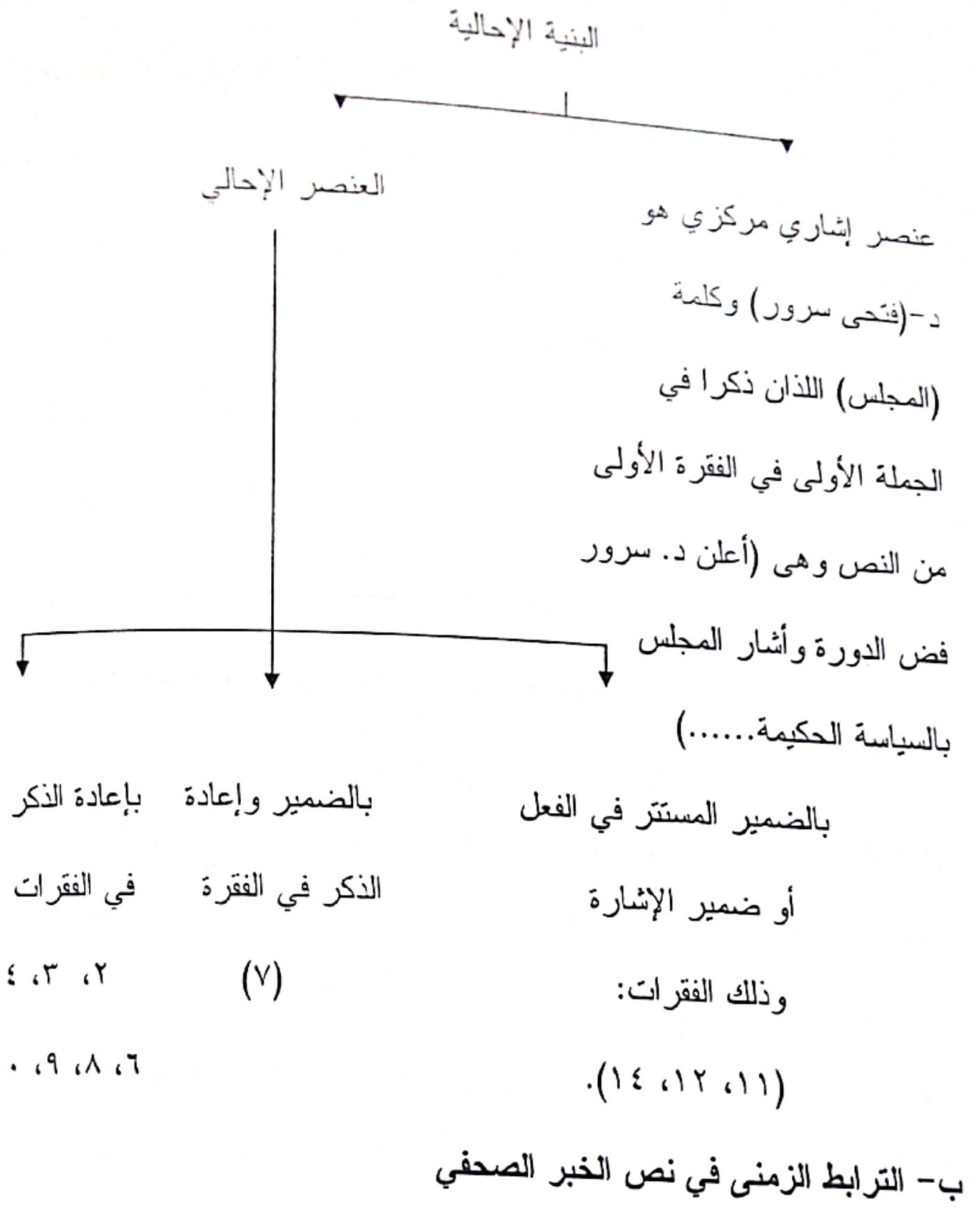

ذكرت فيما سبق أن بناء نص الخبر الصحفي من حيث الشُكل و المـضمون يقوم على أساس الشتماله على عدة عناصر هى: الحدث وأطراف الحـدث وزمسن فئ

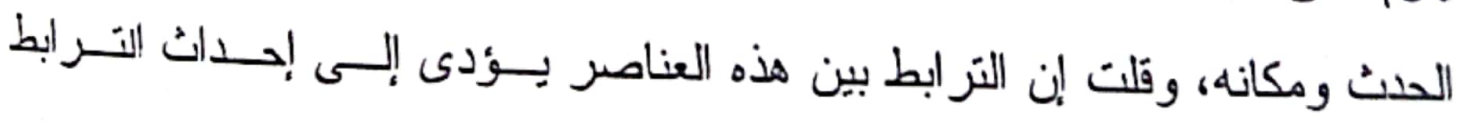
و التماسك في النص بوصفه وحدة لغوية تستخدم في تحقيـقن التواصـلـل و التفــاهم، وهاتان الخاصيتان هما اللتان تحققان للنص سمة النصية. 


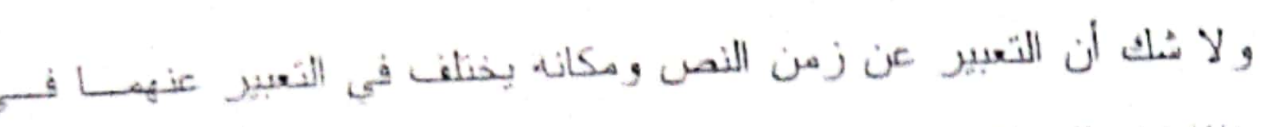

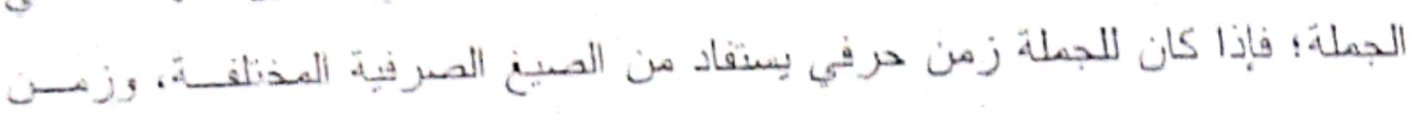

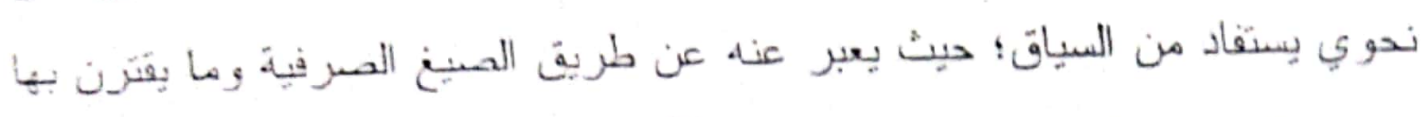

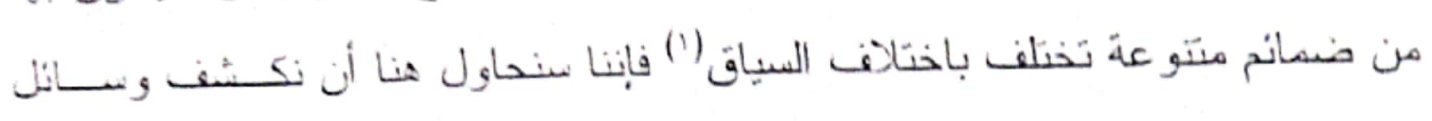
التعبير عنه في نص الخبر الصحفي في النقاط الثلالبة: ب- 1: التعبير عن زمن النص ومكانه في مقدة النص: غالبا ما يعبر عن زمن النص ومكانه في الجملة الأولى مسن نــص الخبــر

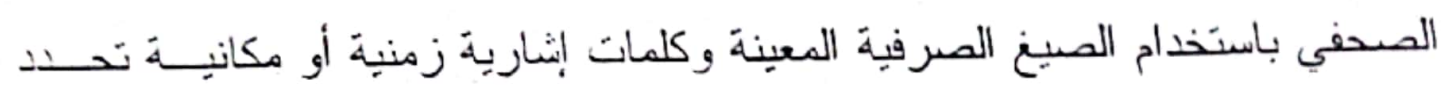
جهة الزمن، ومن هذه الكلمات مساء أو مساء أمس أو أمس أو صباح اليوم أي هــــا الأسبوع أو أحد أيام الأسبوع؛ كالقول مثلا بوم الخميس أو السبت.... إلخ. ومن سمات الإحالة الزمنية في نص الخبر الصحفي: 1- أنها غالبا ما تكون إحالة إنشارية مقيدة؛ بمعنى أن السرد الإشاري الـــى

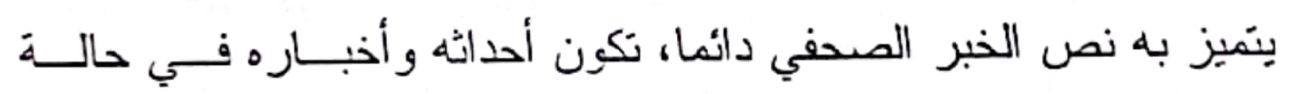
تجاوز مع زمن كتابة النص أو قريبة منه وكذلك نجد هذا التجاور بـين أحداث النص ومكان وقو عها؛ فالسرد الإشارى في نص الخبر الصحفي له حدود وضوابط " فهو يقتصر فقط على ما بمكن أن يعد منجاورا في الزمن مع الكتابة أو بالأحرى، ما بمكن الإحالة إلِيـهـه بعلامـــات زمنيــة

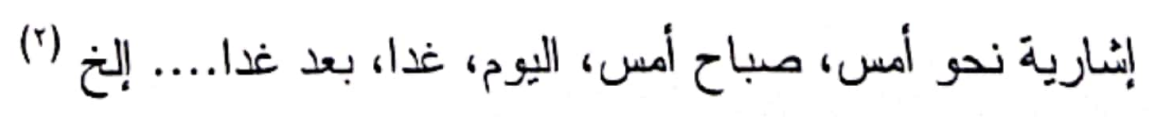

(1) انظر الدكتور تمام حسان: اللغة العربية معناها ومبناها ص • ؟Y-YOV. (ץ) مريم فرنسيس: في بناء النص ودلالته " بتصرن يسير ه صل111. 


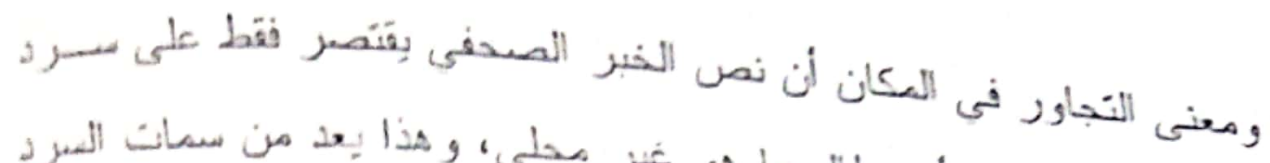

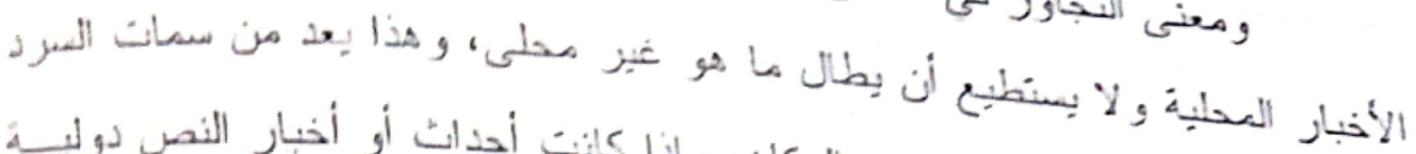

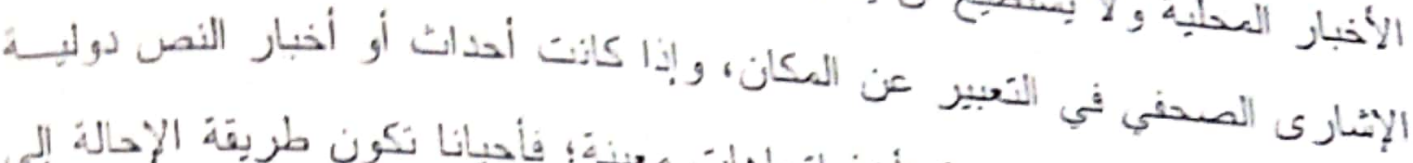

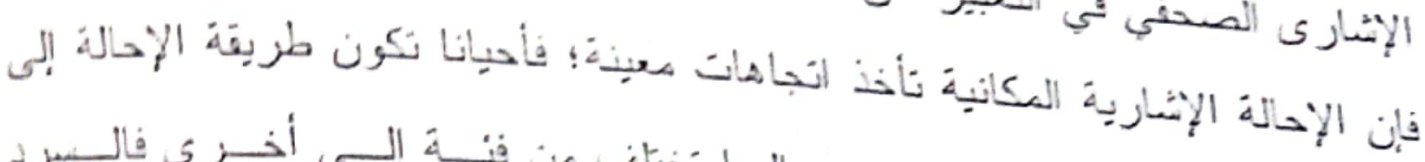

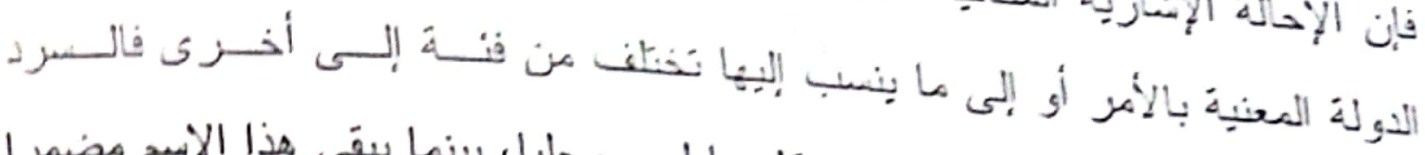

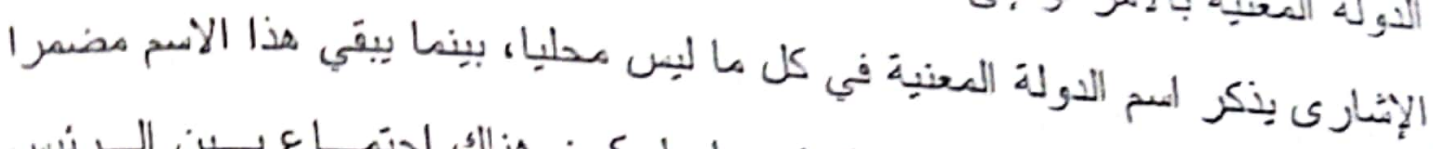

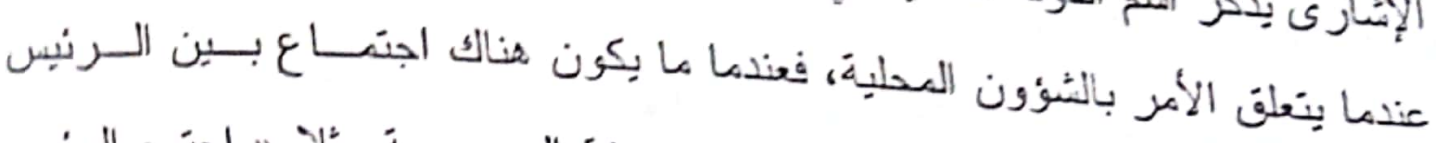

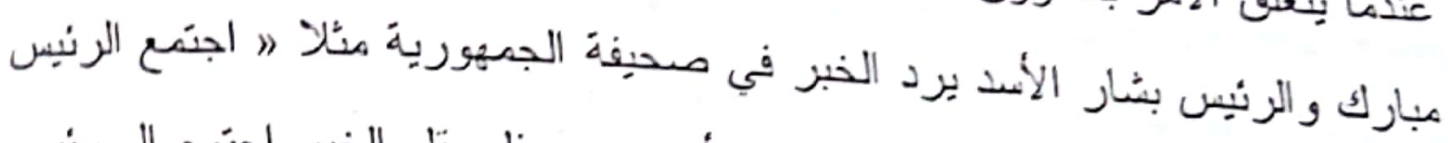

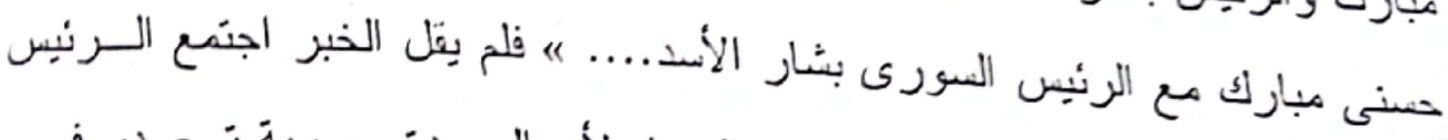

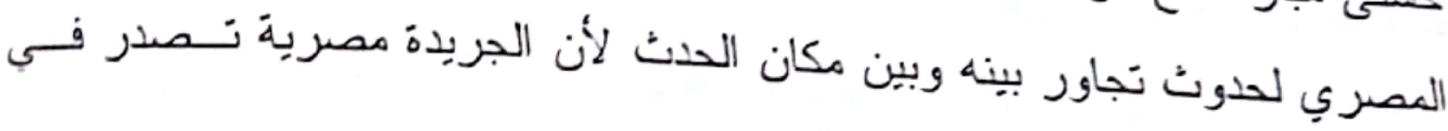

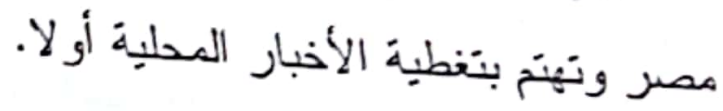

وغالبا ما بفترض الكاتب معرفة القارئ بكثير من المعلومات المتتوعة من

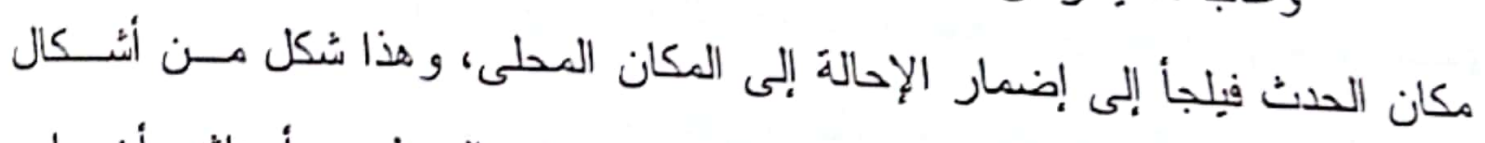

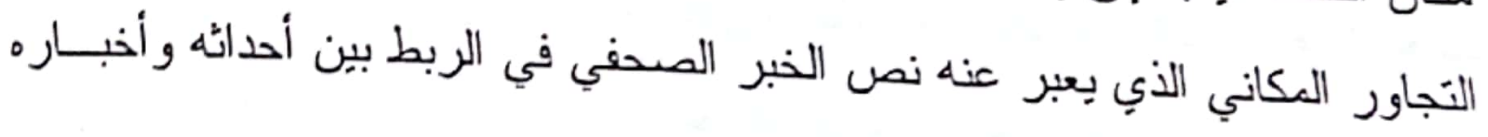

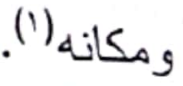

ونقدم أمنلة على ما سبق فيما يلى:

- نص بعنوان عمر سليمان يبحث مع شاورن استمر ار التهينة مع الفلسطينيين الجملة الأولى في النص: التقى أمس الوزير عمر سـلِيمان بــرئيس الــوزراء

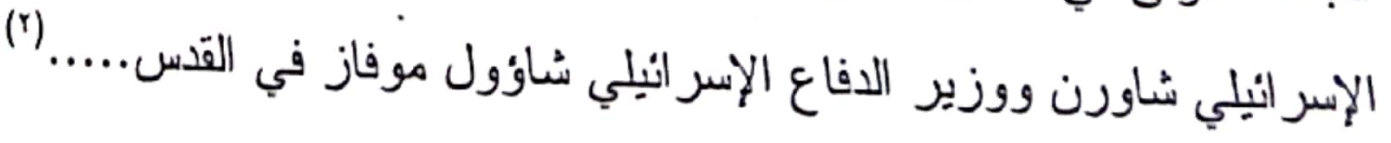

$$
\begin{aligned}
& \text { (1) انظر السابق ص1||-1Y. }
\end{aligned}
$$

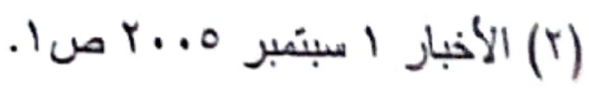


- في الجملة السابقة تم التعبير عن زمن النص ومكايه:

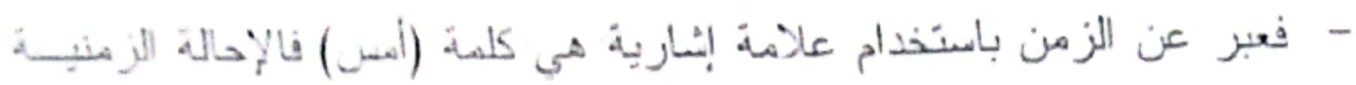

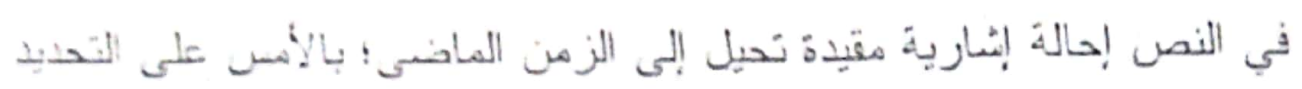

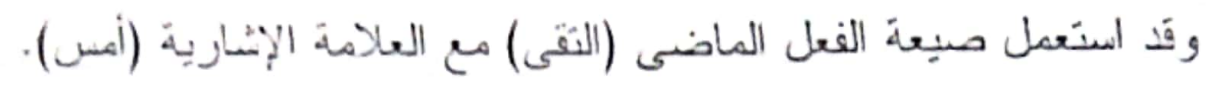
- كما عبر عن مكان الحدث في النص بذكر مكان اللفاءو وهى (فـــي الثـدس) وأيضا بنسبة أطر اف الحدث إلى دولهم " فاريل شارون الإسر ائيلي ووزير الدفاع الإسر ائيلي "ه ولم يقل الوزير عمر سليمان المصري لحذوث التجاور بينه وبين مكان الحدث لأن الجريدة التي نقلت الخبر هى جريــدة الأخبـــار

$$
\text { وهى مصرية وصدرت في أرض مصرية. }
$$

- نص آخر بعنوان صرف أوراق طلاب المرحلة الثالثة والأخيرة بحد أدنـي

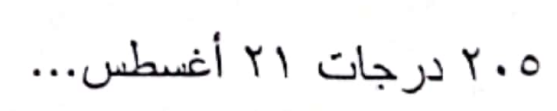

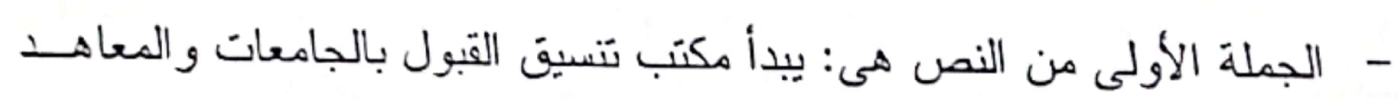
من اب أغسطس الحالى صرف أوراق طلاب المرحلة الثالثـة و الأخيــرة

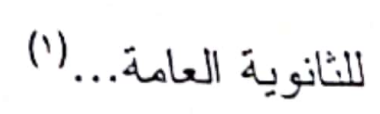

عبر عن زمن النص السابق باستخدام صــيغة الفــلـل المــضار ع (يبـــأ) و العلامة الإشارية وهى (اr أغسطس) و الإحالة الزمنية في النص هى إحالة إشارية

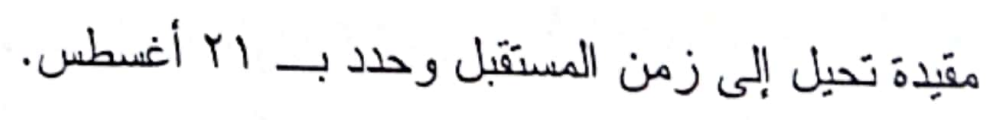
ولم يتم التعبير عن مكان الحدث في الجملة السابقة بل الإحالة المكانية هنا مضمرة، وقد اعتمد الكاتب هنا على معرفة القارئ بمكتب تتسيق القبول بالجامعات و المعاهد، كما أن التجاور المكاني بين الخبر والحدث الذى بنقل النص وبين مكــان

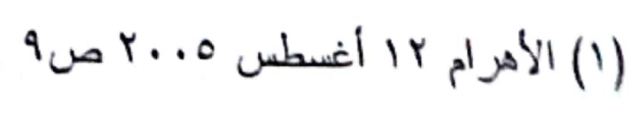




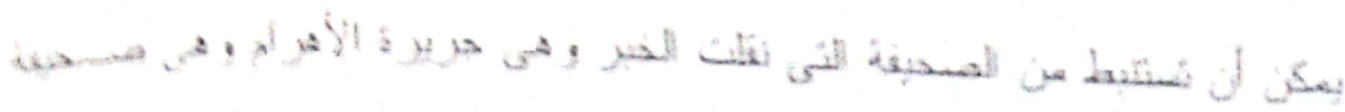

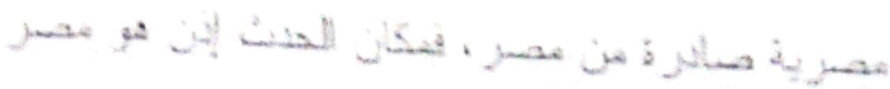

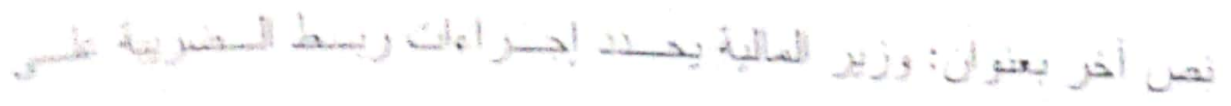

(1)... المز نبات

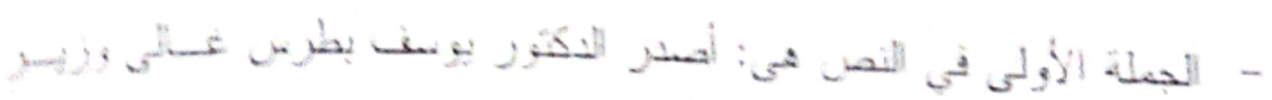

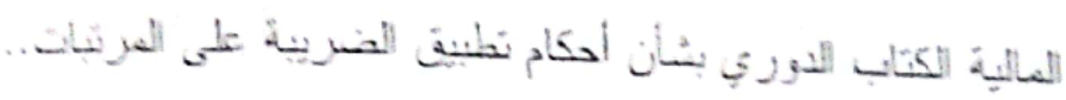

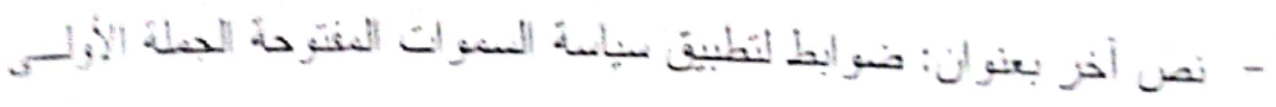

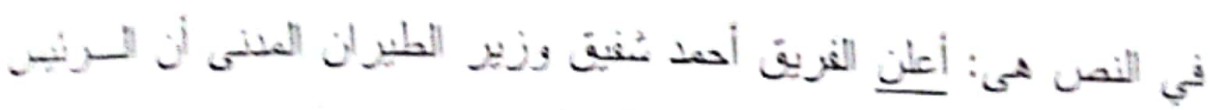

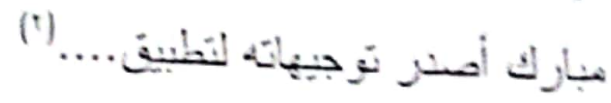

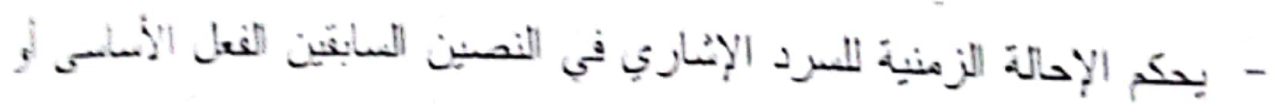

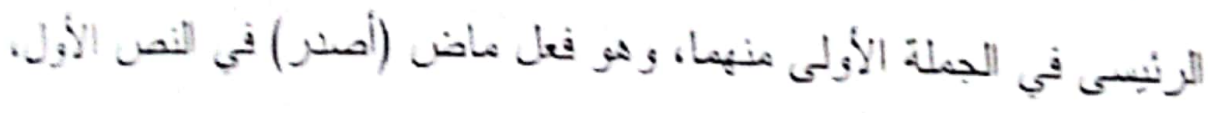

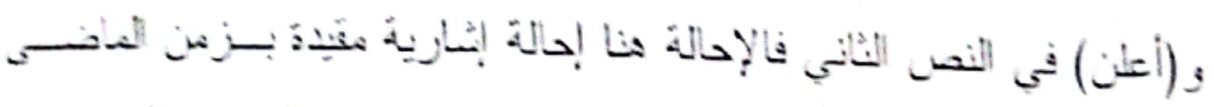

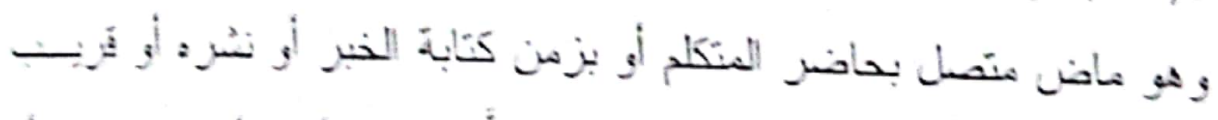

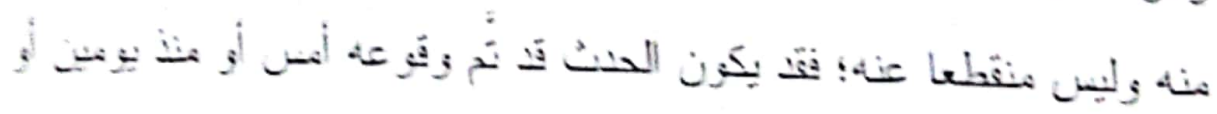

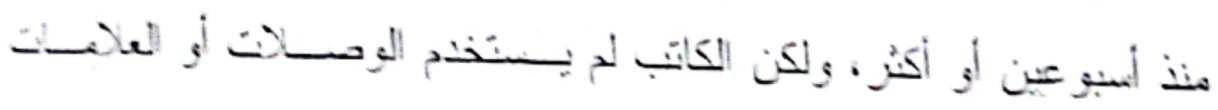

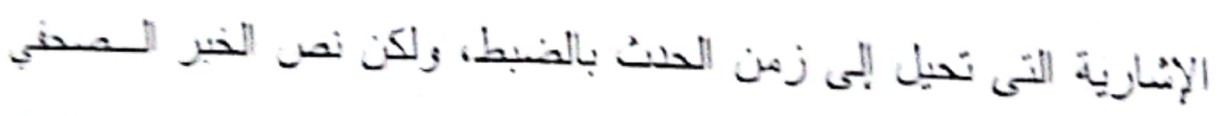

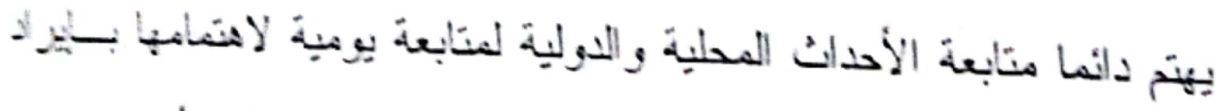

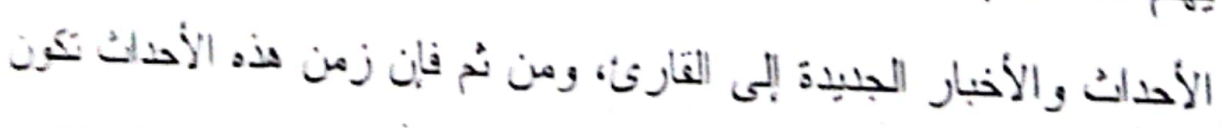

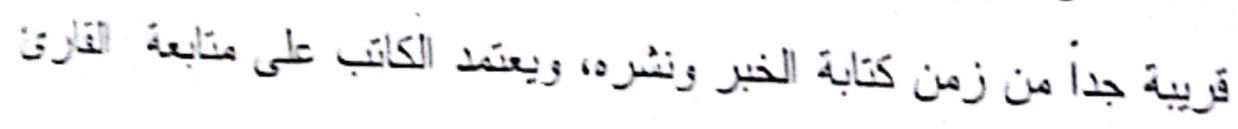

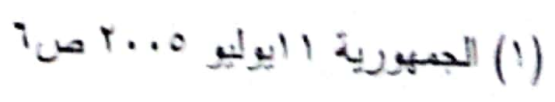

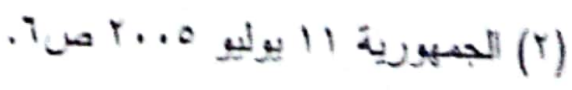




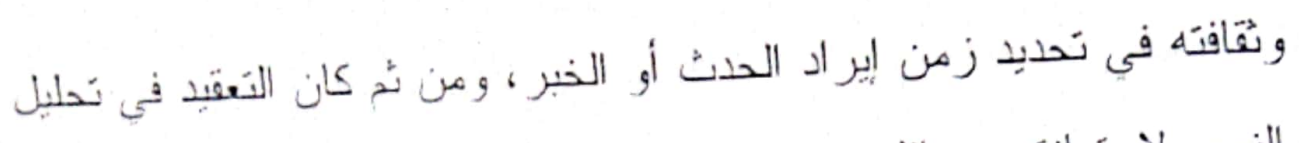

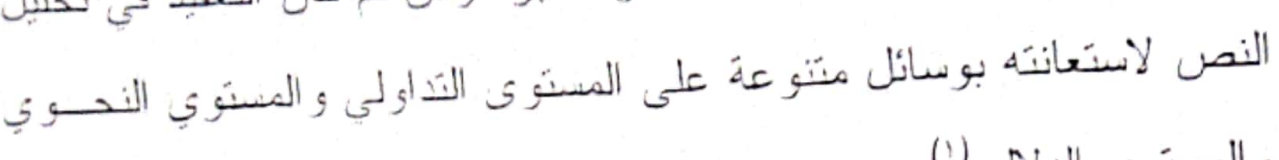
و المسنَّي الالاكي (')

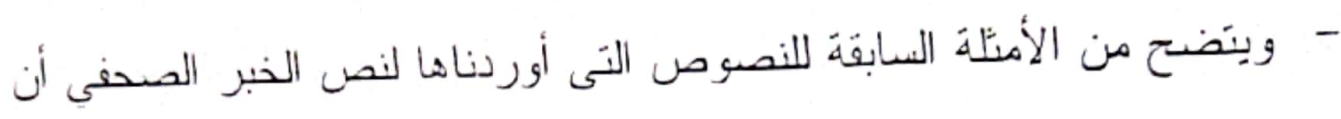

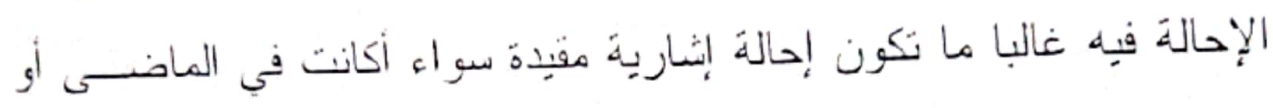

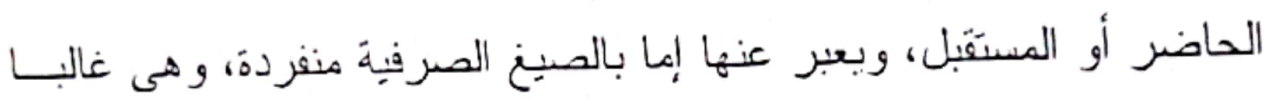

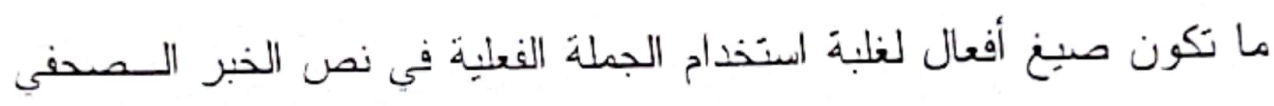

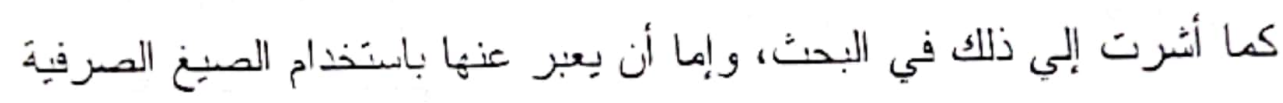

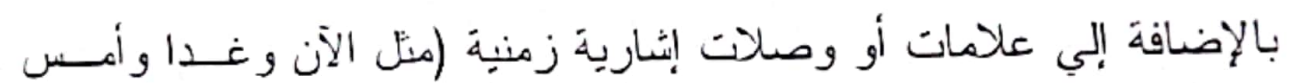
وصباح أمس ونهاية هذا العام...إلخ وهي التي تحدد جهة الإحالة الزمنية. ب- r: التر ابط الزمني و المكاني بين أجزاء نص الخبر الصحفي: لا أريد

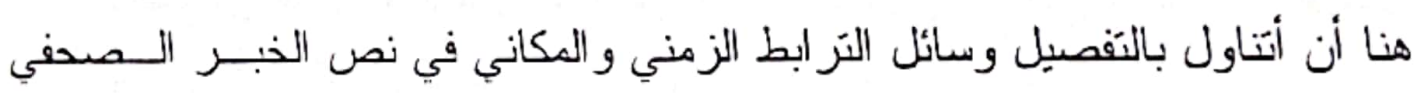

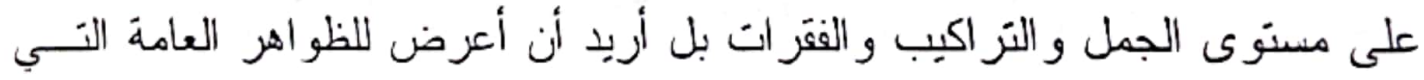
بكثر الاعتماد عليها في هذا النوع من الربط والني نعطي لنص الخبـر الـصحفي

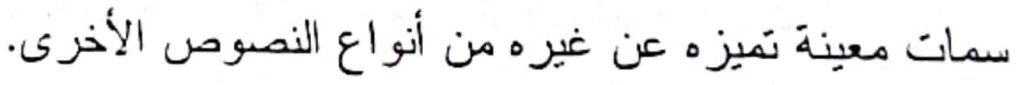

فمن الظواهر التي يُشيع استخدامها في نص الخبر الصحفي شيوع استعمال عبار ات إبشاربة زمنية أو مكانية تؤدي دور الربط بين الجمل والتراكيب وكنلك بين الفقر ات وتعمل على تر ابط النص وتماسكه. 


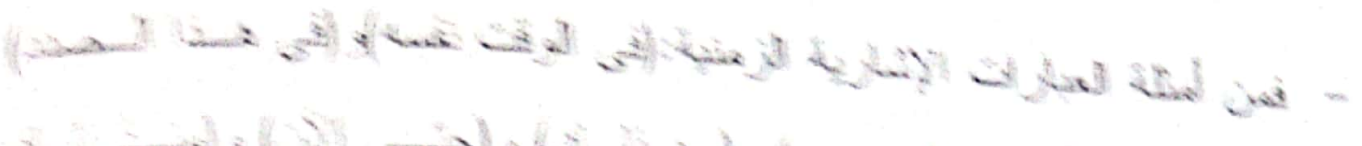

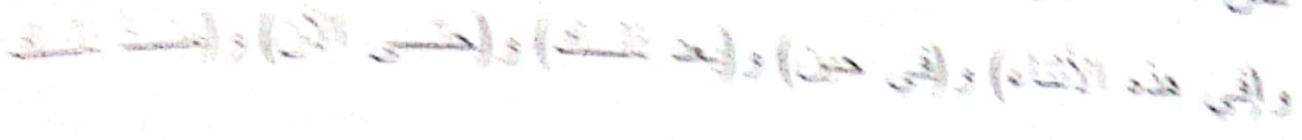

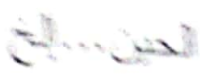

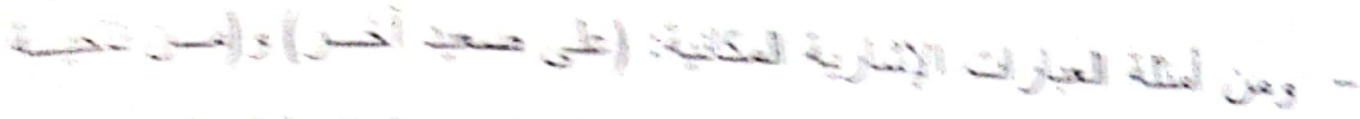

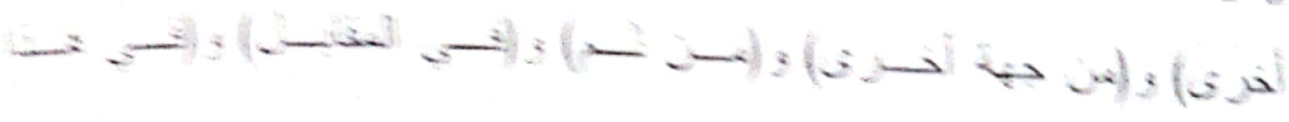
$-2 \cdots(2+6)$

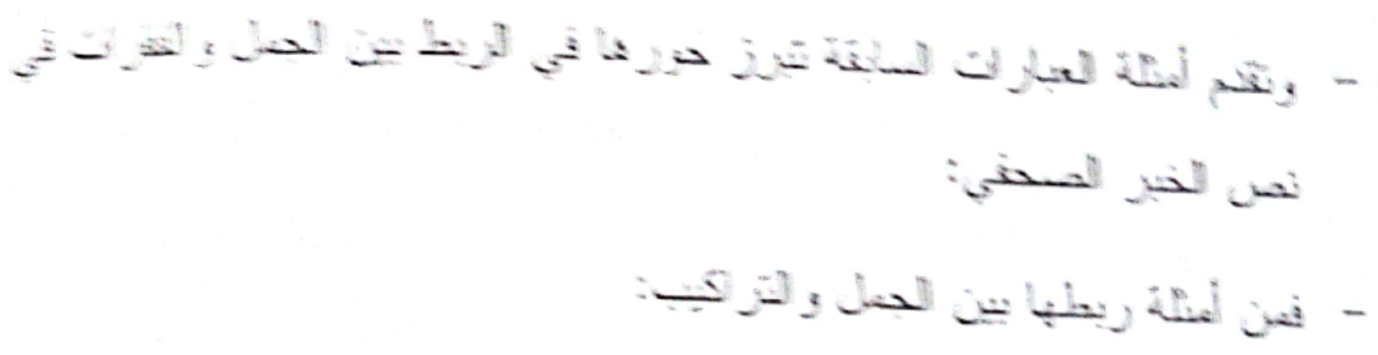

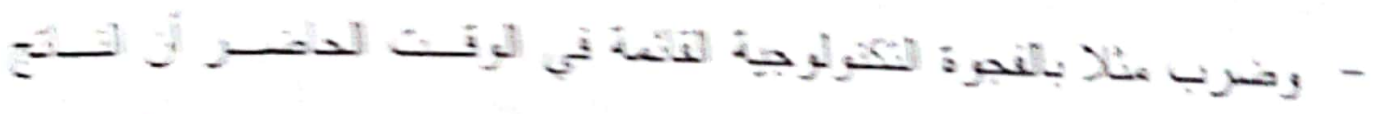

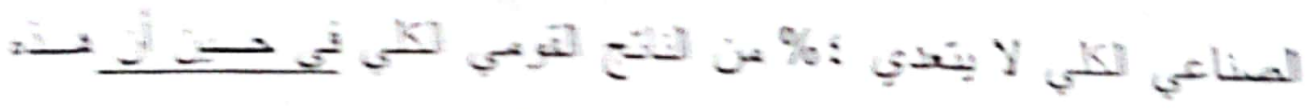

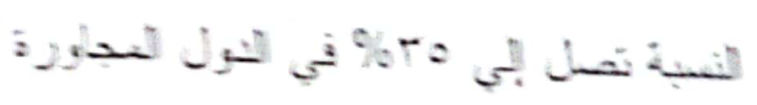

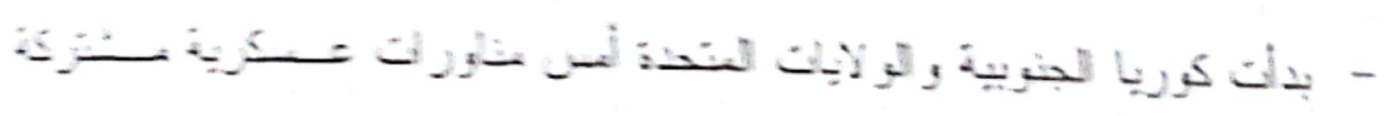

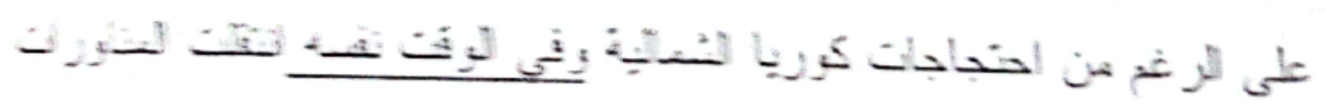
(9)

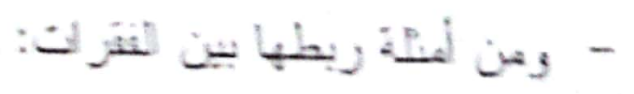
(7) -

$$
\begin{aligned}
& \text { IV a r.o }
\end{aligned}
$$

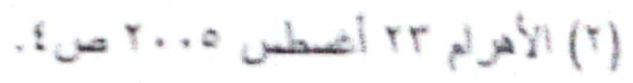

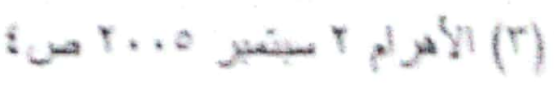




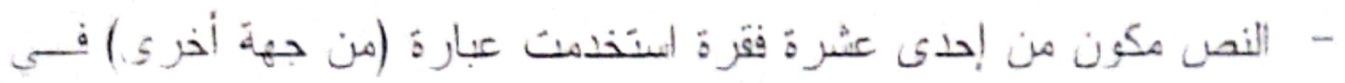

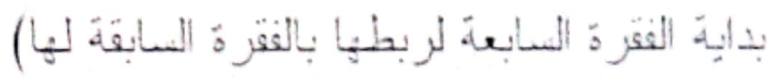

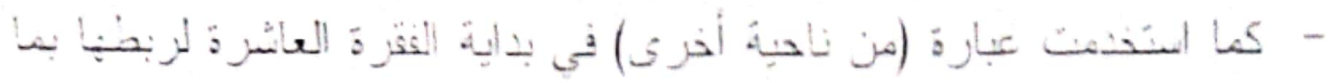

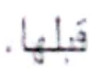

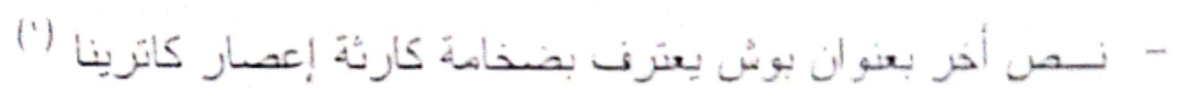

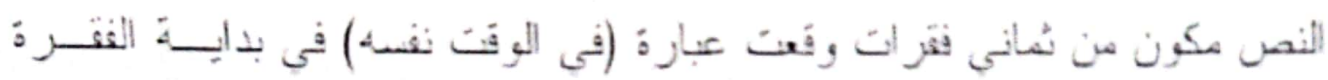

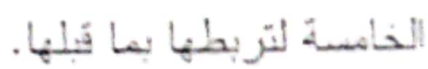

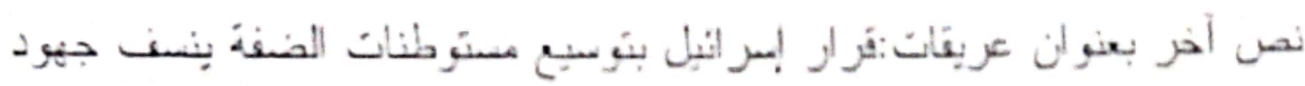

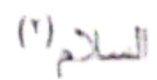

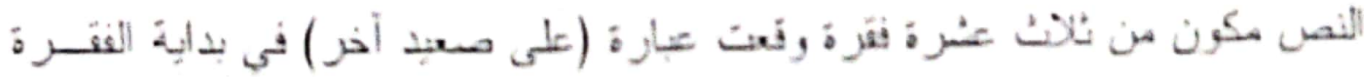

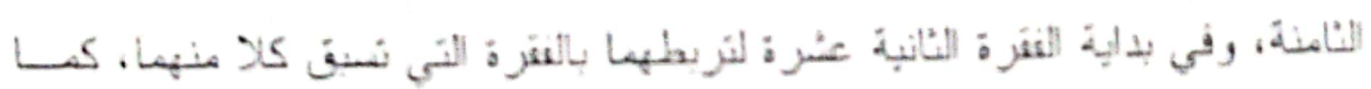

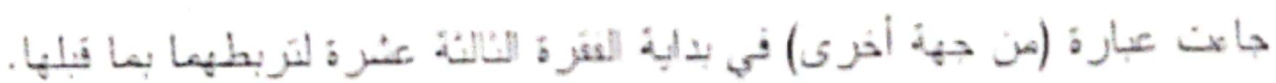

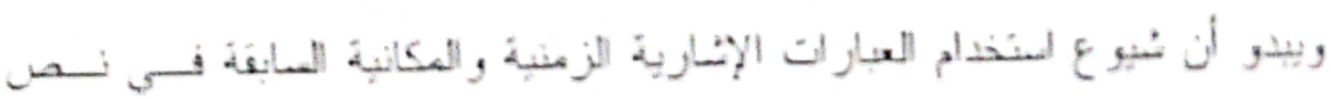

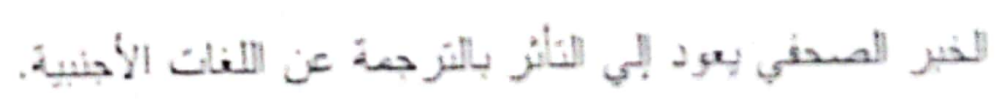

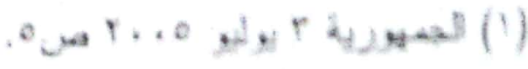

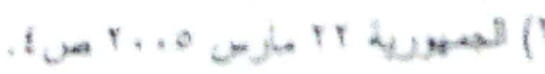




\section{الهينت المبن}

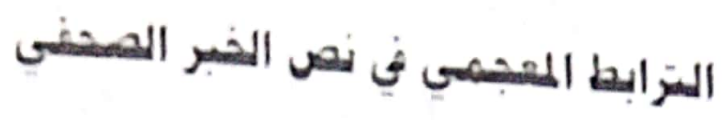

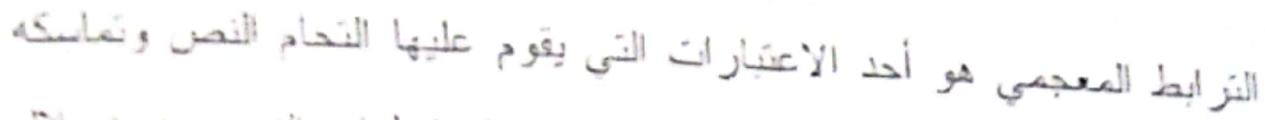

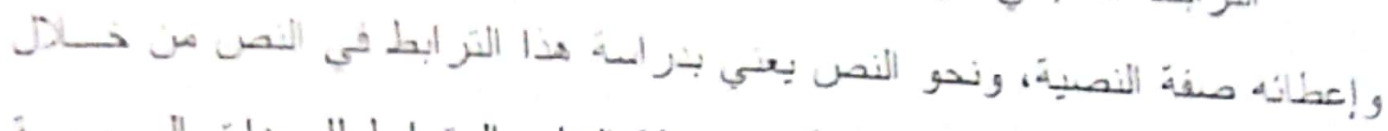

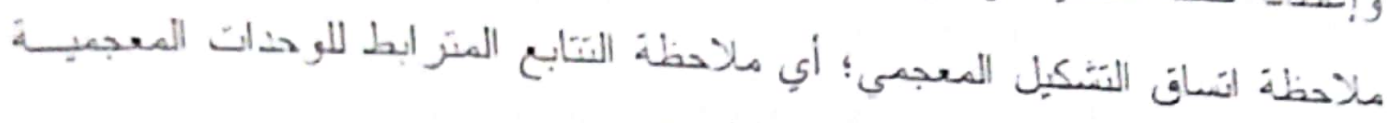

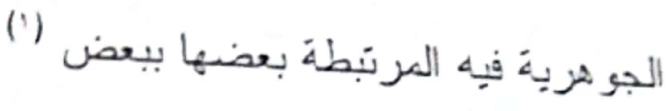

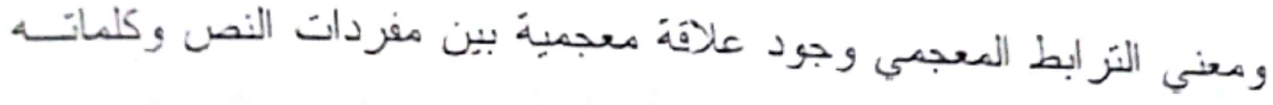

التي تتضافر فيما بينها الخدمة لموضو ع الرنيسي في هذا النص.

وينقسم الاتساق المعجمي إلي قَمين:

الأول الاتساق المعجمي التكراري ويعرن بأنه إعادة عن صر معجمسي أو

مر ادفه أو شبيهه أو عنصر عام يشمله.

الثناني الاتساق المعجي التضامي ويعرن بأنه ارتباط مجمو عة من الكلمات

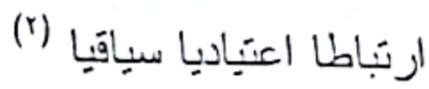

وبعبر عن الارتباط السيِّي الاعنبادي بين مجهو عة من الكلمات بمـصطلح

آخر يسمى "المصاحبة " collocation التى تعنى المصاحبة الاعتبادية لكلمة بكلمات

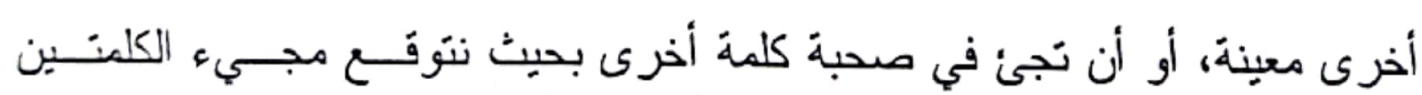

منصاحبتين في العادة) (r)

(1) انظر فولفجانج هاينه مان وآخرون:مدخل إلي علم لغة النص ص .r.

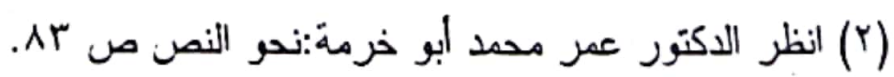

(r) انظر الدكتور محمد حسن عبد العزيز : المصاحبة في التعبير اللغوي صن 17. 


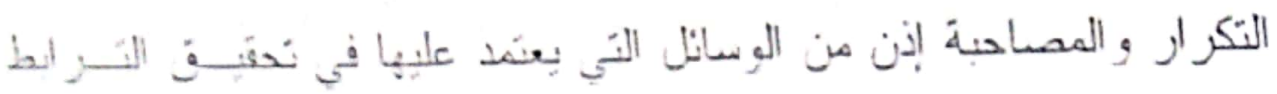

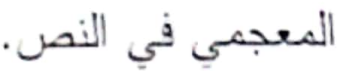

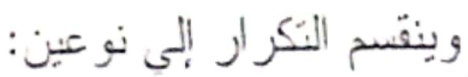

الأول: التكرار اللفظب الثاني:التكرار المنوي

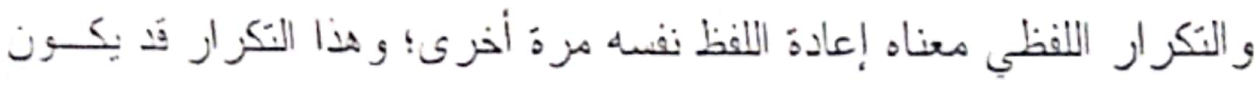

تكرار محضا أو تكرارا جزئنا، والنكرار المصض هو إعادة العنصز العجمى ننسه

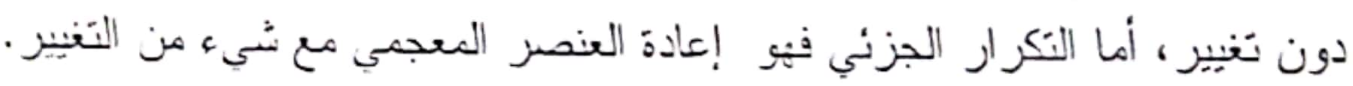

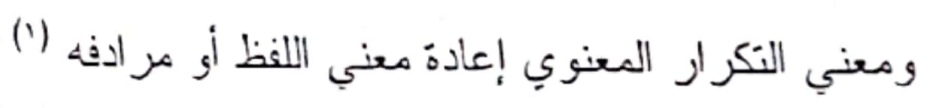

و الناظر إلي نص الخبر الصدفي يجد النكرار اللفظي بأنكاله الوسبلة الأولي والأساسية التي بعنمد عليها في تحقيق الترابط المعمي بين أجزائه.

ويقوم التزرابط المبجمي في نص الذبر الصدفي على أساس وجود نَركيّبـ

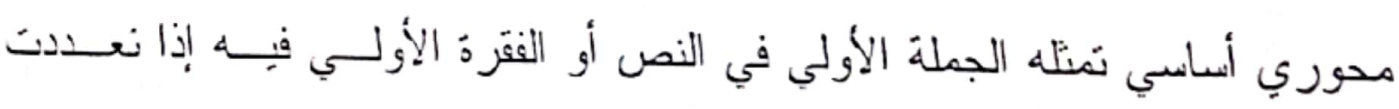

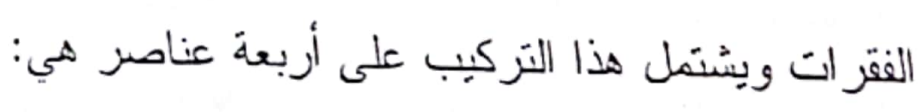
الحدث و أطرن الحدث أو المشاركون فيه وزمن الحثث ومكانه. ويمثل الحدث الفكرة الرئيسة أو الموضو ع اتزئيسي في الـنص ونتبـدو

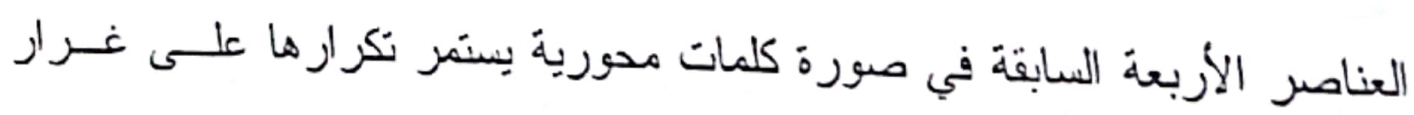
النص كله فتؤدي إلي تز ابطه معجميا.

(1) انظل الدكتور سعد مصلوح نحو أجرومية للنص الشعري ص 10\%. 


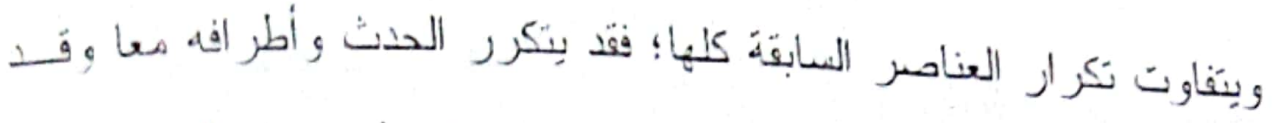

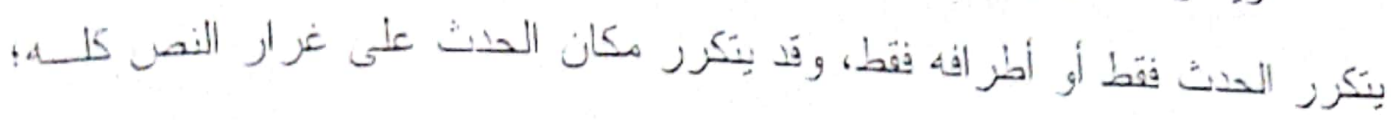

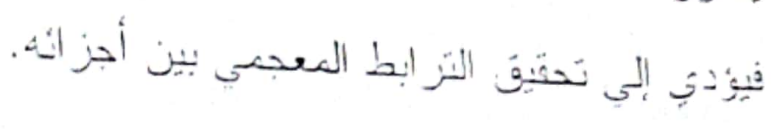
ونقام أهتله على ما سبق فيما يلي:

1- نص بعنو ان:الرئيس بفتَّح كوبري سو هاج الجديا خـلال (سبـاعات -

الكربر طوله مر V كبل بتكلفة مائة مليون جنيه. - النص مكون من ست فقرات هي:

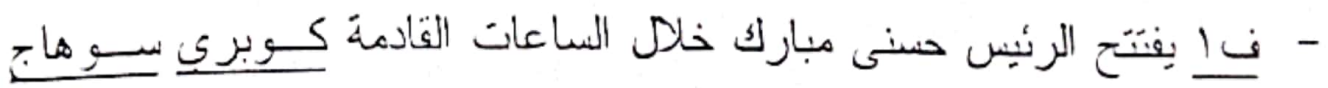
العلوي على النبل بإجمالي تكلفة تَلغ ندو مانَة مليون جنيه بطولِ يبلغ سبعة

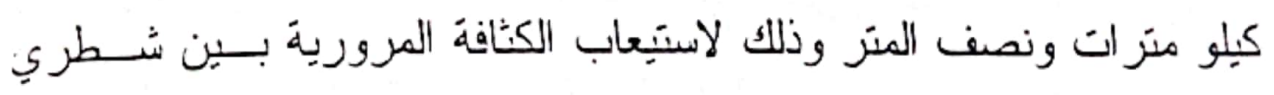
المدينة خاصة بعد زبادة الاستبعاب العمر اني من الجهة الشرقيَ.

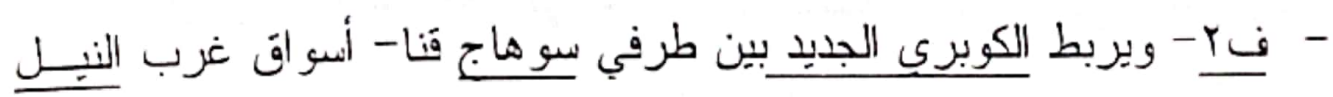

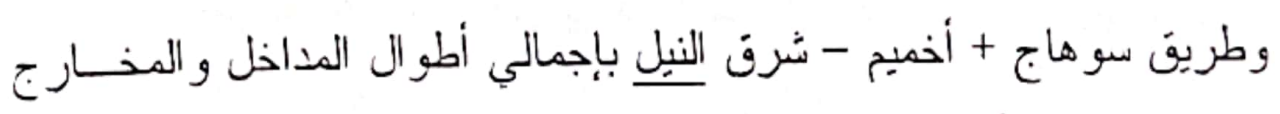

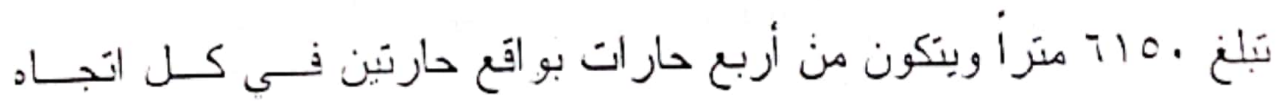

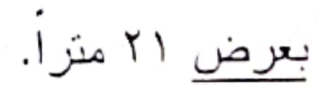

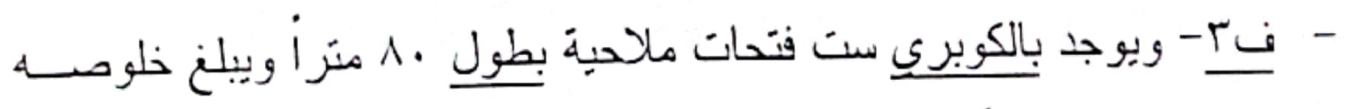

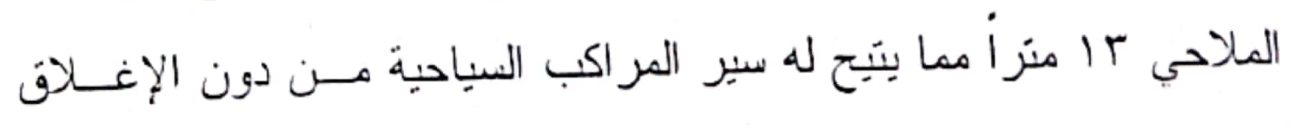

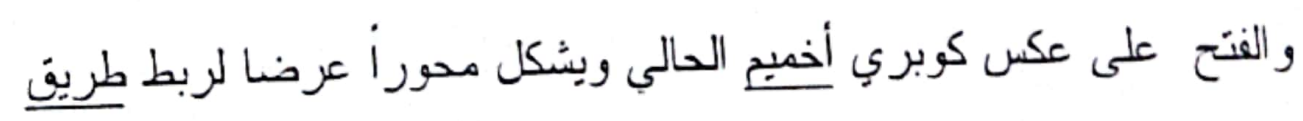
سوهاجو وَنا الزر اعي بغرب النبل بطريق سو هاج. نـ - كما بعد كوبري سوهاج الجديد حلا لمشكلة المرور نظر"ا لأن كوبري أخمِِِ

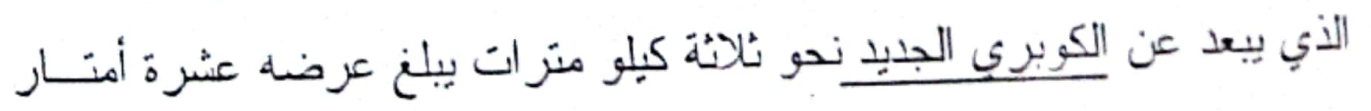




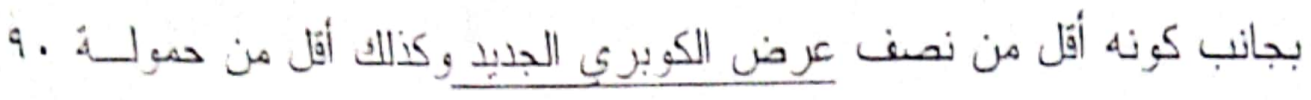

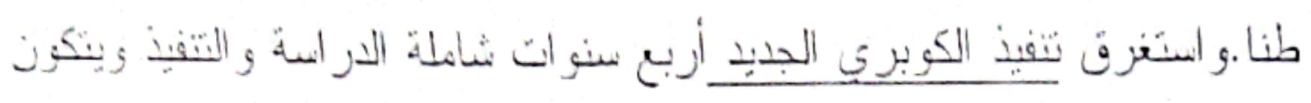

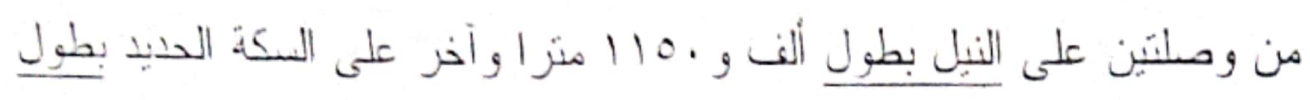

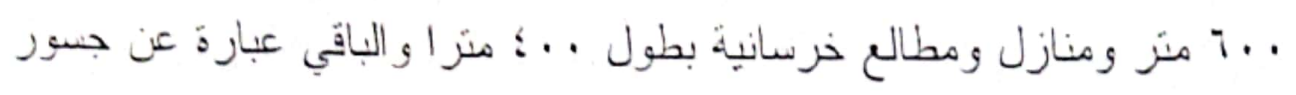

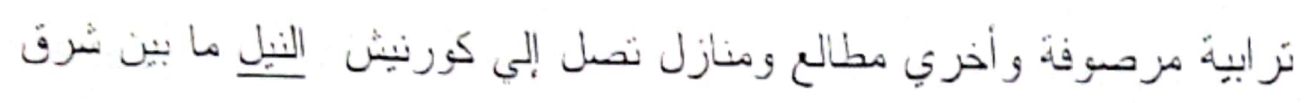

$$
\text { وغرب مننية سو هاج. }
$$

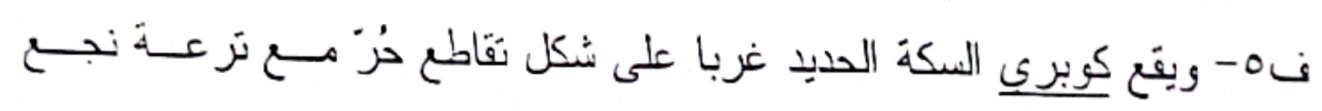

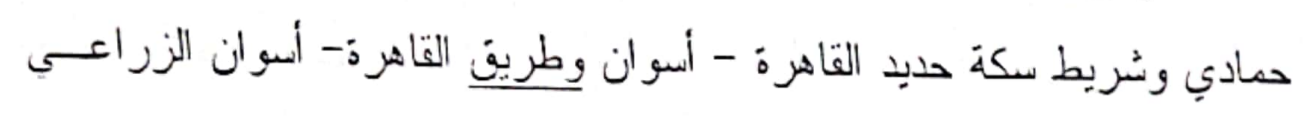

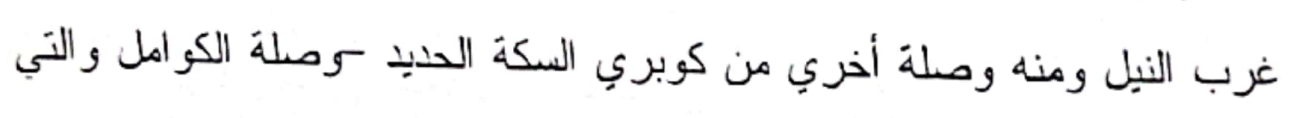

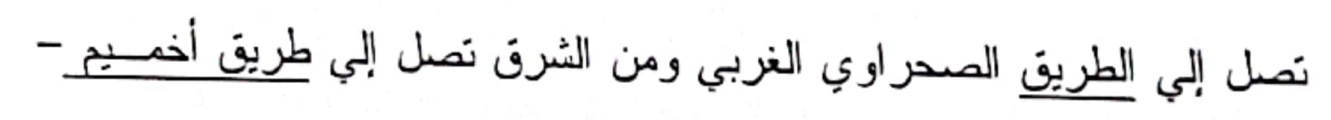

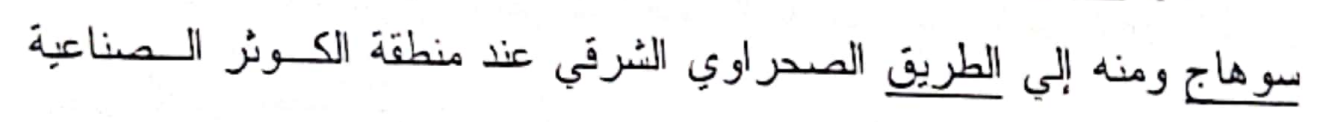
والو اقعة عند بدابة طريق سوهاج -البحر الأحمر الجنيل نح- وبعتبر هذا المحور نقلة تتموية من غرب النيل إلي الطريق الساحلي الدولي

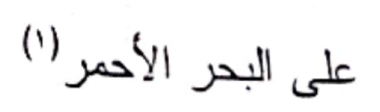
في النص السابق بمثل الحدث الرئيسي افنَّاح الــرئيس مبــارك كـوبري

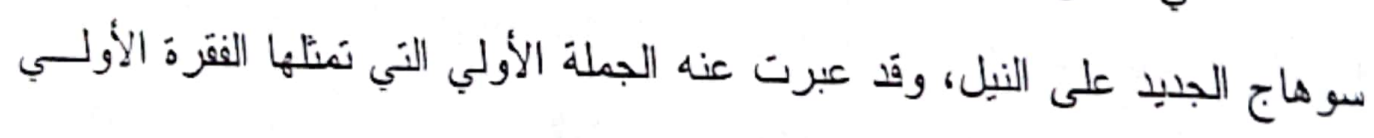

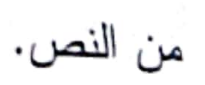

$$
\text { ومكان الحدث في النص هو سوهاج. }
$$

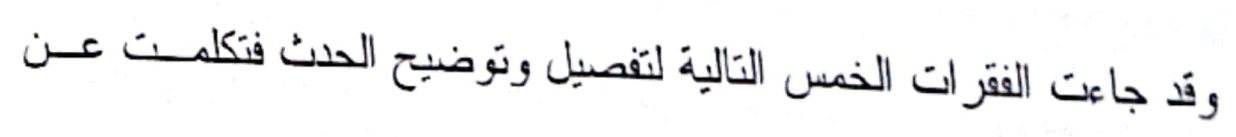
اهمبة الكوبري، ومحاوره المختلفة.

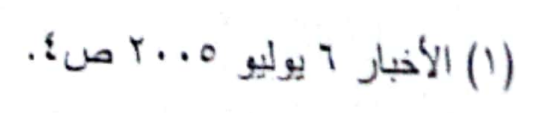




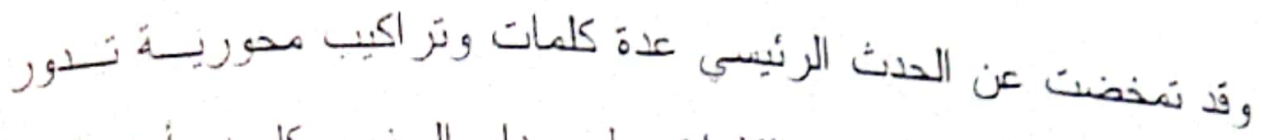

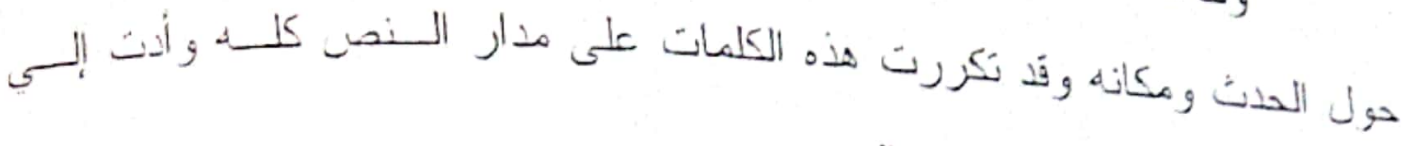

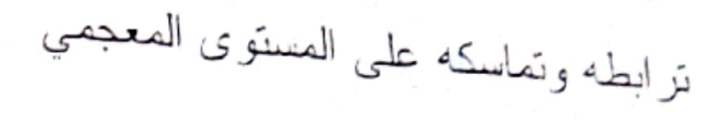

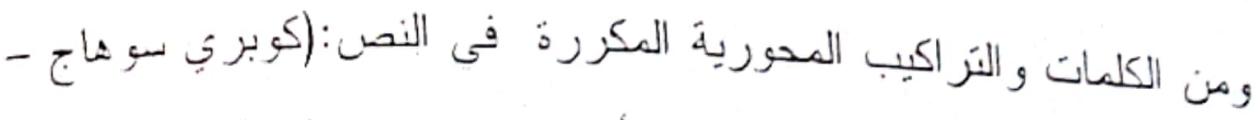

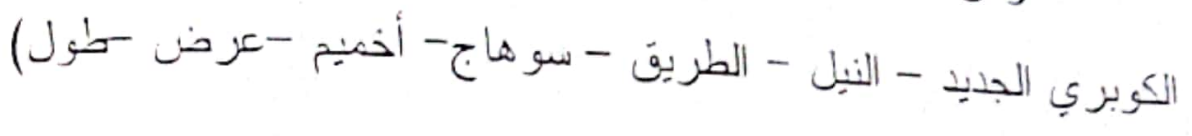

و الملاحظ في تكر ار عبارة (كوبري سوهاج) أنها قد تتكرر كلها في صورة

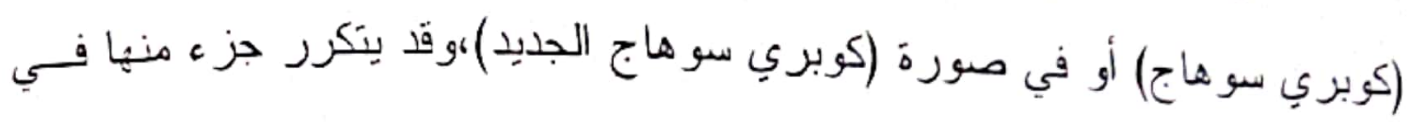

$$
\text { صورة (الكوبر الجديد). }
$$

$$
\text { أو في صورة كلمة واحدة فقط هي (الكوبري) }
$$

ومن ثُ فالنكر ار اللفظي في بعض العبار ات المكررة في النص السابق فَـــ

$$
\text { يكون تكرارا محضا كليا أو تكرار جزئيا. }
$$

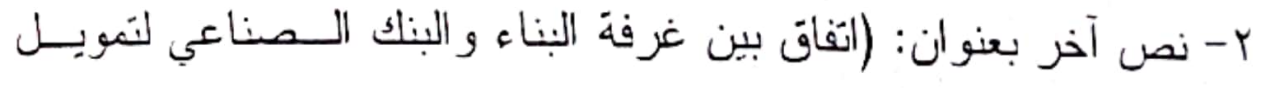

$$
\text { - - النص مكون من ست فقر ات هي: بقروض: ميسرة). }
$$

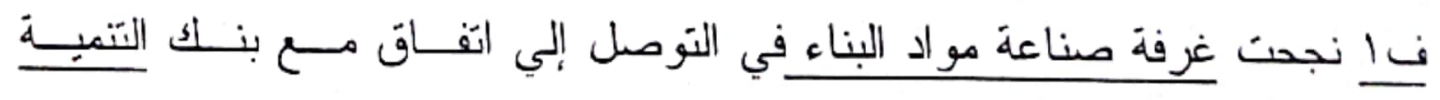

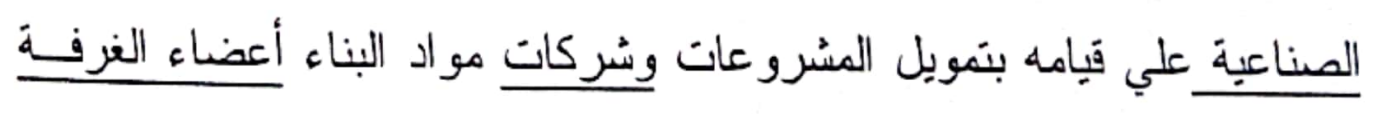

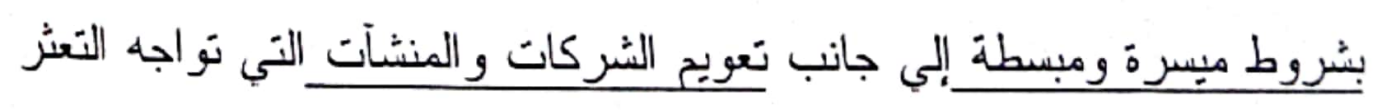
وأزمة في عمليات التشغيل في إطار خطة الغرفة للنهوض بقطاع مـو اد البنـاء

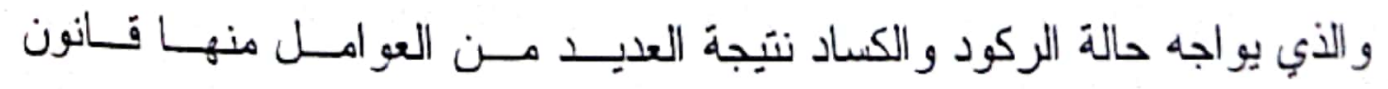

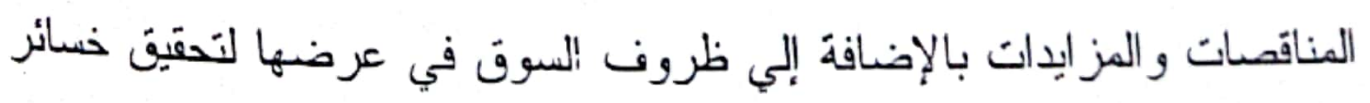




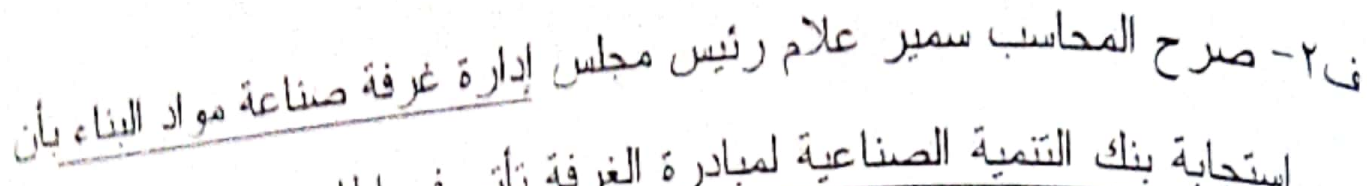

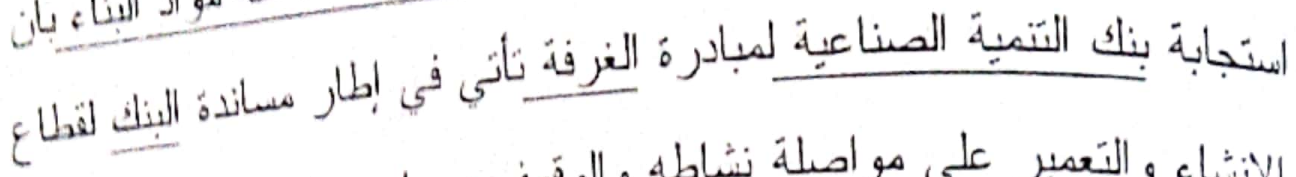

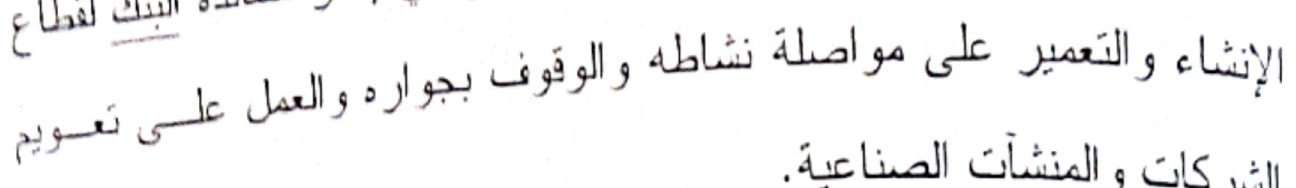

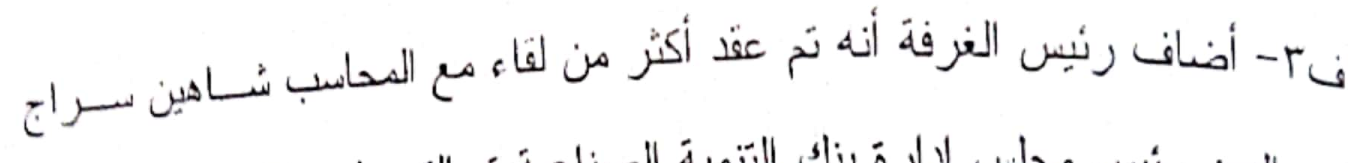

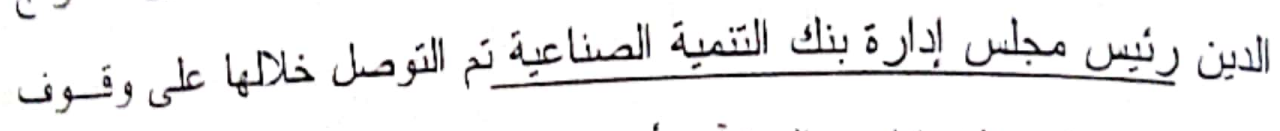

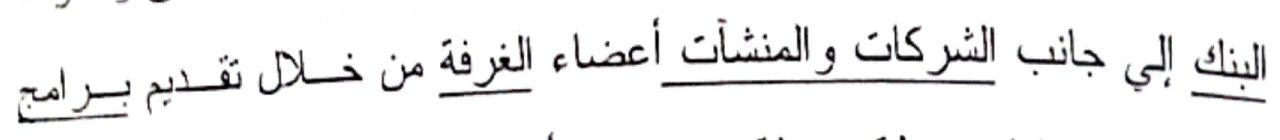

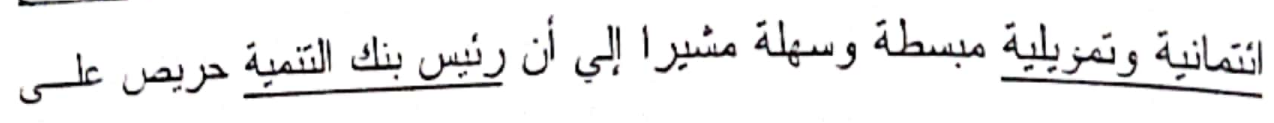
نجاح تجربته مع غرفة مو اد البناء لتكون بداية جيدة للنعامل مع بساقي النسرن الصناعِية الأخرى الني يو اجه أعضاؤها مثاكل تحويلية مع البنوك.

نـ - أوضح أن برنوكول التعاون الذي تم توفَعه مع البنك خله الأيام الماضـبـة سون بِاهم في حصول الأعضاء على التسويلات الأنمانبِة والتمويلية خـلال الفترة القادمة.

نه- و أكد المحاسب شاهين سر اج الدين رئيس بنك التنبة الصناعبة أن هناك فكرا جديدا يتم التعامل به في بنك التتمبية الصناعبة خلمل المرحلة القادة انطلقا من

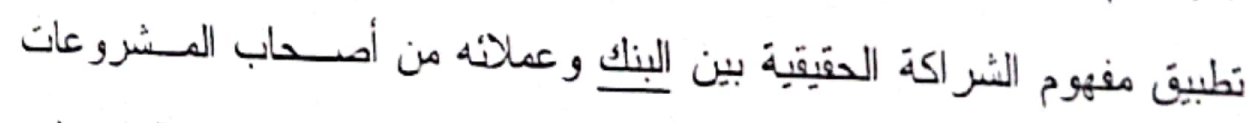
و الشركات المعمارية و الإنشائية ومساندته و الوقون بجو ارهم من خلا تـوفير

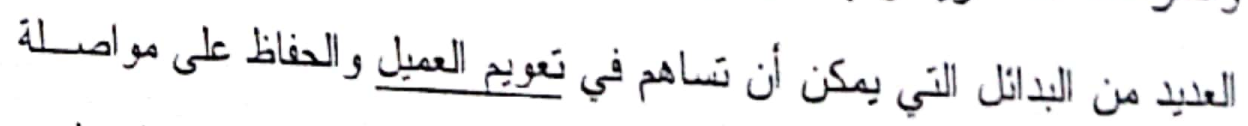

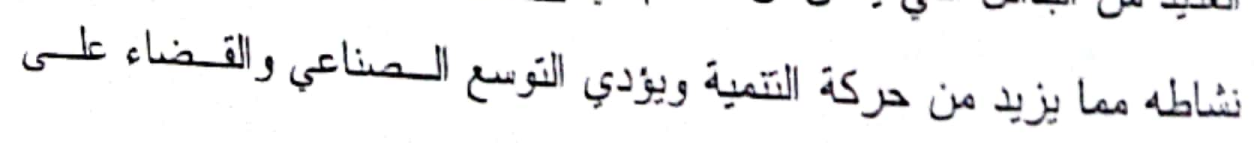
الانكماشُ

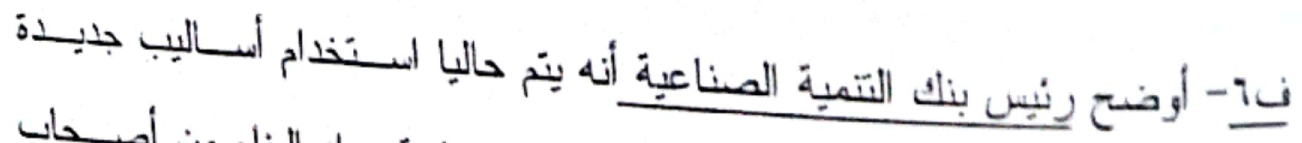

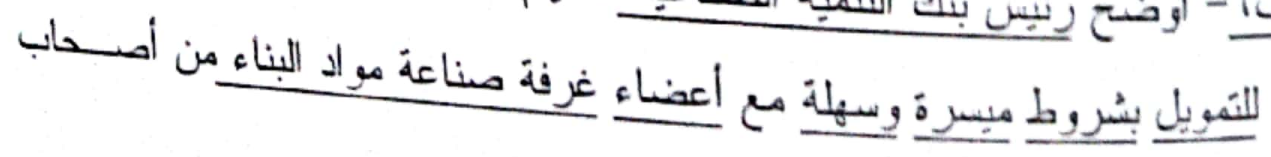




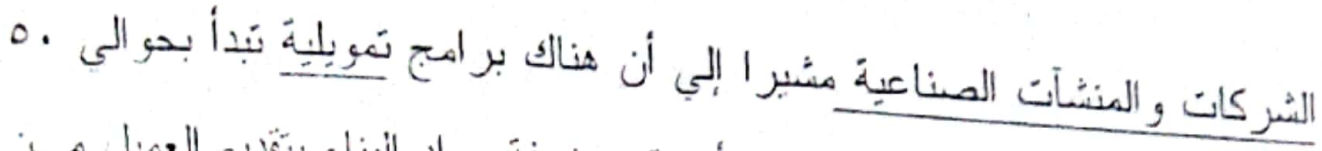

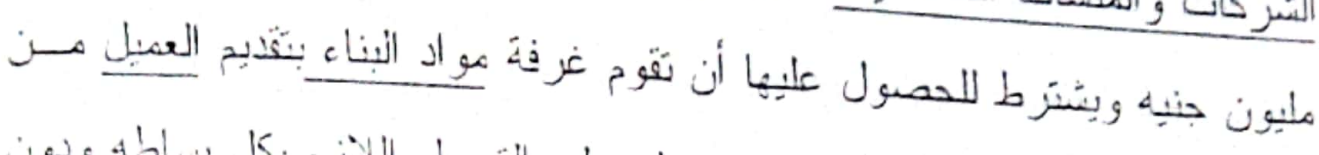

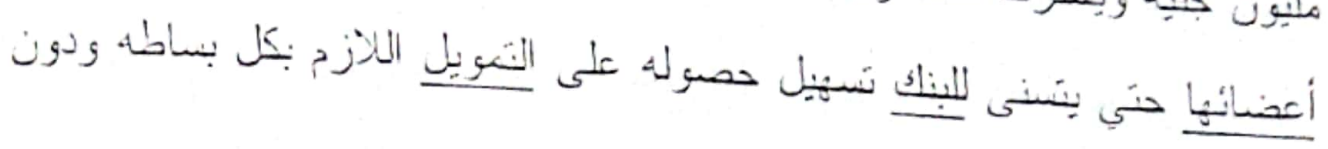

نَعَدِ

في النص السابق الحدث الرئيسي أو الفكرة الرئيسِة فيه هي: اتفاق غزفة

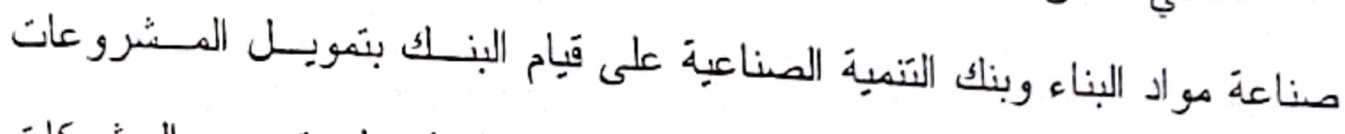

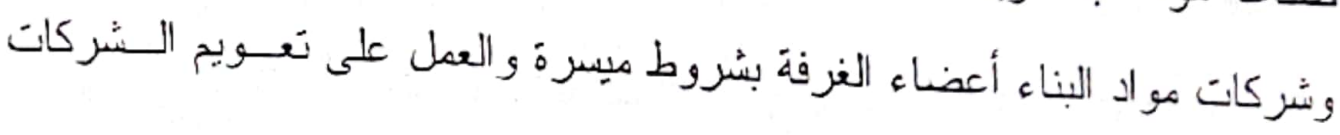
و المنشآت التي تو اجه النعُر. وقا جاء النعبير عن الددث أو الفكرة الرئيسية في النص في الجملة الأولي منه و التي تمتل الفقرة الأولي من النص. -ويمثل أطر اف الحدث في النص:أ- غرفة صناعة هو اد البناء ورئيسها بـمير علام ب- بنك التمية الصناعية ورئيسه المحاسب شاهين سراج الدين.

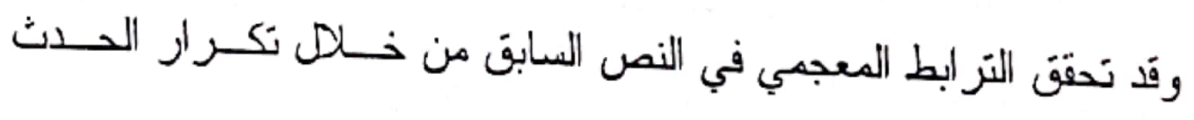
الرئيسي في النص و أطراف هذا الحدث على مدار لنص كله. وقد جاء نكر ار الدلث وأطر افه في النص كله في صورة كلمات وعبارات

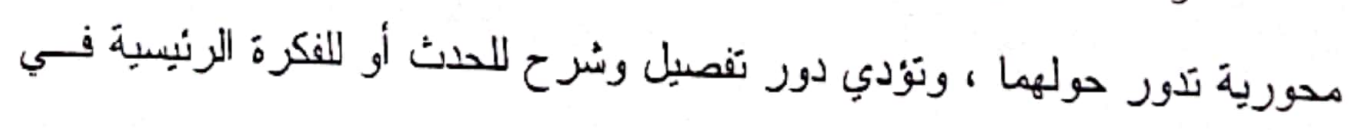
النص. - | - | فمن الكلمات والعبار ات المحورية المكررة في النص:غرفة صناعة مـواد

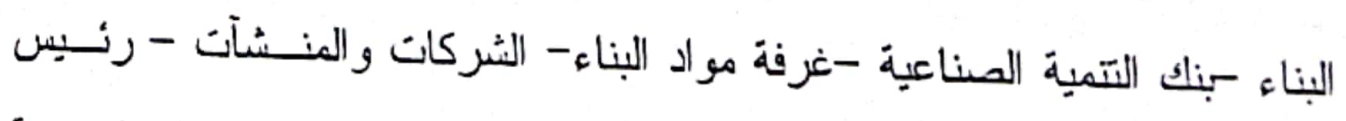

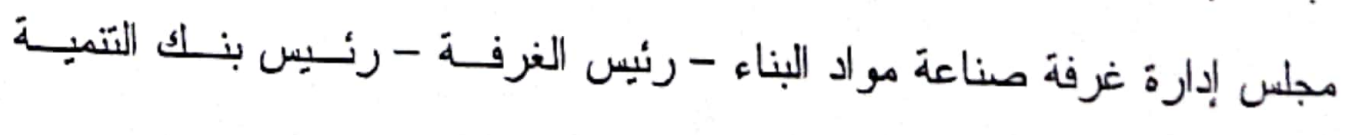




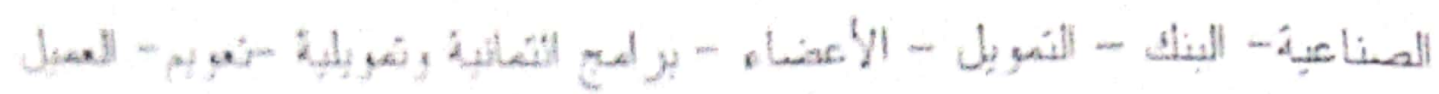

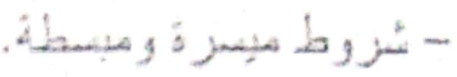

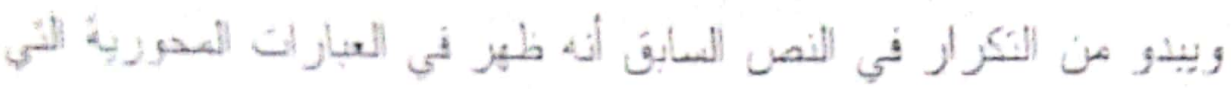

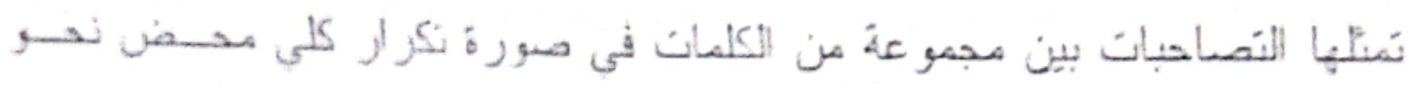

$$
\text { (رئشن مجلس إبارةً غرفة صناعة مو الد البناء). }
$$

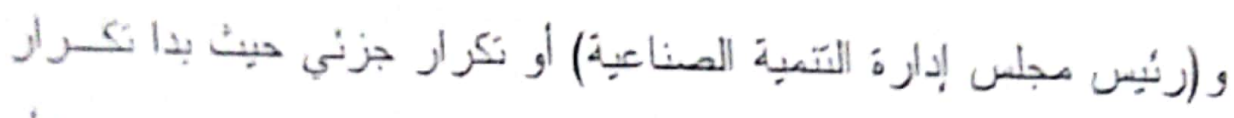

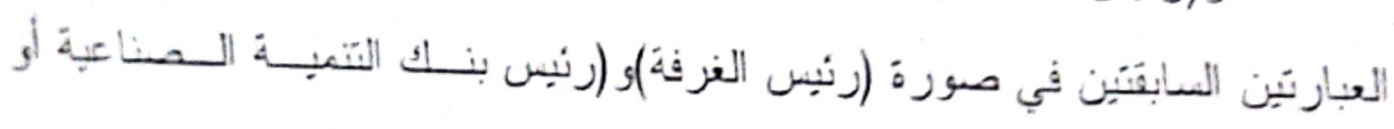
رئبس بنك التَبةة).

وقَ تكزرت عبارة رينِس بنك التمبة الصناعية) في النص في صورة كلدة

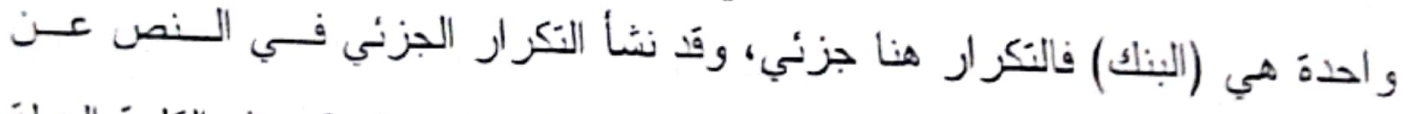

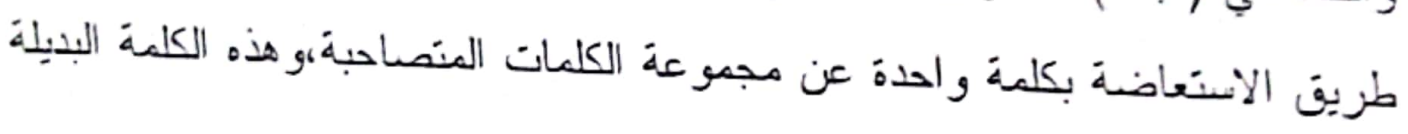

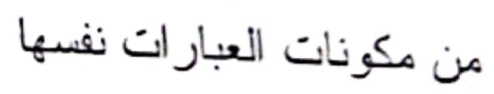

ويبذو أن التكرار اللفظي هو الأنسب لطبيعة الـسرد فــي نــص الذبـر

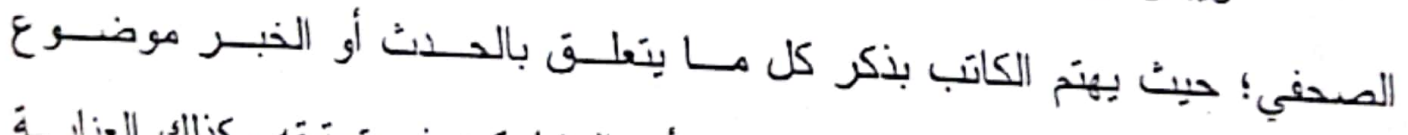

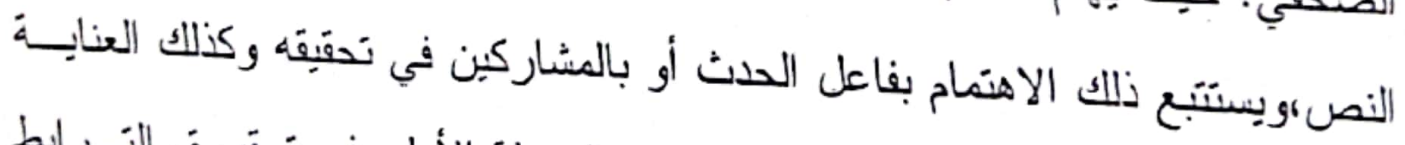

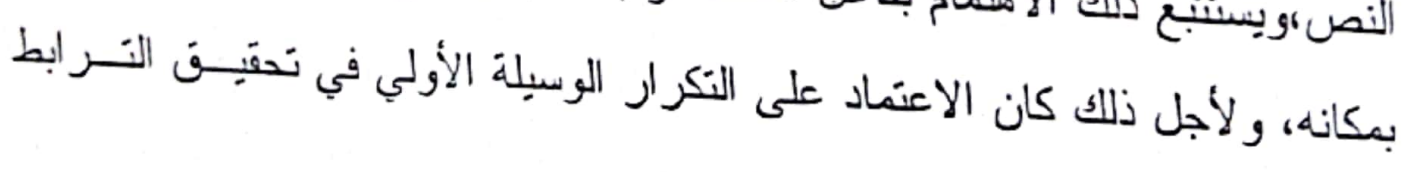
المجمي بين أجزاء نص الخبر الصحفي. -

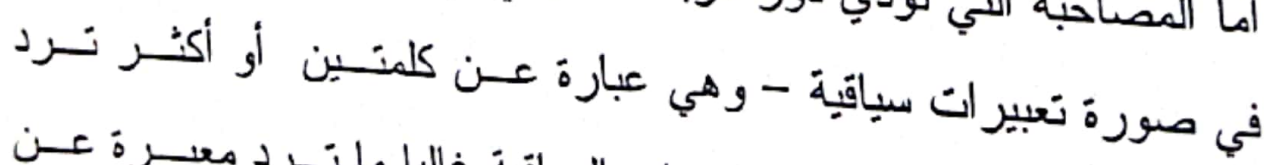

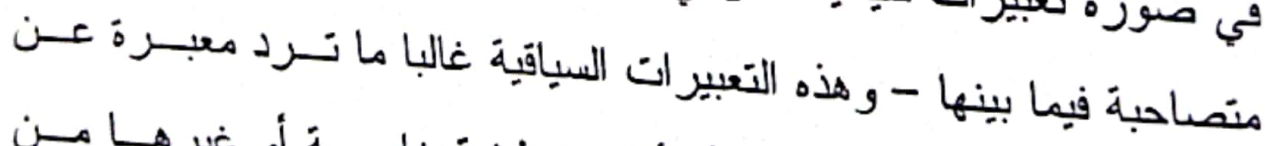

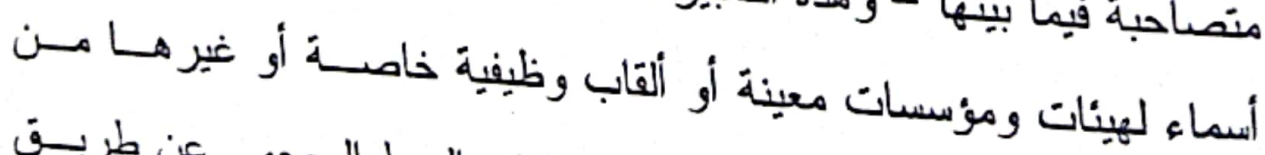

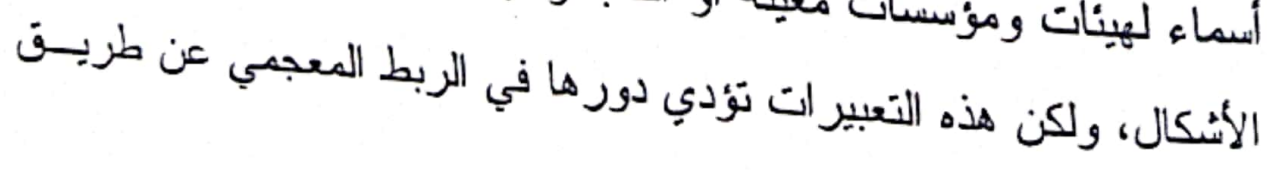




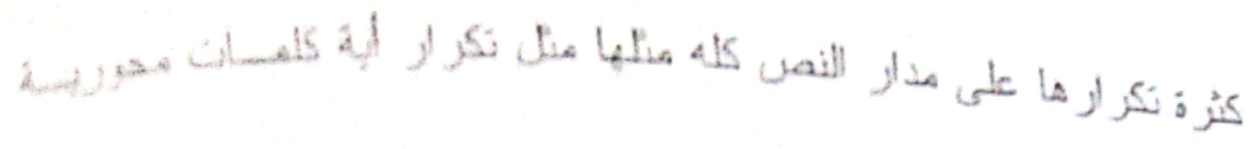

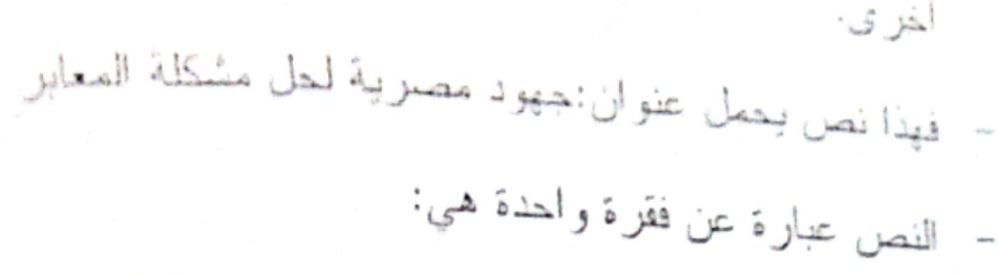

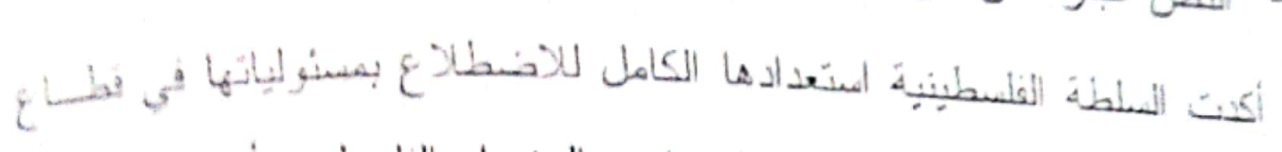

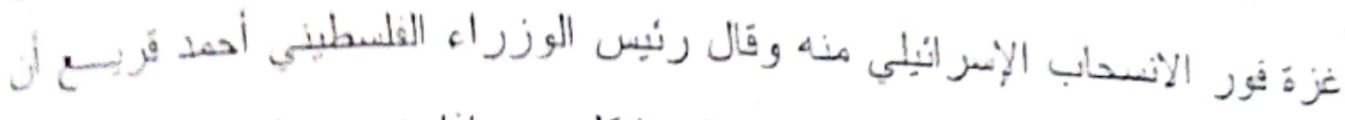

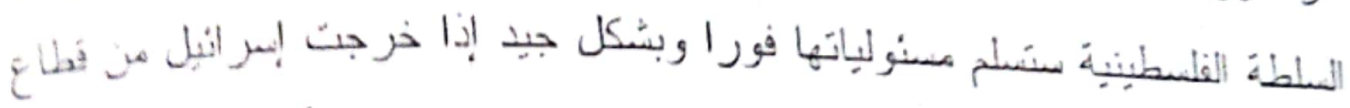

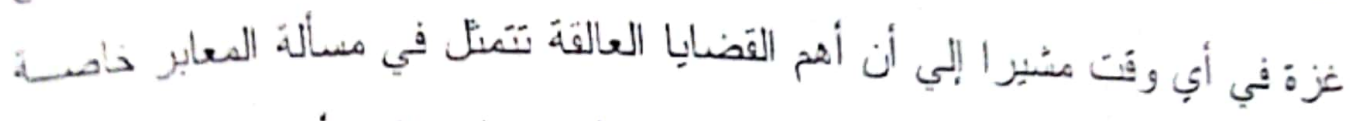

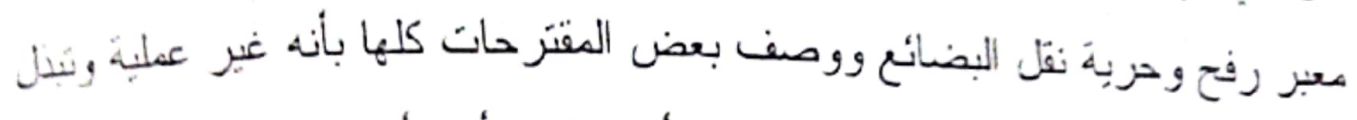

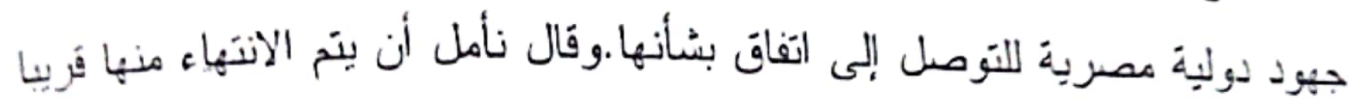

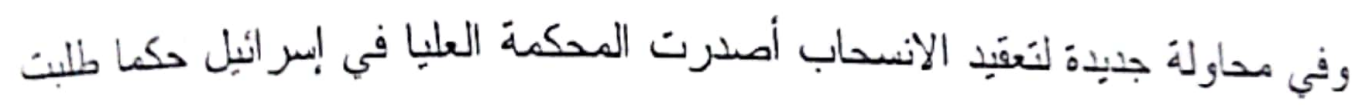

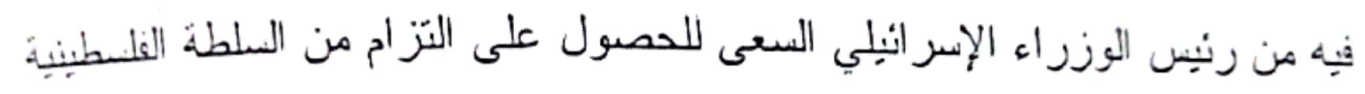

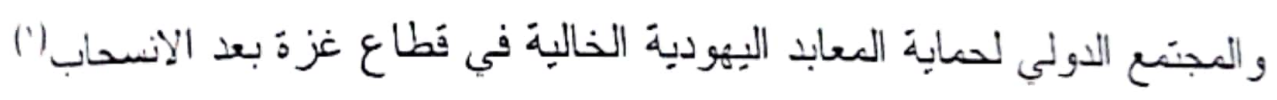

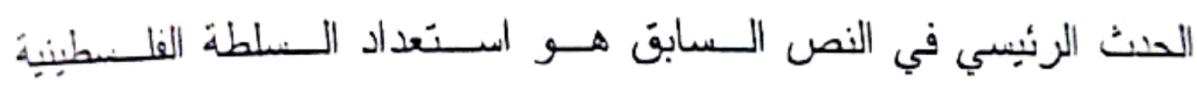

$$
\text { للاضطلاع بمسئولياتها في قطاع غزة بعد الانسحاب الإسر ائبلي. }
$$

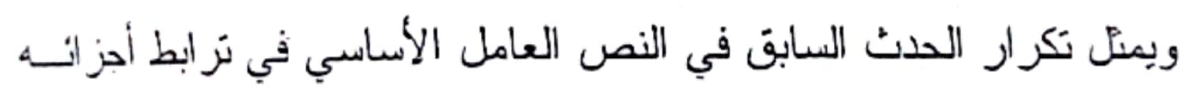

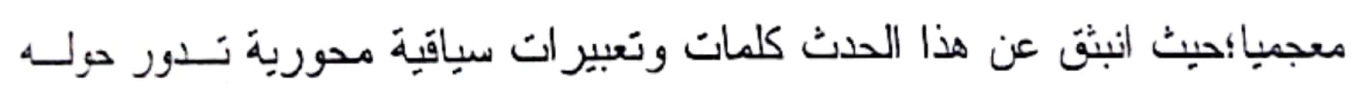
نوضحه وتفسره هي التي تكررت في النص كله، وأدت إلي تر ابطه، فمن الكلــات

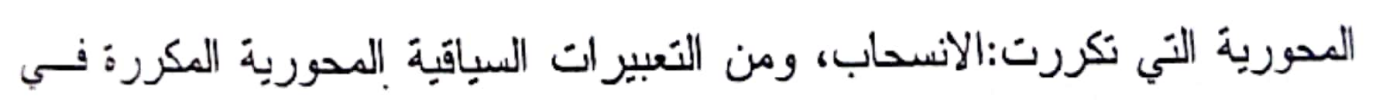
النص:السلطة الفلسطينية - فطاع غزةه- رئيس الوزر اء الفلسطيني - رئبس الوزراء

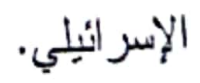

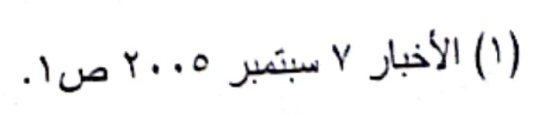




\section{البيحث الخاوسي}

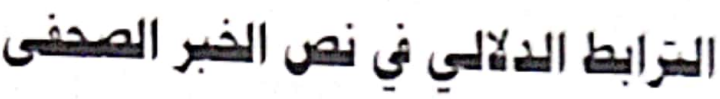

يتنى اللتر أبط الالالمي في النص وجوح تز ابط مفيومي بين مكونات الـنص من الجمل و العبار ات و التزر اكيب و الثقر ات ويحكم هذا التزر ابط مجموعة من العلقات

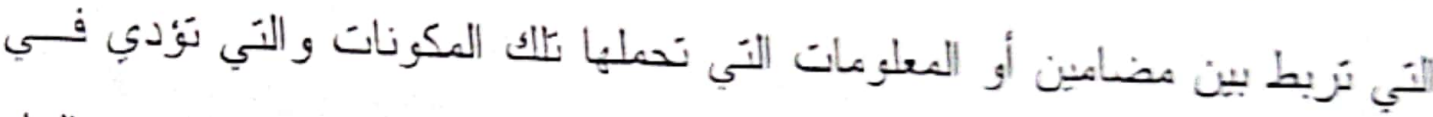

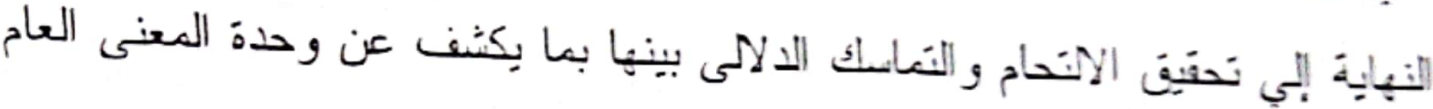

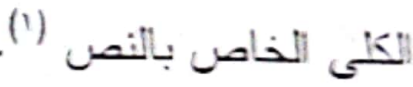

ويقصد بالعلاقات النتى تزبط بين المفاهيم أو المـضامين أنهـا " حلقـات

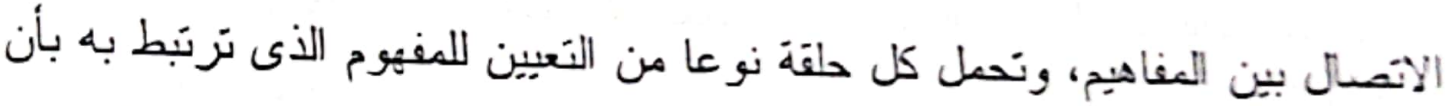

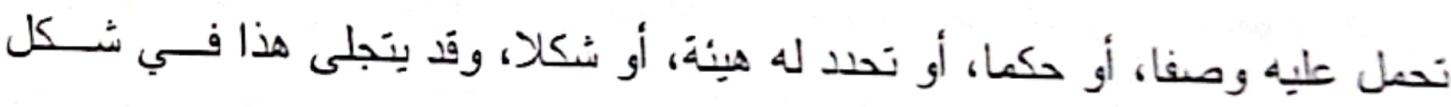
رو اببط لغوية و اضحة في ظاهر النص كما يكون أحيانا في شكل علقهـات ضــمنية

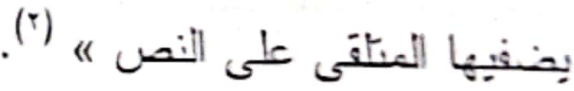

ومن العلاقات التَى تربط بين المفاهيخ: علاقةَ الإجمال و التفصيل والـسبب

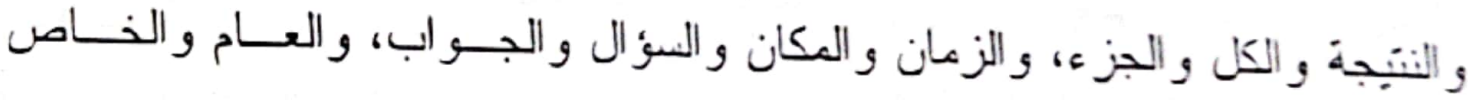

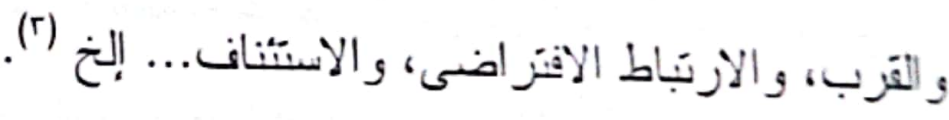

وبالنسبة للتزر ابط الالالى في نص الخبر الصحفي فإننا سنعرض للعلاقـات الدلاليــة النى تربط بين المفاهيم في هذا النص و التى تبذو كثيرة التذاول، ومن خلص رصدها

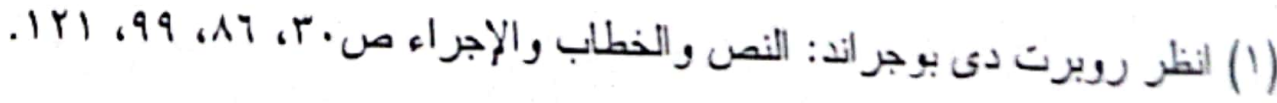

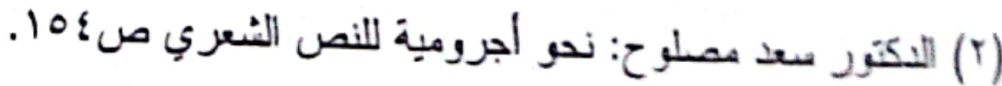

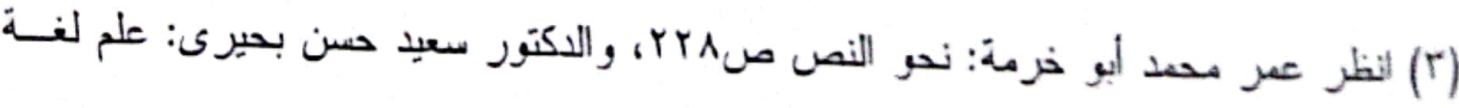




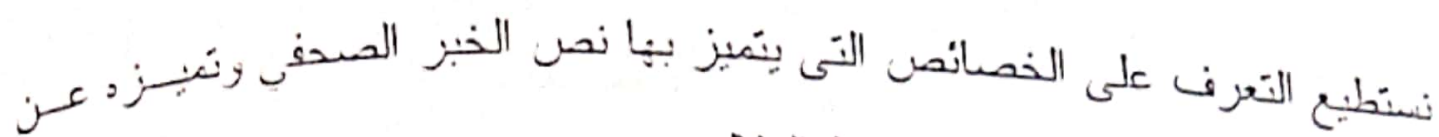
غيره من النصوص في مجال الربط الدلالى.

وسنركز في حديثا عن الربط الدالى في نص الخبــر الـصحفي بـصفة

عامة، وكذلك الربط بين مكوناته من الجمل و الفقرات ونشير إلى هذه الروابط فيسا.

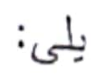

1- - علاقة الإجمال و التفصيل:

و هذه العلاقة من أوضح العلاقات التى يمكن ملاحظنها بنهولة في نسص

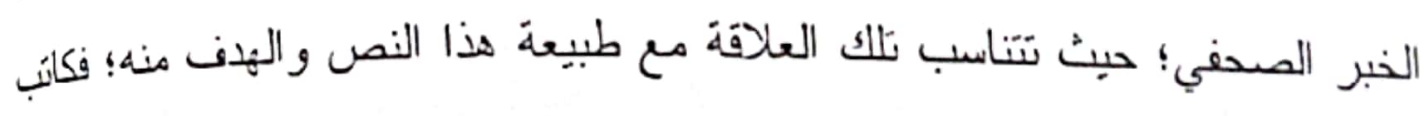
النص بهتم أولا وأخيرا بذكر الخبر أو المعلومة الأساسية التى تجذب انتباه القسارئ ويكون لها تأُّرِ في حياته من كافة النو احى، ويقوم بعرض الخبر أو المعلومة فسي مقدمة النص و هى غالبا ما ترد في موقع الجملة الأولى من هذا النص سواء أكسان

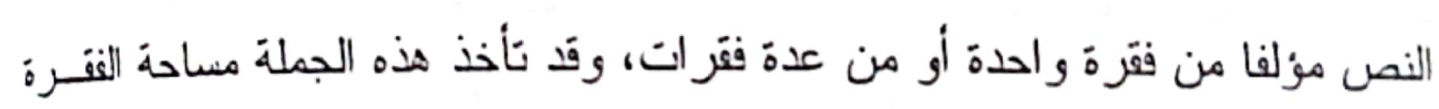
الأولى كلها، ثُ بقوم الكاتب بذكر التفاصيل المختلفة عن هذه المعلومة أو الخبر. فالتر ابط الدلالي في نص الخبر الصحفي إذن يقوم علــى إيـــراد الذبـر

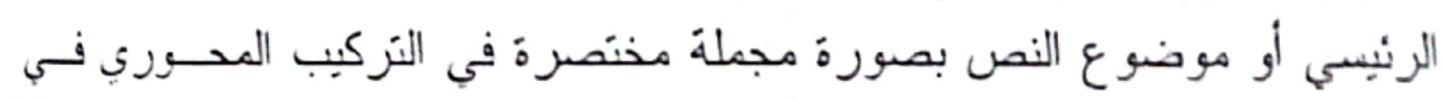
مقدمة النص نم بعرض تُصنبلة وتفسيره بعد ذلك على مدار النص كله.

وقد تكلم فان دايك عن وصف الأبنية العلبا للنــصوص أو البنبـة الكلبـة

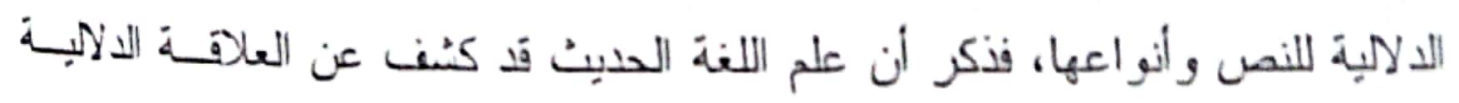
(المحور - التُسير) ببساطة على مسنّوى النص، وقال إن هذه العلاقة بنبغي النظــر

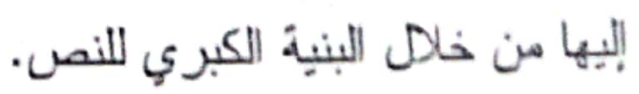




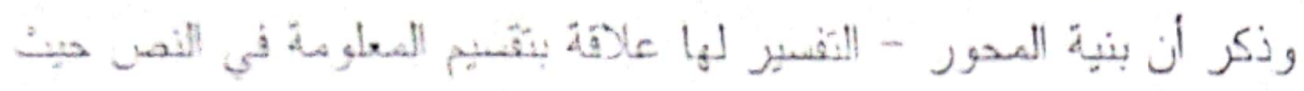

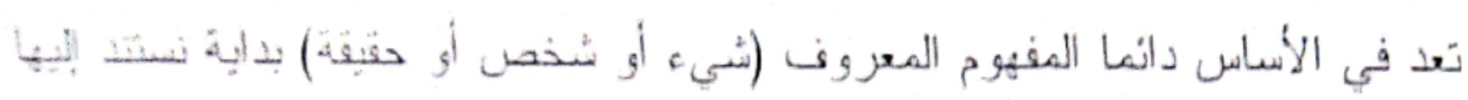

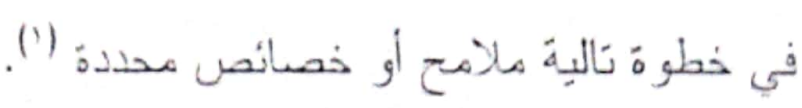

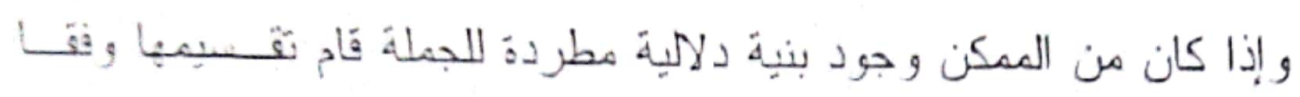

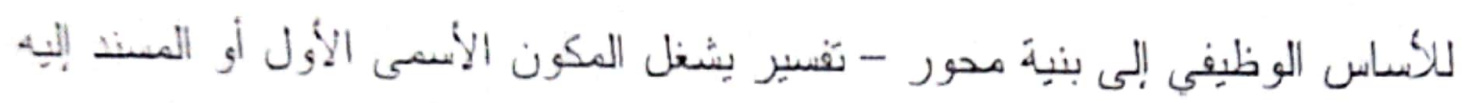

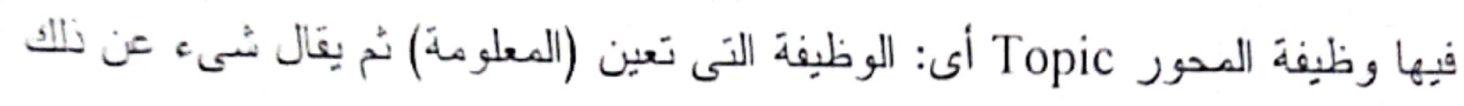

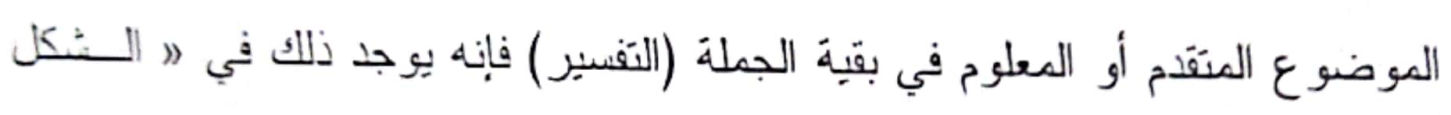

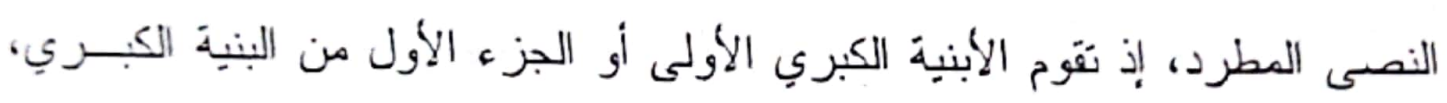

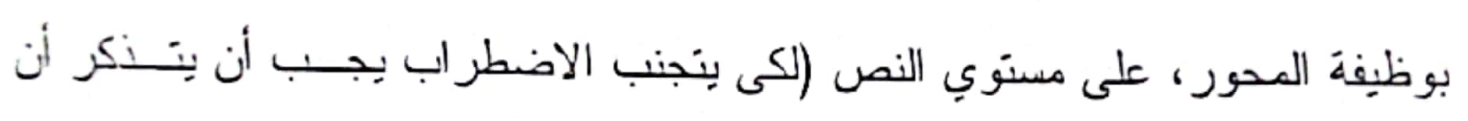

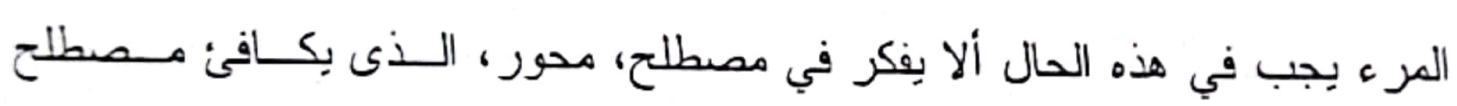

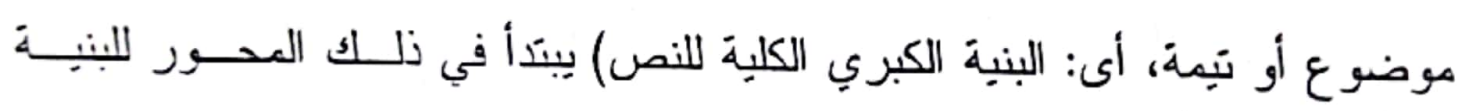

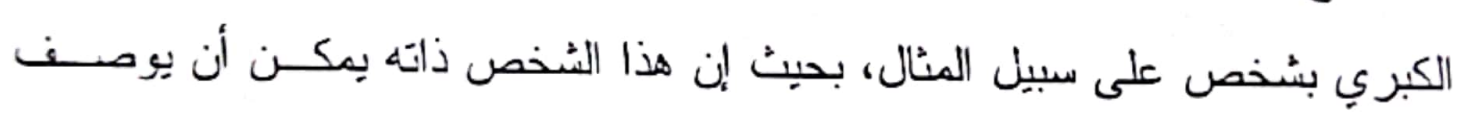

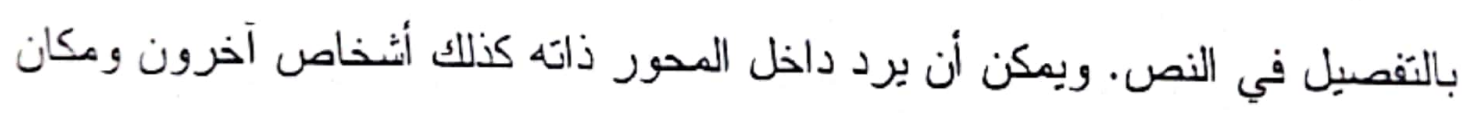

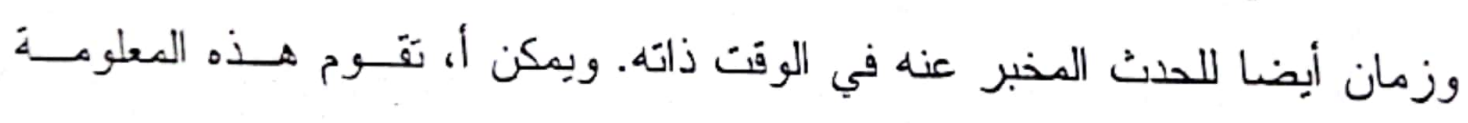

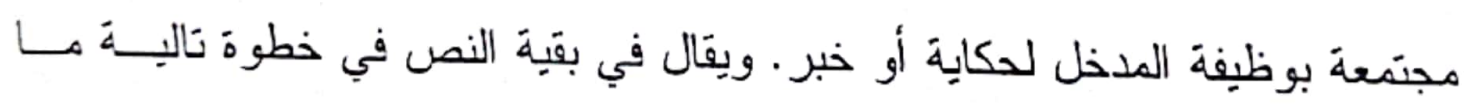
المهم بر اجماتيا لان بخبر عن الأشخاص المذكورين، بحيث يقوم هذا بوظيفة تُفسير

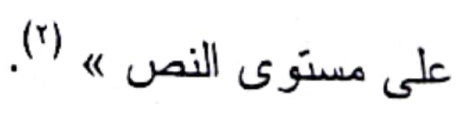

وبمكن أن نعرض لأمتلة هنا للعلاقة الدلالية (الإجمال و التفصيل) القائهـة

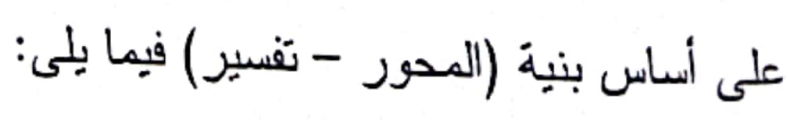

(1) علم النص صYrY. (r) السابق: صـr Tr. 
ير فلعة الكبش بالسبدة زينـبـب الهـبلال الأدمر

$$
\begin{aligned}
& \text { نص بعنوان: To مليون بندية لتطوير } \\
& \text { القاهزة وباربس بساهون ني في الششرو ع. } \\
& \text { اللصس هكون من فقزة واحدة هى: }
\end{aligned}
$$

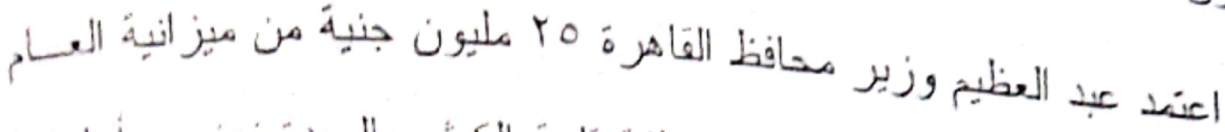

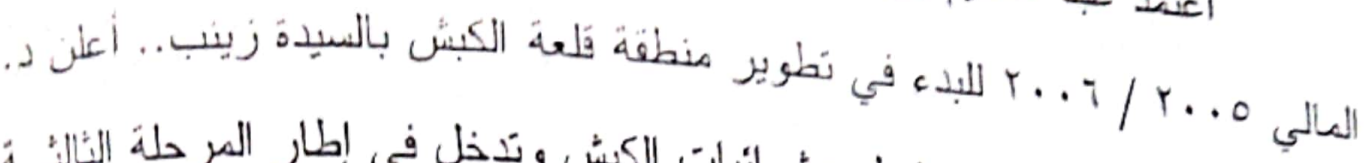

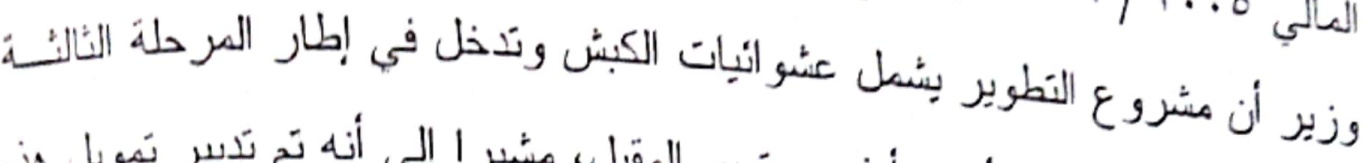

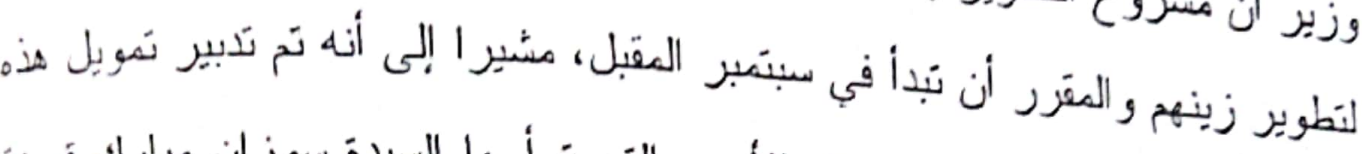
المرحلة بالتعاون مع جمعية الهال الأحمر التى تر أسها السيدة سوز وان مبارك قَربينة

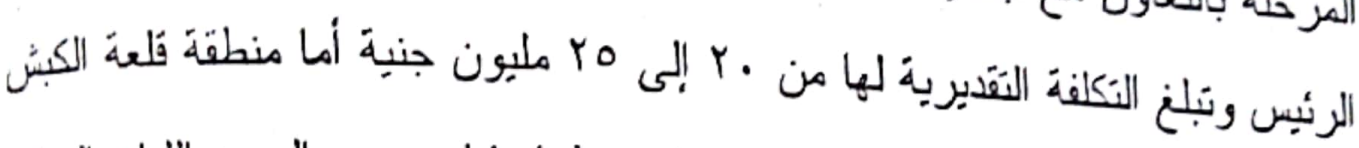

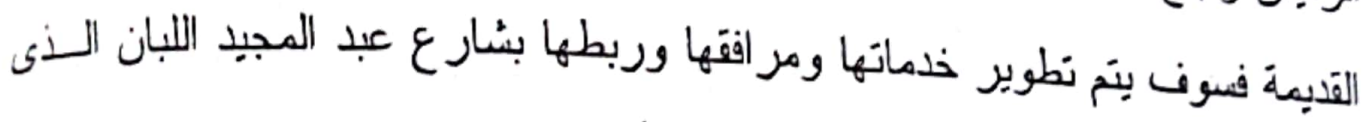

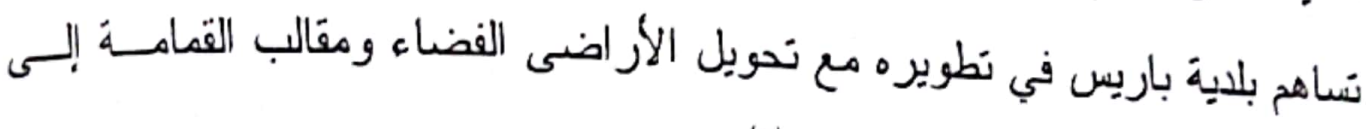
حدائق وتبلغ التكلفة ستة ملايين جنية|")

فقي النص السابق فكرة رئيسية تمثل موضو ع النص و هى: نطوير منطقة

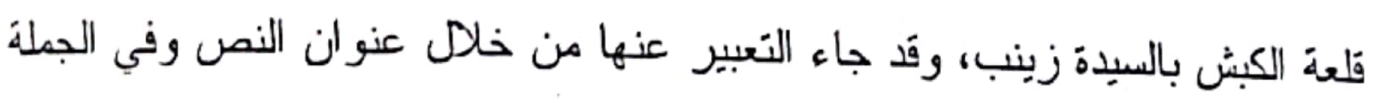

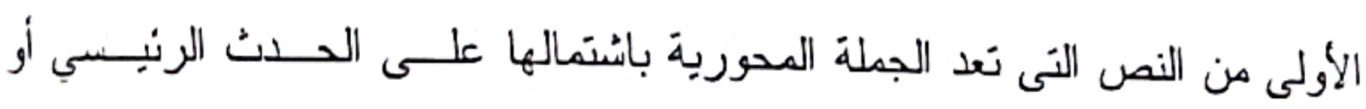

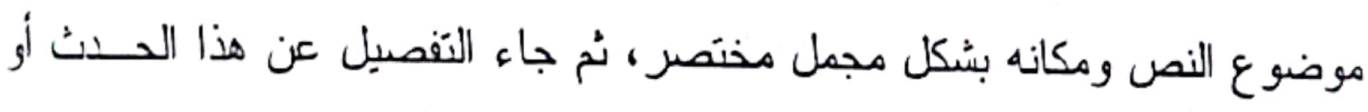

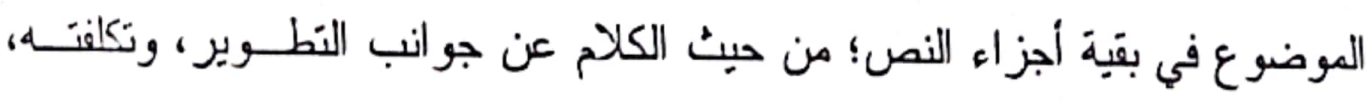

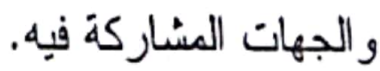

والجملة المحورية في النص السابق هى: 》 اعتمد د. عبد العظــيمِ وزيــر محافظ القاهرة Yo مليون جنية...للبدء في تطوير منطقة قلعة الكبش بالسيدة زينب).

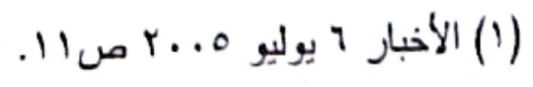




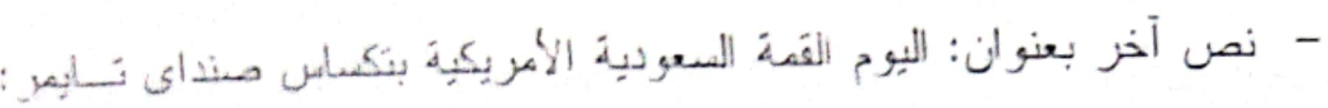

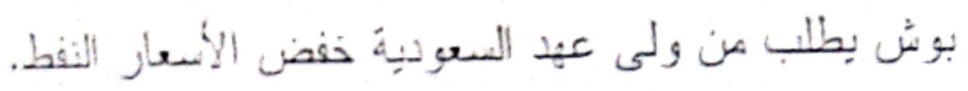

$$
\text { - - النص مكون من أربع فتر ات هي: - }
$$

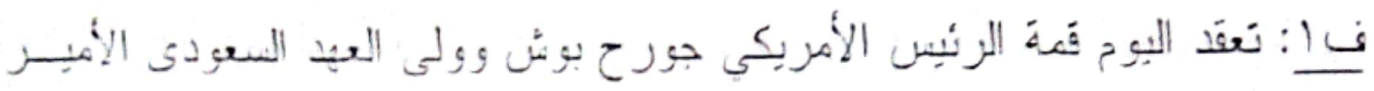
عبد الثهن بنب العزيز في مزرعة الرئيس الأمريكي في كراوفي رد بنكساس.

فـr: أكد مسئولون أمريكيون أن قضية السلام في الثنرق الأوسط وارتخاع أسعار النفط وما نسمبه و اثنطن بالحرب على الإزهاب سنكّن أبرز الموضو عات على جذول أعمال القَة.

نـr: كان سكوت ما كليلان الستحث باسم البيت الأبيض قد أثثار إلـى أن القــة ستتاول أيضا جهود الإدارة الأمريكية لافع الإصلاح الدبمقر اطي فـي الـشرق

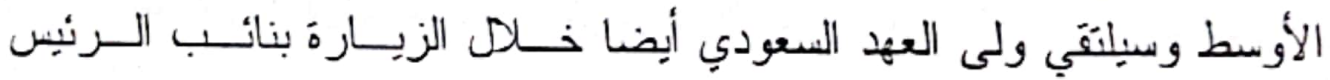
الأمريكى ديك تشنيى والرئيس الأسبق جورح بوش الأب. بضم الوفد السعودى الرسمى المر افق للأمير عبد اللهوزير الخارجية الأمبز سعود الفيصل ومـسـاعد رئيس المخابرات العامة الأمير فيصل عبــد الله آل سـعود وسـفير الـسعودية بو اشنطن بندر بن سلطان و.زير النفط السعودى على النعيمى.

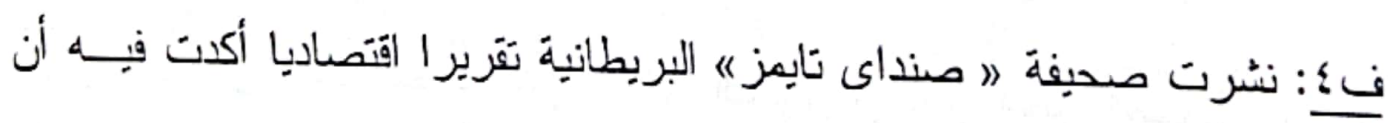
بوش سيطلب من الامير عبد الله الحد من ارتفــاع أنــعار البتــرول باعنبـار السعودية أكبر منتج للنفط نسبت الــصديفة إلـى الجمهـوري فرانــك لــوتنز المتخصص في اسنطلاعات الرأى قولــه إن العلاقة طردية بين ارتفاع أسـعار النفط وتصاعد كر اهية الأمريكيين اللسعودية. من جهة أخـرى دعــت منظمــة 


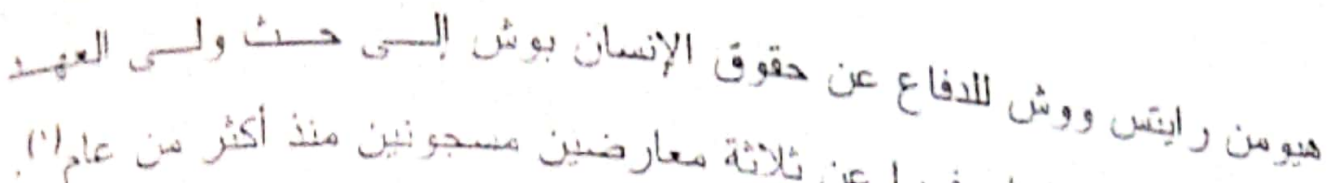

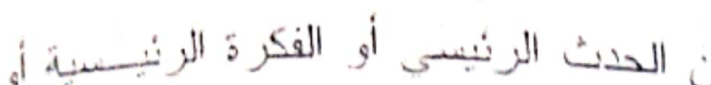

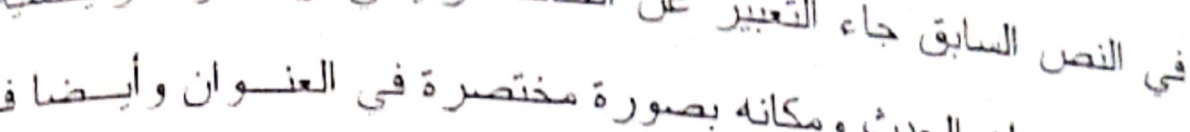

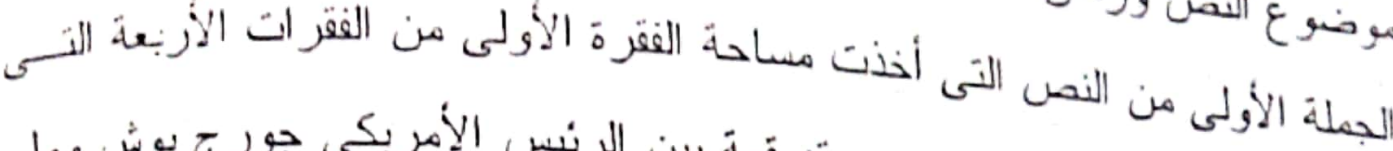

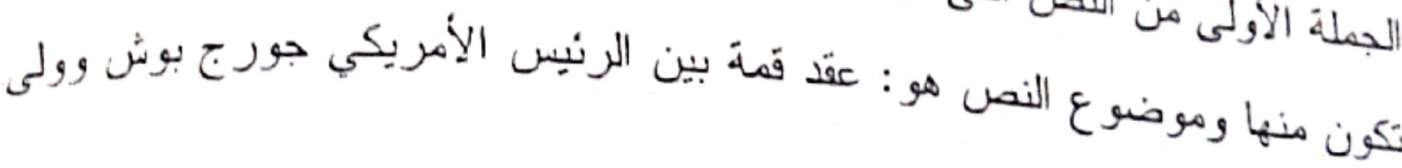
عهز السعودية الأمير عبد اله.

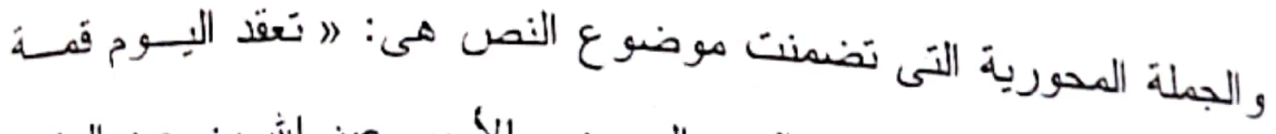

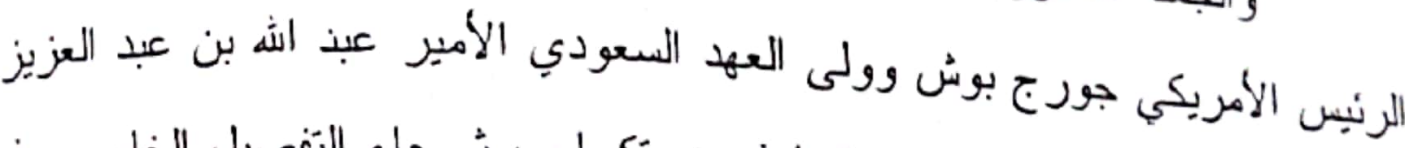

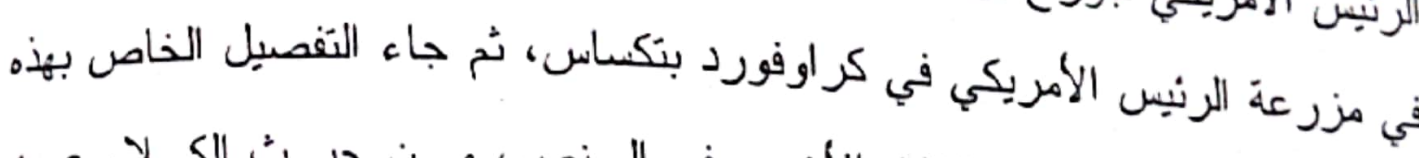

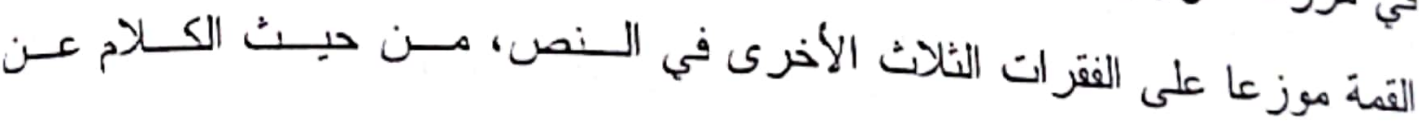
الموضو عات التي ستبحنها القمة.

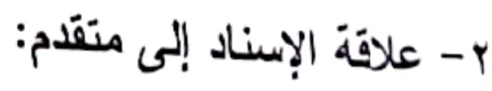

و هذه العلاقة كذلك من العلاقات الواضدة الكثيرة الاسنعمال التى ينمبز بها نص الخبر الصحفي وتعمل على نحقيق التماسك و الآتحام الدلالى بين أجزائه. وقد ذكرت عند الحديث عن التر ابط النحوى أن نص الخبر الصدفي يقّوم بنائه على وجود عنصر إئارى مركزى يعبر عنه في مقدمة النص وبالأحرى فـي

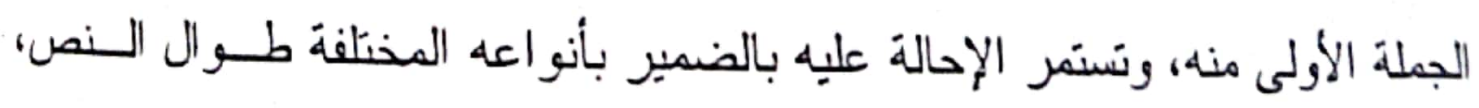

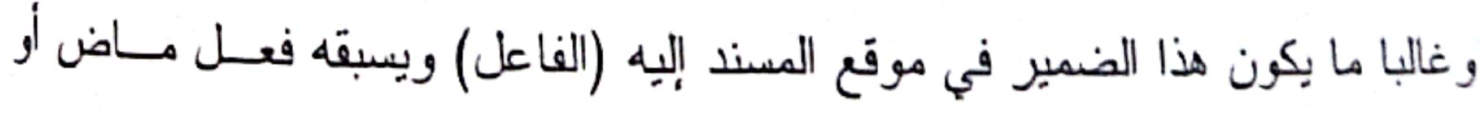

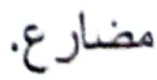

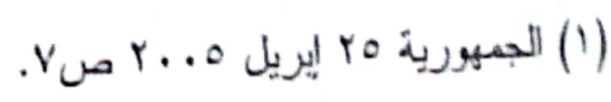




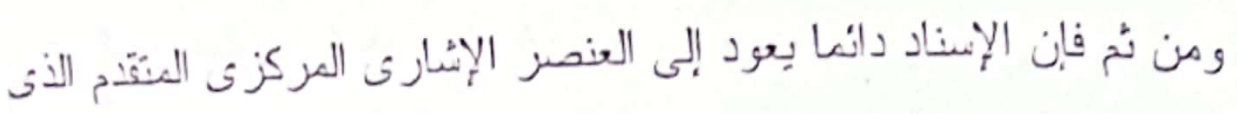

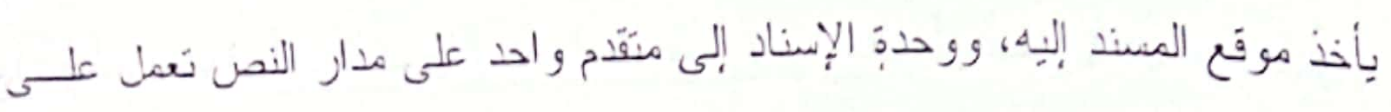

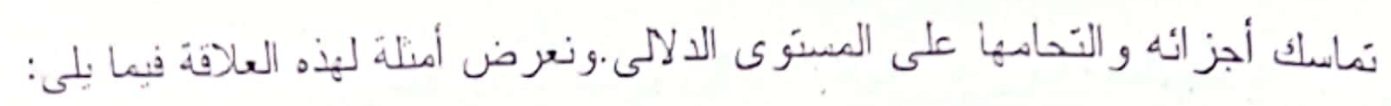

- نص بعنو ان أبر الغيط يتلقى اتصالات مكثفة من وزراء خارجية دول العالم:

- النص مكون من خمس فقرات.

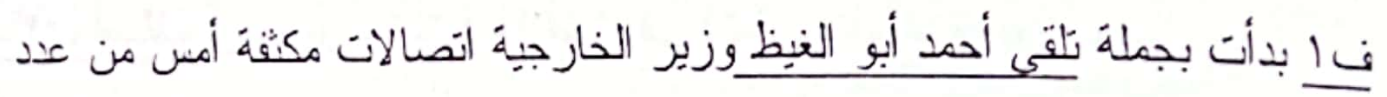

كبير من وزراء خارجية دول العالم....

ني بدأت هذه الفترة بجملة: وقال أبو الغيط إنه ستبدأ في بدابة الأسبوع القادم سلسلة

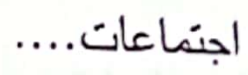

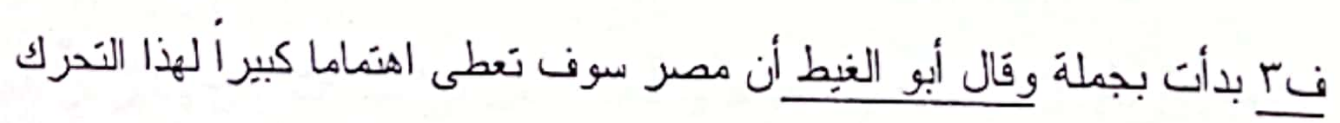
نيك بدأت بجملة و أشار وزير الخارجية إلى العليات الإرهابية فى بريطانيا وأسبانيا وتركيا وروسيا وغيرها

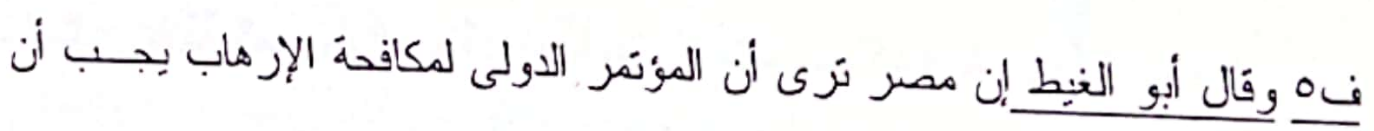

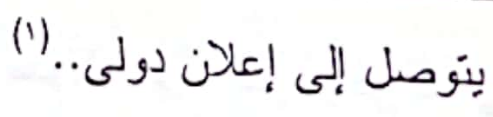

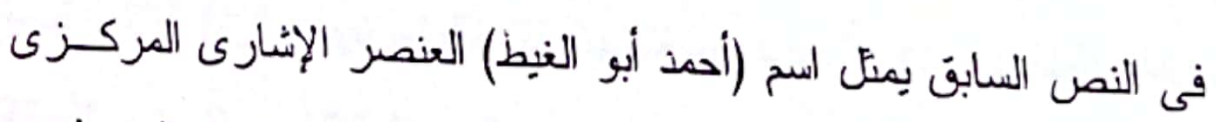

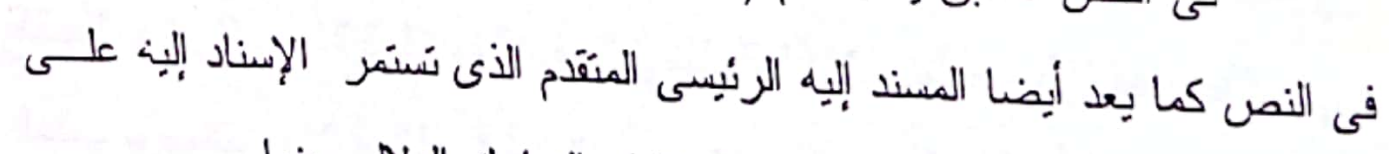
مدار فقرات النص مما أدى إلى الوحدة الدالية والتماسك الدالاي بينها.

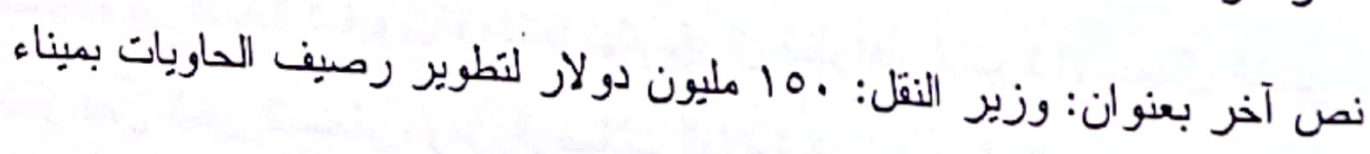
بورسعيد.

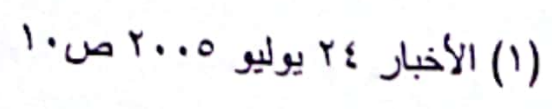




$$
\text { - النص مكون من خمس فقرات: }
$$

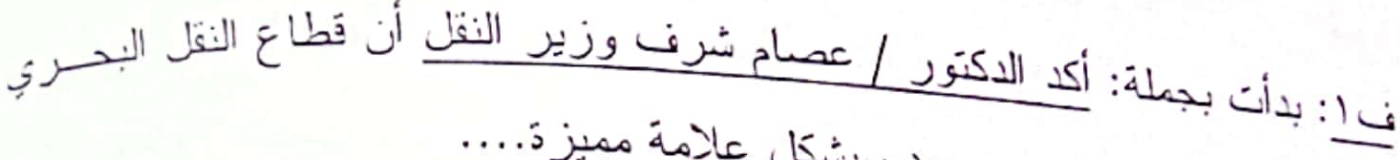

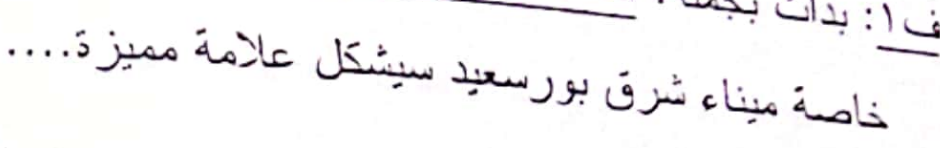

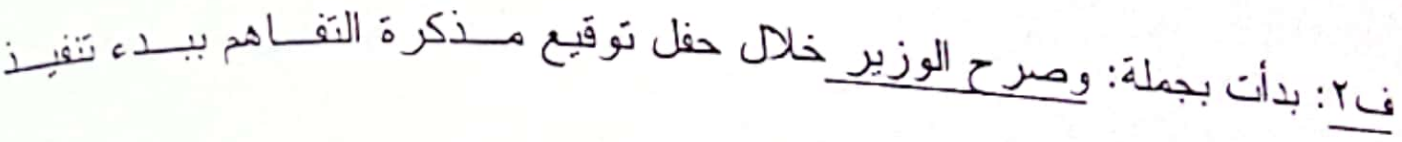

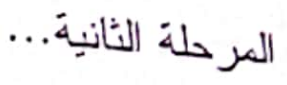

تبr: وأضفاف أن مصر ستسترد ما أنفقته في إنشاء ميناء شرق بورسعيد. نـ وقال الوزير إن ميناء شرق بورسعيد نجح في جذب العديد من سنن الخطـوط

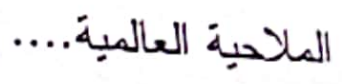

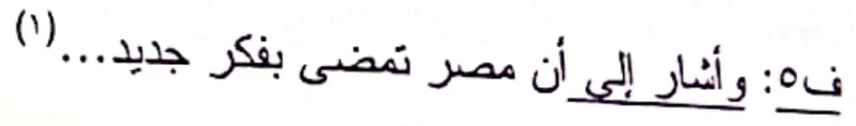
يمثل اسم وزير النقل العنصر الإشاري المركزي في النص، كما بمثل المسنــ

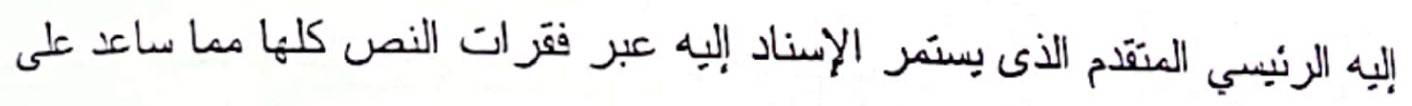
تماسكها وتر ابطها دلاليا. r- بلاقة السبب و النتيجة: تعنى هذه العلاقة أن شيئا ما يتوقف حدوثنة على حدوث شىء آخر ؛ وهى تسمى أيضا بعلاقة الترتب، وتربط العلاقة السابقةَ بين مكونات نــص الخبــر الــصدفي كالجمل و التر اكيب و الفقرات، وتؤدي إلى تماسكها دلاليا، ويعبر عن هذا العلاقة في الغالب بوصلات دلالبة ظاهرة في النص، ولا بعنى هذا أنها أى العلاقــة ليـست

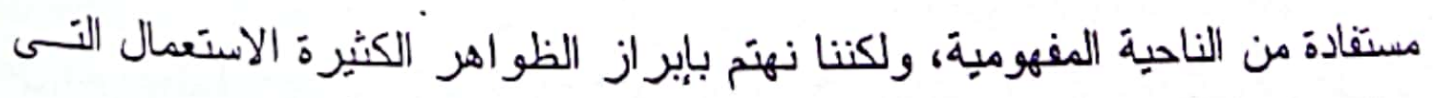
تميز نص الخبر الصحفي، ومن الوصلات الدلالية التى تستعمل للربط بين مكونات

(1) الأهرام r اغسطس ... r ص 10. 


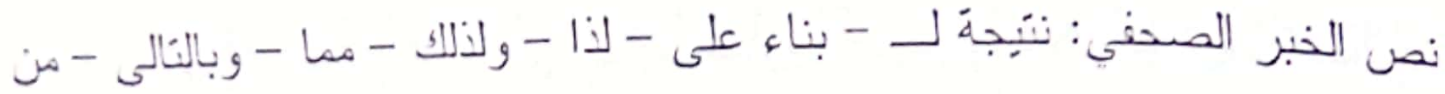

$$
\begin{aligned}
& \text { أجل ذلك - لأن - لكى... - لكي } \\
& \text { ونقدم أمتلة لدور هذه الوصلات في الربط الدلالي كما بِلي: } \\
& \text { أ- فمن أمئلة استخدامها للربط بين الفقرات: } \\
& \text { - نص بعنو ان: مكسبات طعم ولون نباتيَهة... أحدث الأبحاث. } \\
& \text { - النص مكون من ثُلاث فتز ات: }
\end{aligned}
$$

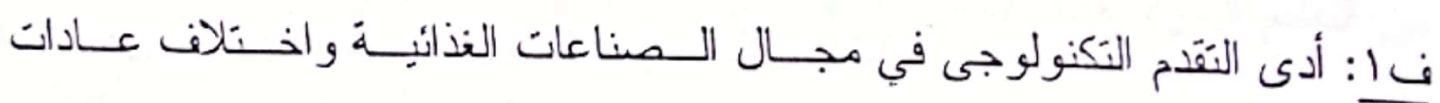

المستهلكين الغذائية إلى وجود كم هائل من المنتجات الغذائية تحنوى على نكهـات مختفة. وتسويق المنتج بعنمد على الاختلاف في النكهة........

نـr: ولكن المشكلة كما تقول د. هدى هانم فاضل في النكهات التى يعنبر تركيبهـا

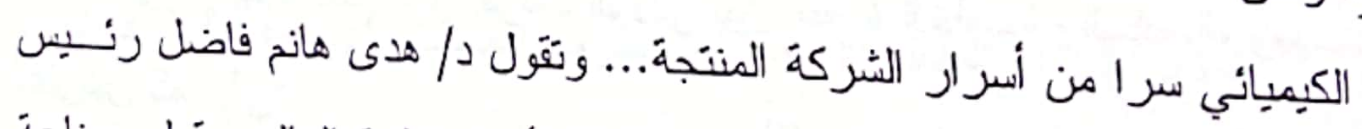

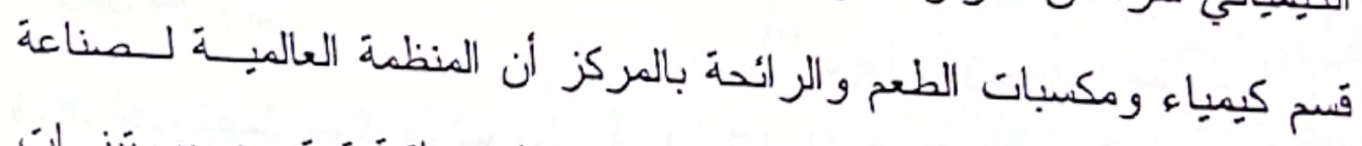

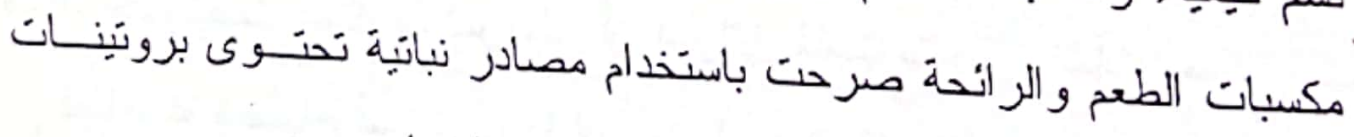
ومبتيدات و أحماض أمينية لتحضير العديد من هذه النكهات.

فـب: ونذا! فقد قامت د. هدى مع فريق بحثى بالقسم بتحضير بدائل لكل من الكاكساو

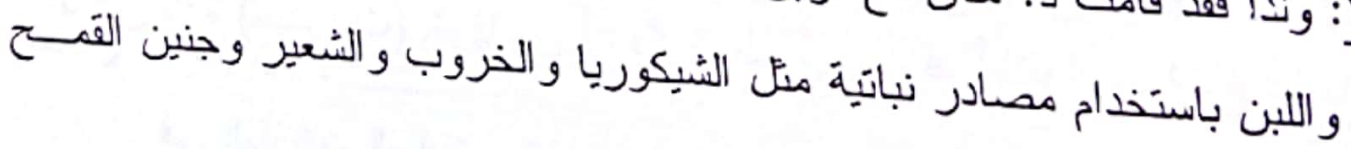

و وغير ها....

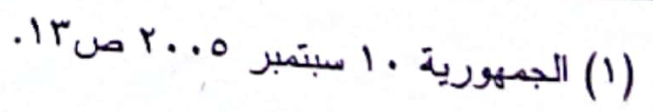




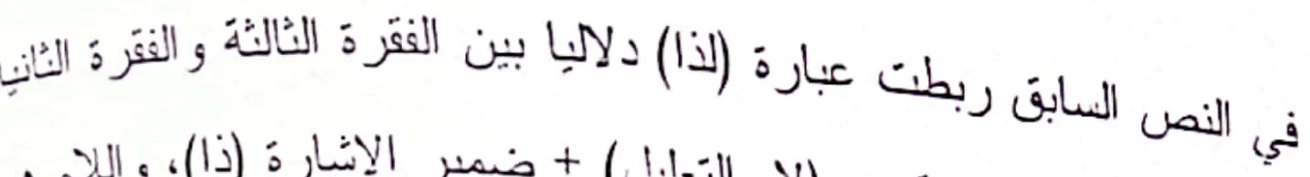

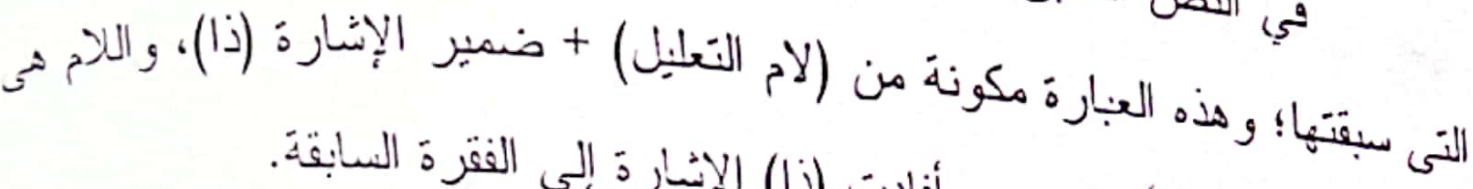
التى أفادت التعليل أو السبب، و أفادت (ذا) الإنشارة إلى الفقزة السابقة.

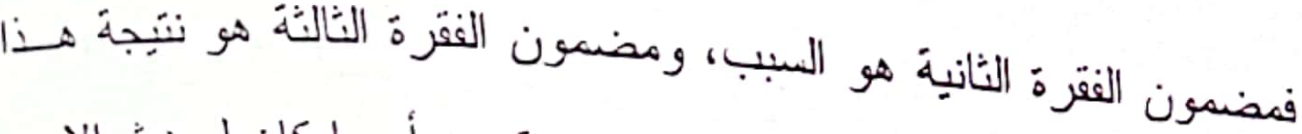

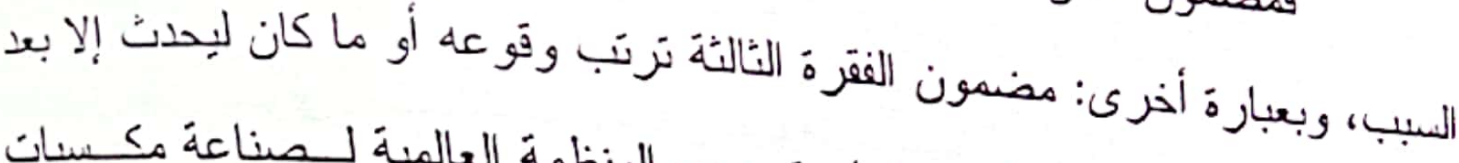

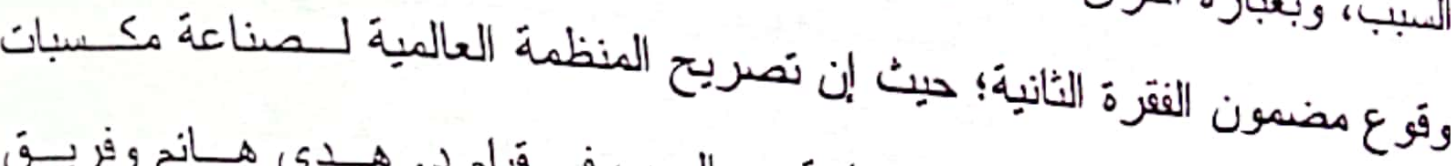

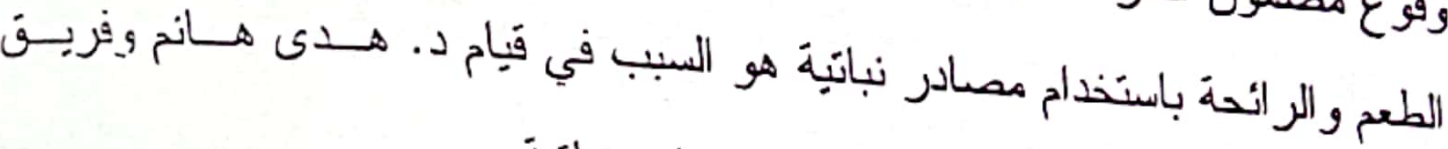
البحث من القَس بتحضير بدائل باستخدام مصادر نباتيَة. - نص آخر بعنوان إبر ائيل تحدد غدا المو عد الذهائي للانسحاب من غزة. - - النص مؤلف من تسع فقرات:

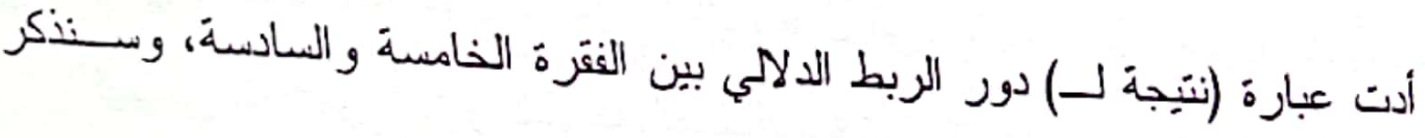
الفقرتين كما يلي:

فه: أكد متحدث عسكرى إسر ائيلى أن إبر ائيل قامت بتفجير منشآت عسكرية شمال

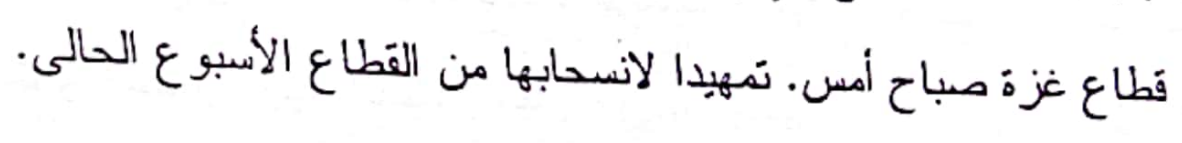
نَا: ونتيجة لذلك سمع دوى انفجارات شديدة في المنطقة وهو ما أثار الذعر بـين

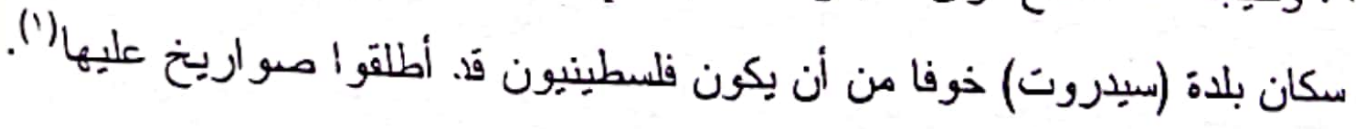

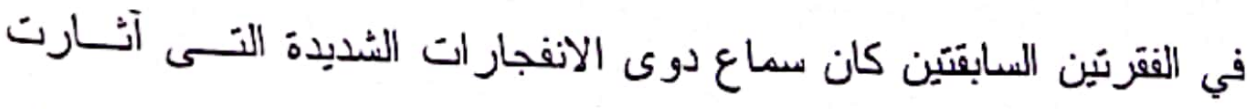
الذعر لدى سكان بلدة سبدروت، وهو مضمون الفقرة السادسة كان نتيجة سبيها قيام

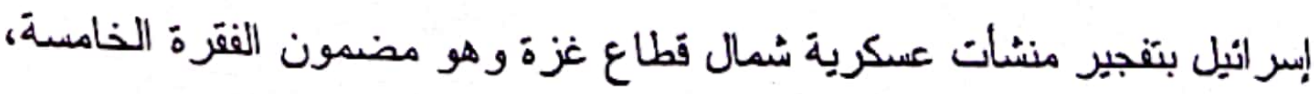

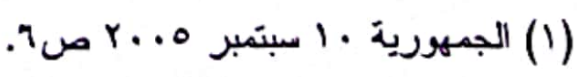




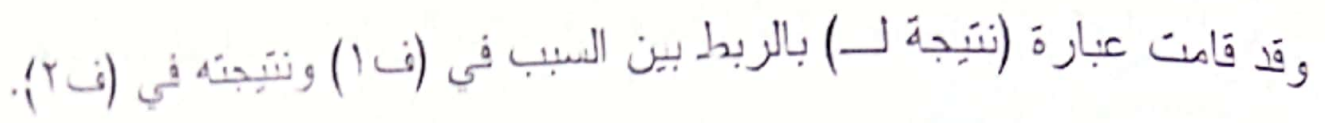

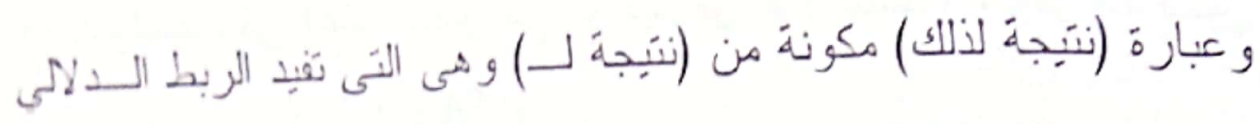 السابق، وضمبر الإنشارة (ذلك) الذى بشُبر إلى الفقرة الذامندة.

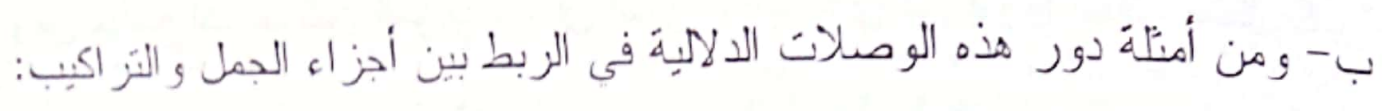 - و أشار إلى أنه سيتم و لأول مرة استخدام أحدث التكنولوجيا فـي إذخـال بيانـات}

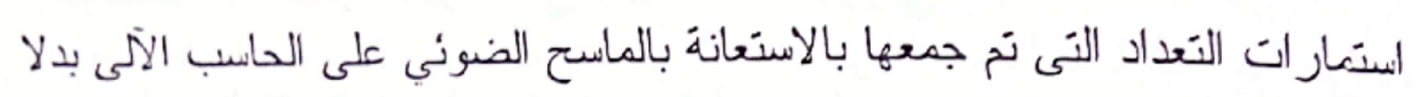
من النظام اليدوى مما بِضمن دقَة وسر عة إصدار بيانات التعداد (").

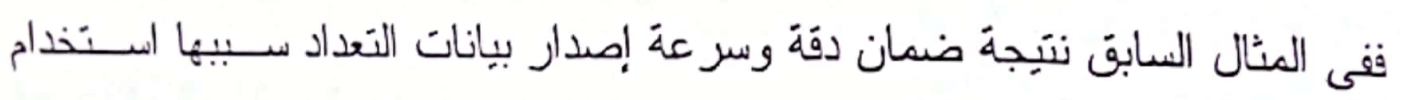

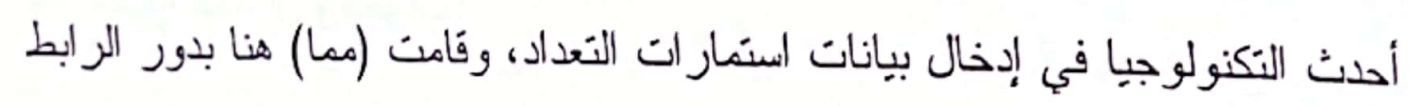
بين السبب ونتيجته. - وأشار الوزير إلى أن الطاقَة الاستيعابية للصرن الصحى بالإسماعلِية ارتغتتِ... وبالتالي ارتفع معدل تصريف الفرد (r).

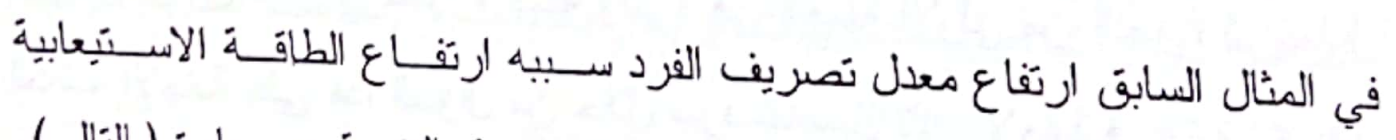
للصرف الصدى بالإسماعيلِية، والر ابط ببن السبب و هذه النتِّة هو عبارة (بالتالي).

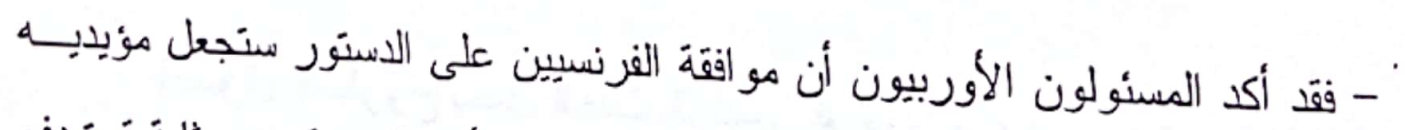

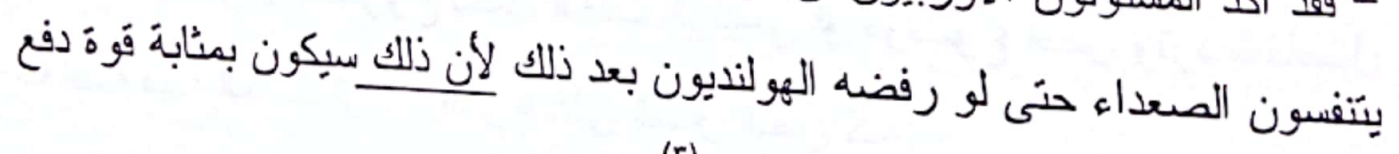

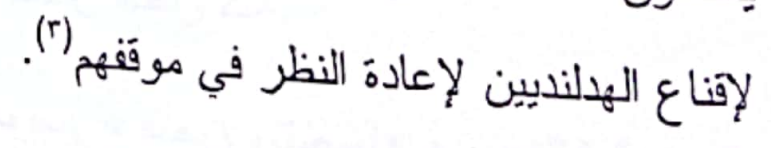

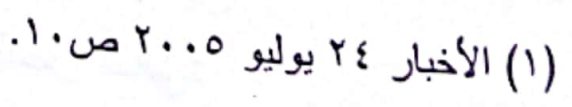

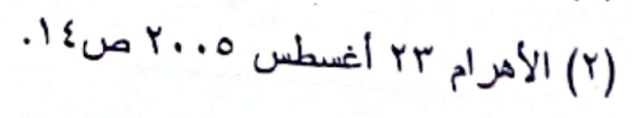

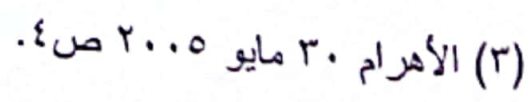




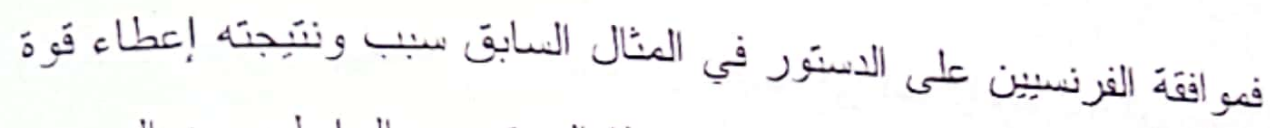

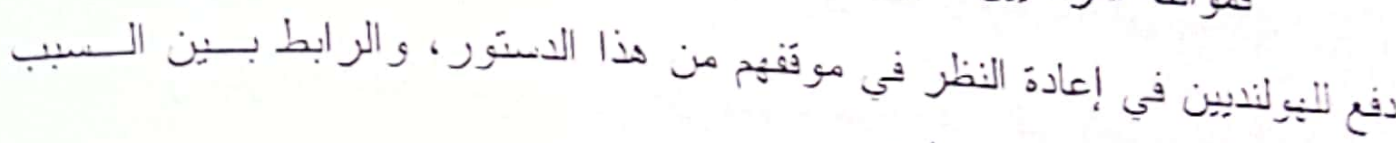

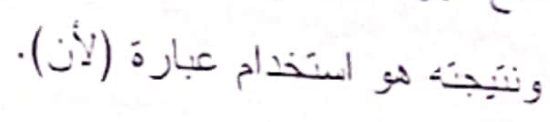

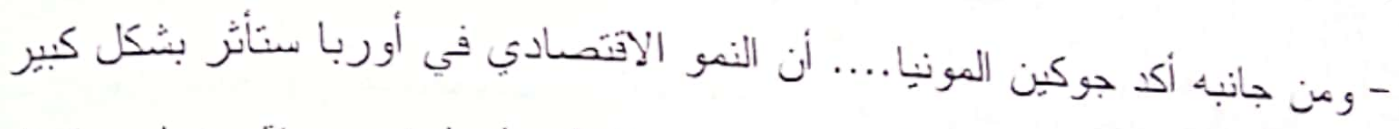

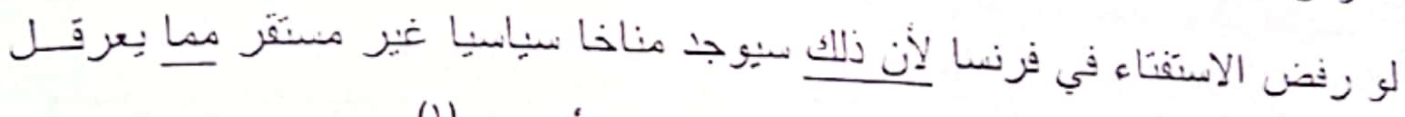

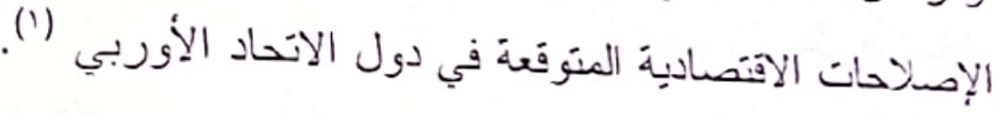
في العثال السابق أدت العبار ات (لأن) و (مما) دور الر ابط الـــلالي بـينين النبب ونتيجنَه في الجمل و التزر اكيبِ الو ارده فيه.

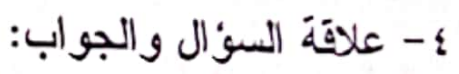

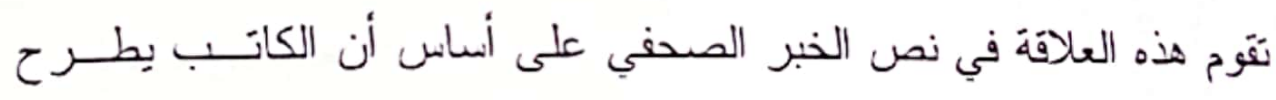

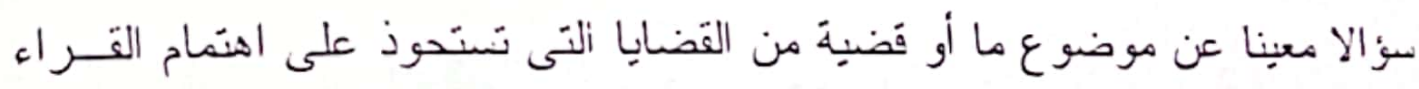

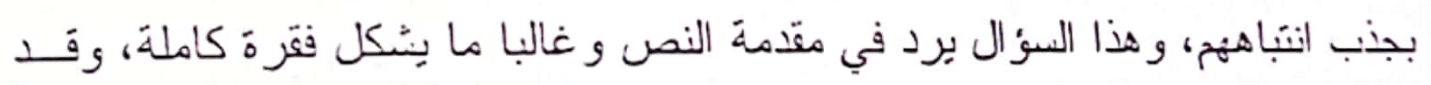

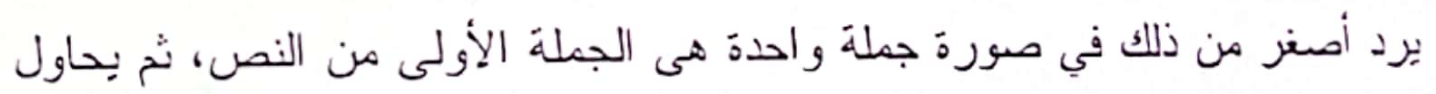

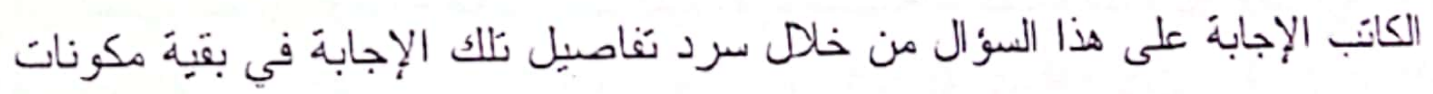

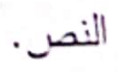

فالسؤ الل المطروح بحمل الحدث الرئيسي أو موضوع النص وترد التناصنِل الخاصة بهذا الددث أو الموضوع على المدار النص كله.

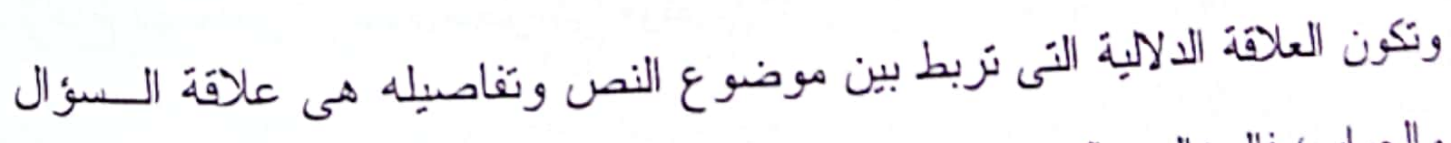

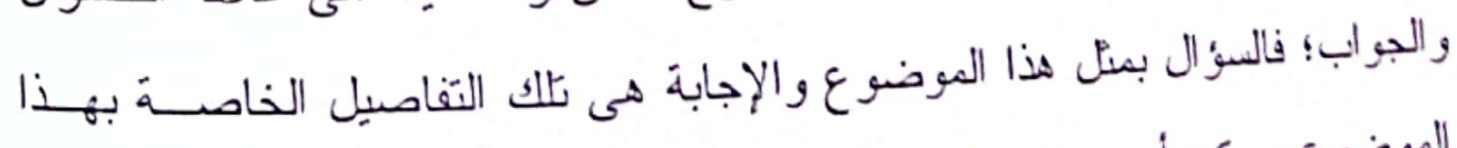

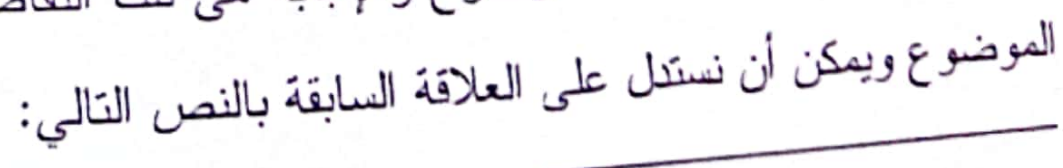

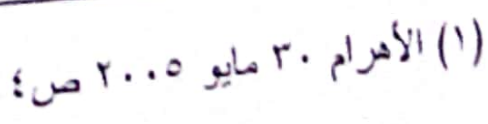




$$
\text { عنو ان النص معظم النساء قَبيدات... في عبن المز أة }
$$

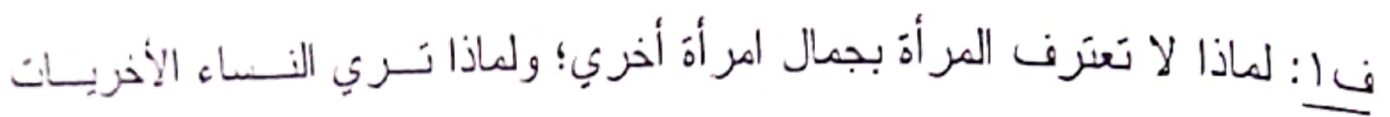

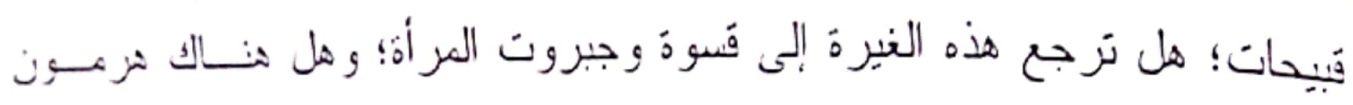

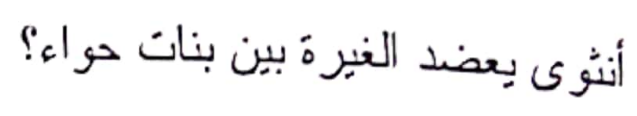

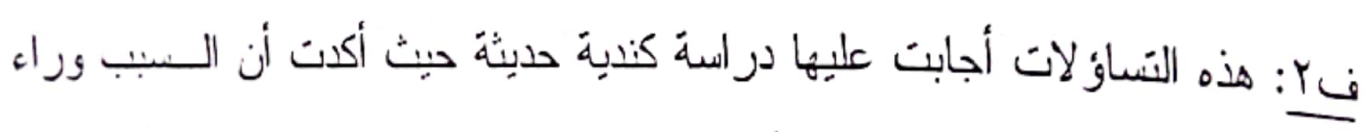
نظرة المر أة إلى الأخربات على أنهن قَبيحات برجع إلى روح المنافسة الموجـودة

$$
\text { في قلب حواء للحصول على زوج مناسب.... }
$$

نيسّ: وأرجعت هذه الدراسة نظرة المر أة للجميلات إلى أسباب هرمونية حيث تتعاظم

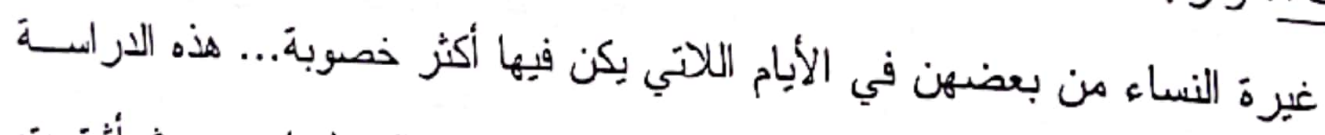

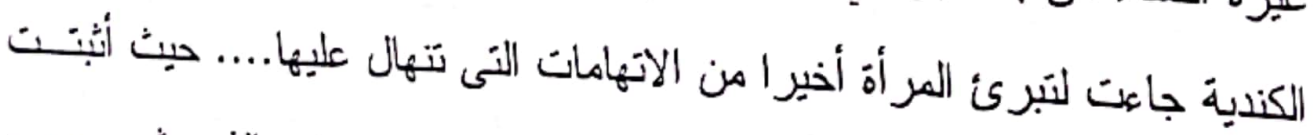

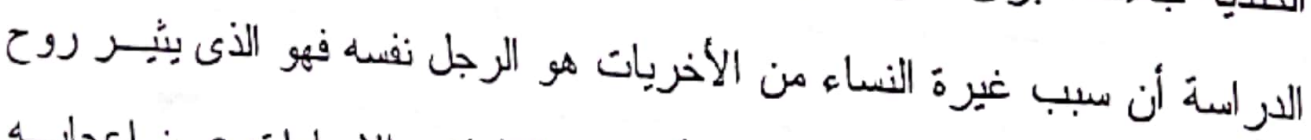

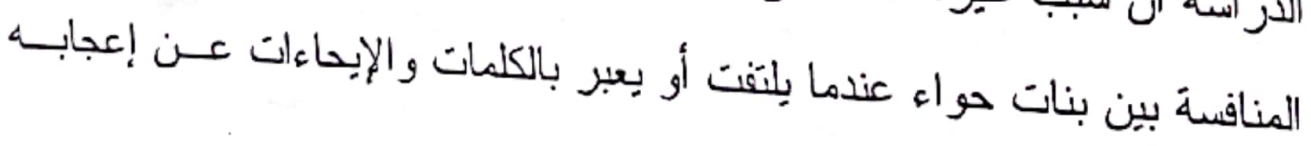

$$
\text { بسيده جميلة مرت بجو اره (1). }
$$

(1) الاهرام ع سبتببر r... مur. 


\section{الخاتَّة}

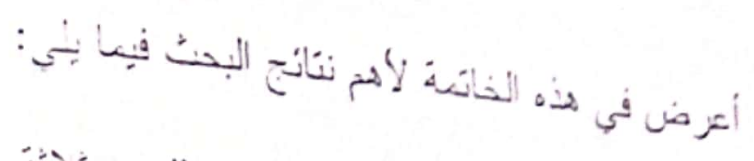

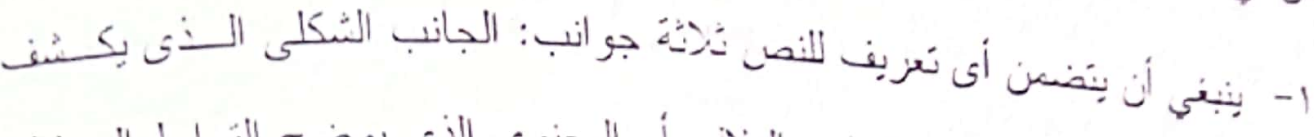

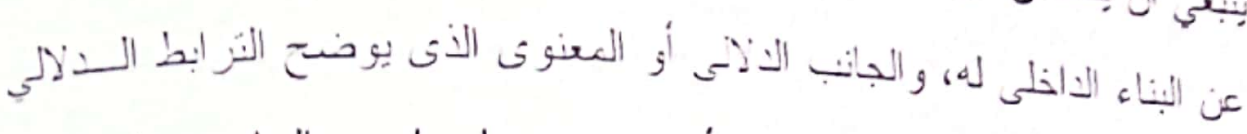

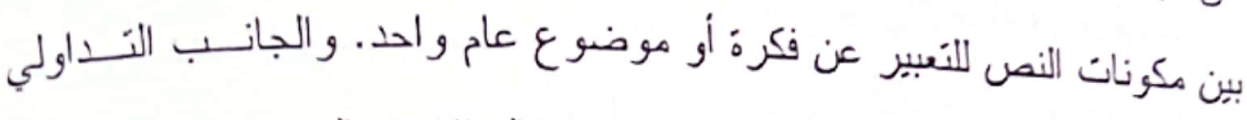
الذى بكثن عن الوظنية الاتصالية للنص من خلال الاسنَمال.

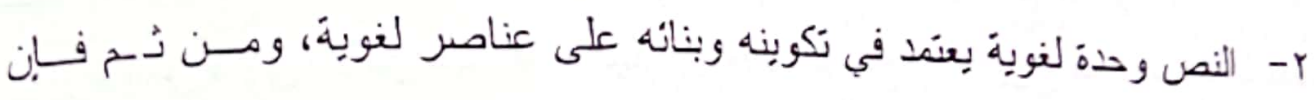

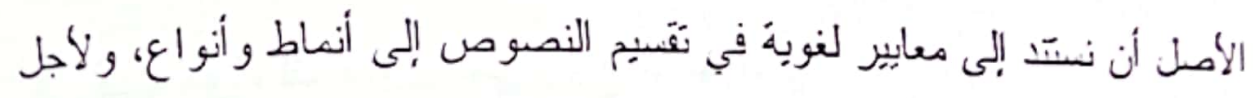

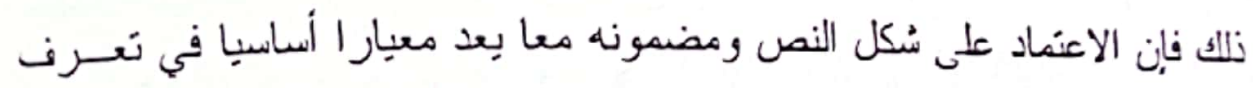

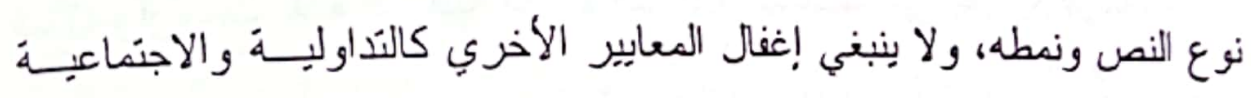
و الوظينية، ولكن بوصغها عو امل مناعذة.

r- نكُن خصائص البناء الداخلى لنص الخبر الصحفي من حيث الشكل عن تُفاوت

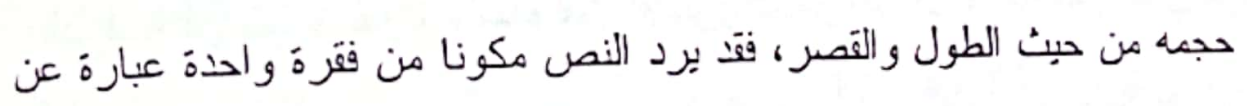

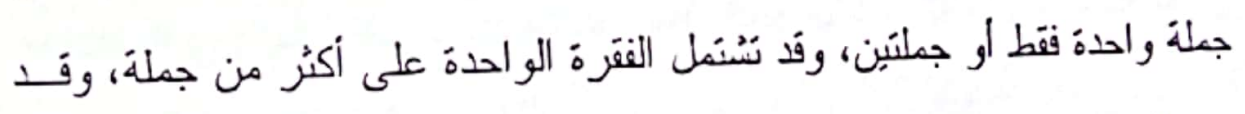

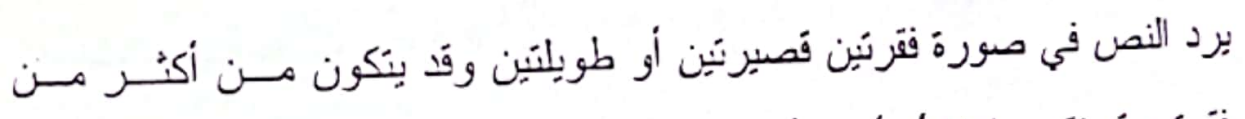

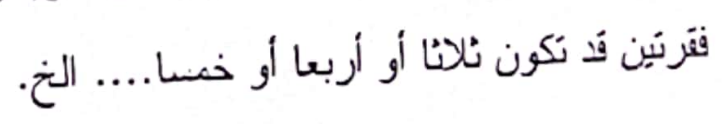

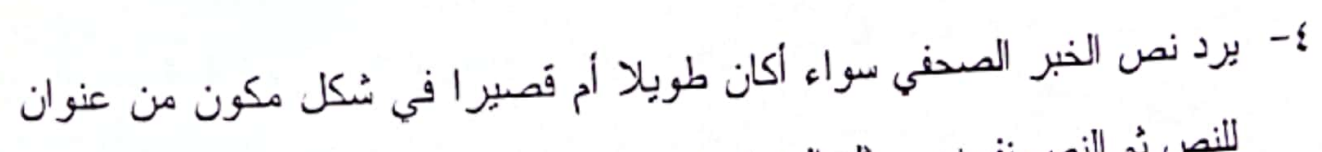

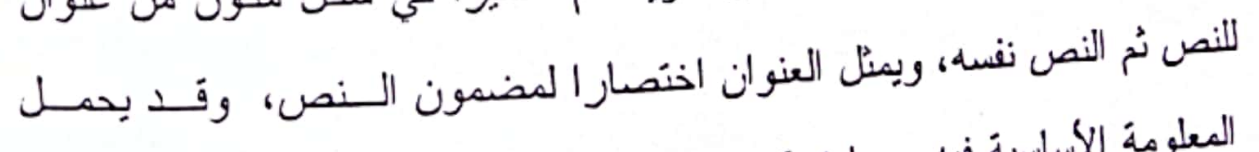

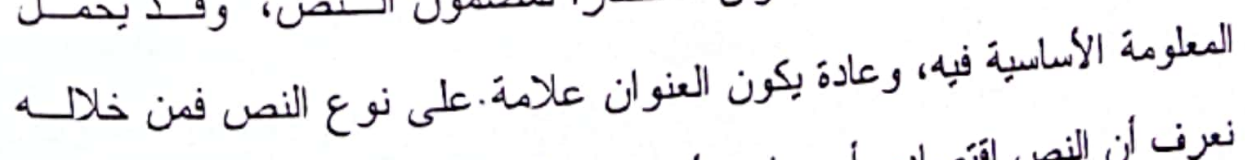

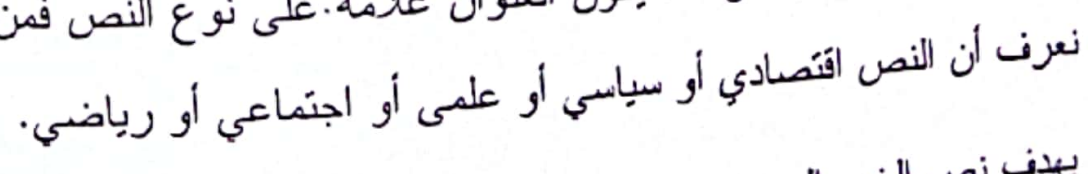

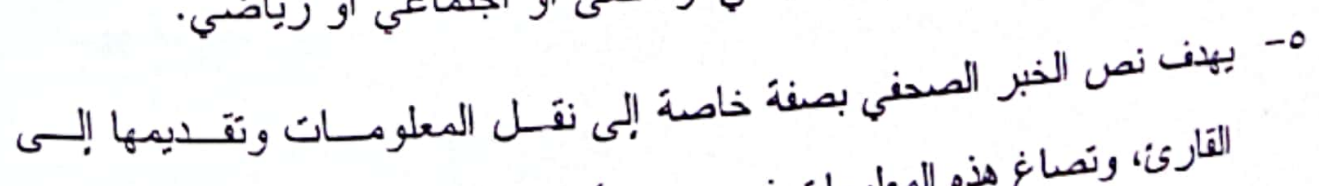

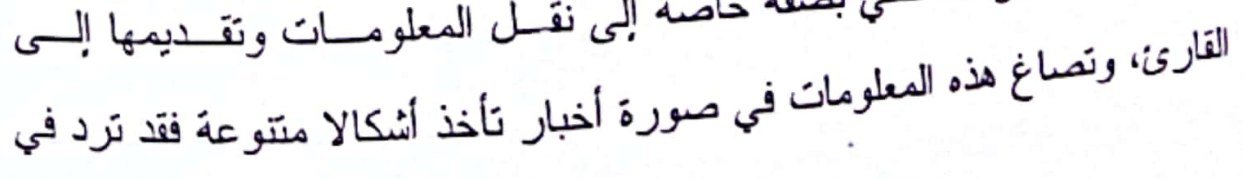




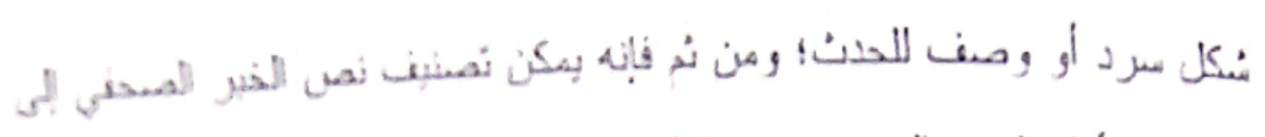

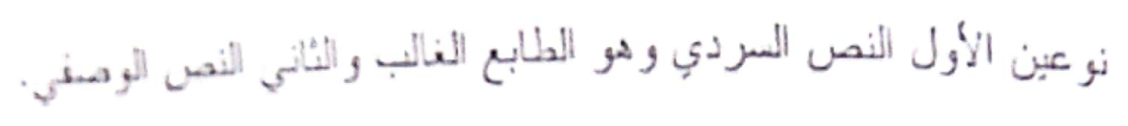

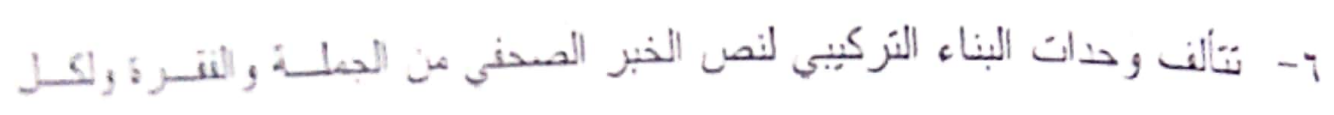
منهيا خصائص: - من

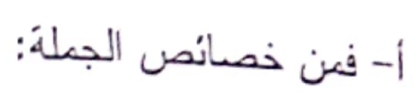

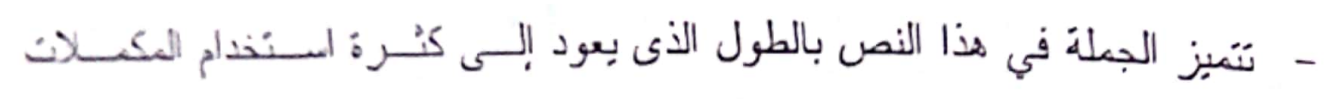

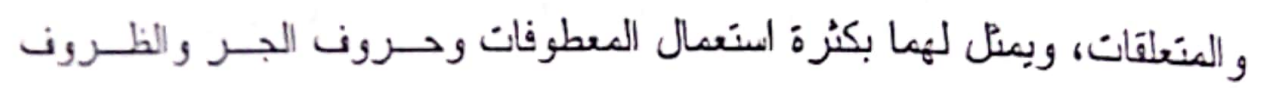

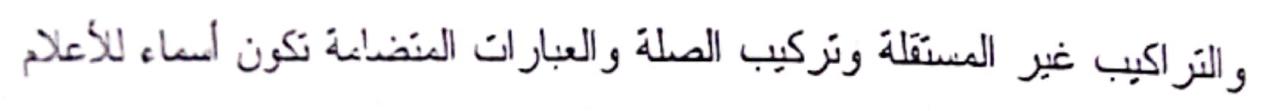

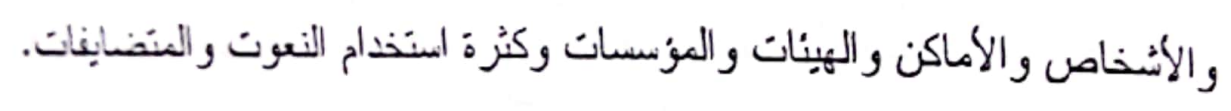
- مبرد عنوان النص غالبا في شكل جملة استبة، بينسا يرد النص نفسه غالبا مؤلنا عن

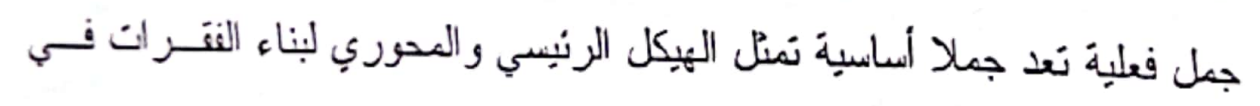
النص.

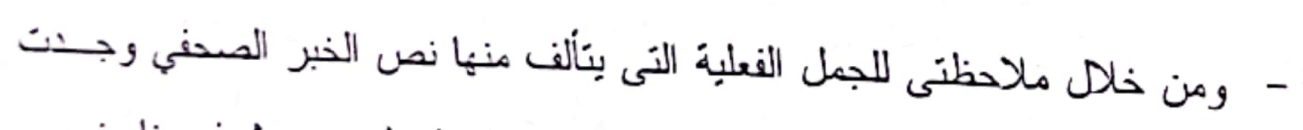

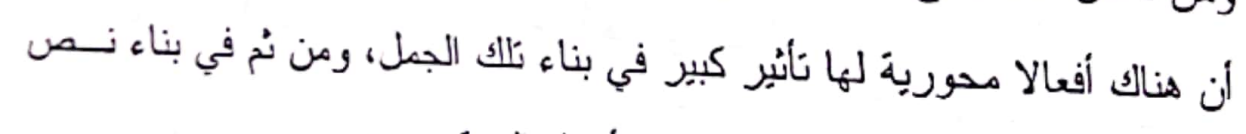
الخبر الصحفي عامة وبمكن تقسبه هذه الأفعال إلى قسمين:

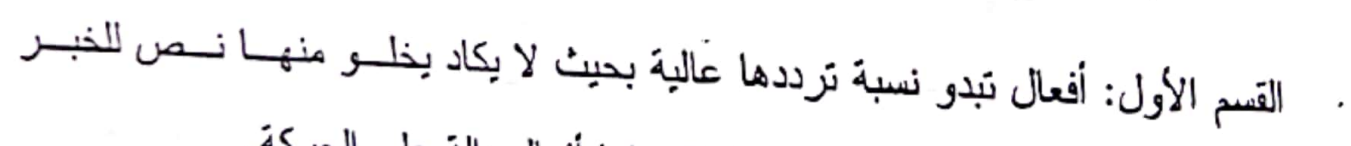
الصحفي؛ وهي إما أفعال دالة على الكلام وإبا أفعال دالة على الحركة.

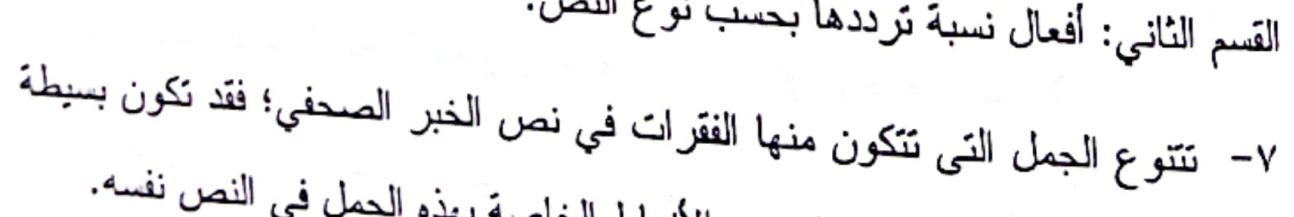

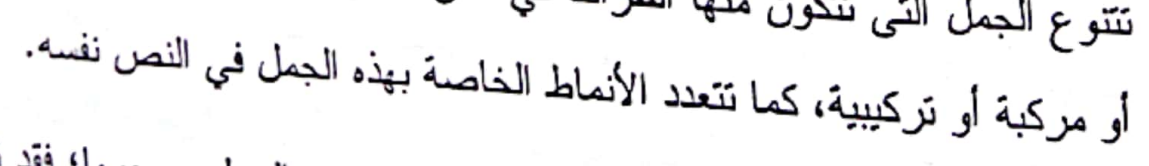
1- يتفاوت حجم الفقرة في نص الخبر الصحفي بحسب عدد الجل وحجمها؛ فقد ترد الفترة مكونة من جملة واحدة أو جملتين او أكثر من ذلك. 
9- بقوم بناء المضمون في نص الخبر الصـفي على عدد من العناصر التى نسنحكر

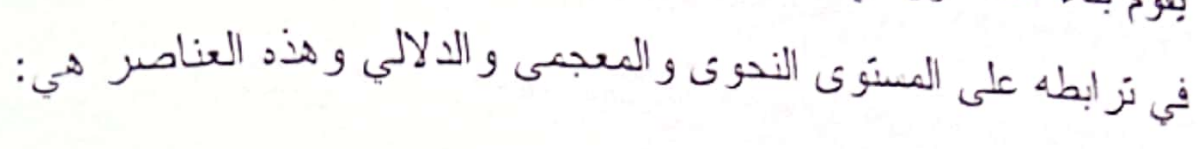

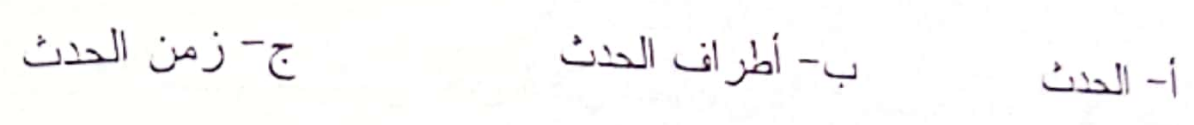

$$
\text { ج- مكان الحثن. }
$$

وبمنل الحدث دائما الفكرة الزئبسة أو المعلومة الأساسية أو موضوع النص الذى

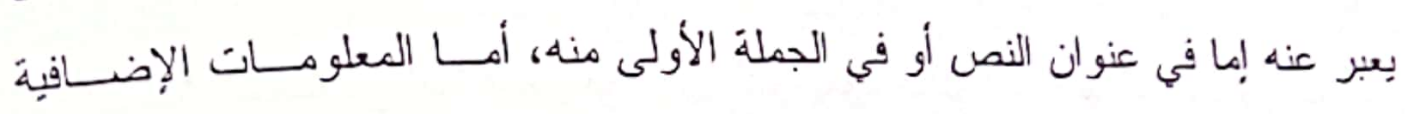

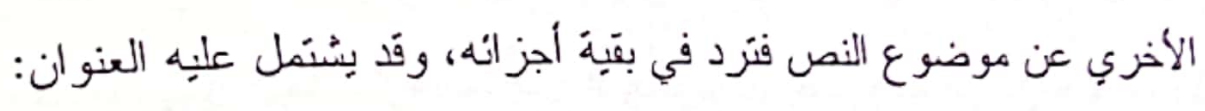

وغالبا ما نكون أطرات الحدث عبارة عن فاعل الحدث أو المشاركون في صنعه

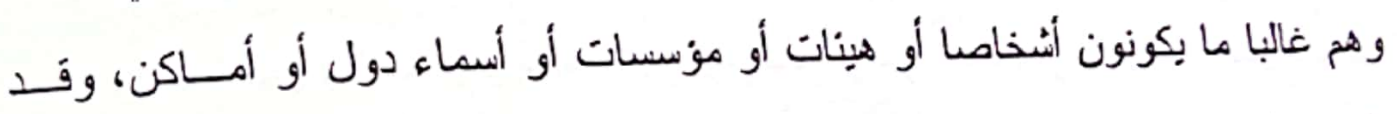

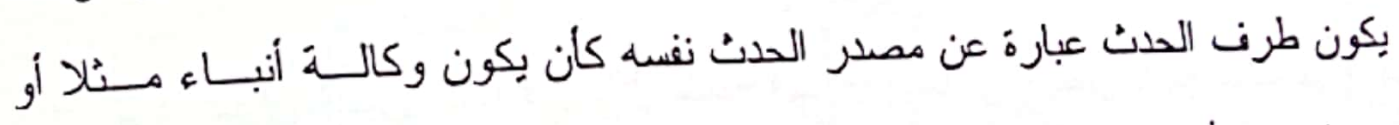

$$
\text { مصنر صحفي معين. }
$$

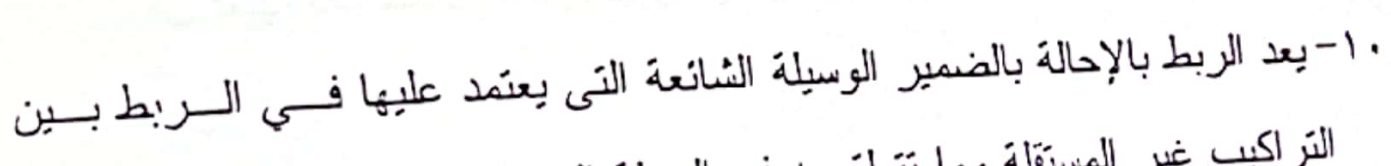

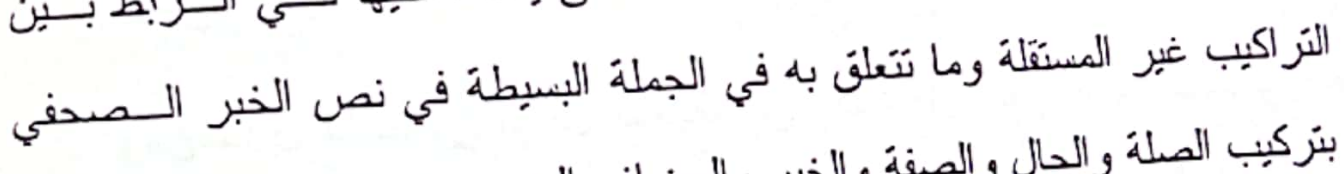

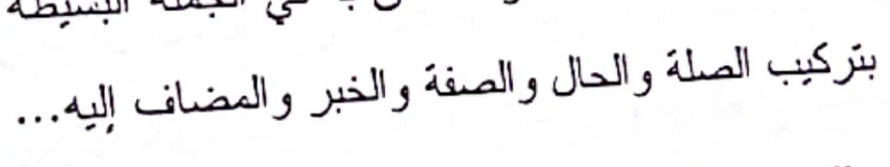

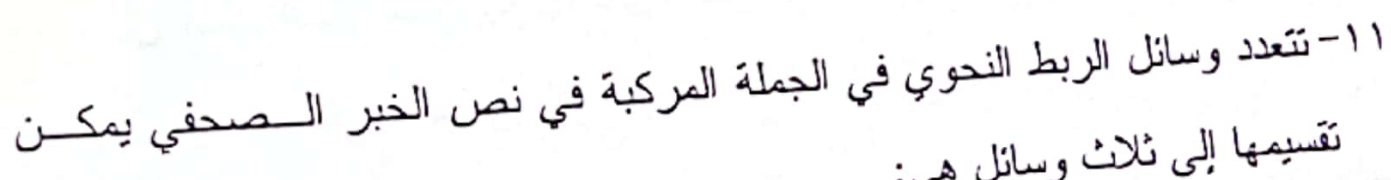

$$
\text { تقَسبِها إلى نُلات وسائل هى: }
$$

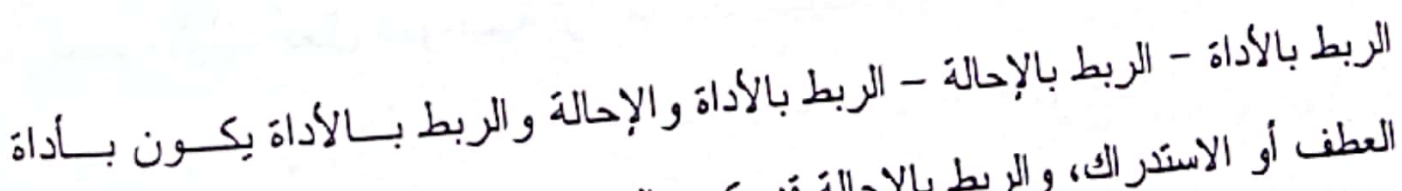

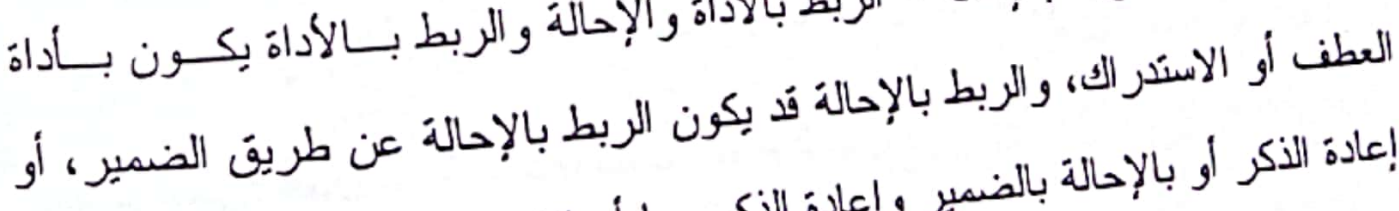
إعادة الذكر او بالإحالة بالضمبر وإعادة الذكر معا أو الإحالة بالاستبدال.

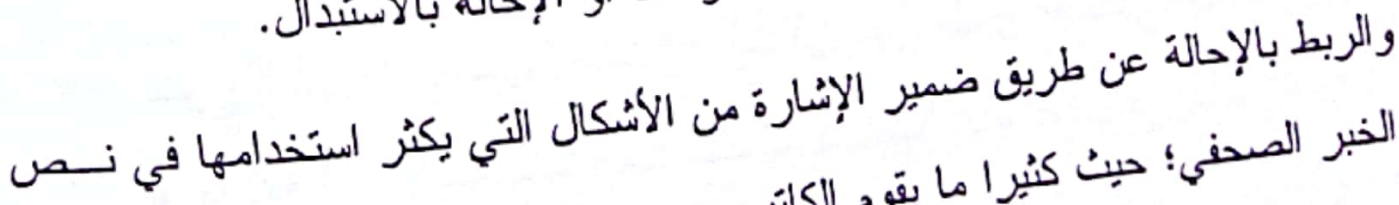

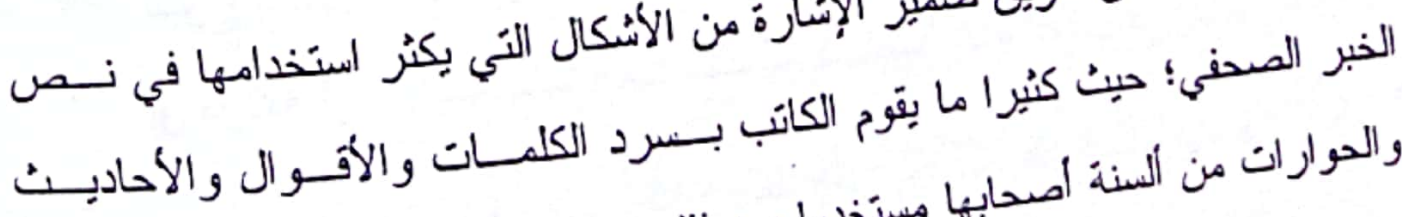

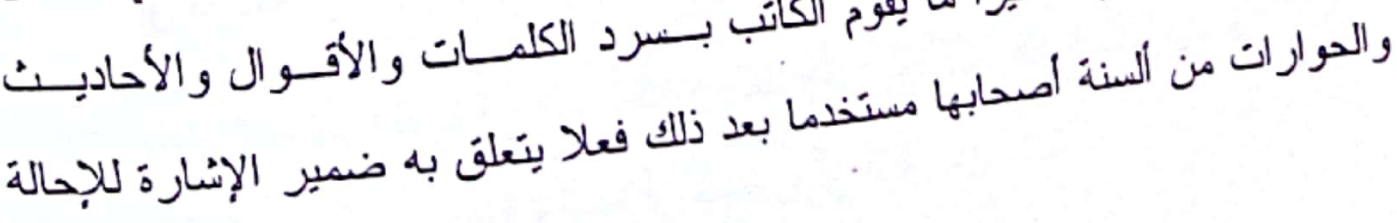




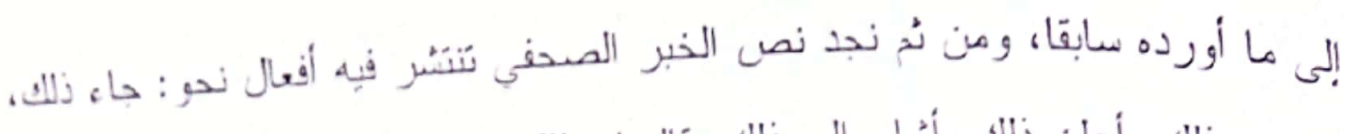

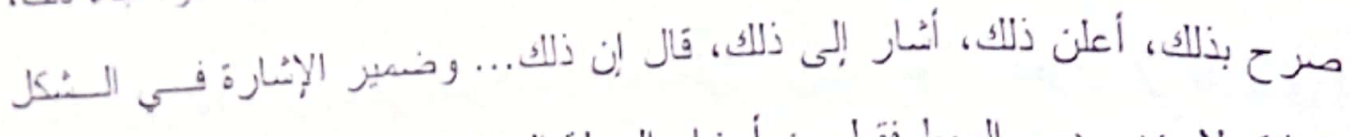

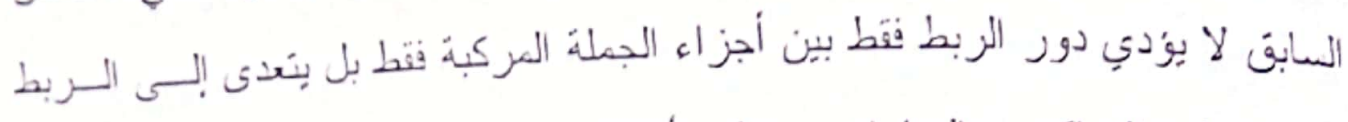

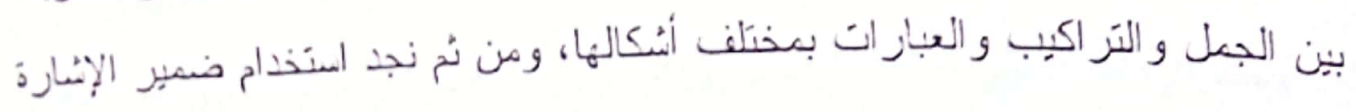

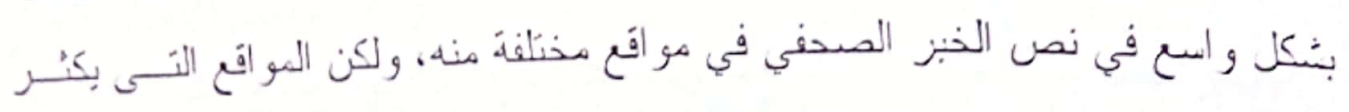

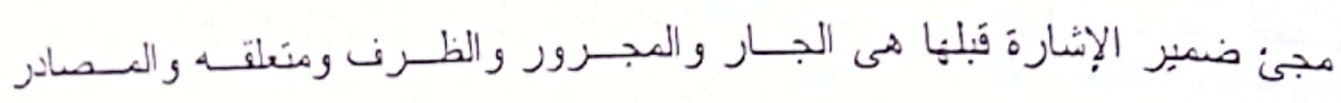

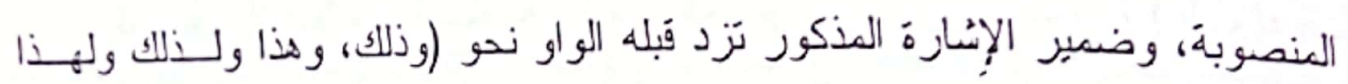
وبذلك... 20.

- و الربط بالإحالة عن طرين الإحالة بإعادة الذكر في الجملة الركبة قد يكون بإعـادة ذكر العنصر الإشاري كله أو بإعادة ذكر جزء منه. rا - تعنمد الجملة التركيبية في الربط بين طرفيها على وسيلتين ها الربط بـالأداة أو

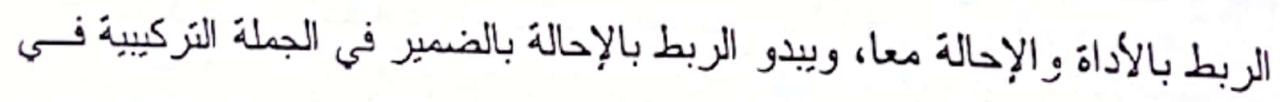
نص الذبر الصحفي عن طريق إلحاق العنصر الإحالي (الضمبر وإعـادة الـــكر)

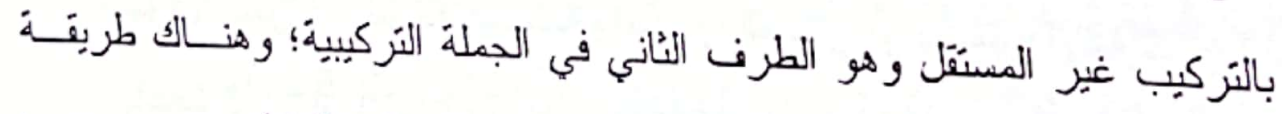

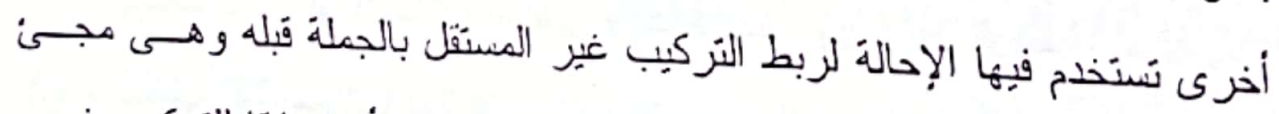

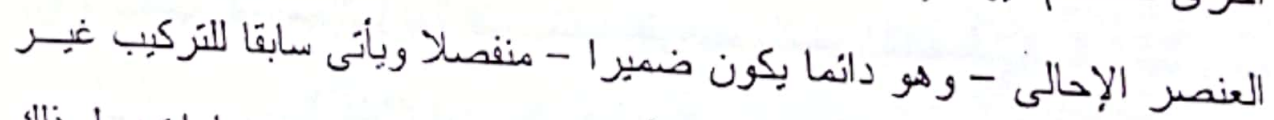

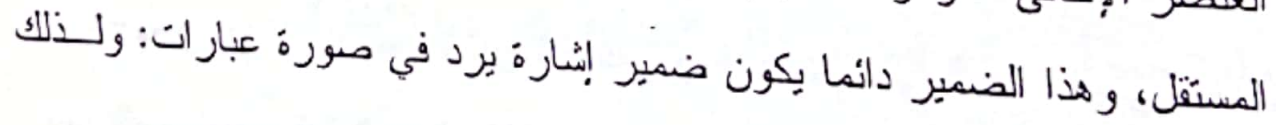
وبذلك ولهذا وهذا ولذا.

זا - تتمثل وسانل الربط بين اجزاء الفقرة في نص الخبر الصحفي في أربـع وسـانل ولن ولنا.

$$
\text { هى: }
$$

ب- - الربط بالأداة و الإحالة بالضمير -

ج- الربط بالاداة والإحالة بإعادة الأكر 
2- الزبط بالأداة و الإحالة بالضميز وإعادة الذكر.

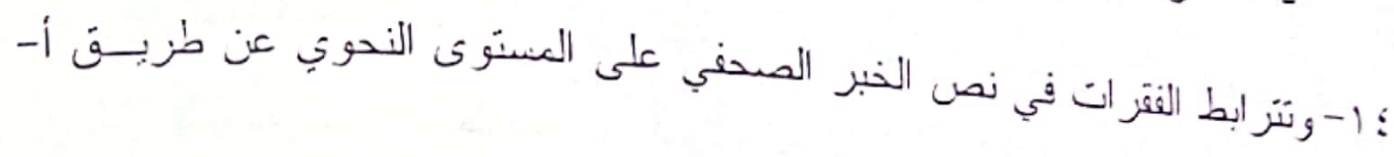

$$
\text { الإحالة ب- بألأداة }
$$$$
\text { ج- الأداة والإحالة. }
$$

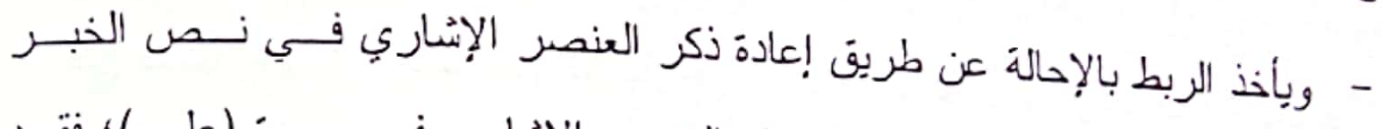

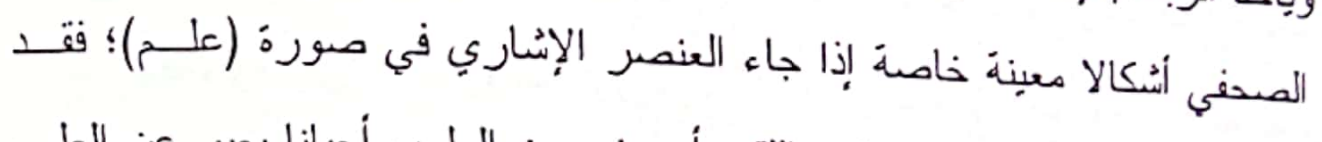

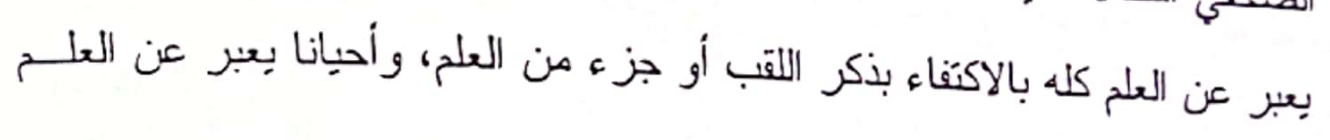
كله باللقب الوظني له.

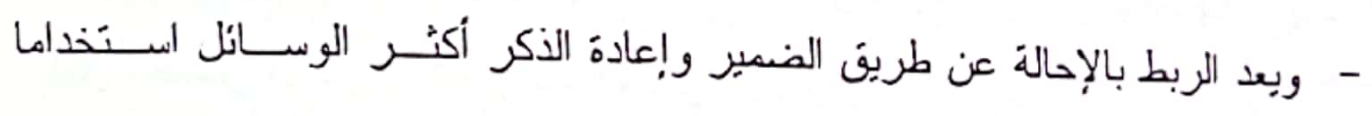
للربط بين الفتراتَفي نص الخبر الصحفى. - وترد البنية الإحالية في نص الخبر الصحفي غالبا في صورة وجود عنصر إبنارى

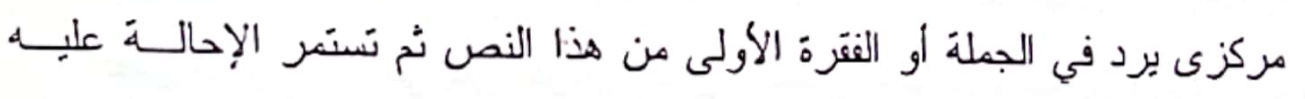

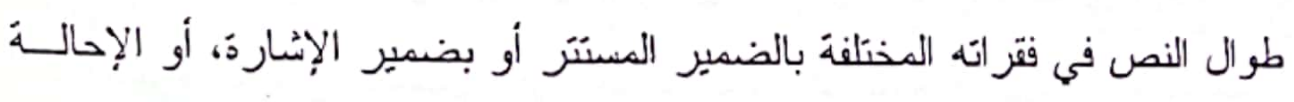

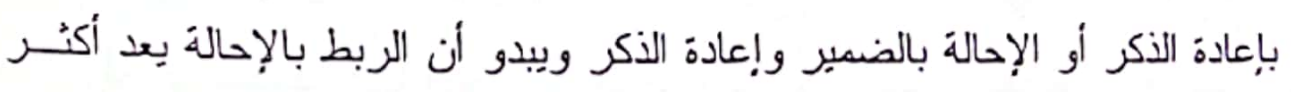
مناسبة للطبيعة السردية التى تُلب على نص الخبر النبر الصني. 10-بعبر عن زمن نص الخبر الصحفي ومكانه غالبا في الجملة الأولى منه باستخدام

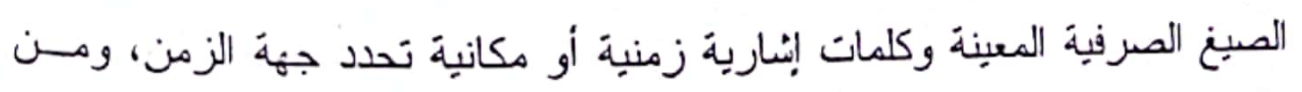

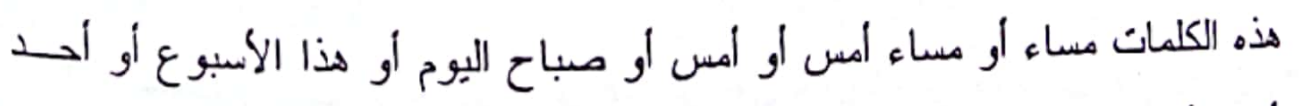
أيام الأسبوع... - ل ألمات - ممن سمات الإحالة الزمنية في نص الخبر الصحفي: 


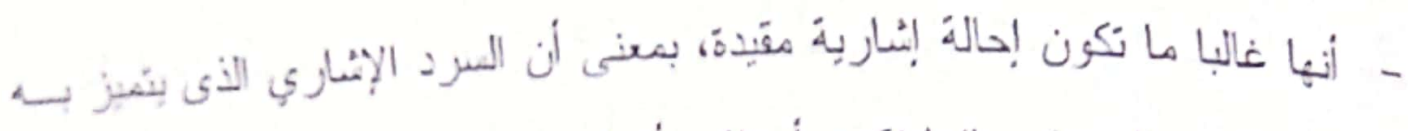

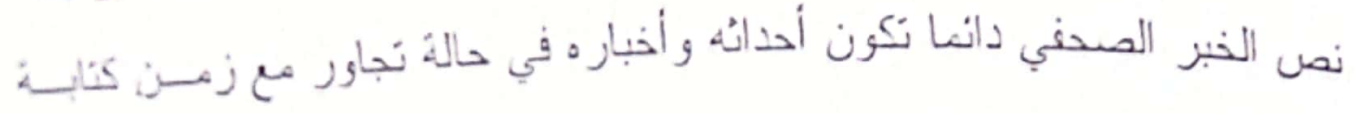

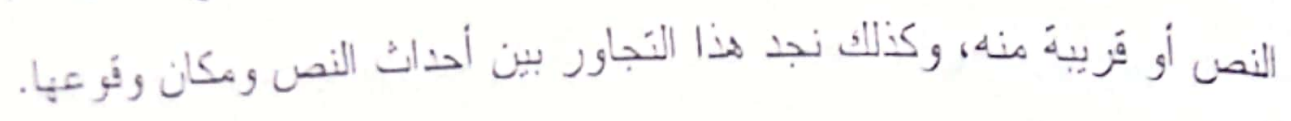

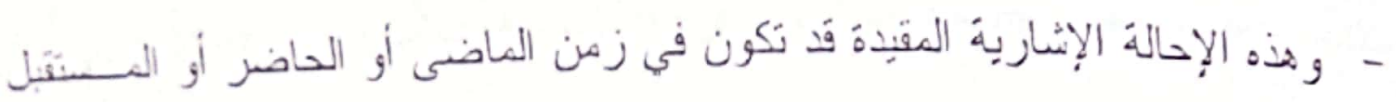

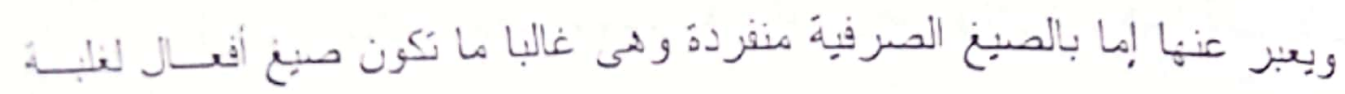

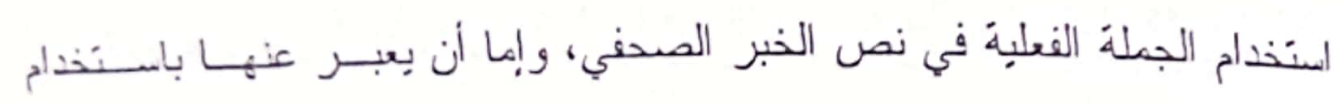

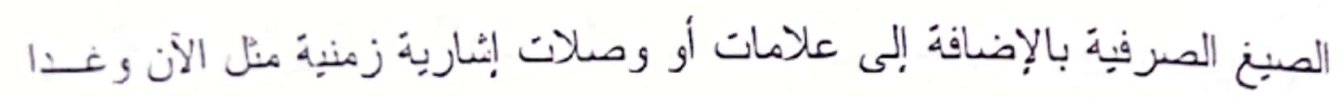 وأمس وصباح أمس ونهاية هذا العام... وهى التى تحدد وجهة الإحالة الزمنية.

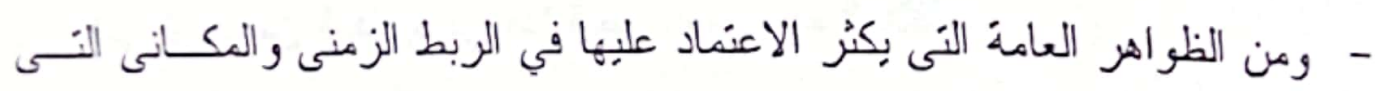 بتعبز بها نص الخبر الصحفي:}

- شيوع استعمال عبار ات إبارية زمنية أو مكانية تودي دور الربط الزمنى والكانى بين الجمل و التزر أكيب وكنللك بين الفقرات وتعل على نز ابط النص ونماسكه. - ومن أمثلة العبار ات الإنشارية الزمنية: (في الوفت نفسه) و (في هذا الصدد) و (فـي هذه الأنناء) و (في حبن) و (بعد ذلك) و (حتى الآن) و (منذ ذلك الحبن)...

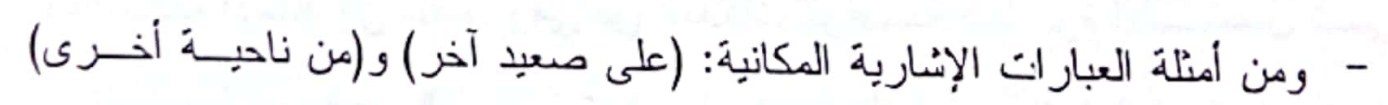
و (من جهة أخرى) و (من ثم) و (في المقابن) و (في هذا الإطار)...

17 الخبر الصحفي في تحقيق الترابط المعجى بين أجز انه. - مبقوم هذا التز ابط على أساس وجود تركيب محوري أساسى تمنه الجملة الأولـى

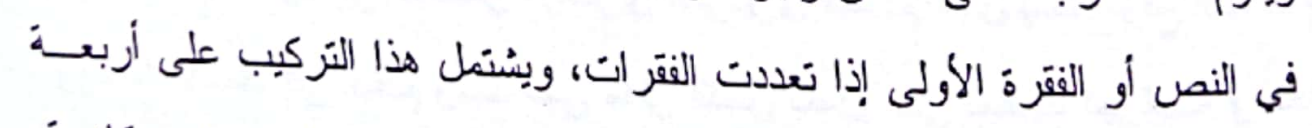

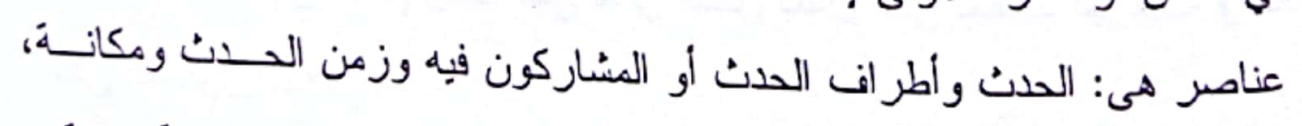

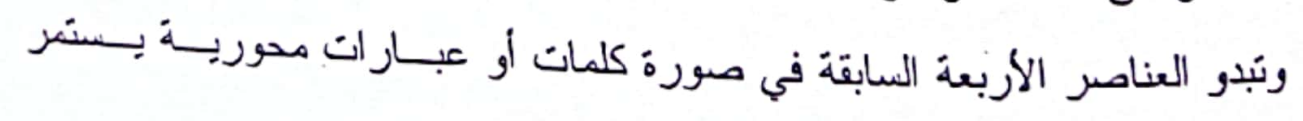




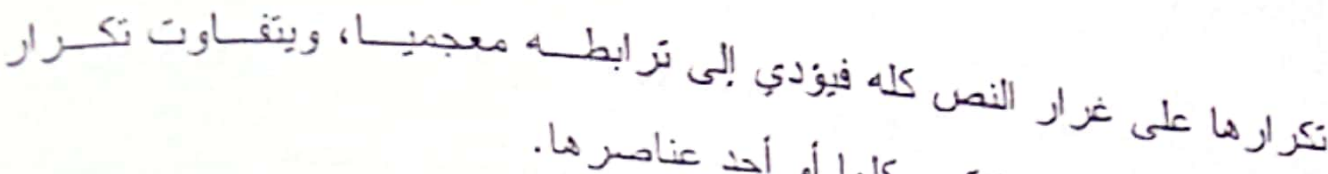

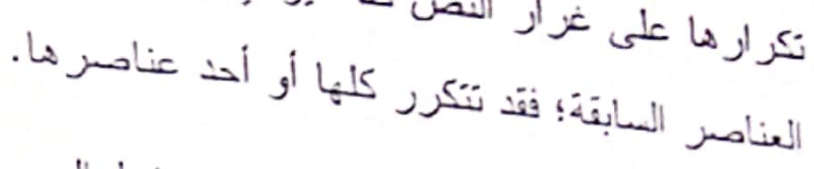

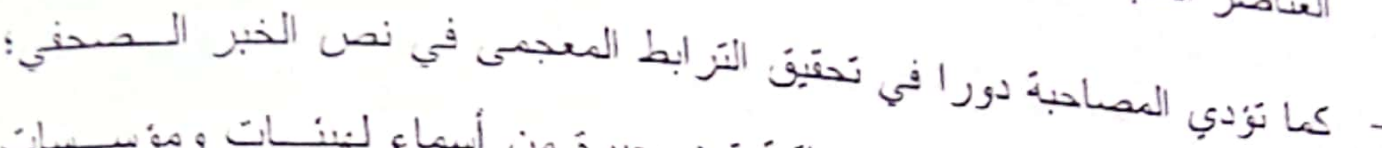

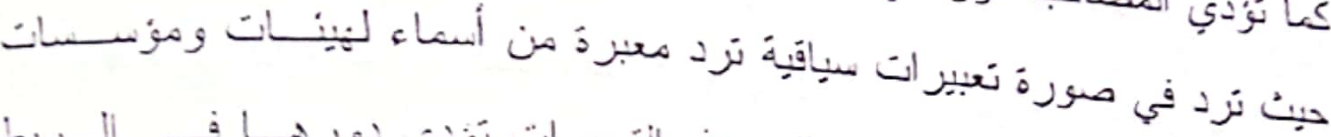

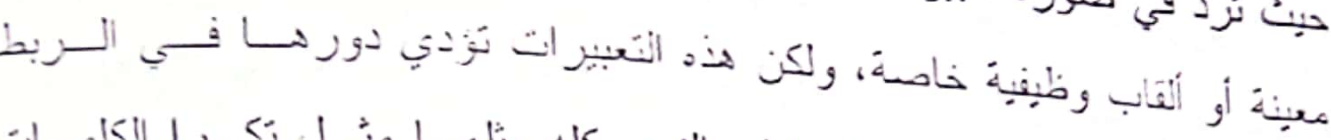

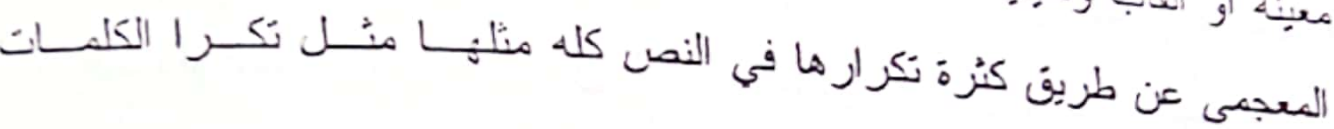
العدوريدة الني تؤدي الدور نفسه.

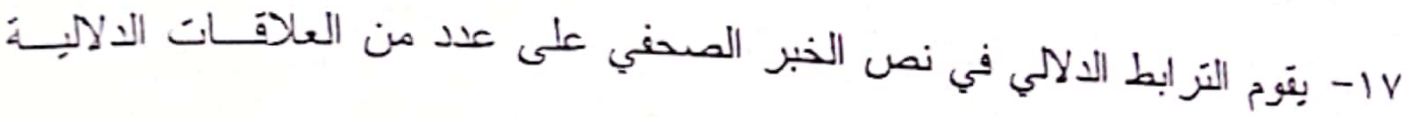
التى تربط بين العفاهيم في هذا النص، ومن هذه العلاقات: أ- علاقة الإجمال والتفصبل، وهى من أوضح العلاقات التي يمكن ملاحظتَها بسنيولة؛

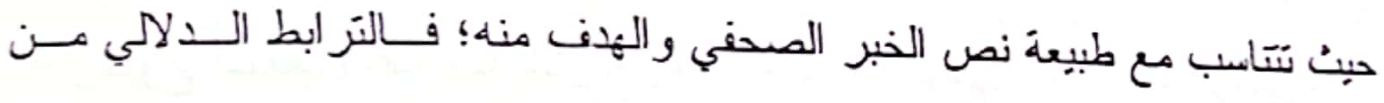

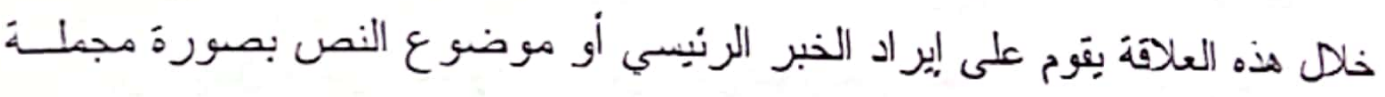

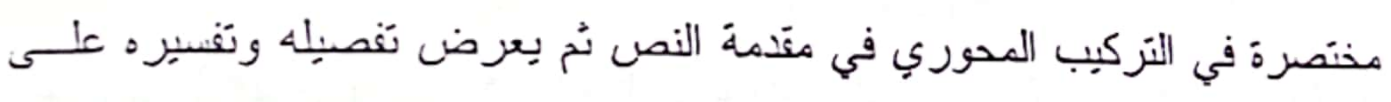

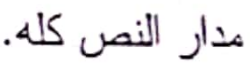

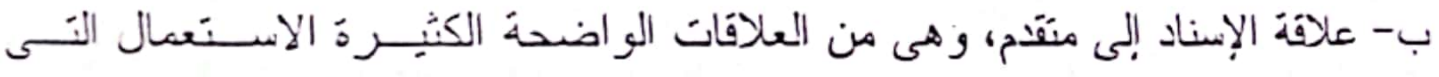
بنمبز بها نص الخبر الصحفي وتعل على تحتَفِ التعاسلك و التَر ابط الدلالي. وتقوم هذه العلاقة على أساس وجود عنصر إبتاري مركزى يعبر عنده في مقديسة

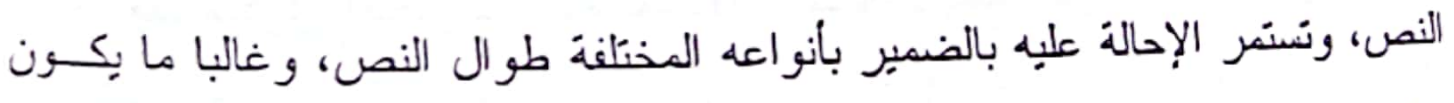

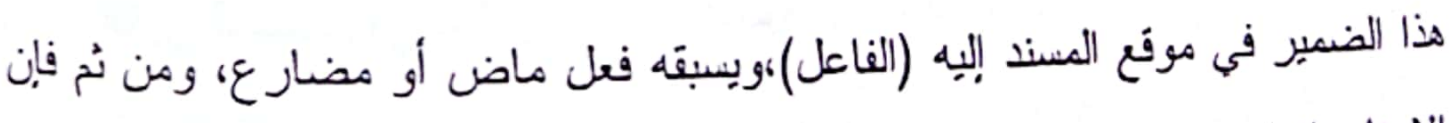

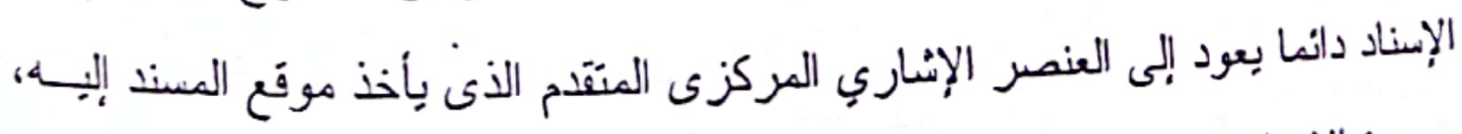

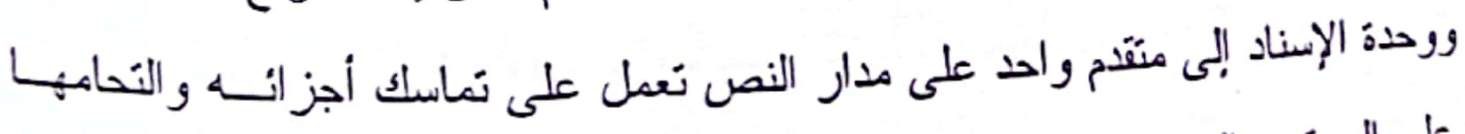
على المسنوي الدلالي. 
ج- علاقة السبب و النتيجة، ونزبط هذه العلاقة بين مكونات نص الخبر الصحفي مسن

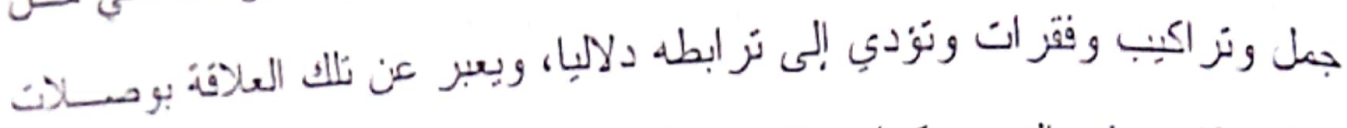

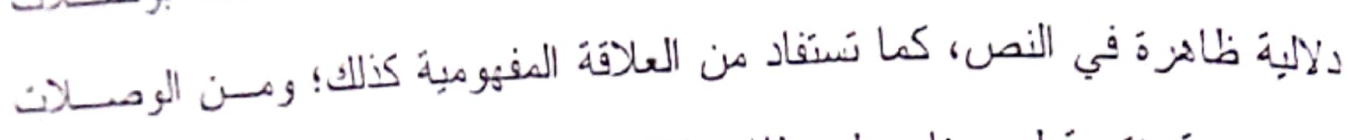

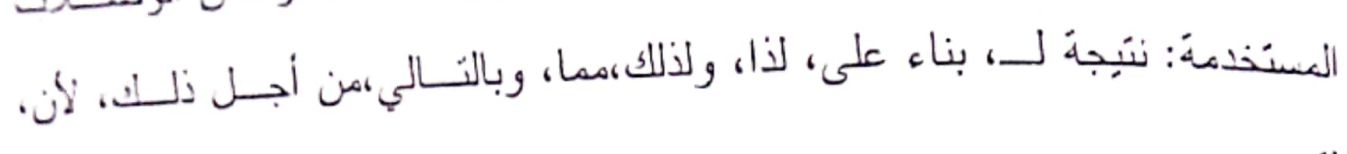
‥

د--علاقة النؤل و الجواب؛ وهى تَّوم على أن السؤال المطروح بحمل الدنث الرنبني

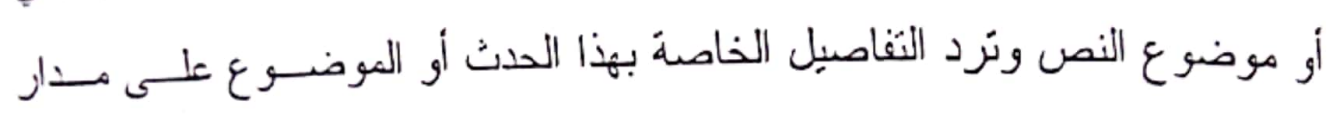
النص. 


\section{مصادر البيتب وهراجتبه}

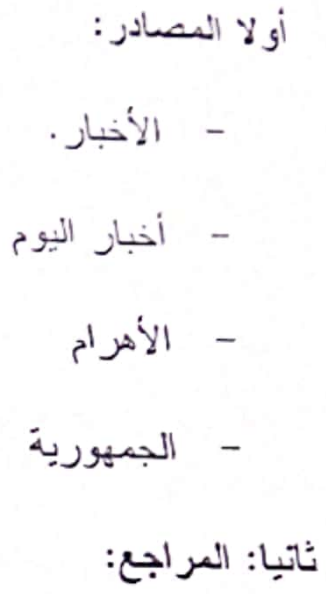

1- الدكتَر إبر اهيم أنيس: من أسرار اللغة - مكتبة الأنجلو المصرية.

r- برندشبلنر: علم اللغة والدر اسات الأدبية - ترجمة الاكتور محمود جاد الرب ت- الطبعـة

الأولى 19 19v- الدار الفنية للنشر و التوزيع.

r- ابن هشام: مغنى اللبيب عن كتب الأعاريب - تحفيق محمد محيى الدين عبد الحمبـد دار إحياء التز اث العربي.

$$
\begin{aligned}
& \text { ؟- ابن يعيث: شرح المفصل - مكتبة المتنبى - القاهرة. } \\
& \text { 0- - الدكتور نمام حسان: }
\end{aligned}
$$

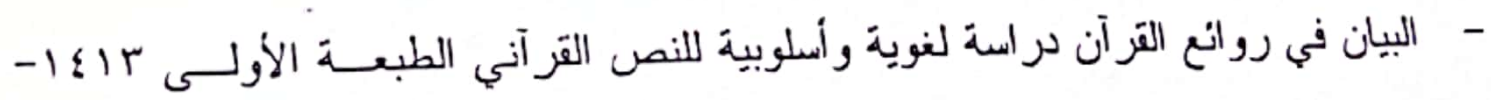
1991- الناشر عالم الكتب.

- اللغة العربية معناها ومبناها - الهينة المصرية العامة للكتاب rی19 1.

7- تَون ا. فان دايك - علم النص مدخل متذاخل الاختصاصان ترجمة الدكتور سعيد حسن

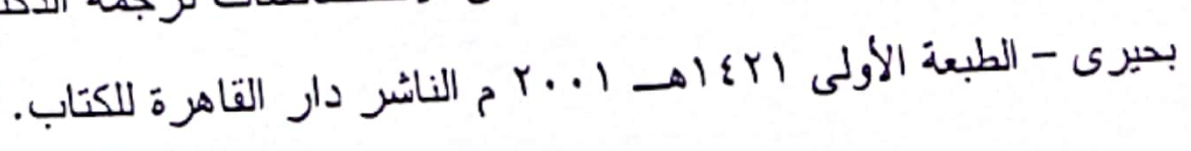




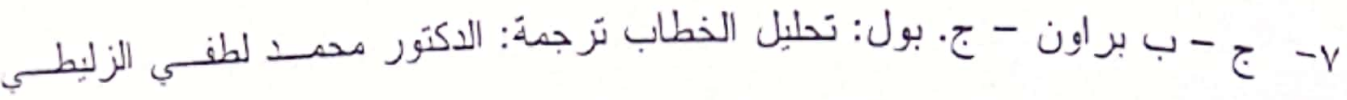

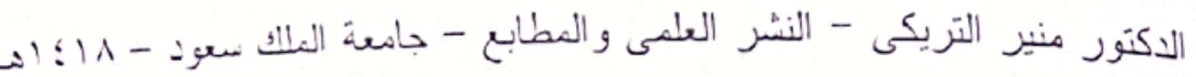
$.0199 \mathrm{~V}$

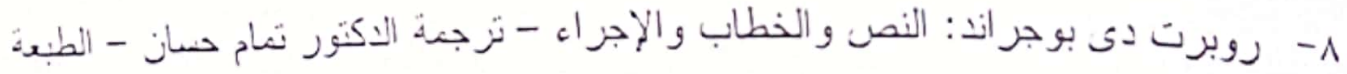

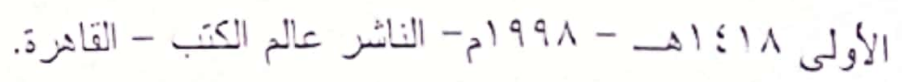

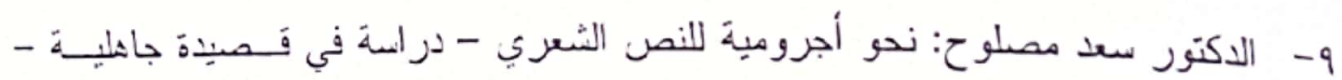

$$
\text { ـ الدجلة فصول العدد الأول - القاهرة: } 991 \text { ام. }
$$

- مراسات لغوية تطبيقِية في العلاقة بين البنية و الدلالة - الناشر مكتبة زهراء الثرق. - علم لغة النص المفاهيخ والاتجاهات - الطبعة الأولى ل149 - الشركة المصرية العالمية اللنشر لونجمان.

1 - السيوطي: همع الهو امع - عنى بنصديحه السبد محمد بدر الدين النـساني - الطبعة الأولى

r ا- عبد الش على مصطفي: الخو اص التركيبية للهجة النّارقة رسالة دكتـور اه - مخطــوط بكلية دار العلوم - جامعة القاهرة.

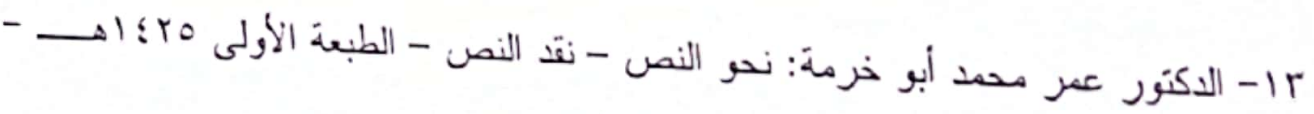

$$
\text { ؛. . بام - عالم الكتب الحديث - أربد - الأردن. }
$$

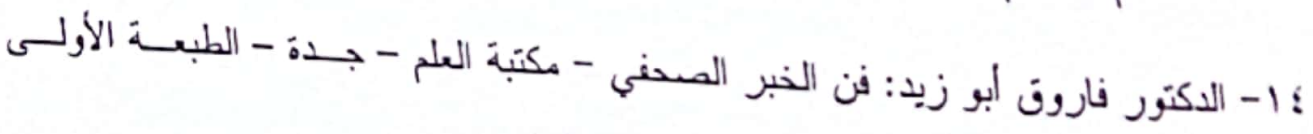

$$
.91911
$$

10 - فولنجانج هاينه مان - ويتر فيهنجر : مدخل إلى علم لغة النص - ترجمة الدكتور سعيد

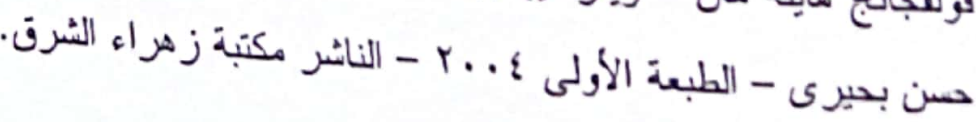

$$
\begin{aligned}
& 11 \text { - مجلة مجمع اللغة العربية بالقاهرة - المطبعة الأميرية. } \\
& \text { V ا - الدكتور محد حسن عبد العزيز: }
\end{aligned}
$$




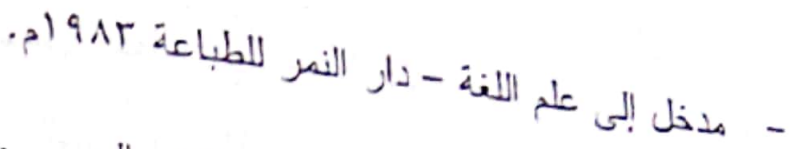

-

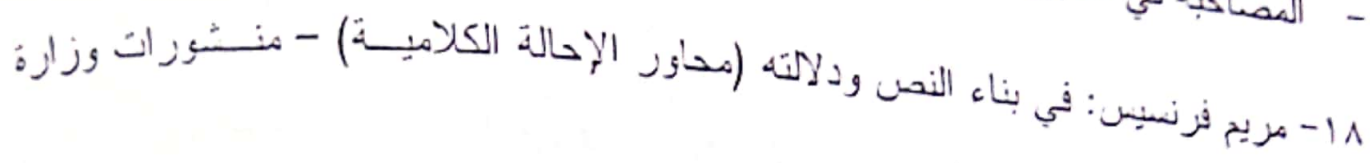

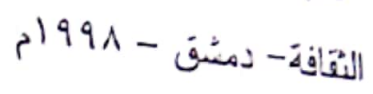

19- الاكتور منزى المخزومى: في الندو العزبي نقد وتوجيه - المكتبة العصربة - صبيزا -

بيزوت - الطبعة الأولى ؛ 197 ام.

. r- نايف خرما - على حجاج: اللغات الأجنبية تعليمها وتعلمها - الطبعة الأولـى 19 19 -

المجلس الوطنى للثقافة و الفنون - الكويت.

اب- هادى نهر: اللسانية والإعلام التأثير والتأنر - مركز التوثيق الإعلامى لــول الخلـيزج

العربي - بغداد 911 ام 